\title{
Reflexões sobre o ensino de psicologia em Escolas Técnicas Estaduais de São Paulo (versão corrigida)
}

Dissertação apresentada ao Instituto de Psicologia da Universidade de São Paulo para obtenção do título de Mestre em Psicologia.

Área de concentração: Psicologia Escolar e do Desenvolvimento Humano.

Orientadora: Profa. Dra. Marie Claire Sekkel. 
AUTORIZO A REPRODUÇÃO E DIVULGAÇÃO TOTAL OU PARCIAL DESTE TRABALHO, POR QUALQUER MEIO CONVENCIONAL OU ELETRÔNICO, PARA FINS DE ESTUDO E PESQUISA, DESDE QUE CITADA A FONTE.

Catalogação na publicação

Biblioteca Dante Moreira Leite

Instituto de Psicologia da Universidade de São Paulo

Pandita-Pereira, Angelina.

Reflexões sobre o ensino de psicologia em escolas técnicas estaduais de São Paulo / Angelina Pandita-Pereira; orientadora Marie Claire Sekkel. -- São Paulo, 2011.

$170 \mathrm{f}$.

Dissertação (Mestrado - Programa de PósGraduação em Psicologia. Área de Concentração: Psicologia Escolar e do Desenvolvimento Humano) Instituto de Psicologia da Universidade de São Paulo.

1. Ensino da Psicologia 2. Ensino profissional e técnico 3. Formação de professores 4. Ensino Médio I. Título. 
Nome: PANDITA-PEREIRA, Angelina

Título: Reflexões sobre o ensino de psicologia em Escolas Técnicas Estaduais de São Paulo.

Dissertação apresentada ao Instituto de Psicologia da Universidade de São Paulo para obtenção do título de Mestre em Psicologia.

Aprovado em:

Banca examinadora

Prof. Dr. Instituição:

Julgamento: Assinatura:

Prof. Dr. Instituição:

Julgamento: Assinatura:

Prof. Dr. Instituição:

Julgamento: Assinatura: 
Ao Daniel, pelo partilhar de experiências e do amor. 


\section{AGRADECIMENTOS}

À Profa. Dra. Marie Claire Sekkel, pela leitura do material, pelas perguntas e críticas estimulantes, pela orientação carinhosa. Por ser mais que minha orientadora, ensinou-me muito além do que pesquisar. Em convívio quase que diário, aprendi coisas importantes sobre a pós-graduação, sobre ser professor, sobre ser orientador. Sua conduta me fez pensar muito sobre mim mesma, sua calma e delicadeza contrastava com minha ansiedade e rigidez; isso me tornou mais humana e mais sensível ao outro.

Às Profas. Dras. Ângela Fátima Soligo e Marilene Proença Rebello de Souza, cujos questionamentos e apontamentos na banca de qualificação permitiram um salto de qualidade no trabalho aqui apresentado.

À escola técnica campo desta pesquisa, à sua equipe de direção, coordenação e professores e em especial ao docente e discentes das disciplinas observadas, que me receberam de braços abertos e estiveram sempre dispostos a responder minhas questões. Em especial a Vinícius ${ }^{1}$, pela generosidade com que me recebeu em suas salas de aula e sua disponibilidade para comigo durante 0 processo de pesquisa. Com estas condutas você conquistou meu respeito e admiração.

Aos meus pais, Waldelú de Fátima Pereira e Sônia Harumi Nakamura, que cada qual à sua maneira me proporcionaram o gosto por estudar e me impulsionaram a sempre superar meus limites.

À minha irmã Hana Cristina Pereira, pela descontração e leveza, seriedade e responsabilidade.

À minha irmã Ester Carolina Pereira, por abrir caminhos e por dar-me 0 melhor presente, minha sobrinha Naomi.

À minha irmã Maria Angélica Pereira, por ser companheira na vida, no compartilhar das indignações e nas lutas por um mundo mais justo.

À minha obatian Tiyoka Nakamura, cujo exemplo de pessoa, de ser humano, me inspira e relembra o quanto ainda preciso melhorar.

À minha sobrinha, Naomi Nakamura Tambasco, pela sapequice, doçura, curiosidade, que me proporcionou alguns dos momentos em que era possível me 
afastar completamente desta dissertação, para a ela voltar renovada. Por me trazer alegria, sempre.

À minha família, tios, tias, primos, primas, avôs e avós, cada um, a seu jeito, faz parte do que hoje eu sou.

Aos meus professores do ensino fundamental e médio, por me iniciarem no amor ao conhecimento. Em especial à Mirian Brisola de Oliveira Ferreira e Salete Dias.

Aos meus professores de graduação, com os quais aprendi as bases de muito do que hoje sei sobre Psicologia, e cuja proximidade e preocupação com seus discentes me marcaram, em muitos momentos confortaram e fizeram-me experenciar refletidamente que afeto e cognição estão muito relacionados. Que com suas teorias e questionamentos provocaram em mim transformações. Em especial: Salete Alberti, Ari Fernando Maia, Maria Regina Calvalcante, Ana Claudia Bortolozzi Maia, Jair Lopes Junior, Marisa Eugênia Melillo Meira, Alessandra de Andrade Lopes, Alessandra Turini Bolsoni Silva, Katsumasa Hoshino, José Gualberto Tuga Angerami.

Aos colegas do movimento estudantil da UNESP de Bauru, por partilharem as lutas por uma universidade e um mundo justo e por constantemente me levarem a questionar o processo de organização grupal, os aparentes consensos e ainda assim reafirmar o valor da coletividade.

Aos colegas de trabalho na Escola Estadual Professor Francisco Alves Brizola, funcionários da secretaria, da limpeza, da direção, da docência e da Diretoria de Ensino da região de Bauru. Foram cinco anos de convívio intenso, nos quais aprendi os prazeres e dissabores do contexto escolar, durante os quais eu me formei secretária e psicóloga. Sem vocês, nenhuma dessas formações teria sido tão enriquecida.

Aos colegas do NEPEl (Núcleo de Estudos e Pesquisas em Educação Infantil), com quem cresci teórica e pessoalmente, que ainda hoje continuam a me ensinar, por meio das minhas lembranças ou pela leitura de suas produções: Juliana Campregher Pasqualini, Marcelo Ubiali Ferracioli, Afonso Mancuso de Mesquita, Fábio Kawakami, Rafaela Gabani Trindade, Giselle Modé Magalhães e Taís Ribeiro Silva.

À Profa. Dra. Lígia Marcia Martins, com quem aprendi a fazer pesquisa e extensão, o valor do rigor teórico e do estudo aprofundado, em especial do 
Materialismo Histórico-Dialético, e cujo exemplo de docente e pesquisadora irá sempre me inspirar.

Ao Prof. Dr. Angelo Antônio Abrantes, em quem, além de professor, encontrei um amigo, com quem partilhar o dia a dia e os desafios e angústias da inserção interventiva numa escola. Que sempre acreditou que eu tinha potencial. Espero não desapontá-lo.

Aos amigos de graduação, Patrícia Ribeiro Martins, Aika Juliana Miyamura, Maria Flor Oliveira Conceição, Alekssey Marcos de Piero Sobral, Camila Nagai, Florêncio Mariano Costa Junior, Carolina Conde Newmann, Sabrina Henrique Bettiol, por fazerem da minha estada em Bauru um tempo feliz, pelas semelhanças e diferenças, pelas concordâncias e discordâncias teóricas e práticas, mas, acima de tudo, por serem amigos!

À Tais Ribeiro Silva, em memória, com quem tive o privilégio de partilhar a vida acadêmica e pessoal, que sempre foi para mim exemplo de força e delicadeza, que continua a me impulsionar a criar oportunidades de demonstrar meu afeto e carinho àqueles que amo. Saudades...

À Giselle Modé Magalhães, um agradecimento especial pela contribuição inestimável no diálogo e apontamentos críticos ao trabalho. Por encontrar brechas e produzir em um contexto hostil práticas transformadoras. E agradecimentos eternos pela parceria, cumplicidade e companheirismo, na vida acadêmica e especialmente na vida pessoal.

À Anne Midori Abe de Lima, pelo cuidado atento, o apoio necessário e a presença segura.

À Rafaela Albieri, pelo sorriso no rosto, a alegria de viver, a descontração e seriedade. Por partilhar as angústias de trabalhar na educação e torná-las sempre algo prazeroso.

À Maura Cristina Petrucelli Felipe, por ter me recebido em terapia e me auxiliado nos caminhos percorridos.

Aos colegas da Comissão Coordenadora do Curso de Licenciatura em Psicologia, pela acolhida e paciência, pelo carinho, pelas reflexões proporcionadas, por fazerem parte da minha história. Em especial: Profas. Dras. Ianni Regia Scarcelli, Patricia Izzar, Adriana Marcondes Machado, Marie Claire Sekkel, Leny Magalhães Mrech, Mirella Gualtieri, e Prof. Dr. Lineu Norio Kohatsu. 
Ao Prof. Dr. Lineu Norio Hokatsu e aos discentes da disciplina Política e Organização do Ensino de Psicologia nos anos de 2009 e 2010. Por constantemente questionarem a tudo e a todos e cujos debates e desconfianças ainda ressoam em meus pensamentos. Por me tirarem de meus lugares de aceitação e certeza.

Aos professores das disciplinas na pós-graduação, que me abriram um leque de possibilidades e introduziram-me a uma infinidade de temas e possibilidades de métodos até então desconhecidos para mim.

Aos colegas de orientação Lilian Caroline Urnau, Luis Fernando Saraiva, Marcia Regina Vital, Pollyana Cristiane de Melo, Bárbara Reze, Vitor Garcia Benossi, Livia Maria Andrade Malaquias, Daniela Viana Pannuti, Mariana Tavares Ferreira, pelo partilhar das angústias e felicidades, pelas discussões e reflexões, por constituírem um grupo e assim tornarem o processo na pós-graduação menos solitário.

Às colegas do alojamento eventual, em especial Laura Cristina Stobäus, pela companhia nos dias em São Paulo, pelo partilhar do afastamento de casa e de pessoas amadas, pelas conversas amenas, pela amizade em construção.

Ao meu amigo, companheiro, namorado, marido, Daniel Silva dos Santos, pelas opiniões sinceras e contribuições inestimáveis na leitura do material e construção do resumo em inglês desta dissertação. Pela paciência com minhas dúvidas e inúmeras crises com o trabalho. Mas especialmente pelos ombros reconfortantes nas horas difíceis, por ver em mim sempre algo melhor.

Aos funcionários da graduação, pós-graduação e biblioteca do Instituto de Psicologia da Universidade de São Paulo, pelos dias partilhados, pelas dúvidas sanadas, pelo apoio.

Ao CNPq (Conselho Nacional de Desenvolvimento Científico e Tecnológico), pelo apoio financeiro, sem o qual a dedicação necessária ao desenvolvimento deste trabalho não seria possível. 


\section{RESUMO}

PANDITA-PEREIRA, Angelina. Reflexões sobre o ensino de psicologia em Escolas Técnicas Estaduais de São Paulo. 2011. 170f. Dissertação (Mestrado) - Instituto de Psicologia, Universidade de São Paulo, São Paulo, 2011.

Esta dissertação é resultado de um processo que buscou conhecer e discutir as expressões e contribuições do ensino de psicologia no campo das Escolas Técnicas Estaduais de São Paulo (Etecs) tendo como fundamentação teórico-metodológica o Materialismo Histórico Dialético. No primeiro momento, realizou-se levantamento do campo de atuação possível para o licenciado em psicologia nas Etecs, obtendo- se que em número de discentes, diversidade de cursos e porcentagem de Etecs esse campo é amplo. Posteriormente, realizou-se pesquisa de campo em uma Escola Técnica Estadual de São Paulo envolvendo: observação de espaços comuns da escola e aulas de Psicologia Organizacional (curso de técnico em Administração) e Psicologia Social (curso de técnico em Marketing); análise de documentos; conversas informais e entrevista com 0 docente das disciplinas observadas. $O$ processo de análise partiu das questões construídas durante a pesquisa de campo e as significou a partir da teoria. Foi possível identificar a existência de processos potencialmente alienantes e processos potencialmente emancipatórios no ensino de psicologia, os quais são profundamente condicionados pela histórica subordinação da educação profissional às demandas ideológicas do mercado de trabalho e às condições de trabalho existentes nas Etecs, as quais entre outras questões restringem a autonomia dos docentes e os reduzem a técnicos. Compreendeu-se que há no ensino de psicologia das Etecs predominância dos processos potencialmente alienantes, os quais foram discutidos em termos de: 1 ) redução dos conhecimentos psicológicos ao uso instrumental; 2) marginalidade do conteúdo; 3) prescrição de formas de ser e agir; e 4) equívocos no ensino de conteúdos. Desvelou-se a existência de brechas que possibilitaram a existência de processos potencialmente emancipatórios, tais como: 1) relações de respeito mútuo; e 2) ensino de conhecimentos histórico-socialmente construídos. A pesquisa permite entrever as potencialidades do ensino de psicologia no campo das Etecs e afirmar a possibilidade deste contribuir para a formação humana emancipada, desde que: a) considere criticamente os condicionantes inerentes a seu próprio campo de conhecimento, atuação e formação de seus professores; e b) busque incessantemente superá-los. Para tal considerou-se como necessárias lutas no sentido da modificação de políticas públicas de educação e transformações na formação inicial e contínua dos professores de psicologia.

Palavras-chave: Ensino da Psicologia, Ensino profissional e técnico, Formação de professores, Ensino Médio. 


\begin{abstract}
PANDITA-PEREIRA, Angelina. Reflections on the teaching of psychology at state technical schools in São Paulo. 2011. 170f. Dissertação (Mestrado) - Instituto de Psicologia, Universidade de São Paulo, São Paulo, 2011.

This dissertation results of a process that aimed to discover and discuss the expressions and contributions of the teaching of psychology in the field of the technical schools of the state of São Paulo (Etecs), having as theoretical and methodological basis the historical and dialectical materialism. At first, the potential field for psychology teachers at the Etecs was surveyed, getting that, in number of students, diversity of courses and percentage of Etecs, this field is wide. Subsequent field research took place in an Etec, including: observation of the common areas of the school and of classes in Organizational Psychology (technical course in Business Administration) and Social Psychology (technical course in Marketing), analysis of documents; informal conversations and interviews with the teacher of the observed subjects. The process of analysis was built upon the issues raised during the field research and sought their meaning in theory. It was possible to identify the existence of potentially alienating processes and potentially emancipatory processes in the teaching of psychology, which are heavily affected by the historical subordination of vocational education to ideological demands of the labor market and by the working conditions existing in the Etecs which, among other issues, restrict the autonomy of teachers and reduce them to technicians. It was understood that there is, in the teaching of psychology in Etecs, prevalence of potentially alienating processes, which were discussed in terms of: 1) reduction of psychological knowledge to instrumental use, 2) marginality of contents, 3) prescription of ways of being and acting; and 4) mistakes in the teaching of contents. Was unveiled the existence of breaches that allowed the existence of potentially emancipatory processes, such as: 1) relations of mutual respect; and 2) teaching of historically and socially constructed knowledge. The research provides a glimpse of the potentialities of the teaching of psychology in the field of the Etecs and allows to affirm the possibility that it contributes to the emancipated human formation, provided that it: a) critically considers the inherent constraints to its own field of knowledge, its work and the formation of its teachers; and b) constantly seeks to overcome them. For this, struggles for the modification of public education policies and for changes in initial and continuing training of psychology teachers are necessary.
\end{abstract}

Keywords: Teaching of psychology, Career and technical education, Teacher education, Secondary Education. 


\section{LISTA DE TABELAS}

Tabela 1 - Resultado da revisão bibliográfica realizada por meio da ferramenta pesquisa integrada do Portal de Periódicos Capes, nas bases Psyclnfo, Scielo, Web of Science e SCOPUS.

Tabela 2 - Resultado da revisão bibliográfica realizada por meio da BVS-PSi. 50

Tabela 3 - Resultado da revisão bibliográfica realizada por meio da Biblioteca Digital de Teses e Dissertações Nacional.

Tabela 4 - Número de discentes por curso e classificação de acordo com os cursos que atendem maior número de discentes no conjunto das Etecs.

Tabela 5 - Número de Etecs por curso oferecido e número de disciplinas que o licenciado em Psicologia pode ministrar. 


\section{LISTA DE QUADROS}

Quadro 1 - Cursos e disciplinas das Etecs nos quais o licenciado em Psicologia pode ministrar aulas. 


\section{LISTA DE GRÁFICOS}

Gráfico 1 - Número e porcentagem de Etecs por cursos oferecidos.

68

Gráfico 2 - Perfil dos discentes da Etec campo desta pesquisa quanto a distribuição por faixa etária.

Gráfico 3 - Perfil dos discentes dos cursos técnicos de Administração e Marketing da Etec campo desta pesquisa quanto a situação do Ensino Médio propedêutico.

Gráfico 4 - Perfil dos discentes dos cursos técnicos de Administração e Marketing da Etec campo desta pesquisa quanto ao tipo de escola na qual cursam ou cursaram o Ensino Médio propedêutico.

Gráfico 5 - Perfil dos discentes dos cursos técnicos de Administração e Marketing da Etec campo desta pesquisa quanto ao tipo de escola pública na qual cursam ou cursaram o Ensino Médio propedêutico. 


\section{LISTA DE SIGLAS}

ABEP

ABNT

BID

BVS-PSI

CENP

CETEC

CEU

CFP

$\mathrm{CNI}$

$\mathrm{CNPq}$

CONAE

CRP-SP

ENEM

Etecs

EUA

FENPB

FMI

FUNDAP

$\mathrm{HC}$

LDB

NEPEI

PEQ

$P U C$ - SP

SENAC

SENAI

SESC

SESI

SinPsi

SUS

UERJ

Unicamp

USP
Associação Brasileira do Ensino de Psicologia

Associação Brasileira de Normas Técnicas

Banco Interamericano de Desenvolvimento

Biblioteca Virtual em Saúde - Psicologia

Coordenadoria de Estudos e Normas Pedagógicas

Unidade de Ensino Médio e Técnico

Centro Educacional Unificado

Conselho Federal de Psicologia

Confederação Nacional da Indústria

Conselho Nacional de Desenvolvimento Científico e Tecnológico

Conferência Nacional de Educação

Conselho Regional de Psicologia de São Paulo

Exame Nacional do Ensino Médio

Escolas Técnicas Estaduais de São Paulo

Estados Unidos da América

Fórum de Entidades Nacionais da Psicologia Brasileira

Fundo Monetário Internacional

Fundação do Desenvolvimento Administrativo

Hospital das Clínicas

Lei de Diretrizes e Bases da Educação Nacional

Núcleo de Estudos e Pesquisas em Educação Infantil

Programa Estadual de Qualificação Profissional

Pontifícia Universidade Católica - São Paulo

Serviço Nacional de Aprendizagem Comercial

Serviço Nacional de Aprendizagem Industrial

Serviço Social do Comércio

Serviço Social da Indústria

Sindicato dos Psicólogos do estado de São Paulo

Sistema Único de Saúde

Universidade do Estado do Rio de Janeiro

Universidade Estadual de Campinas

Universidade de São Paulo 


\section{SUMÁRIO}

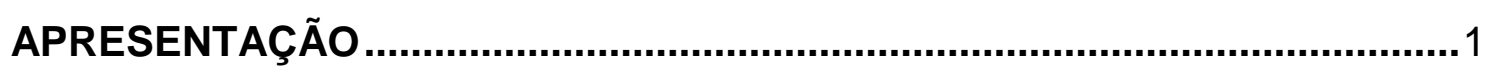

INTRODUÇÃO....................................................................................

1. EdUCAÇÃo PROFISSIONAL TÉCNICA dE NíVEL MÉdIO NO BRASIL: UMA COMPREENSÃO POSSÍVEL A PARTIR DA HISTÓRIA

1.1. Esclarecimentos preliminares: dos objetivos e concepções que orientaram a confecção do capítulo

1.2. Da educação profissional técnica de nível médio: considerações iniciais

1.3. História da educação profissional técnica de nível médio no Brasil

1.4. Particularidades da educação profissional técnica de nível médio no estado de São Paulo

2. O ENSINO DE PSICOLOGIA NA EDUCAÇÃO PROFISSIONAL TÉCNICA DE NÍVEL MÉDIO

2.1. Esclarecimentos preliminares: dos objetivos e concepções que orientaram a confecção do capítulo

2.2. Breve contextualização do ensino de psicologia na educação profissional técnica de nível médio 39

2.3. Busca por contribuições a partir da revisão bibliográfica 47

2.4. Panorama atual .55

2.4.1. Etecs, cursos e disciplinas nos quais o licenciado em Psicologia pode ministrar aulas ................................................58

3. MÉTODO 69

3.1. Esclarecimentos preliminares: dos objetivos e concepções que orientaram a construção do método 69

3.2. Pressupostos epistêmico-metodológicos e características do tema de estudo

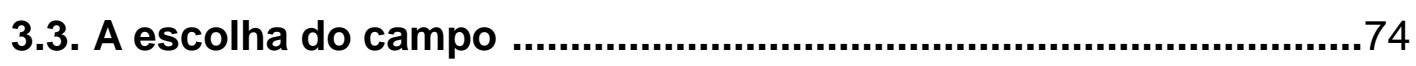

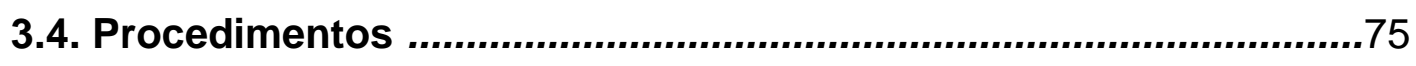

3.4.1. Observações em aula e dos espaços comuns da escola ..........75

3.4.2. Análise de documentos .......................................................79 
3.4.3. Conversas informais e conversa formal .80

3.4.4. Processo de pesquisa e análise que perpassa o conjunto de procedimentos elencados .82

3.5. Caracterização do campo desta pesquisa 84

3.5.1. A Etec .84

3.5.2. Os discentes .88

3.5.3. O docente 92

4. PROCESSOS POTENCIALMENTE ALIENANTES E EMANCIPATÓRIOS: EXPRESSÕES E CONTRIBUIÇÕES DO ENSINO DE PSICOLOGIA NAS ETECS 94

4.1. Esclarecimentos preliminares 94

4.2. Condições de trabalho .98

4.2.1. Psicologia Organizacional 104

4.2.2. Psicologia Social 107

4.3. Processos potencialmente alienantes: Expressões e contribuições do ensino de psicologia nas Etecs .109

4.3.1. Redução dos conhecimentos psicológicos ao uso instrumental 109

4.3.2. Marginalidade do conteúdo 114

4.3.3. Prescrição de formas de ser e agir 117

4.3.4. Equívocos no ensino de conteúdos .124

4.4. Processos potencialmente emancipatórios: Expressões e contribuições do ensino de psicologia nas Etecs 129

4.4.1. Relações de respeito mútuo 129

4.4.2. Ensino de conhecimentos histórico-socialmente construídos

5. CONSIDERAÇÕES FINAIS

REFERÊNCIAS

APÊNDICE A - Quadros contendo autor, título, classificação e referência dos artigos encontrados por meio da revisão bibliográfica .159

APÊNDICE B - Quadro contendo cursos atualmente oferecidos nas Etecs, número de discentes e disciplinas que podem ser ministradas pelo licenciado em Psicologia por curso. 165

APÊNDICE C - Carta de autorização para a realização da pesquisa 
APÊNDICE D - Termo de consentimento livre e esclarecido .........................168 ANEXO A - Matriz curricular do curso de técnico em Administração .............169 ANEXO B - Matriz curricular do curso de técnico em Marketing ..................170 


\section{APRESENTAÇÃO}

Por que estudar ensino de psicologia em escolas técnicas? Inúmeras vezes me fiz esta pergunta no decorrer do primeiro ano do mestrado. Isso porque, ao ingressar na pós-graduação, meu tema de pesquisa era outro, e meu interesse focava-se na relação entre três campos: políticas públicas, psicologia e formação de educadores. As perguntas e delimitações dos dois temas de pesquisa (inicial e atual) foram se transformando a cada aula, cada disciplina, cada texto, adquirindo contornos enriquecidos por esses espaços.

Permitam-me fazer uma digressão, me afastar um pouco do tema desta dissertação, e tentar aproximar o leitor dos meus interesses iniciais ao ingressar no mestrado. Entendo que tal percurso auxiliará a mim e ao leitor na compreensão das opções de enfoque - teóricas e metodológicas - escolhidas para permear esta dissertação.

Primeiro havia o interesse pela educação e suas potencialidades em relação ao desenvolvimento humano. Talvez devido ao incentivo à leitura desde muito pequena por minha mãe e irmãs, ao estudo em escolas públicas com boa parte do coletivo de profissionais comprometido e incentivador do meu desenvolvimento e aos vínculos formados com colegas de turma e profissionais da escola. A escola constituiu-se, para mim, em um lugar de proteção, liberdade e felicidade, um lugar prazeroso de se estar, em contraste ao período em que não estava ali, de trabalho e situações difíceis. Assim, no cenário tão desolador da escola pública - que vemos nos jornais, estatísticas oficiais e mesmo em algumas pesquisas acadêmicas minha experiência singular apontava que era possível dentro de tantos limites ter experiências formativas e humanizadoras na escola. Mesmo que o contexto que permeou meus anos de escolarização tenha mudado, sigo crendo ser possível que a escola (cada qual em sua singularidade) possa proporcionar a outros experiências positivas como as que tive. Creio que esta pitada de otimismo, aliada a análises críticas proporcionadas pelos anos de formação escolar, far-se-á presente em meu texto.

O interesse pela educação encontrou-se com a Psicologia já no Ensino Médio. A frequência às aulas de psicologia e o contato com a professora em outros espaços me proporcionou a compreensão de que a psicologia tinha algo a dizer e contribuir em relação ao desenvolvimento humano. 
Ao final do primeiro ano da faculdade, tive a oportunidade de ouvir uma palestra na qual Flavia Asbahr falou com muita propriedade e paixão sobre seu trabalho, dos conflitos e possibilidades produzidos no encontro da psicologia com a educação, da mesma com um determinado grupo de professores. Naquele dia eu me apaixonei pela área e, no decorrer da minha formação, optei refletida e teoricamente por ela e pelo trabalho com educadores.

Alguns anos depois comecei a trabalhar como secretária de uma escola pública estadual de ensino fundamental e médio, experiência que a princípio foi muito dolorosa e opressora para quem, por conta da formação, estava mais sensível às contradições do espaço escolar, e que ali se manifestavam para mim de uma forma muito dura (escola grande, com a aparência de uma prisão, percebendo as constantes "visitas de alunos problemas" na sala da direção, os quais eram recebidos com discursos pouco acolhedores ou emancipatórios). Porém, no decorrer dos cinco anos que ali permaneci, vivenciei o que chamo de um certo luto pela morte da escola idealizada, das expectativas inalcançáveis, de um horizonte normativo de como a escola deveria ser. Pude aos poucos me aproximar do que essa escola era, experienciando a escola e apropriando-me dela por uma nova perspectiva, imersa em sua teia de relações, e buscando ao mesmo tempo um distanciamento crítico, vendo relações tão preciosas se produzirem e ao mesmo tempo processos de inclusão marginal se evidenciarem. Escola real! Escola que me ensinou que é preciso vivenciar o espaço e refletir sobre o mesmo para conhecê-lo. Escola que me instigava a participar de espaços de formação que me ajudassem a refletir as questões que ali vivia tão intensamente. Acho que tudo isso poderá ser visto no texto, nas escolhas metodológicas e nas considerações sobre o que pude aprender com esta pesquisa.

Quanto ao tema das políticas públicas, não sei precisar como me encontrei com ele. Posso dizer apenas que desde o ensino fundamental até a faculdade participei ativamente do movimento estudantil, e que este espaço foi fundamental para a minha formação, com suas contradições, conflitos, discussões e reflexões. Orientou ainda meu olhar sobre as disputas de poder e sobre o contexto social, político, econômico, os quais impõem limites e possibilidades à educação, bem como à profissão de psicólogo. Tais aspectos também estão presentes nesta dissertação. 
Digressão feita, retornemos ao tema desta pesquisa. Como me aproximei do ensino de psicologia no ensino médio?

Tive a oportunidade de ter a disciplina de psicologia no ensino médio e cursei a licenciatura em Psicologia, mas não era sensível ao tema a ponto de ter motivação para pesquisá-lo.

Ao ingressar no mestrado a Profa. Dra. Marie Claire Sekkel (minha orientadora), bastante engajada na reestruturação do curso de licenciatura do Instituto de Psicologia, perguntou da minha formação, das minhas experiências. Ao saber que eu tinha licenciatura e experiência de trabalho em escola de educação básica, comentou que haveria um processo seletivo para um monitor da licenciatura e que eu tinha os requisitos para concorrer à função.

Concorri, fui selecionada e iniciei o trabalho como monitora da licenciatura em Psicologia. Uma das minhas funções era fazer a mediação das relações entre a universidade e as escolas onde os estudantes realizariam seus estágios. Porém, na rede pública estadual de ensino propedêutico, não havia mais a disciplina de psicologia. Ao mesmo tempo, as disciplinas de estágio em escolas ainda não estavam sendo oferecidas. Uma das minhas primeiras atribuições foi então levantar quais seriam os possíveis campos de estágio para os estudantes que viessem a cursar a licenciatura. Uma demanda prática, a partir da qual me deparei com a amplidão de possibilidades de campos de estágio para o licenciando em Psicologia nas Escolas Técnicas Estaduais de São Paulo (Etecs). Essa descoberta me deixou um questionamento: por que dentro de uma mesma política estadual a psicologia é abolida do ensino propedêutico e se mantém no ensino técnico?

Timidamente fui buscando entender tanto as questões que envolvem o ensino de psicologia quanto as que envolvem as escolas técnicas - área da qual eu nada entendia. Ao fazê-lo fui buscando sentidos pessoais que justificassem tanto a escolha desse tema para minha pesquisa, quanto o abandono, ao menos temporário, do tema que motivou meu ingresso no mestrado.

Não foi uma decisão fácil, pois se o novo tema me instigava, me desafiava, ao mesmo tempo me amedrontava, visto serem poucas produções que o discutem, e pouco o meu conhecimento sobre o mesmo. Havia ainda uma vinculação afetiva muito forte com meu tema inicial, reflexões já sistematizadas, autores a quem eu sabia que poderia recorrer. Hoje vejo que optei por um não abandono completo, pois se não falarei mais das contribuições da psicologia para formação de educadores, 
em certa medida buscarei falar dos desafios da formação de educadores de psicologia e das contribuições do ensino de psicologia no nível médio. Permanece o viés das políticas públicas, antes voltadas à formação de educadores, hoje ao ensino médio profissional. As questões que envolvem educação, como podem ver, não saíram de cena.

Meu primeiro olhar para a questão era orientado por um preconceito em relação às escolas técnicas - ligando-as tão somente a um ensino orientado por um paradigma taylorista-fordista de mera adequação do indivíduo às demandas do setor produtivo - e por um horizonte normativo de que a educação deveria se dar no ensino propedêutico. Como se vê, eu não estava alheia às determinações do meu tempo e de meu ambiente social, que valoriza muito mais o trabalho intelectual que o trabalho manual, as atividades de planejamento às de execução.

Os estudos sobre escola técnica e propedêutica foram me instigando a pensar de forma diferenciada, complexificando e ressiginificando meus questionamentos frente ao que hoje compreendo em relação à educação profissional técnica de nível médio - especialmente no que diz respeito às Etecs - e o que a mesma expressa do contexto social e histórico.

Progressivamente compreendi meu total desconhecimento e ignorância em relação ao ensino profissional, ao ensino de psicologia neste campo, e fui construindo a pergunta: Quais as contribuições do ensino de psicologia no campo das Etecs?

A postura adotada nesta dissertação será de conhecer e discutir que lugar é este ocupado pela psicologia no ensino técnico; de pensar as possíveis contribuições do ensino de psicologia à formação de docentes e discentes enquanto indivíduos e enquanto profissionais; de explorar este campo carente de pesquisas e reflexões, partindo de um lugar de desconhecimento e abertura para compreender as relações entre psicologia e formação profissional que se fazem possíveis no espaço da educação média. Convido o leitor a permanecer comigo nesta jornada que construirei a seguir. 


\section{INTRODUÇÃO}

Os conhecimentos psicológicos estão presentes no ensino de nível médio brasileiro desde a primeira iniciativa pública de seu provimento, por volta de 1830, antes de a psicologia se constituir como ciência independente (MASSIMI, 1993). Este ensino era composto pela modalidade propedêutica ${ }^{2}$, a qual foi historicamente destinada a uma formação que nega seu vínculo com a realidade e com saberes práticos (CASTANHO, 2007; CURY, 1998; KUENZER, 2005).

Quando o ensino médio profissional começou a ser oferecido pelo poder público e passou de uma educação com fins de moralização pelo trabalho para uma educação de formação profissional, responsável pelo ensino de saberes práticos requeridos para o exercício de uma determinada profissão (CASTANHO, 2007; CURY, 1998; KUENZER, 2005; SCHWARTZMAN; BOMENY; COSTA, 1984), O ensino de psicologia ganhou espaço também nos cursos técnicos ligados às áreas de saúde, direito e relações humanas (SOLIGO; AZZI, 2009).

Como se pode entrever pelos parágrafos anteriores, há no ensino de nível médio brasileiro duas modalidades educacionais, a propedêutica e a profissional, e estas têm objetivos bastante distintos, os quais, como veremos, são decorrentes da divisão social do trabalho e desigualdade de classes.

Com as transformações em curso no mundo do trabalho (que buscam maior flexibilização dos processos produtivos), aliadas a uma ideologia que associa possibilidades de emprego à formação acadêmica e a características de personalidade, a educação, em especial a profissional, vem se modificando, incluindo conteúdos de uma formação geral com fins de produção de uma subjetividade disciplinada a este contexto (FERRETI; SILVA JÚNIOR, 2000; FRIGOTTO; CIAVATTA, 2006a; MORAES, 2002b; OLIVEIRA, R. 2002).

É em meio a tal dualidade e transformações que o ensino de Psicologia historicamente se fez presente, tanto na modalidade propedêutica quanto na profissional, fosse como disciplina obrigatória, optativa ou como conteúdo abrangido por outras disciplinas. Mas, quais contribuições os conhecimentos psicológicos traziam nessas diferentes modalidades de ensino?

Não há informações quanto a isto na modalidade profissional. Já na

2 Esta denominação remete aos primórdios do ensino propedêutico, o qual tinha por objetivo a preparação para os exames de ingresso no nível superior. 
modalidade propedêutica, as poucas pesquisas que se dedicaram ao tema (DADICO, 2009; LEITE, 2007; MRECH, 2001, 2007) apresentam um quadro desolador, de uma psicologia burocratizada, superficial, a-histórica e que por vezes se confundia com psicologia clínica, escolar ou de orientação profissional.

Muitas questões convergiam para que a psicologia se expressasse dessa forma, e penso que uma questão especial era a de que não havia clareza sobre o que ensinar para estudantes do nível médio. Falta de clareza esta que parece persistir quando se trata do ensino de conhecimentos psicológicos no ensino técnico pois, como já dito acima, não há produções que o discutam.

No entanto, como apresentarei ao longo desta dissertação, os conhecimentos psicológicos estão presentes no ensino técnico, e há uma luta para que o ensino de psicologia esteja presente no ensino médio propedêutico. Como então construir uma proposta de ensino de Psicologia, seja para a modalidade propedêutica, seja para a modalidade profissional, que possa ter significado e sentido associados ${ }^{3}$, no sentido atribuído por Leontiev (1978) a estes conceitos?

Para esse autor os significados são supraindividuais, representam as maneiras pelos quais os homens assimilam a experiência humana e referem-se às finalidades humanas próprias de cada atividade. Já os sentidos são constituídos pela conversão das objetivações, por um determinado indivíduo, em reflexos psíquicos que influam na vida deste e em sua relação com o mundo. O sentido é subjetivo sem, no entanto, perder sua objetividade, pois é dado a partir de um caráter social mais geral e adquire conotação singular, resultante da interação ativa entre indivíduo e mundo. O significado é social, objetivo, sem no entanto perder sua subjetividade, pois é construído na interação entre subjetividades e o mundo. Ao utilizar esses dois conceitos, quero marcar que a proposta de um ensino de psicologia precisa ter ao mesmo tempo significado - ultrapassando os muros da escola, servindo à compreensão e transformação social, vertendo seus conhecimentos à finalidades humanas - e um sentido pessoal ao estudante que a ela tiver acesso, auxiliando-o a compreender aquilo que o constitui.

Penso que para construir uma proposta de ensino de psicologia que tenha tais características, é preciso momentaneamente distanciar o olhar da psicologia e voltá-lo a quem este conhecimento seria dirigido. Quem é este estudante? Em que

3 Conforme veremos no item 4, na sociedade atual significado e sentido encontram-se dissociados, sendo este seu estranhamento uma das expressões da alienação. 
contexto se encontra inserido? Que conteúdos farão sentido em sua formação? Que conteúdos terão potencial de transformação social? Sendo que a própria necessidade de transformação social já parte de um posicionamento teórico que entende a sociedade como desigual e opressora de uma maioria da população, assumindo um compromisso em prol de sua transformação.

Consoante a esta compreensão (a partir de raízes epistemológicas, filosóficas e teóricas das mais diversas) a categoria profissional da psicologia ${ }^{4}$ tem debatido sobre o ensino de psicologia no ensino médio propedêutico. Este debate ocorre em duas frentes que caminham conjuntamente. Uma delas é no campo das políticas públicas, por meio da campanha nacional para a inserção da disciplina de psicologia no ensino médio, encabeçada por entidades como Associação Brasileira do Ensino de Psicologia (ABEP), Conselho Federal de Psicologia (CFP), Sindicato dos Psicólogos do Estado de São Paulo (SinPsi), e apoiada por diversas entidades organizativas da categoria dos psicólogos, como o Fórum de Entidades Nacionais da Psicologia Brasileira (FENPB). A outra é no campo efetivo da construção de uma proposta curricular para o ensino de psicologia no nível médio propedêutico, atualmente ocorrendo em debates e grupos de discussão promovidos especialmente pelo CFP em parceria com SinPsi e ABEP ${ }^{5}$.

No âmbito da produção acadêmica, destaco especialmente Leite (2007) e Barros (2007) como autores que trazem reflexões pertinentes sobre o tema. Partindo de um panorama de mundo onde reina a desigualdade, cada autor, a partir de suas matrizes teóricas e posicionamentos pessoais, sugere possíveis contribuições da psicologia no âmbito da educação média propedêutica. Leite (2007), ao analisar o contexto neoliberal da sociedade atual e de sua correspondente ideologia, dirá

4 Ao me referir ao termo categoria profissional da psicologia, busco marcar que a discussão sobre o ensino de psicologia, independente do nível e modalidade educacional em que esteja inserida, tem sido realizada e é tarefa não só de professores de psicologia no ensino médio ou superior, mas dos docentes atuantes no curso de Psicologia, de bacharelandos ou bacharéis em Psicologia, de licenciados e licenciandos em Psicologia, de psicólogos e estudantes de Psicologia, ou seja, todos aqueles que estejam envolvidos no campo da ciência psicológica, em seu desenvolvimento enquanto ciência e profissão.

5 Nos idos dos anos 80, esta discussão foi realizada em parceria com a Coordenadoria de Estudos e Normas Pedagógicas (CENP) do Estado de São Paulo, com participação de psicólogos e teóricos da Psicologia de universidades (Universidade de São Paulo - USP, Universidade Estadual de Campinas - Unicamp, Pontifícia Universidade Católica de São Paulo - PUC-SP), e dela resultou um livro (CONSELHO REGIONAL DE PSICOLOGIA, 1986), rediscutido e atualizado pela CENP (SÃO PAULO, 1992). Ambos trazem uma discussão de possíveis temas e sugestões de bibliografias a serem abordadas pelos docentes da disciplina de Psicologia no ensino médio propedêutico. 
que os mesmos reduzem os homens a sua dimensão apenas econômica, como seres apenas produtores e consumidores, e negligencia dimensões humanas e humanizadoras, como as dimensões estéticas, éticas, lúdicas, políticas, entre outras, sendo papel da educação e da psicologia resgatar tais dimensões e possibilitar aos discentes a compreensão das condições sociais geradoras de conflito nas quais estão inseridos, possibilitando assim a "superação das concepções alienadas e alienantes, relacionadas com a realidade vivenciada e seus impactos na dimensão psicológica dos jovens" (LEITE, 2007, p. 20). Barros (2007) afirma que em um mundo onde reina a barbárie, a psicologia traz elementos importantes "para a compreensão da irracionalidade destrutiva e a aceitação passiva dos homens diante dela, ou do ativismo destes em função de interesses contrários aos seus" (p. 37), sendo assim a psicologia importante para auxiliar os estudantes a compreenderem as disposições subjetivas internalizadas pelo sujeito diante deste contexto e poderem opor resistência a tais modos de subjetivação.

Como apontam os autores, estes seriam princípios que sustentariam a defesa do ensino de psicologia na educação média propedêutica, mas a construção de uma proposta não apenas do ensino de psicologia, mas desta no bojo de uma educação emancipadora e crítica, segundo Leite (2007), não é tarefa para ser realizada isoladamente, mas sim amplamente debatida com a categoria de profissionais da psicologia, de profissionais da educação e da sociedade em geral.

Assim, como visto, há quem discuta o tema do ensino de psicologia na educação média propedêutica, e, ainda que as finalidades da educação técnica sejam outras, penso que tais discussões e proposições nos auxiliam a pensar como o ensino de psicologia poderia contribuir na educação profissional, pois parte-se de como os conhecimentos psicológicos poderiam contribuir para a formação de indivíduos críticos - o que penso tem de estar no horizonte de qualquer atividade educativa. Ainda que haja especificidades no campo da educação profissional, penso que recorrer a essas discussões auxilia porque, especialmente no campo do ensino profissional técnico de nível médio, este é um caminho que ainda precisa começar a ser trilhado.

No entanto, o ensino de psicologia vem perdendo espaço na educação média propedêutica, tendo sido abolido da matriz curricular da mesma no estado de São Paulo, mantendo-se porém um amplo campo de atuação para o licenciado em Psicologia frente às Escolas Técnicas Estaduais de São Paulo (Etecs). Este quadro 
me provoca algumas questões: Por que dentro de uma mesma política estadual a psicologia é abolida do ensino propedêutico e permanece no ensino profissional? A que fins o ensino de psicologia serve no campo das Etecs? Como o ensino de conhecimentos psicológicos se integra aos propósitos da formação profissional? Que conteúdos de psicologia são ensinados nas Etecs? Quais as possíveis contribuições do ensino de psicologia nas Etecs? Por que a categoria profissional da psicologia é omissa quando se trata do ensino de conhecimentos psicológicos no ensino técnico?

Tais questões não podiam ser respondidas de imediato, dada a escassez de discussões, pesquisas e reflexões sobre os conhecimentos psicológicos no campo do ensino técnico, talvez pelo desconhecimento da existência dessa possibilidade de atuação, atrelada ainda a uma histórica desvalorização do lugar da educação profissional na formação do indivíduo, como veremos no primeiro capítulo.

Assim, se a psicologia poderia contribuir em uma educação para a emancipação humana no campo do ensino médio propedêutico, que papel a mesma exerceria no campo do ensino técnico, o qual tem a especificidade de formação de profissionais, características e objetivos próprios? Quais seriam as contribuições do ensino de conhecimentos psicológicos nas Etecs?

Para responder essas questões entendo ser preciso primeiro conhecer e discutir este espaço, buscando as contribuições que o ensino de psicologia traz ao ensino técnico estadual de São Paulo hoje, visto que, a partir do Materialismo Histórico-Dialético, para compreender um tema tão pouco abordado é preciso conhecer sua manifestação fenomênica, a forma como esta se apresenta à primeira vista, para então poder buscar sua concretude ${ }^{6}$.

Para me aproximar do tema e poder assim compreendê-lo a ponto de se fazer possível problematizá-lo e então pesquisá-lo, fiz uma imersão teórica no campo da educação profissional do país a partir de sua história. O primeiro capítulo é fruto da mesma, e neste o ensino técnico é compreendido a partir de sua história em contraste com a história da educação média propedêutica, ambas contextualizadas com a história do país e das formas de organização produtiva. Ainda neste capítulo apresento algumas particularidades ${ }^{7}$ do ensino médio técnico no estado de São

6 Os conceitos de fenômeno (fenomênica) e concreto (concretude) são explicitados no terceiro capítulo.

7 O conceito de particularidade, em sua relação com a singularidade e universalidade é explicitado no terceiro capítulo. 
Paulo, que radicaliza a dualidade entre ensino médio propedêutico e profissional no nível da regulação e supervisão e escancara o domínio da perspectiva econômica utilitarista em seus princípios.

Após esta aproximação teórica com o campo da educação profissional, cabia pensar como a psicologia se insere no mesmo. Não foi possível construir propriamente uma história do ensino de psicologia na educação profissional devido à escassez de material sistematizado sobre o tema, porém busquei uma aproximação a partir das poucas informações encontradas, contextualizadas na história da psicologia na educação e contrastadas com a história do ensino de psicologia no ensino médio propedêutico. Fiz ainda um levantamento bibliográfico que traz quais contribuições sistematizadas têm a Psicologia no campo da educação profissional. Apresento então um panorama do campo do ensino de psicologia na educação profissional a partir de duas recentes dissertações que versam sobre o tema. Por fim exponho as possibilidades de atuação do licenciado em Psicologia junto às escolas técnicas estaduais de São Paulo. Frente a este panorama é que foram construídos os objetivos desta pesquisa, quais sejam:

Objetivo geral: Conhecer e discutir as contribuições do ensino de psicologia no campo das Escolas Técnicas Estaduais de São Paulo.

Objetivos específicos: Conhecer e discutir quais conteúdos são ensinados nas disciplinas com ensino de psicologia e com quais objetivos; conhecer e discutir como os discentes dessas disciplinas interagem com os conteúdos das mesmas e como estas contribuem para sua formação pessoal e profissional; conhecer e discutir a relação dos objetivos e conteúdos ensinados nessas disciplinas com o perfil do profissional que se pretende formar; conhecer e discutir a atuação do professor de psicologia no campo das Escolas Técnicas Estaduais de São Paulo.

No terceiro capítulo explicito o método proposto para alcançar tais objetivos, o qual envolveu os procedimentos de: observação, durante um semestre, das aulas de Psicologia Organizacional (curso de técnico em Administração) e Psicologia Social (curso de técnico em Marketing); conversas informais com participantes da pesquisa e conversa formal com o docente das disciplinas observadas; análise de 
documentos que embasam a prática pedagógica do docente e também que permitiram a caracterização dos discentes da escola campo desta pesquisa. Tal método foi orientado pela perspectiva materialista histórico-dialética ${ }^{8}$, tanto na eleição dos procedimentos, sua efetiva realização, como no processo de análise dos dados. Há ainda neste capítulo a descrição da Etec campo desta pesquisa, o perfil dos discentes e informações sobre o docente das disciplinas observadas.

No quarto capítulo apresento as formas como pude conhecer e discutir o ensino de psicologia nas Etecs. O leitor verá que neste os objetivos da pesquisa foram ressignificados, pois a partir daí pude compreender que o ensino de psicologia nas Etecs estava profundamente condicionado por diversos fatores, e assim não apenas contribuía para algo, mas também expressava seus condicionantes, e desde então passei a falar em expressões e contribuições do ensino de psicologia nas Etecs. A partir da pesquisa compreendi então que o ensino de psicologia nas Etecs expressa e contribui predominantemente para processos potencialmente alienantes e possibilita algumas brechas para processos potencialmente emancipatórios.

No quinto e último capítulo são feitas as considerações finais, no qual resgato o caminho trilhado durante a dissertação, aponto desafios e futuras perguntas de pesquisa a serem exploradas e por fim sintetizo o que pude conhecer e discutir sobre as expressões e contribuições do ensino de psicologia nas Etecs.

Cabe esclarecer que, ainda que a presença da perspectiva materialista histórico-dialética esteja mais evidente a partir do capítulo relativo ao método, tal referencial orientou meu olhar durante toda a pesquisa e do texto dela decorrente. Optei por não apresentar um capítulo teórico sobre esta perspectiva teórica, pois considero que sua vastidão e complexidade seria perdida numa esquematização dessa natureza; e numa exposição apartada do tema de estudo, acabaria formalizando uma separação que não auxiliaria a compreensão do mesmo. Assim, a teoria está presente como referencial que dirige meu olhar e é apresentada ao longo do texto, em estrita relação com os assuntos discutidos. Sua presença é vislumbrada tanto pela aproximação ao tema a partir de sua história contextualizada como pelos autores referenciados, pela explicitação dos conceitos utilizados e

8 Como estuda Anderson (2004), tal referencial é composto por no mínimo duas correntes distintas, porém, nelas não me deterei, e sim naquilo que as unifica sob este mesmo nome, que entendo ser as ideias de Marx, com sua compreensão dos fenômenos a partir da história dos homens e sua vida em sociedade e genericidade, numa relação sempre dialética, que tem clareza da desigualdade social e um compromisso com sua transformação. 
especialmente pelo método desta pesquisa. Mesmo assim, autores não pertencentes a essa tradição de pensamento foram referenciados à medida que suas reflexões e análises, enquanto conhecimentos socialmente construídos, auxiliaram-me na compreensão de alguns aspectos do tema em estudo.

Com exceção dos trechos que explicitamente cito autores ao longo do texto (os quais pude identificar que contribuíram para a minha compreensão dos temas discutidos), optei por apresentar o texto na primeira pessoa do singular, no intuito de assumir a autoria das ideias nele expressas. Vale esclarecer que esta postura revela apenas que este texto é a manifestação singular da compreensão que se fez possível sobre o tema a partir da minha história e do que pude apreender da história dos homens e que reconheço que para a mesma contribuíram tanto os autores citados ao longo do texto como as pessoas que contribuíram para a minha formação (que se encontram citadas nos agradecimentos, além de outras pessoas que por algum lapso me esqueça de creditar). Sendo assim, o texto ora apresentado (como acredito que sejam todos os textos) não deixa de ser uma produção coletiva, singularizada pela ótica da autora que vos escreve, e que pode agora ser discutida, refletida, repensada e, porque não, reescrita, a partir da singularidade do leitor e seus referenciais.

Há ainda em cada capítulo um tópico preliminar que esclarece as escolhas realizadas para a confecção dos mesmos. Julguei que isso auxilia o leitor a compreender as opções que foram feitas para a construção de cada capítulo e os motivos que a elas levaram, balizada por orientações pessoais e teóricas, sendo as mesmas já pertencentes ao método não propriamente da pesquisa de campo, mas do caminho percorrido que orientou sua construção. Como afirmado no capítulo do método, tais escolhas precisam estar explicitadas para possibilitarem assim sua discussão e reflexão.

Realizada a apresentação do tema e feitos os esclarecimentos gerais, convido o leitor a lançar-se à leitura e ao questionamento do texto do tema do ensino de psicologia na educação profissional, começando por uma aproximação ao campo da educação profissional técnica de nível médio. 


\section{EDUCAÇÃO PROFISSIONAL TÉCNICA DE NÍVEL MÉDIO NO BRASIL: UMA COMPREENSÃO POSSÍVEL A PARTIR DA HISTÓRIA}

\subsection{Esclarecimentos preliminares: dos objetivos e concepções que orientaram a confecção do capítulo}

Neste capítulo busquei trazer alguns elementos da história da educação média no Brasil partindo do momento em que esta passa a ser provida, referenciada e supervisionada pelo poder público brasileiro, alcançando um status de política pública e garantindo o início de unidade nacional no âmbito educativo.

Apenas brevemente vou referir-me ao contexto da educação básica como um todo, na medida em que auxilie no objetivo desta exposição, qual seja, compreender o que é o ensino profissional técnico no Brasil e quais as funções que the são atribuídas. Para tanto darei destaque especialmente ao ensino médio em suas modalidades propedêutica e profissional, uma vez que ambas, como aponta Kuenzer (2005), "compõem as duas faces indissociáveis da mesma proposta: a formação de quadros intermediários, que desempenharão, no contexto da divisão social e técnica do trabalho, as funções intelectuais e operativas em cada etapa de desenvolvimento das forças produtivas" (p. 26).

Para os limites da nossa exposição, busquei trazer o ensino profissional técnico como figura ${ }^{9}$ e o ensino médio propedêutico como fundo, ambos imersos num contexto de ideários pedagógicos, políticos e econômicos em embate.

O caminho que optei para pensar tal questão foi primeiramente buscar entender o ensino médio técnico no país a partir de uma versão da história e seus desdobramentos atuais, contada e analisada por educadores de uma orientação crítica, contextualizada em leve medida com a história do país e suas relações exteriores, buscando assim elucidar o campo de forças políticas e ideológicas em luta em cada marco da educação média no país. A escolha dos marcos teve dois parâmetros: 1) valor na configuração do sistema educacional público para o nível médio e 2) possibilidade de elucidação da presença/ausência do ensino de psicologia neste campo, que será analisada no próximo capítulo.

Estes mesmos parâmetros balizaram a escolha das particularidades que a educação profissional técnica assume na rede de Escolas Técnicas Estaduais de

9 Emprestando a metáfora de Ligia Assumpção Amaral (2004). 
São Paulo.

Há alguns trechos do texto compostos pelo destaque de acontecimentos tanto da história do país, como deste em sua relação com o mundo. Tais trechos estão destacados em itálico no texto. Incito o leitor a nos mesmos se deter por algum tempo, remetendo-se assim ao contexto da época onde se dão as iniciativas em relação a educação trazidas na sequência. Entendo que minha formação e o tempo disponível para o mestrado não me permitem nomear articuladamente as relações que suponho se estabeleçam entre tais acontecimentos e os desdobramentos na educação, especialmente a profissional. No entanto, ainda que não possa nomear tais relações - que tampouco penso que sejam diretas, causais -, minhas suspeitas de que tal contexto é relevante me fez optar por destacá-lo no texto, pois julgo serem aspectos que ou são negligenciados ou suprimidos das análises que acessei sobre a educação, e que ao me remeter aos mesmos alguns aspectos da história educacional ganharam sentido.

Busquei trazer no texto uma narrativa das continuidades e descontinuidades na história da educação profissional técnica de nível médio imbricada ao enfrentamento entre as forças políticas e ideários sociais, culturais e educacionais de cada época. Entendo que as análises aqui apresentadas são um destaque pessoal de uma compreensão que se fez possível a partir dos estudos realizados e um recorte do que se considerou mais relevante para o tema da pesquisa. Sendo assim, assumo sua incompletude.

\subsection{Da educação profissional técnica de nível médio: considerações iniciais}

Antes das considerações propriamente históricas da educação profissional técnica no Brasil, considero importante marcar que o que hoje conhecemos como ensino médio tanto propedêutico quanto profissional no país passou por algumas mudanças ao longo de sua história: faixa etária, características socioeconômicas daqueles que o frequentam, funções que lhe são atribuídas, concepções pedagógicas que o orientam, entre outras.

Para além dessas mudanças, o ensino médio no Brasil se constitui enquanto um nível da educação básica fortemente marcado por conflitos e dualidade, que não necessariamente nasceram nele, mas nele se expressam de forma exuberante, 
provavelmente por ser a etapa educativa que primeiro se aproxima das questões trazidas pela maioridade civil e o ingresso no mercado de trabalho.

Busquemos entender as mudanças ocorridas e o que se nomeia por conflitos e dualidades presentes no ensino médio.

\subsection{História da educação profissional técnica de nível médio no Brasil}

O ensino brasileiro começa a se institucionalizar, constituindo o princípio de um sistema nacional de educação, no final do Império e na Primeira República (CASTANHO, 2007). Segundo o autor, diferentemente do que ocorreu com a instrução primária, que teve poucas iniciativas até 1934, neste período houve destaque nas políticas estatais para o ensino secundário e superior, uma vez que a instrução primária seria destinada aos pobres, enquanto os ricos frequentavam ou escolas privadas ou eram instruídos em casa. Já a educação secundária foi alvo de iniciativas públicas na medida necessária para se garantir acesso ao ensino superior, indispensável para a formação de uma elite nacional e para a formação de quadros da administração pública que se organizava no período. Assim, o ensino secundário nasce com a função de preparação para os exames de ingresso ao ensino superior e era destinado aos maiores de 11 anos de idade.

O marco do início de uma educação secundária pública é a criação do Colégio Pedro II, em 1837. Este colégio serviu de modelo ao ensino secundário propedêutico do país, e segundo Cury (1998) teria um ensino gradual e orgânico, com ênfase no ensino clássico de matizes de ensino científico.

Para o autor, tal modelo, hierárquico, de acesso somente às elites, assim se constituiu com influência das heranças do regime escravocrata, em que os privilegiados estão acima das leis e escravos e foreiros não têm acesso aos direitos civis; de uma cultura em que as mulheres não têm acesso ao ensino primário; e da empreitada religiosa contrarreformista característica da Colônia e do Império, que privilegiou o deslocamento da educação primária para o âmbito doméstico ou confessional.

Diante desse quadro, a maioria da população não tinha acesso sequer ao ensino primário, e só candidatos livres e privilegiados, de preferência do sexo masculino, passavam pelos exames de admissão e tinham acesso ao ensino secundário. 
Existia então o modelo do Colégio Pedro II para as elites; e para os pobres, alguma instrução era provida?

Segundo Castanho (2007) paralelamente, a partir da metade do século XIX, houve uma expansão da escolarização primária, tendo como maior motor o chamado, na época, "ensino livre", que nada mais era do que a iniciativa privada, subsidiada em diferentes medidas (dependendo da província) pelo poder público, com característica de assistência aos oprimidos, tendo como principal ator a Igreja Católica. Esta ganhou importância a partir de 1870, com fins de habilitar as classes populares ao direito ao voto. Até esse período nenhuma instrução secundária era provida aos pobres.

O período do final do Império e início da República teve transformações político-sociais marcantes. Promulgação da Lei do Ventre Livre em 1871, a abolição da escravatura, em 1888, o desprezo pela mão de obra recém liberta; concomitante e subsequente, o aumento em massa da imigração de diversas origens para 0 trabalho livre, principalmente a partir de 1880; expansão cafeeira, combinada com criação de ferrovias, bancos, pequenos centros de comércio; tudo isto concorreu para a geração de redes de pequenos núcleos urbanos (FAUSTO, 2001).

Neste contexto ocorreu a primeira iniciativa pública de ensino secundário dirigido aos órfãos e camadas mais pobres da população. São criadas as primeiras escolas de artes e ofícios através do Decreto 7566/1909 (BRASIL, 1909). Segundo Kuenzer (2005), Cury (1998), Schwartzman, Bomeny e Costa (1984) e Castanho (2007), tais escolas tinham uma função moralizante, de educação pelo trabalho, que serviria para evitar a ociosidade dos pobres, e seria um antídoto à vagabundagem e nas quais também se proporcionava a aprendizagem de artes e ofícios. Como enfatiza Kuenzer (2005), "na primeira vez que aparece a formação profissional como política pública, ela o faz na perspectiva moralizadora da formação do caráter pelo trabalho" (p. 27).

Para Castanho (2007), ainda que as escolas de artes e ofícios nasçam nesta perspectiva assistencialista, a educação profissional seria uma modalidade extremamente sensível dentro das sociedades capitalistas, uma vez que estas se constituem mediante a exploração do trabalho. Esta vulnerabilidade da educação profissional em relação às pressões do mercado de trabalho fica evidente nos acontecimentos posteriores.

Fortalecimento da República; intensificação da urbanização; princípios de 
industrialização, reforçada pela necessidade de substituição das importações devido à Primeira Guerra (1914-1918); pressões populares para acesso à educação (FAUSTO, 2001); tudo influi para que o Estado, bem como a classe dominante no país, se volte à educação profissional ${ }^{10}$ : "além de sua finalidade ostensiva, a preparação para o trabalho nas novas condições de urbanização e industrialização, também concorre para a contenção de 'idéias exóticas' que punham em risco a necessária harmonia entre capital e trabalho" (CASTANHO, 2007, p. 53).

Esta preocupação com a expurgação das "ideias exóticas", entenda- se, das ideias comunistas e socialistas, aliada ao ideário de constituição de uma identidade nacional contrária à pluralidade representativa da diversidade de que o país foi constituído, fez, segundo Schwartzman, Bomeny e Costa (1984), a educação assumir um papel de destaque para o Estado e para as classes dominantes da época, atribuindo a ela uma carga ideológica muito forte que buscava atender tais demandas que nela se depositavam.

Em termos de ações, tais demandas se traduziram no início da provisão da educação primária pelo Estado e em uma série de regulamentações que homogeneizassem a população a partir, entre outras coisas, da padronização de currículos e métodos de ensino (SCHWARTZMAN; BOMENY; COSTA, 1984).

Ainda assim, na década de 30 , as iniciativas públicas em relação à educação profissional têm pouca ênfase no que se refere à provisão, mas passa a ser regulamentada pelo poder público por meio de decretos (BRASIL, 1931, 1934) que estabeleciam a vinculação das escolas profissionais a departamentos do Ministério da Educação totalmente desvinculados do departamento responsável pelo ensino propedêutico, formalizando a dualidade que já se expressava na concretude dos sistemas no âmbito de regulação e supervisão. Outra marca importante dessa modalidade educacional é que os estudantes nela formados não poderiam reivindicar o acesso ao nível superior.

Em relação ao ensino secundário, os debates eram muito mais calorosos e as divergências muito mais numerosas. Não cabe aqui me deter nestas questões,

10 Embora pela legislação atual e pelo uso corrente ensino ou educação profissional possam se referir tanto à educação profissional técnica de nível médio quanto à educação profissional tecnológica de graduação e pós-graduação (referindo-se respectivamente ao ensino de nível médio e ensino de nível superior), para proporcionar uma maior fluidez do texto optou-se a partir deste momento em usar a expressão educação profissional, entendendo que já se marcou com precisão que o mesmo refere-se a educação profissional técnica de nível médio. Os termos educação profissional, educação técnica, ensino profissional e ensino técnico serão utilizados como sinônimos no decorrer do texto. 
bastando para esta exposição notar que a educação profissional tem pouco debate, tanto por parte dos representantes do Estado, como dos próprios educadores. A preocupação central fica em torno da educação secundária que será destinada às elites, que nesta época passa a ter dois ciclos, o fundamental de cinco anos e o complementar de dois anos, e que através do Decreto 21.241/1932 (BRASIL, 1932), estende para todo o país o modelo do Colégio Pedro II, no qual, segundo Schwartzman, Bomeny e Costa (1984), permanece a ênfase acadêmico-técnicocientífica, mas passa a destacar especialmente no ciclo fundamental, segundo Cury (1998), a função formativa do ensino secundário, muito relacionada à constituição da unidade nacional.

Assim, a característica da educação destinada aos mais abastados era uma formação acadêmica, intelectualizada, descolada de ações instrumentais, que começa a aproximar a função formativa à propedêutica. E característico da educação destinada aos pobres era primeiramente o assistencialismo e o ensino de formas de fazer que moldassem o desenvolvimento de habilidades psicofísicas, traduzidas em moralização pelo trabalho.

Autores como Castanho (2007), Cury (1998), Frigotto e Ciavatta (2003) e Kuenzer (2005) referem-se à existência desses dois percursos educacionais paralelos - um acadêmico, propedêutico para o ensino superior, e outro voltado à moralização pelo trabalho e posteriormente à formação profissional - como a existência de uma dualidade no sistema educativo brasileiro.

Cabe ressaltar que Baudelot e Establet (1971) são precursores em denunciar a existência dessa dualidade no sistema educacional francês (no qual o sistema educacional brasileiro se baseou), expressa na divisão propedêutica e profissional, mas não restrita à mesma, uma vez que os autores desvendam mecanismos de funcionamento da escola desde o primário que acabam reforçando a divisão de classes sociais. Kuenzer (2005) cunha o termo dualidade estrutural para descrever essa desigualdade de sistemas educativos, expressando por meio deste que tal dualidade é originada na estrutura de classes da sociedade, a qual destina a uma classe as funções intelectuais e de planejamento e à outra as funções técnicas de execução, não sendo ocasional, portanto, a existência de tipos de ensino diferenciado, de acordo com as funções sociais que the seriam atribuídas posteriormente.

Disputas por poder entre segmentos diversos da elite, golpe do Estado Novo, 
promulgação da Constituição de 1937 (SCHWARTZMAN; BOMENY; COSTA, 1984). Nesta Constituição se declara a educação que seria destinada aos pobres, e a justificativa ideológica que a embasaria. Assim, ela prevê em seu artigo 129 que

\begin{abstract}
A infância e à juventude, a que faltarem os recursos necessários à educação em instituições particulares, é dever da Nação, dos Estados e dos Municípios assegurar, pela fundação de instituições públicas de ensino em todos os seus graus, a possibilidade de receber uma educação adequada às suas faculdades, aptidões e tendências vocacionais. (BRASIL, 1937, não paginado)
\end{abstract}

Aqui já aparece a questão de uma certa faculdade, aptidão e tendência vocacional que seria própria aos "desprovidos de recursos". Ainda, no mesmo artigo:

\begin{abstract}
O ensino pré-vocacional profissional destinado às classes menos favorecidas é em matéria de educação o primeiro dever de Estado. CumpreIhe dar execução a esse dever, fundando institutos de ensino profissional e subsidiando os de iniciativa dos Estados, dos Municípios e dos indivíduos ou associações particulares e profissionais. (BRASIL, 1937, não paginado)
\end{abstract}

Como se pode observar, essa aptidão seria a destinação a um ensino prévocacional, de característica de ensino profissional. Observo ainda a questão da imbricação, nessa modalidade de ensino, das iniciativas públicas e privadas, estas últimas subsidiadas pelo poder público.

Schwartzman, Bomeny e Costa (1984) apontam que nesta época se dá a educação profissional uma ênfase nacional desenvolvimentista, e começam os conflitos de bastidores entre o Ministério da Educação e Saúde - que tinha um projeto ambicioso que ao fim levaria à unificação das redes de ensino e previa ainda um Estado ordenador "orientado para fins supostamente mais nobres, e não à mercê dos interesses mais imediatistas dos industriais" (p. 237) - e o Ministério do Trabalho, Indústria e Comércio - influenciado em grande medida pelo setor privado, expresso pela Federação Nacional da Indústria e pela Federação das Indústrias de São Paulo, e que tinha objetivos muito mais pragmáticos: "tratava de implementar um sistema de aprendizagem industrial mais diretamente ligado à indústria e as necessidades práticas” (p. 234), sobre o qual a indústria exerceria controle, apoiando-se nas experiências da Escola Profissional Mecânica e do Serviço de Ensino e Seleção Profissional da Estrada de Ferro Sorocabana, com consultoria de 
Roberto Mange ${ }^{11}$, principal responsável por estas experiências em São Paulo.

A transformação do ensino até então caritativo, identificado pelos liceus de artes e ofícios, para a educação orientada à formação de mão de obra para a indústria em desenvolvimento começa a ser gestada em meio a estes conflitos, que culminam com a promulgação do Decreto 6.029/1940 (BRASIL, 1940), o qual, segundo Schwartzman, Bomeny e Costa (1984), regulamenta os cursos profissionais conforme a ótica do Ministério do Trabalho, Indústria e Comércio.

A rica narrativa do conflito pelos autores permite vislumbrar que ao final houve precedência do mundo do trabalho, dos interesses privados da indústria, em detrimento das características formativas que se esperaria de instituições escolares, justificada por questões orçamentárias de economia de gastos públicos e fundada em subsídios públicos a empresas privadas, com o Estado retirando-se da responsabilidade de estabelecer referências, controle e supervisão público dessa modalidade de ensino. Tal precedência fundou o que hoje conhecemos como educação profissional no país.

Há ainda um agravante, pois ao deixar a cargo das empresas a oferta da educação profissional, estabeleceu-se que esta seria proporcionada a seus empregados, filhos e parentes, ou seja, delimitando na própria oferta a qual segmento da população interessava a educação profissional, perpetuando a dualidade estrutural apontada por Kuenzer (2005).

Segundo Cury (1998) neste período começa a ser regulado e legitimado que a educação profissional ficaria a cargo da iniciativa privada. Cria-se pelo Decreto-Lei 4.048/1942 (BRASIL, 1942a) o Serviço Nacional de Aprendizagem Industrial (SENAI), submetido a Confederação Nacional de Indústria (CNI).

Só posteriormente, como destacam Schwartzman, Bomeny e Costa (1984), é promulgada a Lei Orgânica do Ensino Industrial (BRASIL, 1942b), oriunda de ideias e propostas originárias da área da educação para esta modalidade de ensino, na qual se situa o SENAI como uma das possibilidades de educação profissional. Para os autores a lei é uma ampla declaração de intenções que prevê: uma uniformidade do ensino industrial em todo o país; o oferecimento de formação profissional atrelada à formação humana, dando destaque a última; o atendimento à necessidade de mão

11 Figura que muito influenciou o ensino técnico em São Paulo e no país. Foi professor da Escola Politécnica e do Liceu de Artes e Ofícios além de fundador e diretor do SENAI. Suas ideias se embasavam nos princípios tayloristas e nos fundamentos da psicotécnica (MORAES, 2002a). 
de obra das empresas e de desenvolvimento nacional; a eliminação do estigma do ensino industrial como voltado aos pobres e marginalizados por meio da instalação de um serviço de orientação vocacional; oposição à especialização prematura, buscando articular ensino técnico com disciplinas de cultura geral.

No entanto, tais intenções não foram efetivadas. A lei resultou na criação de uma escola modelo no Rio de Janeiro, sob a ótica de Roberto Mange, que começou a ser implementada em 1940. Houve ali algum investimento e planejamento, porém insuficientes para garantir o sucesso da empreitada.

Na mesma linha da Lei Orgânica do Ensino Industrial foram gestadas neste período outras regulamentações para as modalidades de ensino profissional, as quais foram promulgadas após a queda do Estado Novo. Foram elas: Lei Orgânica do Ensino Comercial (BRASIL, 1943), Ensino Normal (BRASIL, 1946a) e Ensino Agrícola (BRASIL, 1946b). Estas leis acabaram por ter o mesmo destino da Lei Orgânica do Ensino Industrial.

E no campo do ensino secundário propedêutico? Segundo Schwartzman, Bomeny e Costa (1984) esta foi a área que mais recebeu atenção do então ministro da educação e saúde, Gustavo Capanema, e a única que realmente chegou a se efetivar, deixando marcas profundas e duradouras visto que "a legislação casuística, rígida, os currículos de conteúdo classista, uma burocracia ministerial cada vez mais rotinizada e um forte lobby dos diretores de colégio - dariam o tom do ensino secundário brasileiro nas décadas seguintes" (SCHWARTZMAN; BOMENY; COSTA, 1984, p. 202-203).

O ensino secundário deveria ser humanístico, de tipo clássico, em detrimento de uma formação mais técnica. Era destinado à formação da elite intelectual condutora do país (CURY, 1998; KUENZER, 2005; SCHWARTZAN; BOMENY; COSTA, 1984), na qual deveria ser incutida a consciência patriótica em todas as disciplinas e era de acesso apenas aos que passassem pelos exames de admissão. A meu ver, não muito diferente do já estabelecido pelo modelo do Colégio Pedro II a inovação se dá na implantação de um rígido sistema de controle para garantir que o sistema privado em expansão seguisse o mesmo currículo e padrão de qualidade.

Em linhas gerais, a Reforma Capanema ${ }^{12}$, segundo Saviani (2006), previa

12 Há divergência sobre o que os autores entendem ela Reforma Capanema. Aqui estamos entendendo, como Saviani (2006), que a mesma é composta pelo conjunto das Leis Orgânicas promulgadas em seu período como ministro, envolvendo tanto a reforma do ensino secundário propedêutico quanto do ensino profissional. 
um curso primário de quatro anos seguido do ensino médio com duração de sete anos, dividido verticalmente em dois ciclos, o ginasial de quatro anos, e o colegial, de três anos, divididos horizontalmente, por sua vez, nos ramos secundário, normal e técnico sendo este, por seu turno, dividido em industrial, agrícola e comercial. Ocorre que nesta estrutura apenas o secundário dava acesso a qualquer carreira do ensino superior. Os demais ramos só davam acesso às carreiras a eles correspondentes. Por outro lado, se o aluno quisesse passar de um ramo a outro do ensino médio, ele perdia os estudos já feitos, tendo que começar do início no novo ramo. (SAVIANI, 2006, p. 20-21)

Para Kuenzer (2005), mesmo com limitações começa a esboçar-se uma articulação entre as modalidades técnicas e o ensino secundário, onde os procedentes das primeiras poderiam prestar exames de adaptação que dariam direito ao ensino superior, ainda que tais exames se baseassem no domínio de conteúdos gerais, das ciências, letras e humanidades, saberes da classe dominante ministrados nos cursos secundários, destinados à formação dos dirigentes. No meu entendimento o saber ${ }^{13}$ próprio de um campo específico do trabalho não é reconhecido, é tomado como inferior, não se eleva a categoria de saber, é diminuído, atribuindo-se valor apenas ao saber acadêmico. Ou, como analisam Baudelot e Establet (1971), a escola qualifica o trabalho intelectual e desqualifica o trabalho manual, negando a ideologia proletária e incutindo nesta classe a ideologia burguesa ${ }^{14}$.

O que todas essas reformas deixaram de legado para o ensino no país?

Entendo, assim como Cury (1998), que no âmbito do ensino propedêutico reforçou-se o enciclopedismo, aliado a um nacionalismo exacerbado próprio das ditaduras enquanto no âmbito do ensino profissional foi assegurada a condição de nível secundário. Avançou-se progressivamente no sentido de um estabelecimento de equivalência entre ensino propedêutico e profissional, porém persistiu a dualidade de objetivos - e mesmo de prestígio - quando se compara um sistema de ensino ao outro, percebida até pela grande presença, financiamento e regulação do

13 O conceito de saber utilizado é o de Heller (1987), que situa como saber o conhecimento que se tem da realidade utilizado na vida cotidiana, acrescido das contribuições de Mercado (2002), que, ao analisar saberes docentes, afirma que eles são dialógicos, históricos e socialmente construídos.

14 No entanto, é importante lembrar que estamos numa realidade contraditória e que embora em sua grande maioria as escolas possam reproduzir a ideologia burguesa e servir a manutenção da sociedade desigual e capitalista, Saviani (2008) bem nos lembra haver a possibilidade de se articular a escola com o interesse dos dominados, desde que esta reconheça os limites impostos pela configuração atual da sociedade, mas sem assumir-se impotente diante dos mesmos. 
poder público no ensino propedêutico e pelo incentivo à iniciativa privada no ensino profissional, o qual expandiu-se sem controle e supervisão por parte do poder público à mercê dos interesses privados.

Para Schwartzman, Bomeny e Costa (1984), "o que ocorria na área da educação e da cultura naqueles anos fazia parte de um processo muito mais amplo de transformação do país, que não obedecia a um projeto predeterminado nem tinha uma ideologia uniforme" (p. 18). Pelo contrário, era fruto de luta, no âmbito ideológico entre elementos de racionalidade, modernização e eficiência frente à centralização do poder, disputado pela elite tradicional e jovem. Segundo os autores: "Tempos conturbados, tempo real" (p. 19).

No entanto, ainda que não houvesse uma ideologia uniforme por parte da elite brasileira, para Kuenzer (2005) a persistência da marcada separação entre ensino propedêutico e profissional atende a demandas bem definidas "decorrentes da divisão social e técnica do trabalho organizado e gerido pelo paradigma taylorista- fordista como resposta ao crescente desenvolvimento industrial que passava a exigir mão-de-obra qualificada" (p. 28).

Queda do Estado Novo, experiência democrática com as eleições, início dos trabalhos da constituinte; ao mesmo tempo cassação do partido comunista e intervenção em organizações sindicais; promulgação da Constituição de 1946, que tem um viés liberal-democrático (FAUSTO, 2001).

Neste período, especificamente a partir da década de 1950, continua a estabelecer-se uma progressiva equivalência entre o ensino acadêmico e o profissional, com estudantes podendo transitar pelas duas redes, ainda que com algumas restrições em relação ao cumprimento de disciplinas e exames complementares para acesso ao nível superior (BRASIL, 1950, 1953, 1961). Segundo Cury (1998) há um incremento das duas redes, atribuída ao surto de industrialização e urbanização, que pressionaram a equivalência ao menos legal entre ambas.

Para Kuenzer (2005), ainda, o desenvolvimento dos setores secundários e terciários passa a legitimar outros saberes que não só os acadêmicos, o que também estimula a integração das duas redes, mas o conteúdo ministrado nas mesmas permanece diverso, dificultando a equivalência na prática. Aliado a isto, do ponto de vista do "prestígio auferido pelos destinatários das 'redes', e pelas expectativas de cada qual quanto ao respectivo destino social" (CURY, 1998, p. 79), 
as mudanças não foram significativas. Isso porque, segundo Zibas (2005), o ensino técnico teria sido histórico-socialmente desvalorizado, uma vez que o ideal da formação era o modelo educacional francês, que resistia à educação profissional e a relegava às carreiras desvalorizadas. Para Kuenzer (2005) "continuam a existir dois ramos distintos de ensino, para distintas clientelas, voltados para as necessidades bem definidas da divisão do trabalho, de modo a formar trabalhadores instrumentais e intelectuais através de diferentes projetos pedagógicos" (p. 29).

Após "longa tramitação e diversas vicissitudes" (SAVIANI, 2006, p. 11), há a promulgação da primeira Lei de Diretrizes e Bases da Educação Nacional (LDB), em 1961, resultante da conciliação de diversas facções em luta. Em relação à estrutura do ensino, manteve-se a estrutura da Reforma Capanema, flexibilizando-a, nos moldes que apresentei anteriormente.

Período nacional-desenvolvimentista; golpe de 1964, ditadura; aprofundamento da industrialização e ampliação da urbanização; incentivo à exportação; alinhamento no plano internacional à política norte-americana; aumento da violência por parte dos militares; resistência por parte de estudantes, igreja e classe média (FAUSTO, 2001).

Nesse contexto ocorrem, segundo Cury (1998), as alterações no ensino secundário vigente, buscando articulá-lo às novas necessidades do país. A formação profissional ganha destaque, como fundamental para o projeto desenvolvimentista de então.

Durante o regime militar não há nova promulgação de LDB - foram mantidas as diretrizes gerais e feitas alterações dos dispositivos referentes ao ensino superior (BRASIL, 1968) e ensino primário e médio (BRASIL, 1971). Para Saviani (2006, p. 32), isto é coerente, tendo em vista que não era necessário alterar os objetivos conclamados, mais filosóficos, o novo regime requeria a ruptura nos objetivos reais, que se revelam na forma de organização escolar e nos meios preconizados.

Segundo Cury (1998) a mudança trazida pela reforma do ensino primário e médio "deveria confirmar a tendência técnico-autoritária de se conferir à função profissionalizante uma distinção que ela jamais obtivera" (p. 79). A mesma é resultado de uma proposta encaminhada pelo Ministério da Educação e Cultura e sua radicalização pelo Congresso Nacional - e transforma o antigo primário em ensino de $1^{\circ}$ grau, que passa a ter oito anos obrigatórios, e o ensino secundário em 
ensino de $2^{\circ}$ grau, profissional de modo universal e compulsório, com amplo leque de habilitações profissionais. Assim passou-se "de uma tendência ora mais humanística, ora mais cientificista para uma profissionalização impositiva de três ou quatro anos" (CURY, 1998, p. 79).

Segundo Kuenzer (2005) a reforma no ensino médio trazida por esta lei foi determinada pelo crescente desenvolvimento industrial. Teria o objetivo de suprimento de mão de obra e também de conter as demandas de estudantes secundaristas e seu movimento organizado do final da década de 60 , que reivindicava acesso ao ensino superior.

A reforma é criticada por todos os lados, pois ignorou condicionantes do processo produtivo, a estratificação social, o aumento do ensino superior no setor privado, a inexistência de docentes para suprir a demanda por ela criada, bem como de infraestrutura capaz de propiciar experimentação e aplicabilidade exigidas por um ensino desta natureza, além de deixar margem a muitas interpretações. A lei não chega a ser efetivada e o próprio governo reconhece sua ineficácia (CURY, 1998).

Em 1982, a reforma de 1971 é modificada pela Lei 7.044/1982 (BRASIL, 1982), a qual transforma qualificação em preparação para o trabalho e deixa a formação profissional a critério de cada estabelecimento de ensino.

Para Kuenzer (2005) esta reforma de 1982 regressa ao modelo anterior ao de 1971, com a existência de dois sistemas paralelos, destinados a segmentos distintos da população. Até porque, diz a autora, a dualidade "originada na estrutura de classes, não pode ser resolvida no âmbito do projeto político-pedagógico" (p. 30).

No entanto, uma alteração significativa é produzida pela lei de 1971, mantida na lei de 1982: o ensino de $1^{\circ}$ grau, com oito anos, passa a abranger o antigo ensino primário e o primeiro ciclo do secundário, resultando assim numa formalização da maior duração do ensino comum aos estudantes e a postergação da característica dualidade para os últimos três ou quatro anos de escolarização.

Queda da ditadura; redemocratização do país; inflação; Plano Cruzado; expansão das atividades econômicas; aumento das importações; desequilíbrio fiscal. (FAUSTO, 2001). No panorama internacional declínio da perspectiva socialista, fortalecimento da hegemonia norte-americana e influência de organismos internacionais nas políticas públicas, defendendo o esvaziamento das funções do Estado (ZIBAS, 2005).

Em meio a todos esses acontecimentos, tem início o processo de elaboração 
de uma nova constituinte, que resulta na promulgação da Constituição de 1988 (BRASIL, 1988). Ela não só altera as nomenclaturas de $1^{\circ}$ e $2^{\circ}$ grau para Ensino Fundamental e Médio, mas assegura a gratuidade e progressiva universalização do ensino médio.

É a partir da promulgação desta Constituição, segundo Saviani (2006), que começa a ser construída e depois promulgada a nova LDB.

$\mathrm{Na}$ área da educação, é bastante conhecido e estudado este período dos debates e embates anteriores a promulgação da $\operatorname{LDB}^{15}$ de 1996. Para os limites desta exposição basta dizer que ao final houve dois projetos distintos, um proposto pela sociedade brasileira e outro, que veio a ser efetivamente promulgado, de autoria do então senador Darcy Ribeiro. Para Cury (1998) o contraste entre os dois projetos expressava os conflitos sociais e ideológicos sobre a educação que se queria para o país.

Frigotto e Ciavatta (2003) analisam especificamente o período da década de 1990 (tanto anterior como posterior à promulgação da LDB) e apontam que o campo da educação, como o da política geral do país, subordinou-se às políticas internacionais, com influência externa de organismos como o Banco Mundial, Fundo Monetário Internacional (FMI) - que, como bem lembra Cunha (2002), também tem participação de intelectuais brasileiros -, de forma ativa e consentida por parte dos governantes do país. Esse contexto, capitalista, que prega a ideologia de um Estado Mínimo, traduziu-se, para os autores, no âmbito da política educacional brasileira numa progressiva desresponsabilização do Estado perante a estrutura e o financiamento da educação, focando-se em avaliações e responsabilizando a sociedade civil pelas ações das quais se retira.

O campo do ensino médio, tanto propedêutico quanto profissional (que já tiveram posição de destaque na política educacional), é relegado ao segundo plano, uma vez que os parcos investimentos do Estado se voltam ao ensino fundamental. No âmbito pedagógico se estabelece como referência à educação básica as "competências e habilidades" demandadas pela reestruturação produtiva, com fins de capacitação para o mercado de trabalho, tudo isso imposto por mecanismos de controle e avaliação, transformando o ideário empresarial e mercantil em política unidimensional do Estado, passando este a servir dominantemente interesses privados numa clara ditadura da ideologia do mercado (FRIGOTTO; CIAVATTA,

15 Para um estudo detalhado e aprofundado da questão consultar Saviani (2006). 
2003).

Nessa conjuntura, especialmente no que diz respeito à reestruturação produtiva, Cury (1998) aponta ainda a revolução tecnológica, a qual provoca rompimento com o modelo taylorista-fordista que até então embasava não só processos produtivos, mas também paradigmas educacionais. Ela substitui a rígida divisão de tarefas e o controle externo (característicos do modelo anterior) por uma ênfase no trabalho em equipe e no controle internalizado pelo sujeito, demandando mudanças na esfera educacional, que agora deve formar um trabalhador flexível e adaptável a produção. A formação dita geral do ensino médio propedêutico deve atender a uma preparação para o ingresso no mercado de trabalho.

Ainda em relação à reforma do ensino justificada pela reestruturação produtiva, cabe a ressalva de que as transformações no mundo do trabalho não são homogêneas, mas sim assincrônicas (MORAES, 2002b). Os chamados setores modernos, orientados por uma lógica de acumulação flexível e de organização do trabalho numa orientação toyotista, crescem em simbiose com os setores atrasados (FRIGOTTO, 2007), nos quais poderíamos identificar o trabalho escravo ou mesmo o trabalho regido por uma lógica taylorista-fordista. Ambos convivem entre países, setores produtivos ou mesmo dentro de uma mesma empresa (FERRETI; SILVA JÚNIOR, 2000).

Justificar a reforma do ensino pelas transformações produtivas oculta e contradiz a realidade das condições de trabalho, e, aliado ao modelo de competências - que autores como Ferreti e Silva Júnior (2000), Frigotto e Ciavatta (2006a), Moraes (2002b), Oliveira, R. (2002) analisam como exacerbando a valorização de características individuais do discente, futuro trabalhador, em detrimento das características formativas que um curso deveria prover - busca justificar e transferir ao indivíduo a responsabilidade por um possível desemprego, numa sociedade desigual, de desemprego estrutural (CÔRREA, 2006; FRIGOTTO, 2007; MORAES, 2002b; OLIVEIRA, R. 2002), na qual os arranjos flexíveis ora incluem ora excluem pessoas dos mais diversos níveis de escolaridade e qualificações (KUENZER, 2007a).

Essa mesma ideologia estará presente na educação profissional; no entanto, quando a LDB foi promulgada, manteve-se omissa quanto a esse tipo de educação, dando-a tratamento ambíguo, como apontam Cury (1998), Kuenzer (2005) e Saviani (2006). 
Saviani (2006) identifica que o capítulo que se refere à educação profissional (BRASIL, 1996, Título IV, Capítulo III) parece "mais uma carta de intenções do que um documento legal, já que não define instâncias, competências e responsabilidades" (p. 215). O autor hipotetiza que tal ambiguidade e indefinição sejam propositais, para possibilitar uma regulamentação específica, efetivada pelo Decreto 2.208/97 (BRASIL, 1997). No entanto, o processo para sua aprovação não foi sem embates e resistências, porém, estas foram resolvidas de maneira simples, com a possibilidade de um empréstimo de 250 milhões de dólares do Banco Interamericano de Desenvolvimento (BID) condicionado à aprovação do projeto, como descreve Zibas (2005).

Tal decreto torna a formação profissional sequencial ou concomitante à função formativa do ensino médio, proibindo sua formação articulada, o que, para Frigotto e Ciavatta (2006a), significa o retorno à formalização da dualidade entre ensino propedêutico e técnico, uma vez que separa completamente a educação média da técnica.

Quanto ao plano pedagógico,

a Resolução no 04/99 e Parecer CNE/CEB no 16/99, que traçam as Diretrizes Curriculares Nacionais para os cursos técnicos de nível médio, escancaram a perspectiva economicista, mercantilista e fragmentária mediante a pedagogia das competências e a organização do ensino por módulos, sob o ideário da ideologia da empregabilidade. (FRIGOTTO; CIAVATTA, 2006a, p. 119)

No meu entendimento, só se escancara nesta modalidade de ensino as prioridades assumidas em relação à função da educação em geral, pois o ideário das "competências e habilidades" estão expressos nas diretrizes curriculares nacionais para todos os níveis e modalidades de ensino.

Com a eleição de Lula reacenderam-se as esperanças em torno de políticas voltadas à extinção das desigualdades sociais. No que se refere à educação técnica, segundo Frigotto, Ciavatta e Ramos (2005), esperava-se que a discussão em torno do tema pudesse gerar uma transformação profunda, inclusive na LDB e nas diretrizes curriculares para todos os níveis de ensino, não mais em plena conformidade com o ideário capitalista.

Tal expectativa, segundo os autores, não se realizou. Embora ao menos a dualidade formal reestabelecida no governo anterior tenha sido parcialmente 
destituída devido ao Decreto 5.154/2004 (BRASIL, 2004a) - que regulamentou os artigos da LDB sobre educação profissional e estabeleceu que a educação profissional técnica de nível médio possa se dar também de forma integrada - as iniciativas no plano federal para que isso de fato se efetivasse foram feitas por programas pontuais, de forma estritamente dependente da iniciativa privada, reforçando a vinculação entre demandas do setor produtivo e "competências e habilidades" a serem providas pela educação.

Ainda há poucos estudos que analisem o governo Lula e suas iniciativas sobre a educação profissional técnica, especialmente no seu segundo mandato. Ao acompanhar o até hoje efetivado neste período, reafirmo que, no que se refere à mudança da LDB, a não transformação do ideário capitalista na educação apontada por Frigotto, Ciavatta e Ramos (2005) - prevaleceu, como ficou explícito pela Lei 11.741/2008 (BRASIL, 2008a), que altera apenas marginalmente dispositivos da LDB.

No campo do ensino profissional, houve ainda regulamentações pontuais a partir de resoluções. A mais significativa foi a Resolução 3/2008, que, segundo Parecer CNE/CEB ํㅜ 11/2008, não só modifica nomenclaturas como altera a lógica de organização dos cursos técnicos, saindo da oferta do ensino técnico por áreas profissionais - isto é, segundo a lógica de organização do setor produtivo - para uma organização por eixos tecnológicos, que corresponderiam à lógica do conhecimento e inovação tecnológica (BRASIL, 2008b).

Entendo que, ainda que marginalmente, tal resolução altera as Diretrizes Curriculares Nacionais para Educação Profissional Técnica, pois substituiu parte da Resolução CNE/CEB nำ 4/1999 (BRASIL, 1999) pelo Catálogo Nacional de Cursos Técnicos de nível médio, que contém entre outras coisas o perfil profissional e os temas a serem abordados por cada curso, não mais as competências profissionais exigidas para cada profissão.

A implantação desse catálogo traz ainda a diminuição de 2.700 denominações existentes de cursos técnicos para 155, com uma clara preocupação de que a diversidade que existia dificultava a regulação, controle e supervisão dos cursos técnicos da rede pública e privada, conforme aponta o parecer citado. Para além dessa preocupação, examinando o anexo desse catálogo que regulamenta as denominações dos cursos técnicos, percebo que havia ainda a necessidade de conter uma tendência à demasiada especialização já no nível médio. 
Entendo que a substituição da organização dos cursos - de áreas profissionais por áreas do conhecimento e inovação tecnológica - e das características dos cursos - antes pautados por competências profissionais e agora por perfis profissionais e temas - além da contenção de especialização, pode sinalizar um direcionamento das políticas públicas ao encontro de sua não subordinação às demandas do mercado pois, ainda que marginalmente, se distanciam da organização pautada pelo ideário das competências. No entanto, pode significar também o aprofundamento dessa subordinação, pois num cenário que reivindica um trabalhador polivalente, a demasiada especialização ou separação rígida de áreas profissionais não formaria trabalhadores com tais características. $\mathrm{A}$ contradição, característica de uma sociedade dual, permanece presente e permite assim espaço para dúvida, questionamentos e possibilidade para que se efetive uma formação emancipatória nesta modalidade.

Além destas iniciativas, em 2008, pela lei 11.892, instituiu-se a Rede Federal de Educação Tecnológica. Em seu art. 7ํㅡ a lei prevê que os institutos que compõem a rede devem ministrar prioritariamente educação profissional técnica de nível médio em cursos integrados (BRASIL, 2008c). Ou seja, ao menos na educação profissional técnica provida pelo poder público federal se dá preferência aos cursos integrados, ainda que a União não tenha estabelecido o mesmo para a grande diversidade de cursos técnicos públicos e privados existentes no país.

Como aponta Saviani (2007), no plano da concepção houve um avanço, pois as regulamentações enfatizam a articulação entre as modalidades (propedêutico e técnico) e níveis de ensino (fundamental, médio e superior), retomando-se a tendência da formação integrada e a superação da dualidade entre educação geral e formação profissional.

Tais mudanças não são fruto apenas de uma luta política em favor da formação integrada e de uma conjuntura de diálogo do poder público com as demandas da classe trabalhadora. Kuenzer (2007a) aponta que as mudanças no mundo do trabalho, regidas por um discurso da acumulação flexível, repercutem na educação e demandam uma formação geral integrada à trajetória laboral, articulando teoria e prática, trabalho intelectual e operacional, numa aparente superação da dualidade no nível da formação individual que, no entanto, se mantém na separação entre os proprietários dos meios de produção e a força de trabalho.

Para a autora, a educação, ou mesmo o trabalho, que articule as dimensões 
teóricas e práticas, trabalho intelectual e manual, resgataria a unidade como expressão de uma prática individual. No entanto, a dualidade se acentuaria na dimensão social, pois um núcleo de trabalhadores gozaria dessa unidade - para os quais o domínio do conhecimento se converteria em vantagem individual, a ser vendida e adquirida - e manteria grupos de trabalhadores periféricos, temporários, subcontratados, incluídos e excluídos ao sabor das necessidades do mercado (KUENZER, 2007a, p. 1164).

No entanto, ainda que o resgate da unidade entre saberes acadêmicos e práticos no âmbito educativo se dê a partir das demandas do mercado por um trabalhador flexível e que a dualidade estrutural se mantenha, a integração entre formação geral e profissional nas escolas técnicas públicas parece favorecer uma formação com maiores níveis de qualidade quando consideramos mecanismos de avaliação como o Exame Nacional do Ensino Médio (ENEM).

Segundo dados do Ministério da Educação (BRASIL, 2009a) referentes à prova objetiva do ENEM de 2009, das 100 escolas com melhor desempenho no estado de São Paulo, dez são públicas, todas elas escolas técnicas, sendo quatro Institutos Federais de Ciência e Tecnologia, um colégio técnico vinculado à Unicamp, dois colégios técnicos vinculados a UNESP e três Etecs.

Ainda que possam ser feitas críticas à ênfase nos processos avaliativos baseados somente no desempenho dos discentes e aos tipos de conhecimento medidos por essas avaliações, em detrimento de políticas públicas que busquem melhorar a qualidade da educação nacional, não se pode negar que por essa medida há uma diferença significativa de desempenho entre discentes de escolas públicas técnicas e propedêuticas.

Como bem pontua Frigotto (2007), a comparação é simplista, pois além de possuírem uma proposta pedagógica diferenciada, via de regra as escolas técnicas gozam de condições mínimas de funcionamento ausentes nas escolas públicas propedêuticas, como existência de grupos de pesquisa, laboratórios atualizados e espaço físico adequado, sem falar das condições de trabalho e remuneração diferenciadas.

O reconhecimento social dos níveis de qualidade dessas escolas e as transformações pelas quais passaram acabam se revertendo numa reconfiguração do seu público. Como vimos, nos primórdios da educação no Brasil, a destinação para as redes técnica ou propedêutica foi primeiramente baseada na classe social - 
às elites o ensino propedêutico, provido pelo poder público, e aos oprimidos, depois às classes médias, o ensino profissional, provido em larga medida pela iniciativa privada com subsídios públicos. Cunha (2002) aponta que a partir de 1961, no período da ditadura, há uma expansão da rede de ensino pública e do acesso das camadas populares a esta, ao mesmo tempo em que as camadas mais ricas da população começam a se deslocar do ensino médio propedêutico público para a iniciativa privada. Começa aí uma reconfiguração dos destinatários de ambas as redes. Sem muito nos delongar, hoje é muito difícil caracterizar quem são os estudantes do ensino médio público tanto propedêutico quanto profissional.

Segundo Cunha (2002), estudiosos brasileiros vinculados a organismos internacionais, como Oliveira e Castro (apud CUNHA, 2002), identificam como estudantes do ensino profissional público no país a classe média desejosa de uma educação secundária gratuita de qualidade que garanta acesso à universidade. Cunha (2002) em parte reconhece essas afirmações, mas as situa na deterioração dos sistemas públicos de educação propedêutica e na seletividade do acesso às escolas técnicas, feito por um sistema de exames de ingresso pelo qual passam os que tiveram uma educação primária de qualidade (fator que pode também auxilia a explicar a diferença de desempenho no ENEM das escolas técnicas quando comparadas às escolas públicas propedêuticas). Observo ainda que outra questão pode influir no perfil de discentes do ensino técnico: os oprimidos que conseguem chegar ao Ensino Médio - considerando que, segundo os Parâmetros Curriculares Nacionais (BRASIL, 2000, p. 53), menos de 50\% da população entre 15 e 17 anos está neste nível de ensino - por vezes já estão inseridos no mercado de trabalho e não podem dispor de mais horas para a formação que seria exigida ao cursar o ensino profissional não integrado.

Em síntese, no âmbito das regulamentações, o ensino médio propedêutico vai assumindo com destaque a função de preparação para o mercado de trabalho, tendo a lógica deste último como referência, mas mantém a organização curricular clássica e enciclopédica, tendo apenas recentemente o programa experimental do "Ensino Médio Inovador" (BRASIL, 2009b), que busca rompê-la. Já na educação profissional técnica de nível médio, a formação estritamente técnica é revestida com contornos da possibilidade de articulação com a formação geral, a qual ainda que se conforme ao ideário da reestruturação produtiva e o tipo de trabalhador que esta demanda - orientada por um paradigma toyotista, com ênfase na flexibilidade e 
numa subjetividade ajustada a mudanças -, possibilita no nível individual o resgate da unidade dos saberes acadêmicos e práticos, do trabalho intelectual com o manual, numa formação possivelmente emancipatória, que poderia levar à formação de um indivíduo pleno e crítico, mas que também serve à formação de trabalhadores mais flexíveis, que se adequem com rapidez aos arranjos flexíveis do setor produtivo.

Por fim, no atual contexto parece não ser apenas o ensino técnico que possui uma suscetibilidade especial ao mundo produtivo, pois os parâmetros do mercado de trabalho tem penetrado em todos os níveis e modalidades de ensino. Em verdade, para Wood (2003), isso não se restringe à educação, pois a esfera econômica do mundo do trabalho invade todos os espaços da vida, como o lazer e o ócio.

\subsection{Particularidades da educação profissional técnica de nível médio no estado de São Paulo}

Discorri sobre o ensino profissional técnico numa amplitude federal. Procurando não repetir o que já foi analisado, buscarei a seguir trazer alguns contornos que nos aproximem, aprofundem e destaquem as particularidades da modalidade no âmbito estadual.

Um ano após a criação das escolas de artes e ofícios no nível federal, segundo Moraes (2002a), em 1910 são criadas em São Paulo as primeiras escolas oficiais de ensino profissional do estado. Diferentemente dos liceus, que tinham caráter assistencialista, essas escolas faziam parte de um projeto de constituição de um mercado interno de mão de obra qualificada, destinada a filhos de trabalhadores que seguiriam a profissão de seus pais.

Segundo Cunha (2000, p. 115),

A formação profissional, como elemento de impulso da industrialização, desenvolveu-se nesse estado por existirem aí, ao contrário dos demais, certas condições indispensáveis: 1) capital acumulado na cafeicultura de exportação, disposto a transferir-se para a manufatura; 2) capacidade empresarial, isto é, mentalidade burguesa voltada para a acumulação de capital; 3) mercado consumidor para produtos fabris, formado não só pela burguesia, como também, pelas camadas médias e pelos trabalhadores assalariados; 4) um contingente de trabalhadores (notadamente de imigrantes e seus descendentes) dispostos a se transferirem da agricultura para a manufatura e indústria, como operários e até mesmo como empreendedores; 5 ) oferta de energia elétrica para suprir as empresas de 
força motriz.

A partir daí, as iniciativas de São Paulo no campo da educação profissional servem em grande medida de modelo para os rumos na esfera federal da educação técnica no país.

Alguns exemplos disto, segundo Moraes (2002a) são:

a) imbricação do poder público com o privado, preconizada pela parceria de escolas técnicas estaduais com as empresas ferroviárias;

b) a aproximação do ensino técnico às necessidades de mercado de cada localidade;

c) a montagem e organização do serviço e gabinetes de psicotécnica, em 1934, os quais tinham por objetivo selecionar alunos de forma a direcioná-los a profissões mais adequadas às suas aptidões, acompanhar rendimento dos estudantes e realizar a readaptação profissional de operários em trabalho nas indústrias.

A particularidade em São Paulo foi a radicalização da dualidade das redes de ensino médio propedêutico e profissional, formalizada na regulação e supervisão, que, na maior parte de sua existência, foram destinadas a órgãos totalmente distintos. Interessante notar que grande parte das Escolas Técnicas Estaduais de São Paulo oferece também ensino médio propedêutico, mas mesmo este é subordinado à Secretaria de Desenvolvimento ${ }^{16}$ e não à Secretaria de Educação.

Entendo que a diferença de secretarias expressa objetivos distintos entre a rede de escolas técnicas e a de escolas propedêuticas. Enquanto historicamente a Secretaria de Educação é responsável pelas políticas de educação básica paulista, a Secretaria de Desenvolvimento objetiva "intensificar o desenvolvimento sustentável do Estado, estimular as vantagens competitivas das empresas e dos empreendedores paulistas, incorporar tecnologia aos produtos da região e fortalecer as condições para atração de investimentos no Estado" (SÃO PAULO, 2010a). Não há qualquer menção à finalidade educativa desta secretaria, o que me instiga a

16 No início de 2011, esta secretaria foi transformada na Secretaria de Desenvolvimento Econômico, Ciência e Tecnologia, após a subordinação da Secretaria de Ensino Superior à mesma, a qual foi extinta (SÃO PAULO, 2011a, 2011b). Não foi possível no escopo desta dissertação aprofundar a reflexão sobre as consequências da transformação, porém, se por um lado ela poderia significar a articulação do ensino médio profissional ao ensino superior, numa primeira aproximação, parece que a intenção é de deixar universidades e faculdades públicas estaduais ainda mais vulneráveis e subordinadas à lógica da produção de conhecimento e mão de obra a favor do mercado. 
hipótese de que as Etecs estariam vinculadas a ela única e exclusivamente para servir a esses objetivos declarados, como se houvesse uma relação direta entre 0 investimento no ensino técnico e a promoção do desenvolvimento de São Paulo.

Segundo Kuenzer (2007b) o investimento no ensino técnico a partir do viés da tecnologia parte de uma premissa ideológica (e assim apenas parcialmente verdadeira) de que o desenvolvimento atingido nos países desenvolvidos foi possível pelo investimento sistematizado na busca e uso de modernas tecnologias, por meio da formação de recursos humanos capazes de absorvê-las, desenvolvê-las e gerá-las. O que essa premissa oculta são as determinações que mantêm a posição de dependência do Brasil em relação aos países desenvolvidos, fruto do seu papel na divisão internacional de trabalho (OLIVEIRA, R., 2002), atribuindo à educação uma missão messiânica de salvadora da pátria, como se a desigualdade de desenvolvimento não derivasse de processos históricos de dominação e relações de poder assimétricas (FRIGOTTO; CIAVATTA, 2006a).

Investir no desenvolvimento de tecnologia faz parte de um projeto nacional desenvolvimentista desde a era Vargas (SCHWARTZMAN; BOMENY; COSTA, 1984); no entanto, como aponta Oliveira, R. (2002, p. 265), o Brasil

tende a implementar um modelo de desenvolvimento subordinado no que se refere à produção de ciência e tecnologia, o que provoca a não-criação de postos de trabalho em áreas estratégicas para a concepção de produtos competitivos no mercado global.

$\mathrm{E}$, no caso do investimento nas Etecs, parece que o equívoco se mantém, tendo em vista os critérios para a criação de escolas ou cursos, calcados na demanda por mão de obra qualificada na região (SÃO PAULO, 2004) e vocações do setor produtivo (SÃO PAULO, 2011c), que levam em consideração as empresas já existentes na região, porém não assumem um papel indutor em relação ao desenvolvimento de tecnologia e geração de novos postos de trabalho em áreas diversas das já existentes.

Atualmente existem no estado de São Paulo 198 Etecs, distribuídas em 150 municípios, oferecendo uma diversidade de 91 cursos técnicos, dentre eles três na modalidade semipresencial, três integrados ao ensino médio e dois integrados ao ensino médio na modalidade de Educação de Jovens e Adultos ${ }^{17}$ (SÃO PAULO,

17 O oferecimento dos cursos integrados começou em 2010. 
2010b).

Para o governo do estado de São Paulo, as Etecs significam "emprego quase garantido", com índice de empregabilidade de $80 \%$, equivalem ao "primeiro passo de uma carreira profissional de sucesso" e "são reconhecidas por oferecer excelentes cursos e totalmente adaptados a realidade do mercado. Em outras palavras, formam profissionais na área que o mercado precisa", e "os alunos recebem propostas de emprego enquanto ainda estão estudando" (SÃO PAULO, 2009, não paginado).

Reforça-se a ideia de que o curso técnico "dá uma espécie de passaporte para o emprego, ou nos termos da ideologia dominante, permite a empregabilidade" (FRIGOTTO; CIAVATTA, 2006b, p. 359), assumindo uma relação direta e causal, de ordem individual, entre educação e trabalho, formação e emprego, ocultando-se que o desemprego é determinado por fatores de ordem macroeconômica (MORAES, 2002b) e que os arranjos flexíveis característicos do sistema de produção vigente ora incluem, ora excluem trabalhadores das mais diversas qualificações, importando mais a adaptabilidade a esses arranjos do que qualificações formais, supondo "subjetividades disciplinadas que lidem adequadamente com a dinamicidade, com a instabilidade, com a fluidez" (KUENZER, 2007a, p. 1168).

Coloca-se a educação como um bem privado, mercadoria que se adquire e se torna propriedade daquele que teve o privilégio de a consumir (FERRETI; SILVA JÚNIOR, 2000). Apela-se à supremacia das necessidades privadas para a sobrevivência (CARVALHO, 2008), sendo a formação do indivíduo relegada ao segundo plano, numa perspectiva econômica utilitarista que ideologicamente assume a defesa de alegados impactos econômicos na vida dos indivíduos, obscurecendo o sentido político dos princípios da educação subordinarem-se ao mercado de trabalho.

Quanto à orientação pedagógica e curricular das Etecs, não encontrei nos sites do Centro Paula Souza ou de sua Unidade de Ensino Médio e Técnico (CETEC) qualquer documento que as explicitasse (pesquisa realizada em dezembro de 2010). No entanto, um artigo de Almério Melquíades de Araújo (2001), desde a época coordenador do Ensino Técnico do Centro Paula Souza, nos auxilia a desvendar qual seria a orientação pedagógica e curricular nas Etecs.

O autor descreve nesse artigo o processo de reestruturação curricular dos cursos técnicos nas Etecs a partir da impossibilidade de oferta de cursos integrados preconizada pelo Decreto 2.208/97 (BRASIL, 1997), a qual persiste na rede de 
Escolas Técnicas Estaduais ainda que tal decreto tenha sido revogado. Segundo o autor as mudanças implantadas nos cursos técnicos tiveram como característica a estruturação de cursos em módulos e seguiram as Diretrizes e Referenciais Curriculares Nacionais do Ensino Técnico, fundando-se nas competências e habilidades conforme indicado por estes documentos.

A noção de competência, explícita nos documentos, enfatiza a importância do saber ser e do saber tácito, não dependentes do que se aprende formalmente, resgatando a subjetividade do trabalhador ao mesmo tempo em que vai ao encontro das condições de desemprego estrutural e precarização do trabalho, inculcando no trabalhador valores e objetivos tanto da competitividade e da individualidade como da dinâmica da produção e do consumo, próprios do estágio atual de acumulação capitalista (OLIVEIRA, M., 2002).

Tal noção, aliada à oferta de cursos modulares - nos quais o discente não precisaria completar o curso para obter uma certificação, bastando cursar algum dos módulos ou mesmo transitar entre módulos de cursos distintos, obtendo assim uma diversidade de certificações -, representaria uma fragmentação do conhecimento que reduziria o saber e a técnica a questões operacionais (FRIGOTTO; CIAVATTA, 2006a), além de opor-se frontalmente a uma formação integrada, buscando na escola uma polivalência subordinada à polivalência exigida no mercado, reafirmando também neste âmbito a privatização da educação (FRIGOTTO; CIAVATTA, 2006b).

Mesmo assim, a contradição não deixa de estar presente, pois, como aponta Vendrameto (2005), é também a partir dessa reforma que são incluídas nas matrizes curriculares dos cursos técnicos disciplinas como "Ética e Cidadania", "Informática", "Leitura e Produção de Textos", "Tecnologia e Meio-Ambiente" e "Gestão e Qualidade", que buscariam diminuir as perdas acarretadas pela desvinculação entre ensino propedêutico e profissional, resgatando dimensões de uma formação geral.

Após esta compreensão da educação profissional no Brasil e suas particularidades no estado de São Paulo, suas contradições, conflitos e dualidade, podemos nos lançar às especificidades que 0 ensino de psicologia possa assumir frente a este campo, o objetivo do próximo capítulo. 


\section{O ENSINO DE PSICOLOGIA NA EDUCAÇÃO PROFISSIONAL TÉCNICA DE NÍVEL MÉDIO}

\subsection{Esclarecimentos preliminares: dos objetivos e concepções que orientaram a confecção do capítulo}

No capítulo precedente fiz uma contextualização histórica dos caminhos trilhados pela educação profissional no país e suas particularidades no estado de São Paulo. Neste capítulo buscarei trazer um pouco da história do ensino de psicologia nessa modalidade educacional articulando-o com as funções atribuídas ao ensino médio em cada período. Tal tarefa é árdua por três motivos: 1) escassez de material sistematizado sobre ensino de psicologia no ensino técnico; 2) diversidade dos cursos técnicos; 3) longo período sem referências sobre quais conteúdos precisariam ser abordados em cada habilitação profissional.

Embora se considere de grande importância que tivéssemos mais informações sobre a história da psicologia na educação profissional, os motivos elencados apontam para a dificuldade de se construí-la. Se há poucos materiais que versam sobre o assunto (o que ficará evidenciado pela revisão bibliográfica), a grande diversidade de cursos técnicos ${ }^{18}$ torna difícil o exercício de abstração necessário ao se falar do ensino profissional como algo uno, assim como qual psicologia é apropriada, e com que fins, nesse amplo e diverso campo. Tanto mais difícil ponderar sobre uma modalidade educacional em que o poder público historicamente se absteve de prover referências, possibilitando que um mesmo curso em diferentes instituições assumisse características de currículo muito diversas, diferentemente do que ocorreu no ensino médio propedêutico, que desde a Reforma Capanema possui uma unidade nacional.

Ainda frente a tais dificuldades, entendo que um maior aprofundamento na dimensão histórica poderia trazer elementos fundamentais para a análise de qual psicologia e com que fins a mesma é apropriada na educação profissional, porém construí-la seria outra pesquisa, que demandaria conhecimentos de historiografia e

18 Os cursos técnicos atualmente abrangem diversas áreas, distribuídos em 12 eixos tecnológicos - como saúde, educação, lazer - e uma diversidade muito grande de cursos (atualmente 185) como Estética, Reciclagem, Agente Comunitário de Saúde, Orientação Comunitária, Administração, Música, Marketing, entre outros (BRASIL, 2010a). 
implicaria o abandono do trabalho que optei por fazer: compreender como hoje a psicologia é encontrada nas Etecs.

Assim, para minimamente conseguir abordar alguns elementos dessa história em relação às funções que o ensino de psicologia possa exercer na educação profissional, utilizarei o recurso do contraste entre as poucas informações conseguidas sobre ensino de psicologia na educação técnica e a história do ensino de psicologia no ensino propedêutico - esta última abordada apenas em suas linhas mais gerais, e ambas contextualizadas com a psicologia hegemônica no país na época e com as funções que a educação assumia em cada período. Posteriormente discorrerei sobre a revisão bibliográfica realizada e as contribuições que a mesma traz para elucidar o tema de pesquisa. Por fim apresento um panorama atual do que se conhece hoje sobre o ensino de psicologia no ensino técnico e um levantamento sobre o campo de atuação para o licenciado em Psicologia nas Etecs.

Tal narrativa busca prover um panorama do ensino de psicologia na educação profissional e traz muito mais questionamentos e apenas algumas análises críticas que nos auxiliam em uma primeira compreensão de como a psicologia se encontra inserida na educação profissional.

\subsection{Breve contextualização do ensino de psicologia na educação profissional técnica de nível médio}

É diante do contexto de lutas, embates e paradigmas conflitantes que constituem o ensino médio em suas modalidades propedêuticas e profissional que se insere a discussão sobre o ensino de psicologia na educação média, o qual esteve presente desde os primórdios da formação de um sistema nacional de educação no país nos currículos de nível médio. Mesmo antes de regulamentada a formação profissional em psicologia, ocorrida em 1962, as ideias psicológicas já se faziam presentes no ensino brasileiro (LEITE, 2007; MASSIMI, 1993; MRECH, 2001, 2007).

Massimi (1993) aponta a presença dos conhecimentos psicológicos na educação média propedêutica no planejamento e organização do ensino público já em 1823. Estes seriam abordados no âmbito dos estudos filosóficos nas escolas secundárias propedêuticas e deveriam abranger a análise das faculdades e 
operações do entendimento e os princípios da moral (MASSIMI, 1993, p. 265). Lembremos que a psicologia era neste período ainda um ramo da filosofia e não tinha alcançado seu status de ciência, sendo, segundo Antunes (1998), parte da metafísica e tinha como objeto de estudo a alma, o espírito, o eu, trazida pelas mãos de teólogos, professores e médicos. Entendo que os conteúdos psicológicos que se inserem na educação média tinham assim um certo viés moral (pela influência teológica) e ao mesmo tempo normativo (pela via médica), porém não visavam a aplicação de seus conhecimentos e tampouco a adequação dos estudantes, já que se nos recordarmos, a função do ensino médio na época era apenas de preparação para os exames de ingresso ao ensino superior. Massimi (1993) aponta ainda que a presença de tais conhecimentos (assim como de todos os outros que compunham a educação média) eram muito mais reflexo de uma transposição acrítica do modelo educacional francês e o que este considerava importante para a formação de uma elite (como vimos no capítulo anterior, a acumulação de conhecimentos enciclopédicos desvinculados do saber prático) - pouco se relacionavam a realidade agrária e rural do país.

Consta na literatura consultada que o primeiro aparecimento da psicologia como disciplina ocorre no estado de São Paulo, em 1893, nas escolas normais ${ }^{19}$. Pelo detalhamento trazido por Massimi (1993), entrevejo uma psicologia aplicada à moral, com estudos de temas (como instintos, consciência, memória, generalização, liberdade, sentimentos patrióticos, religiosos, de família, de verdade, do belo e do bom), que sugerem a permanência da psicologia com as influências teológicas e filosóficas, contígua ao adentramento da psicologia experimental.

19 A escola normal também oferece uma educação de nível médio e, apesar de conceitualmente poder ser enquadrada no bojo das escolas profissionais (visto que o estudante que a conclua sai habilitado a exercer a profissão de professor para educação infantil e séries iniciais), na esfera legal e mesmo na produção acadêmica se constituiu numa modalidade de ensino à parte, compartilhando características tanto do ensino propedêutico quanto do profissional. Nela não me detive no capítulo antecedente e aqui a abordo apenas de forma marginal por ser uma modalidade educacional na qual, segundo Massimi (1993) e Mrech (2007), o ensino de psicologia teve historicamente seu espaço garantido, mas que por seu caráter híbrido não auxiliaria no objetivo desta exposição: pelo contraste com o ensino propedêutico possibilitar a compreensão do ensino de psicologia no ensino médio profissional. Além disso, a modalidade normal não mais existe no sistema público estadual de educação do estado de São Paulo, o qual será campo de estudo mais direto desta pesquisa. Importante esclarecer o mito de que a formação de professores em nível médio não poderia mais existir e que as determinações legais que sugeriam tal interpretação - LDB 9.394/96 e Decreto 3.276/1999 - foram revistas e passaram a obedecer a Resolução CNE/CEB 01/2003 e o Decreto 3.554/2000, ambos assegurando a validade da formação na modalidade normal para o exercício da profissão docente na educação infantil e anos iniciais do ensino fundamental. 
Esta última, segundo Patto (1984), alcança o status de ciência ao tomar por empréstimo técnicas de laboratório provindas das ciências naturais. Nasce atrelada aos ideais de uma ciência positivista e não escapa às determinações de sua época, de uma ideologia determinista e antidialética, repetindo e naturalizando, talvez sem o saber, os chavões da ideologia burguesa ocidental. Para os limites desta exposição basta dizer que é esta psicologia, junto à psicanálise trazida com um enfoque médico, que se perpetua no Brasil e em suas aplicações na educação, servindo à previsão, controle e ajustamento dos estudantes, à naturalização da desigualdade social e à normatização de comportamentos que, desviantes, deveriam ser tratados numa prática clínica individual com fins de promoção da "cura".

Tal psicologia adentra cada vez mais a educação nas escolas normais, não apenas por meio do ensino do instrumental que serviria ao professor para controle e domesticação de seus discentes, mas pela instalação de laboratórios de pedagogia experimental e gabinetes de psicologia científica, que deveriam prover os instrumentos de medição necessários à aplicação dos conhecimentos da psicologia. Entram em cena os testes psicológicos de inteligência, aptidão e personalidade, profundamente comprometidos com os ideais de selecionar, orientar, adaptar e racionalizar, naturalizando as desigualdades sociais por meio da justificação científica das aptidões individuais (PATTO, 1984).

São os conhecimentos dessa psicologia experimental, revestidos de seu caráter científico, que são inseridos na disciplina de Psicologia, obrigatória para o sexto ano do ensino secundário propedêutico ${ }^{20}$ a partir de 1893. Nesse período a psicologia já está apartada da filosofia - excluída então do currículo por ser considerada metafísica e em não conformidade aos ideais de ciência hegemônica da época (MASSIMI, 1993) - e de posse de técnicas de previsão e controle. Mas ainda aqui penso que o que marca a inclusão da disciplina é a transposição do modelo educacional francês, inspirado por seus ideais iluministas e servindo, naquele contexto industrial capitalista, à justificação e à naturalização das desigualdades. No

20 Pelos estudos realizados para a confecção do capítulo anterior, acrescido das informações contidas em Moacyr (1942), pode-se admitir que o sexto ano corresponderia atualmente ao segundo ano - se levarmos em consideração uma progressão de anos - ou terceiro ano do ensino médio propedêutico -se levarmos em consideração que o ensino de segundo grau da época era composto por seis anos. Ainda que se compreenda a inadequação de precisar uma equivalência linear entre os sistemas de ensino da época com a atual organização do ensino, admitiu-se realizá-la aqui apenas para prover uma referência de em que momento da escolarização era previsto o ensino de psicologia. 
contexto brasileiro, ainda que possa servir à justificação das desigualdades de uma sociedade de transição do agrário para o industrial, o conteúdo da psicologia me parece ser muito mais enciclopédico do que destinado a fins formativos e presente apenas porque seus conhecimentos eram requeridos nos exames de ingresso para o nível superior.

E quanto ao ensino de psicologia na educação profissional? Até o momento sequer me referi ao assunto, porque, até esse período a educação profissional sequer existia. Ela começa a existir provida pelo poder público em 1909 e a adquirir as características de formação profissional anos mais tarde.

Mesmo assim, Soligo e Azzi (2009) apontam que não demora à psicologia passar a integrar os cursos profissionais ligados a saúde, direito, e relações humanas. Quanto à psicologia que era aqui ensinada, pouco se sabe dos seus conteúdos e fins. Num confrontar dos objetivos que pautaram a educação profissional no país, orientada durante muito tempo pelos paradigmas tayloristas e fordistas de produção, com a psicologia que predominou no Brasil até a década de 80 - experimental ou psicanalítica pelo viés médico e higienista (PATTO, 1984) -, entendo que possa ter predominado e se acentuado o uso instrumental de uma psicologia prescritiva do que fazer e como agir - servindo à avaliação e domesticação dos indivíduos - e ideológico - aqui com o objetivo de estabelecimento de padrões acerca do comportamento normal e da internalização pela classe oprimida das justificativas naturalizadas da desigualdade social.

Por trás dessas deduções há o pressuposto de que o tipo de modalidade educacional impõe algumas referências e talvez restrições ao uso que se fará dos conhecimentos no interior de cada uma destas modalidades, prevalecendo na propedêutica o uso burocratizado e na técnica o uso instrumental. Mas não são apenas esses fatores que intervêm, pois como visto os conhecimentos produzidos pela ciência psicológica podem favorecer o tipo de uso que se fará dos mesmos.

Outra influência da psicologia na educação profissional foi por meio dos serviços e gabinetes de psicotécnica, instalados em 1934 em São Paulo, e depois preconizados para todo o país por meio da Lei Orgânica do Ensino Industrial. Aqui a psicologia utilizava seus instrumentos, principalmente testes de inteligência e personalidade aplicados ao estudante, para "apreciação de sua inteligência, aptidões e personalidade, com o fim de auxiliá-lo na adaptação escolar, de modo a facilitar- 
Ihe a escolha do curso mais adequado à sua capacidade" (BRASIL, 1942b, art. 33, não paginado). O texto da lei deixa claro que a psicologia aqui servia à adaptação do estudante a uma possível profissão configurada, como expus no capítulo precedente, pelos padrões do mercado de trabalho. A instalação de tais serviços é justificada por Capanema (SCHWARTZMAN; BOMENY; COSTA, 1984) como um rompimento da destinação de classe que até então vigorava na determinação de quem frequentaria o ensino propedêutico ou profissional por meio de seleção embasada num saber racional, científico, em testes psicológicos e de inteligência que certificariam a adequabilidade do indivíduo, que aparece, no entanto, desgarrado das questões sociais. Assim a existência de tais gabinetes e o uso que se fazia da psicologia nos mesmos ao invés de se contrapor terminava por servir à justificação da estrutura social existente e naturalizava as desigualdades sociais. Ou seja, um exemplo da psicologia aplicada servindo a uma mudança que acaba por reforçar a ideologia dominante (CHAUÍ, 1981).

E após esse período, o que ocorre com o ensino e ações da psicologia na educação profissional? Pouco se sabe. Voltarei ao ensino propedêutico para ver se, pelo contraste do que ocorre nessa modalidade, posso hipotetizar o que ocorre no ensino técnico.

Assim como ocorre com a educação no país, que passa por diversas reformas, a presença/ausência da psicologia no currículo da educação média propedêutica também está atrelada às transformações sociais, políticas e ideológicas pelas quais o país e o mundo passavam (como discutido no capítulo anterior desta dissertação). O Jornal do Conselho Regional de Psicologia de São Paulo (CONSELHO REGIONAL DE PSICOLOGIA, 2008) traça em seus aspectos gerais uma linha do tempo em relação às idas e vindas da psicologia como disciplina que ora figura como obrigatória, ora optativa, ora com seus conhecimentos inseridos em outras disciplinas, ora totalmente extirpada do currículo.

O período mais significativo para os objetivos de nossa exposição em relação a tais variações da psicologia no ensino médio propedêutico é o de sua extirpação do currículo, a qual ocorre durante o período da ditadura militar (BARROS, 2007; LEITE, 2007; MRECH, 2001) que, lembremos, em 1971 estabelece a profissionalização compulsória, e ainda que esta não tenha sido efetivada nestes termos, as disciplinas das áreas de humanas acabam sendo excluídas dos currículos 
do ensino propedêutico ${ }^{21}$, ainda que mantidas nos cursos técnicos, como por exemplo o curso de contabilidade, no qual existia a disciplina de Psicologia das Relações Humanas.

No entanto, se a psicologia estava presente nos cursos técnicos, por que quando a educação técnica é preconizada a psicologia é expulsa do ensino agora profissionalizante ${ }^{22}$ ? A resposta pode estar naquilo que se pretendia estabelecer no período: não o incentivo a formações profissionais da área da saúde, relações humanas e formação de professores - áreas nas quais a psicologia se fazia presente -, mas sim a formação de quadros de trabalho para a indústria, que requeria um trabalhador treinado para exercer as ações técnicas de sua profissão. Quando esse tipo de ensino não se estabelece, o governo ditatorial impõe o recrudescimento do controle ideológico e expurga da educação qualquer conhecimento que tenha algum potencial questionador. Mesmo que a psicologia estivesse muito comprometida com a adaptação dos sujeitos à sociedade - e, neste momento, segundo Mrech (2001, p. 148), seus conhecimentos tenham se tornado ainda mais conformistas -, no contexto educacional vinha no bojo das ciências humanas, podendo talvez no diálogo com outras áreas acabar questionando suas bases e produzir fissuras num sistema já na época questionado por intelectuais, pelo movimento estudantil secundarista e pelos próprios educadores.

Findada a ditadura, em 1982 o ensino mais geral é restabelecido. Diante de um contexto pós militar, havia um clima popular desejoso, articulado e combativo por uma educação mais humana. Aos poucos a psicologia, assim como a filosofia e a sociologia, retorna aos currículos, ao menos no estado de São Paulo ${ }^{23}$, a fim de favorecer a construção do pensamento crítico dos estudantes de ensino médio propedêutico (BARROS, 2007; LEITE, 2007; MRECH, 2001).

Lembremos que no período a psicologia também repensava suas bases,

21 Isto ocorre pelo menos com as disciplinas de psicologia, filosofia e sociologia, que figuravam como optativas no período anterior.

22 Conforme distinção de Cunha (2002), que nos esclarece que ensino profissional diz respeito à formação de profissionais - no caso técnicos de nível médio - enquanto ensino profissionalizante diz respeito à educação geral que pode vir a ser útil para futuros profissionais, como acaba por se configurar o ensino na época.

23 Como psicologia, filosofia e sociologia figuram como optativas da parte diversificada do currículo, em cada sistema de ensino sua existência e seu retorno podem ter assumido características diferenciadas. Faltam informações para que seja possível falar de um panorama nacional. 
descortinando o viés ideológico que envolvia suas teorias e práticas. Uma conjunção de fatores para isso concorrem, dentre eles o contexto do país na época que, num período de endurecimento do controle estatal, deixa expostas as contradições sociais, questionadas e refletidas pela academia e pela sociedade, tornando possível perceber e desvelar as vinculações ideológicas dos fundamentos teóricos hegemônicos até então. Um dos marcos desse desvelar na psicologia são as reflexões de Patto (1984), que irá buscar na filosofia, sociologia, história e educação os fundamentos necessários para realizar uma análise crítica da psicologia voltada à educação, questionando a serviço de quem e do que a mesma se coloca. Souza (2007) nos lembra ainda que a pesquisa de Maluf (1994 ${ }^{24}$ apud SOUZA, 2007) aponta que a transformação das práticas profissionais comprometidas com a ideologia dominante tem origem na inserção profissional do psicólogo junto às classes populares, produzindo questionamento e movimentação de seus fundamentos teóricos.

Esse efervescer é ainda trazido para repensar a psicologia no então segundo grau, sendo construída em São Paulo uma proposta curricular do ensino de psicologia para o ensino médio propedêutico, fruto de discussões e reflexões no CRP-SP, SinPsi, APEOESP e CENP, junto a candidatos a docência de Psicologia, com participação de acadêmicos reconhecidos na época como não conservadores (da USP, Unicamp e PUC-SP), todos interessados na sistematização de conhecimentos que proporcionassem uma formação humana e crítica aos estudantes dessa modalidade educacional. Leite (2007) discute o período, apontando que, após a conquista da realização de concurso público para cargos de professores de psicologia, a discussão ao redor do tema perde força, um dos fatores, segundo o autor, da psicologia não poder mais compor a parte diversificada do currículo do ensino médio propedêutico na rede pública estadual em São Paulo.

A diminuição gradativa da oferta de cursos de licenciatura em Psicologia (KOHATSU, 2010; SOLIGO, 2011) e o tratamento marginal dado à habilitação em licenciatura nas próprias Diretrizes Curriculares Nacionais para os cursos de Psicologia são fatores que dificultam o retorno do ensino de Psicologia no âmbito do ensino médio propedêutico e arriscam sua abordagem crítica no ensino técnico. Isso

24 MALUF, M.R. Formação e atuação do psicólogo na educação: dinâmica de transformação. In: ACHAR, R. Psicólogo brasileiro: práticas emergentes e desafios para a formação. São Paulo: Casa do Psicólogo, 1994, p.195-250. 
porque, se há poucos cursos formando professores de psicologia, gradativamente existirão menos docentes habilitados a ministrarem tal disciplina, e também menos profissionais envolvidos com a licenciatura, o que pode fazer com que a discussão em torno do tema se torne cada vez mais escassa. Com relação às Diretrizes Curriculares Nacionais para os cursos de psicologia, ao relegarem a licenciatura ao espaço de "um projeto pedagógico complementar e diferenciado" (BRASIL, 2004b, p. 5), demonstram um não comprometimento com "um plano pedagógico que abarque a formação de professores" (CIRINO et al., 2007, p. 29). Soligo (2011) acrescenta que ao situar a licenciatura em um lugar periférico na formação, perdeu-se conjuntamente um espaço de formação política, cultural e histórica das questões educacionais, as quais seriam importantes não só para o professor de psicologia, mas também para o psicólogo escolar e para a superação do viés clínico da Psicologia no campo da educação ${ }^{25}$.

Entendo que tais fatores demonstram o quanto a categoria profissional da psicologia é omissa em relação ao ensino de psicologia no nível médio e a formação de professores para o mesmo. A situação agrava-se quando nos voltamos ao ensino técnico, pois, como se pode entrever pelo texto até agora apresentado, pouco há de conhecimento sistematizado sobre o tema. Soligo e Azzi (2009) são as únicas autoras encontradas por mim que abordam o assunto, e a informação que trazem é de que, na ditadura, enquanto a psicologia era suprimida do ensino propedêutico, foi

25 No processo de finalização desta dissertação, foram promulgadas novas Diretrizes Curriculares Nacionais para os cursos de graduação em Psicologia (BRASIL, 2011), que acrescentam à legislação anterior oito parágrafos referentes à formação de professores de Psicologia. Mantém-se a formação de professores em projeto pedagógico complementar e diferenciado, mas ao contrário das diretrizes anteriores que se abstinham de estabelecer como deveria se dar tal formação, nas atuais diretrizes se estabelecem objetivos, eixos estruturantes, conteúdos e carga horária para o curso. Entendo que há muito a ser discutido e refletido sobre a nova legislação e suas consequências para os cursos de licenciatura e formação de psicólogos, inclusive sobre as especificidades de um curso de licenciatura e a própria adequação destas diretrizes à legislação que regulamenta as licenciaturas em geral (regulamentação contida em BRASIL, 2002a, 2002b), no que diz respeito à carga horária e um possível retorno ao tão discutido e criticado modelo $3+1$ (sobre este modelo ver nota 27 , p. 51). Porém, entendo como um ganho que os cursos superiores de graduação em Psicologia sejam expostos à discussão da licenciatura e que a categoria profissional como um todo seja convidada, por meio destas diretrizes, a sair de seu lugar de omissão quanto ao assunto. Para o espaço desta dissertação cabe apenas ressalvar que a nova legislação, no meu entender, recupera o espaço que Soligo (2011) analisava como perdido, ao prever que "os conteúdos que caracterizam a Formação de professores de Psicologia deverão ser adquiridos no decorrer do curso de Psicologia" (BRASIL, 2011, p. 6). Contrapõe-se ainda à gradativa diminuição dos cursos de licenciatura em Psicologia ao prever que as atividades referentes à formação de professores "serão oferecidas a todos os alunos dos cursos de graduação em Psicologia, que poderão optar ou não por sua realização" (BRASIL, 2011, p. $6)$. 
mantida na formação de professores e nos cursos profissionais nas áreas de saúde e relações humanas. Para as autoras isso ocorre devido à sua "essencialidade para a atuação daqueles que trabalham diretamente com o humano, em suas várias dimensões" (p. 58). Ainda que concorde com as autoras, entendo que, diante do contexto político social que se tinha, a psicologia só permanece aqui provavelmente por se tratar de uma psicologia em sua aplicação instrumental, menos ameaçadora do ponto de vista de possibilitar reflexões críticas, como deixam entrever as análises de Patto (1984) da psicologia no campo da formação de professores, uma psicologia técnica adaptacionista ou clínica individualista que servia à justificação do sistema social.

$E$, assim como o silêncio de educadores e poder público marcou o ensino profissional até a década de 40, num indicativo de descaso com a modalidade educacional, o mesmo predomina até os dias de hoje no que diz respeito ao ensino de psicologia na modalidade técnica. Se os profissionais de psicologia historicamente negligenciaram a pesquisa e discussão sobre a licenciatura e o ensino de psicologia no ensino médio propedêutico, considerando-a como área de menor importância conforme aponta Mrech (2001), o quadro se reforça em grandes proporções quando o ensino de psicologia na educação profissional está em questão. Se, como apontam Soligo e Azzi (2009), o ensino de psicologia sempre esteve na educação profissional, como é possível tal silêncio por parte da categoria em relação a ele? Será que há realmente um silêncio?

Busquei responder tais dúvidas por meio de revisão bibliográfica sistematizada que apresento sinteticamente ao leitor no próximo tópico.

\subsection{Busca por contribuições a partir de revisão bibliográfica}

Ao realizar a revisão bibliográfica, optei num primeiro momento por pesquisar as contribuições que a psicologia produziu sobre ensino técnico, e não especificamente sobre ensino de psicologia nesta modalidade educacional. Interessava saber o que o campo de conhecimento da psicologia tinha a dizer sobre a educação profissional técnica de nível médio e se haviam contribuições que versassem sobre 0 ensino de psicologia. A escolha das palavras-chaves foi orientada por esse princípio. Como a educação profissional técnica de nível médio 
passou por diversas mudanças de denominação em sua história, foram usadas combinações de termos-chave para apreendê-las. Não realizei uma restrição em relação ao período de abrangência da busca bibliográfica, pois o material era escasso, a ponto de se fazer possível analisá-lo e assim construir uma dimensão de como o tema foi abordado ao longo do tempo, seja no encontrado ou em suas ausências.

A revisão bibliográfica foi realizada entre os dias $1^{\circ}$ e 8 de junho de 2010, e foram utilizados para a mesma os acessos eletrônicos: Portal de Periódicos Capes, através da ferramenta busca integrada, que abrangeu as bases Psyclnfo, Scielo, Web of Science e SCOPUS; Biblioteca Virtual em Saúde - Psicologia, com as bases Indexpsi, Lilacs, PePSIC e Scielo; e a Biblioteca Digital de Teses e Dissertações Nacional.

Apresento a seguir tabelas que organizam os resultados da busca, separados por base de dados, com a indicação dos termos-chave utilizados, o número total de resultados e o número de resultados de acordo com classificação realizada a partir dos resumos dos textos encontrados como: muito relacionadas ao tema (quando versavam sobre ensino de psicologia na educação profissional); relacionadas ao tema (quando versavam sobre conhecimentos produzidos pela psicologia sobre educação profissional ou sobre a licenciatura em Psicologia e sua relação com ensino técnico); e não relacionadas ao tema (quando versavam sobre outros assuntos). A cada tabela discorro brevemente sobre as pesquisas encontradas muito relacionadas e relacionadas ao tema, buscando estabelecer relações com as mesmas que me auxiliem a compreender o ensino de psicologia na educação profissional. Ao final do capítulo olho para o conjunto das pesquisas encontradas e em linhas gerais traço o que a revisão bibliográfica pode nos revelar sobre as relações da psicologia com o ensino técnico.

Feitos tais esclarecimentos, vejamos agora o resultado da revisão bibliográfica $^{26}$, começando pela busca realizada por meio da ferramenta de pesquisa integrada do acesso eletrônico Portal de Periódicos Capes, apresentada na Tabela 1.

26 Para possibilitar ao leitor o acesso a revisão bibliográfica realizada, e que este avalie por si a classificação feita em relação as pesquisas, o Apêndice $A$ traz quadros nos quais constam autor, título, referência, bem como a classificação realizada de todos os artigos obtidos por meio das ferramentas de busca utilizadas. 
A pesquisa encontrada por meio desta busca que se relaciona ao tema da presente dissertação foi de Morais et al. (1985). Tal pesquisa analisa a implementação de atividades de orientação profissional em escolas com ensino técnico-profissional de Portugal. A descrição das atividades e dos pressupostos que as orientaram permite entrever que tal orientação profissional compreendia o indivíduo localizado em sua relação com o mundo e sua escolha profissional como processual. Suas atividades ultrapassaram as funções de avaliação e diagnóstico e envolveram ainda a equipe escolar. Identifiquei tais práticas numa perspectiva mais emancipatória, e é interessante notar que embora o serviço de orientação vocacional tenha existido também nas escolas técnicas do país, a única pesquisa encontrada que versa sobre o mesmo é do sistema português de ensino, que me parece muito distinto do que foi implementado na educação profissional no Brasil por volta dos anos 40 .

Tabela 1 - Resultado da revisão bibliográfica realizada por meio da ferramenta pesquisa integrada do Portal de Periódicos Capes, nas bases Psyclnfo, Scielo, Web of Science e SCOPUS.

\begin{tabular}{|c|c|c|c|c|}
\hline Termos utilizados & $\begin{array}{c}\text { Pesquisas muito } \\
\text { relacionadas } \\
\text { ao tema }\end{array}$ & $\begin{array}{l}\text { Pesquisas } \\
\text { relacionadas } \\
\text { ao tema }\end{array}$ & $\begin{array}{l}\text { Pesquisas não } \\
\text { relacionadas } \\
\text { ao tema }\end{array}$ & $\begin{array}{l}\text { Total de } \\
\text { pesquisas }\end{array}$ \\
\hline $\begin{array}{l}\text { "escola tecnica" and } \\
\text { Psicologia }\end{array}$ & 0 & 0 & 3 & 3 \\
\hline $\begin{array}{l}\text { "escola profissional" and } \\
\text { Psicologia }\end{array}$ & 0 & 0 & 1 & 1 \\
\hline $\begin{array}{l}\text { "ensino tecnico" and } \\
\text { Psicologia }\end{array}$ & 0 & 1 & 0 & 1 \\
\hline $\begin{array}{l}\text { "ensino profissional" and } \\
\text { Psicologia }\end{array}$ & 0 & 0 & 0 & 0 \\
\hline $\begin{array}{l}\text { "educação tecnica" and } \\
\text { Psicologia }\end{array}$ & 0 & 0 & 0 & 0 \\
\hline $\begin{array}{l}\text { "educação profissional" } \\
\text { and psicologia }\end{array}$ & 0 & 0 & 0 & 0 \\
\hline
\end{tabular}

Na Tabela 2 apresento o resultado da busca realizada por meio do acesso eletrônico Biblioteca Virtual em Saúde - Psicologia (BVS-PSI). Nessa busca as pesquisas encontradas que se relacionam ao tema da presente dissertação foram: Stutz e Jansen (2006), Simões e Paiva (2007) e a biografia de Oswald Barros Santos 
(BVS-PSI, 2010).

A pesquisa que Stutz e Jansen (2006) desenvolveram analisa, a partir de um olhar cognitivo-comportamental da psicologia escolar e educacional, dificuldades encontradas por discentes do curso técnico de enfermagem quando iniciam o estágio curricular. Em seus achados apontam que as maiores dificuldades encontradas pelos estudantes se referiam a relacionamento interpessoal e comunicação, sugerindo que as mesmas poderiam ser minimizadas por uma organização da situação de estágio que favorecesse a comunicação entre discentes, equipe de saúde e docentes. Ainda que não aborde a questão do ensino de psicologia, entendo que a pesquisa das autoras pode nos sugerir temas que poderiam ser trabalhados no ensino de psicologia, como a comunicação e formação de vínculos no ambiente de trabalho, e relações entre trabalho e stress.

Tabela 2 - Resultado da revisão bibliográfica realizada por meio da BVS-PSI.

\begin{tabular}{lcccc}
\hline Termos utilizados & $\begin{array}{c}\text { Pesquisas muito } \\
\text { relacionadas ao } \\
\text { tema }\end{array}$ & $\begin{array}{c}\text { Pesquisas } \\
\text { relacionadas } \\
\text { ao tema }\end{array}$ & $\begin{array}{c}\text { Pesquisas não } \\
\text { relacionadas } \\
\text { ao tema }\end{array}$ & $\begin{array}{c}\text { Total de } \\
\text { pesquisas }\end{array}$ \\
\hline $\begin{array}{l}\text { (ensino tecnico) } \\
\text { psicologia }\end{array}$ & 0 & 2 & 23 & 25 \\
\hline $\begin{array}{l}\text { (escola tecnica) } \\
\text { psicologia }\end{array}$ & 0 & 1 & 37 & 38 \\
\hline $\begin{array}{l}\text { (educação profissional\$) } \\
\text { Psicologia }\end{array}$ & 0 & 0 & 17 & 17 \\
\hline $\begin{array}{l}\text { (educação tecnica) } \\
\text { psicologia }\end{array}$ & 0 & 0 & 0 & 0 \\
\hline $\begin{array}{l}\text { (escola profissional\$) } \\
\text { psicologia }\end{array}$ & 0 & 0 & 0 & 0 \\
\hline $\begin{array}{l}\text { (ensino profissional\$) } \\
\text { Psicologia }\end{array}$ & 0 & 0 & 0 & 0 \\
\hline
\end{tabular}

Já o artigo de Simões e Paiva (2007) descreve o processo de reformulação da licenciatura em Psicologia na Universidade do Estado do Rio de Janeiro (UERJ). Faz um resgate histórico da licenciatura em Psicologia, como área recente $\mathrm{e}$ historicamente desvalorizada, fundada e organizada de forma que os conhecimentos da educação e pedagógicos ficavam restritos ao final ou complementar ao curso de 
graduação $^{27}$. Ao repensar o curso de licenciatura em Psicologia da UERJ, pelos temas eleitos pelas autoras como pertinentes ao ensino, entendo que se visou à formação do professor para o ensino propedêutico, porém os estágios dos discentes da UERJ são desenvolvidos nas escolas técnicas estaduais do Rio de Janeiro. Tal artigo traz contribuições interessantes para pensar a formação dos professores de psicologia, mas perpetua o silêncio sobre o campo do ensino profissional, suas especificidades, seus limites e possibilidades, bem como quais contribuições e responsabilidades têm a formação em licenciatura para a prática dos futuros professores que venham a atuar nas escolas técnicas.

Outro conhecimento encontrado foi no Dicionário Biográfico da Psicologia no país, sobre a figura de Oswald de Barros Santos (1918-1998), que trabalhou no gabinete de psicotécnica da Escola Técnica Getúlio Vargas e no SENAI, realizando principalmente pesquisas e aplicação de testes de inteligência e aptidões. Também envolveu-se principalmente na clínica de orientação rogeriana, no aconselhamento psicológico. O pesquisador tem diversas produções sobre orientação profissional, a relação desta com o trabalho e o desenvolvimento de testes. No entanto, sua produção mais específica sobre o trabalho de orientação profissional nas escolas técnicas é uma apresentação em um Congresso de Psicologia de 1938, ao qual não tive acesso, não permitindo assim uma análise de qual psicologia estava inserida neste contexto. Apenas pelas práticas descritas, infiro que se mantinha um uso da psicologia comprometido com a ideologia dominante, conforme analisado anteriormente. Mesmo que o autor tenha trabalhado durante tanto tempo no ensino técnico, é interessante notar que tenha uma única contribuição sistematizada pensando a relação da orientação profissional com a escola técnica. Mais uma vez o silêncio sugere que o campo da educação profissional, embora tenha sido um campo de atuação possível aos psicólogos da época, seja desvalorizado, sendo a produção desse autor expressão de uma possível desvalorização ocorrida entre os profissionais da psicologia.

Por fim na Tabela 3 segue o resultado da busca realizada por meio do acesso eletrônico Biblioteca Digital de Teses e Dissertações Nacional. Nesta busca foram

27 Importante salientar que esta forma de organização não é específica dos cursos de licenciatura em psicologia, mas é o conhecido modelo $3+1$, característico das licenciaturas em geral no país, em que, em linhas gerais, os três primeiros anos de formação ficam reservados aos conhecimentos específicos e um último ano de complementação pedagógica aos que querem se formar como licenciados. 
encontradas três pesquisas relacionadas ao tema (LEMOS, 2008; ROCHA, 2005; ZULKE, 2007) e duas pesquisas muito relacionadas ao tema (MACIEL, 2009; PIRES, 2009).

Tabela 3 - Resultado da revisão bibliográfica realizada por meio da Biblioteca Digital de Teses e Dissertações Nacional.

\begin{tabular}{lcccc}
\hline \multicolumn{1}{c}{ Termos utilizados } & $\begin{array}{c}\text { Pesquisas muito } \\
\text { relacionadas ao } \\
\text { tema }\end{array}$ & $\begin{array}{c}\text { Pesquisas } \\
\text { relacionadas } \\
\text { ao tema }\end{array}$ & $\begin{array}{c}\text { Pesquisas não } \\
\text { relacionadas ao } \\
\text { tema }\end{array}$ & $\begin{array}{c}\text { Total de } \\
\text { pesquisas }\end{array}$ \\
$\begin{array}{l}\text { "escola profissional\$" } \\
\text { and psicologia }\end{array}$ & 0 & 0 & 2 & 2 \\
\hline $\begin{array}{l}\text { "educação profissional\$" } \\
\text { and psicologia }\end{array}$ & 1 & 2 & 2 & 5 \\
\hline $\begin{array}{l}\text { "ensino tecnico" and } \\
\text { psicologia }\end{array}$ & 1 & 0 & 1 & 2 \\
\hline $\begin{array}{l}\text { "ensino profissional\$" } \\
\text { and psicologia }\end{array}$ & 0 & 1 & 2 & 3 \\
\hline $\begin{array}{l}\text { "escola tecnica" and } \\
\text { psicologia }\end{array}$ & 0 & 0 & 3 & 0 \\
\hline $\begin{array}{l}\text { "educação tecnica" } \\
\text { and psicologia }\end{array}$ & 0 & 0 & 0 & 3 \\
\hline
\end{tabular}

A pesquisa de Rocha (2005) estuda a constituição da identidade de instrutores do SENAI (que haviam sido estudantes desse mesmo sistema de ensino) e aponta que se este sistema de ensino tem, pela disciplina rígida e seus objetivos, uma estreita vinculação com o mercado de trabalho, ao mesmo tempo possibilita a escolarização e a superação das condições de origem pobre, além dos estreitos vínculos afetivos produzidos entre estudantes e instrutores gerarem um contexto propício ao desenvolvimento de identidades autônomas. Assim como afirma Adorno (1972), que é falsa a presunção de que nada existe imune à pseudocultura socializada - e deixa entrever que mesmo em um contexto de pseudoformação há brechas que podem possibilitar a formação, ainda que muito restrita -, e sendo a pseudoformação produto e produtora da ideologia dominante, entendo que mesmo numa educação com objetivos adaptacionistas não há total controle sobre o que se deseja produzir. Ao mesmo tempo em que produz adaptação, deixa pequenas brechas possibilitadoras de emancipação. Hipotetizo que a mesma contradição de limites e possibilidades formativas se dê no campo das escolas técnicas públicas e 
com o ensino de psicologia nas mesmas.

Em certa medida, a pesquisa de Zulke (2007) corrobora essa hipótese, pois ao analisar os efeitos produzidos pela reforma do Estado - ocorrida a partir da década de 90 - na subjetividade de profissionais da educação profissional, conclui que a reforma se constituiu por um conjunto de saberes e procedimentos úteis às conformações dos sujeitos e à sua adequação às necessidades do capital, o que se manifesta tanto na subjetividade de professores e de outros profissionais quanto dos estudantes formados por estas instituições. Ao mesmo tempo a autora afirma que, mesmo diante desse contexto, podem-se vislumbrar as resistências, percebidas por meio das críticas feitas pelos sujeitos ao sistema que estão submetidos. Conformação e resistência, adequação e possibilidades de emancipação estão presentes neste campo, é o que concluo pela pesquisa.

A pesquisa de Lemos (2008) faz uma análise da legislação brasileira sobre a profissão do psicólogo e a formação do licenciado em Psicologia, identificando, entre outras coisas, que a legislação que regulamenta a profissão na área da psicologia está ultrapassada no que diz respeito às possibilidades de atuação do licenciado em Psicologia e que as atuais diretrizes curriculares para os cursos de Psicologia são uma expressão do descaso dessa área profissional em relação ao exercício da docência na educação média, visto que a licenciatura é colocada num projeto complementar e não articulado à formação de psicólogo, o que contradiz inclusive as atuais legislações para a formação de professores. Traz assim um elemento importante que não pode ser esquecido na análise das práticas dos professores de psicologia, qual seja, as determinações exercidas sobre sua prática decorrentes de seu próprio processo de formação.

As próximas duas pesquisas foram entendidas como muito relacionadas ao tema por mapearem e discutirem o ensino de psicologia na educação profissional. Aqui brevemente discorrerei sobre seus objetivos, mas trarei um detalhamento maior no próximo tópico deste capítulo, cujo objetivo é problematizar o panorama atual do ensino de psicologia no ensino técnico.

A pesquisa de Maciel (2009) mapeia o campo de atuação para o licenciado em Psicologia na cidade de Belo Horizonte, apontando os cursos técnicos como uma possibilidade e descrevendo os conteúdos que aparecem nos Planos de Curso das disciplinas relacionadas à psicologia. 
Já a dissertação de Pires (2009) tem como tema as contribuições do ensino de psicologia para a formação dos técnicos em enfermagem, analisando o quanto a prática dos professores de psicologia e os conteúdos abordados contribuem para a apropriação do "conceito ampliado de saúde" e para o desenvolvimento da "integralidade do cuidado" preconizados pelo Sistema Único de Saúde (SUS).

Pelo panorama da revisão bibliográfica, o que fica evidente ao primeiro olhar é a carência de pesquisas produzidas pela psicologia no campo da educação profissional, o que parece se repetir no campo da sociologia e filosofia da educação, da pedagogia, entre outros, embora esta revisão não o permita afirmar. Confirmo a suspeita de que seja uma área sobre a qual a psicologia se omite e talvez até despreze. Possivelmente seja também uma expressão do contexto social que valora de forma diferenciada as modalidades de ensino propedêutico e profissional, prestigia a formação e trabalho intelectual em detrimento do trabalho manual e do saber da prática, conota de forma negativa o ensino técnico, sem sequer conhecê-lo, e abstêm-se de discutir tal campo.

Observo ainda que tal quadro começa a mudar a partir dos anos 2000, onde majoritariamente se localizam as pesquisas encontradas. Passa-se a pensar a formação na área da psicologia, as possíveis contribuições da psicologia escolar e do ensino de psicologia para a educação profissional de técnicos em enfermagem e os efeitos na educação profissional sobre a subjetividade de estudantes, professores e demais profissionais envolvidos. Despontam ainda discussões nos órgãos e associações organizativos da categoria, como podemos comprovar pela cartilha do Conselho Federal de Psicologia $(2010)^{28}$ à Conferência Nacional de Educação $(\mathrm{CONAE})^{29}$, que apresenta em uma de suas propostas "discutir o ensino de psicologia na educação profissional" (p. 22).

Mas talvez mesmo tais alterações sejam um indicativo de que a psicologia se volta à educação profissional e dispõe-se a conhecê-la apenas quando ela não tem

28 Esta cartilha é produto de debates realizados - no ano de 2008, por meio do Sistema Conselhos de Psicologia -, com psicólogos que trabalham na área de Educação. A construção de seu texto é fruto da articulação do Conselho Federal de Psicologia, da Associação Brasileira de Psicologia Escolar e Educacional e da Associação Brasileira do Ensino de Psicologia.

29 Realizada entre 28 de março a $1^{\circ}$ de abril de 2010 em Brasília, numa parceria dos sistemas de ensino, órgãos educacionais, Congresso Nacional e sociedade civil, com fins de estabelecer diretrizes, metas e ações para a política nacional de educação em termos de organização nacional da educação e formulação do Plano Nacional de Educação 20112020. (BRASIL, 2010b). 
mais espaço no ensino propedêutico, quando possivelmente as instituições de ensino superior que mantiveram a licenciatura em Psicologia precisam buscar novos campos de estágio para seus estudantes. A pretensão presente nas duas dissertações que abordam o tema - e desta dissertação - é trazer o tema do ensino de psicologia na educação profissional para discussão, conhecê-lo, para só então compreender quais suas possíveis contribuições nesse espaço.

Para realizar tal análise vou me deter com um pouco mais de atenção nas pesquisas que versam sobre o ensino de psicologia na educação profissional.

\subsection{Panorama atual}

Como visto, duas dissertações defendidas em 2009, uma em Minas Gerais e outra no Rio Grande do Sul, discutem como o ensino de psicologia tem atualmente se inserido na educação profissional.

A primeira é de Mariana Sobreira Maciel (2009), que realiza um estudo exploratório sobre o campo de atuação para o licenciado em Psicologia na cidade de Belo Horizonte. Sua pesquisa constatou que em 50\% das instituições de ensino profissional (sejam elas privadas ou públicas, e no último caso se vinculadas ao poder público municipal, estadual ou federal) de Belo Horizonte havia professores de psicologia atuando, distribuídos numa diversidade de 29 formações profissionais, com maior incidência nos cursos de enfermagem e segurança do trabalho, concluindo que o ensino de psicologia esteja vinculado à formação de profissionais que lidam com a promoção da saúde do ser humano.

A partir da análise documental de planos de ensino de disciplinas relacionadas à psicologia nos cursos técnicos, a autora analisa os conteúdos presentes, comparando-os em grupos por formação profissional. Destaco aqui que pela análise da autora em cada profissão a psicologia traz contribuições específicas que convergem (como no caso dos cursos de enfermagem e de segurança do trabalho, que apresentam conteúdos muito similares) e divergem (no caso do curso de magistério) quando se compara diferentes instituições. A autora elenca então quais seriam tais conteúdos.

Prossegue apontando os limites trazidos pela escolha do método da análise documental dos planos de ensino, pois ainda que tenha nomeado os conteúdos 
neles explicitados, para poder compreendê-los precisaria saber se quem ministra tais disciplinas são profissionais da área da psicologia, e especificamente se são licenciados em Psicologia, quem são os responsáveis pela elaboração dos planos de ensino e quais as mediações utilizadas pelo professor em sala de aula para ministrar tais conteúdos.

Como a proposta da autora é mapear os conteúdos da psicologia inseridos nos planos de ensino, não os vincula aos objetivos da disciplina e do curso, e assim pouco nos possibilita supor que psicologia é ensinada, com que fins o ensino de psicologia se insere nos mesmos e quais contribuições estes trazem à formação de seus estudantes.

A outra dissertação que versa sobre o ensino de psicologia na educação profissional é de Fernanda Hampe Pires (2009), que parte de sua experiência em docência em cursos técnicos de enfermagem perguntando-se sobre as possibilidades do ensino de psicologia contribuir para a "integralidade do cuidado" e para a apropriação de um "conceito ampliado de saúde" (questões preconizadas pelo SUS). Suas inquietações são sobre quais conhecimentos da psicologia tem sido disponibilizados à formação de técnicos em enfermagem, a serviço de quê e produzindo o quê.

Para estudar a questão irá levantar quem oferece o ensino técnico de enfermagem, apontando que em Porto Alegre há 15 escolas, todas pertencentes à iniciativa privada. Em oito das escolas há psicólogos ministrando aulas, duas não prestaram informações e em cinco não há professores de psicologia, sendo todas as disciplinas ministradas por enfermeiros. Ao discutir esse último dado, a autora aponta a força do Conselho de Enfermagem, que autoriza os enfermeiros a ministrarem todas as disciplinas nos cursos técnicos de enfermagem.

Sua pesquisa de campo consistiu em entrevistas com docentes psicólogos dos cursos técnicos em enfermagem e com docentes de ensino superior que atuam na formação do licenciado em Psicologia.

Quanto à entrevista com os docentes do ensino superior, aponta a escassez de espaços para se discutir o ensino de psicologia na educação profissional. Ainda que os estudantes realizem muitos dos estágios no ensino técnico, a modalidade é pouco problematizada, segundo a autora numa eleição clara do ensino médio propedêutico como lugar da docência em psicologia, deixando vulnerável já na 
formação do futuro professor a qualidade do ensino a ser desenvolvido na educação profissional. Entendo que tal priorização do ensino médio propedêutico e desvalorização do ensino médio profissional, acarretando problemas na formação do docente que vier a atuar na modalidade técnica, deve ocorrer em grande parte do país, tendo como base o próprio número de pesquisas encontradas sobre a interface psicologia-educação profissional como apresentado na revisão bibliográfica.

Sobre a entrevista com as docentes de psicologia do ensino técnico de enfermagem, apurou que das oito entrevistadas apenas duas tinham a formação em licenciatura ${ }^{30}$ e uma tinha o magistério, sendo que a maioria tinha como atividade principal a clínica em psicologia, supondo que este era o fator decisivo para que as professoras não buscassem uma formação específica para a docência, considerada por tais entrevistadas como complementação de renda, não uma profissão com características específicas que necessitaria de formação própria.

A autora ainda lista e analisa os saberes presentes e ausentes no ensino de psicologia na formação do técnico de enfermagem. Quanto aos saberes presentes, diz que os mesmos estão vinculados em sua maioria a concepções normativas sobre o humano e de legitimação da hierarquia entre os profissionais da saúde. Em alguns momentos, um meio termo entre conhecimentos burocratizados da psicologia, conhecimentos da psicologia aplicados a controle e prescrição de condutas e um espaço terapêutico. Quanto aos saberes ausentes, destaca o conhecimento sobre grupos, que fortalecessem a escuta de coletivos e o trabalho em equipe, em que a subjetividade fosse entendida como processo atravessado pelas questões políticas e sociais e o trabalho considerado produtor de subjetividades.

A autora conclui que o ensino de psicologia na educação profissional não contribui para o "conceito ampliado de saúde" e para a "integralidade do cuidado", apontando que: a formação em psicologia e a área profissional ainda privilegia uma atuação clínica e desconsidera a docência em sua relação com a saúde; falta a necessária formação em licenciatura para garantir diálogo entre psicologia e educação e atentar a que compromissos os conteúdos ensinados estão atados; a

30 Ainda que a LDB 9.394/96 (BRASIL, 1996) preveja que a formação de docentes para atuar na Educação Básica a partir do ciclo II do fundamental deva ser a licenciatura em nível superior ou professores formados em programas especiais de formação pedagógica de docentes, em caráter excepcional é possível admitir graduados em nível superior ou tecnólogos. Na educação profissional ocorre ainda que no nível federal não há regulamentação para que a licenciatura seja na área de conhecimento da disciplina a ser ministrada. 
atuação como professor visa a uma complementação de renda, produzindo um não efetivo compromisso com a docência; o processo de trabalho no âmbito da saúde ainda vigora sob o modelo taylorista-fordista (ainda que os referenciais curriculares da área da saúde e o próprio SUS preconizem o contrário). Porém, mesmo diante desse quadro, a autora - por sua experiência na docência em cursos técnicos de enfermagem e por algumas rupturas no discurso de uma das educadoras entrevistadas - aponta diversos conhecimentos com os quais a psicologia poderia contribuir para a formação dos futuros técnicos em enfermagem, acreditando na potencialidade do espaço.

Até agora apresentei um panorama da educação profissional técnica em Belo Horizonte e discussões sobre o ensino para o técnico em enfermagem em Porto Alegre. E como é composto o quadro do ensino de psicologia na educação profissional técnica de nível médio no estado de São Paulo?

\subsubsection{Etecs, cursos e disciplinas nos quais o licenciado em Psicologia pode ministrar aulas}

Apresento aqui levantamentos realizados com intuito de evidenciar a existência do campo de atuação possível aos licenciados em Psicologia na educação profissional técnica de nível médio pública estadual de São Paulo. A escolha se deu pelo privilegiar do ensino público e porque, como veremos, o ensino de psicologia está muito presente na educação pública profissional estadual, porém "proibido"31 no ensino médio propedêutico da rede pública estadual paulista. Ou seja, um mesmo governo posiciona-se de forma diferenciada quanto ao ensino de psicologia quando se trata de modalidades diferentes, porém que dizem respeito ao mesmo nível de educação.

A seguir apresento como realizei os levantamentos do campo de atuação possível ao licenciado em Psicologia nas Etecs, bem como os resultados obtidos.

Cabe primeiramente esclarecer que a organização das Etecs é regulada pelo Centro Paula Souza, o qual define a matriz curricular de todos os cursos, prevendo as disciplinas que compõem o curso, qual será sua carga horária e em qual módulo do curso serão ministradas. Cada curso tem a mesma matriz curricular independente

31 Para compreender a questão vide a Resolução SE 92/2007 (SÃO PAULO, 2007), que regulamenta a organização curricular nas escolas estaduais propedêuticas. 
da Etec na qual é ministrado. As Etecs não têm autonomia para modificar esta estrutura. Também é definido pelo Centro Paula Souza quais os chamados "requisitos de titulação" permitem que um profissional ministre uma determinada disciplina de um curso, ou seja, estabelece qual a formação acadêmica necessária para ser professor de quais disciplinas.

Embasada nessas informações, realizei um levantamento em 2009 que buscava compreender em quais disciplinas de quais cursos das Etecs o licenciado em Psicologia poderia ministrar aulas. Esse levantamento foi realizado em duas etapas.

Uma das etapas foi realizada no site www.cpscetec.com.br, cruzando os dados obtidos pelo link Catálogo de requisitos técnicos (no qual se obtinha todas as disciplinas existentes e que já existiram no currículo dos cursos oferecidos pelo Centro Paula Souza e que podiam ser ministradas por licenciados em Psicologia ${ }^{32}$ ), com os dados existentes no link Laboratório de currículo (que apresenta o currículo vigente para cada curso já existente no Centro Paula Souza), excluindo-se então as disciplinas que deixaram de existir nos currículos vigentes. O período da busca foi de 18 a 27 de março de 2009, atualizado com dados referentes ao segundo semestre no período de 5 a 23 de junho de 2009.

A outra etapa foi realizada no site www.centropaulasouza.sp.gov.br, no link Manual do vestibulinho referente ao primeiro semestre de 2009 - para ver quais cursos foram oferecidos naquele semestre (consulta realizada em 3 de março de 2009) - e também no site www.vestibulinhoetec.com.br, no link Onde estudar - com os cursos oferecidos no segundo semestre pelo Centro Paula Souza (período da consulta: 8 a 12 de julho de 2009).

Por meio do cruzamento dos dados obtidos em cada uma das etapas é que compreendi quais disciplinas e em quais cursos o licenciado em Psicologia teria um campo para atuar, constatando a possibilidade de ministrar aulas em ao menos 63

$32 \mathrm{Na}$ rede pública estadual de ensino profissional, diferente do que vimos nas pesquisas de Maciel (2009) e Pires (2009), existe uma regulação sobre quais formações profissionais permitem ao docente ministrar determinadas disciplinas em determinados cursos. A maioria das disciplinas possui uma gama de formações profissionais que permitem ministrá-la. Por exemplo, a disciplina de Psicologia Organizacional, constante do currículo do curso técnico de Administração, pode ser ministrada por licenciados nas áreas de Administração, Ciências Administrativas e Psicologia, sendo que há prioridade aos licenciados plenos ou aos que cursaram programas especiais de formação docente. 
de 78 cursos de escolas técnicas públicas estaduais ${ }^{33}$.

Observei que todas as disciplinas nas quais o licenciado em Psicologia pode ministrar aulas são oferecidas em um dos módulos do correspondente curso e tem duração de duas horas por semana dentro de uma carga horária de 20 horas semanais. Cabe esclarecer que isso não significa que todas as demais disciplinas de um determinado curso tenham a mesma duração, visto que tal composição varia de acordo com a especificidade do curso. Por exemplo, o curso de Administração composto por 25 disciplinas, 20 delas com duração de 2 horas semanais e 5 com duração de 4 horas semanais ${ }^{34}$.

A seguir apresento o Quadro 1 com cursos e disciplinas nos quais o licenciado em Psicologia pode ministrar aulas.

A primeira estranheza gerada ao observar este quadro é ausência do licenciado em Psicologia no curso de técnico em enfermagem, pois como apresentei pelas pesquisas destacadas na revisão bibliográfica, a psicologia deteria conhecimentos importantes para a formação desse profissional, além de estarem presentes na habilitação ao menos em Belo Horizonte e em Porto Alegre. O dado se torna compreensível ao analisar que predominantemente enfermeiros podem ministrar aulas nestes cursos nas Escolas Técnicas Estaduais, reforçando o que Pires (2009) havia levantado em relação à força do Conselho de Enfermagem, que autoriza e legitima que enfermeiros ministrem todos os componentes dessa formação profissional. Nas Etecs, isso se agrava pela formalização da impossibilidade de outras formações em nível superior contribuírem para a educação do técnico em Enfermagem (conforme www.cpscetec.com.br/crt).

Analisando mais o quadro, destaco como disciplinas que podem ser ministradas por licenciados em Psicologia: Ética e Cidadania Organizacional, visto estar presente na maioria dos cursos, e as disciplinas Psicologia Organizacional (curso de técnico em Administração), Psicologia Comportamental e Psicologia Social (curso de técnico em Marketing), por explicitarem os conteúdos psicológicos em seu

33 Este era o número de cursos oferecidos pelas Etecs no período de março a julho de 2009. Após esse período a rede de escolas técnicas estaduais continuou em expansão, bem como a diversidade de seus cursos, incluindo-se, excluindo-se ou suspendendo-se cursos em cada período.

34 A título de ilustração, disponibilizo as matrizes curriculares dos cursos de técnico em Administração e Marketing em anexo (Anexos A e B). 
Quadro 1 - Cursos e disciplinas das Etecs nos quais o licenciado em Psicologia pode ministrar aulas.

\begin{tabular}{|c|c|}
\hline Curso técnico & $\begin{array}{l}\text { Disciplinas que o licenciado em Psicologia pode } \\
\text { ministrar }\end{array}$ \\
\hline Administração & $\begin{array}{l}\text { Psicologia Organizacional* } \\
\text { Ética e Cidadania Organizacional** } \\
\text { Gestão de Competências I } \\
\text { Gestão de Competências II }\end{array}$ \\
\hline Marketing & $\begin{array}{l}\text { Psicologia Comportamental }{ }^{\star} \\
\text { Psicologia Social* }^{*} \\
\text { Ética e Cidadania Organizacional** }\end{array}$ \\
\hline Calçados & $\begin{array}{l}\text { Ética e Cidadania Organizacional** } \\
\text { Gestão de Competências I } \\
\text { Gestão de Competências II }\end{array}$ \\
\hline $\begin{array}{l}\text { Agenciamento de viagem } \\
\text { Agente comunitário de saúde }\end{array}$ & $\begin{array}{l}\text { Ética e Cidadania Organizacional** } \\
\text { Relações Humanas }\end{array}$ \\
\hline $\begin{array}{l}\text { Comércio } \\
\text { Design de móveis } \\
\text { Gestão de produção de enxovais de decoração } \\
\text { Secretariado }\end{array}$ & $\begin{array}{l}\text { Ética e Cidadania Organizacional** } \\
\text { Gestão de Pessoas }\end{array}$ \\
\hline $\begin{array}{l}\text { Farmácia } \\
\text { Saúde bucal }\end{array}$ & $\begin{array}{l}\text { Ética e Cidadania Organizacional** } \\
\text { Organização do Processo de Trabalho em Saúde }\end{array}$ \\
\hline Paisagismo & $\begin{array}{l}\text { Ética e Cidadania Organizacional** } \\
\text { Auto-gestão }\end{array}$ \\
\hline Segurança do trabalho & $\begin{array}{l}\text { Ética e Cidadania Organizacional** } \\
\text { Relações Humanas no Trabalho }\end{array}$ \\
\hline $\begin{array}{l}49 \text { cursos das mais diversas áreas. Ex: } \\
\text { Eletrônica; Açúcar e álcool; Agricultura; } \\
\text { Dança; Nutrição e dietética; Prótese } \\
\text { dentária; entre outros }\end{array}$ & Ética e Cidadania Organizacional \\
\hline
\end{tabular}

Eletromecânica

Relações no Trabalho e Desenvolvimento de Pessoas

Agroecologia

Agropecuária modalidade alternância

Não possuem nenhuma disciplina que possa ser ministrada pelo licenciado em Psicologia

Bioquímica

Comunicação visual

Design de interiores

Enfermagem

Mecânica

Redes de computadores

Transporte ferroviário

Telecomunicações

Canto

Caracterização cênica

Composição e arranjo

Reabilitação de dependentes químicos

Regência

* disciplinas que explicitam o ensino de conteúdos psicológicos em seu nome

** disciplina que se repete na maioria dos cursos

No período da pesquisa, não tinham as matrizes curriculares disponíveis 
nome. Esclareço ainda que a disciplina de Psicologia Comportamental é a única que poderia ser ministrada exclusivamente pelo licenciado em Psicologia.

Pelo nome de tais disciplinas e os cursos aos quais se destinam realizo algumas inferências. Por exemplo, o fato de Ética e Cidadania Organizacional estar presente na maioria dos cursos e levando em consideração que no âmbito dos ideários que regem a educação profissional atualmente está um modelo toyotista de produção - no qual ao profissional não basta mais o domínio das "habilidades técnicas" requeridas para exercer sua função, mas também o domínio das "competências" relacionais requeridas no mundo organizacional - hipotetizo que a função da disciplina e dos conhecimentos psicológicos nela inseridos seja prescrever formas de ser e agir, capturando a subjetividade dos indivíduos e adequando-as àquilo que é considerado como uma conduta ética e cidadã no mundo organizacional. Porém, não se pode desconsiderar que, como visto no primeiro capítulo, uma disciplina nomeada Ética e Cidadania foi inserida no currículo dos cursos técnicos com a finalidade de suprir um défice de formação geral ocasionado pela separação dos cursos propedêutico e profissional.

Já ao refletir sobre a presença da disciplina Psicologia Organizacional no curso técnico de Administração e das disciplinas Psicologia Social e Psicologia Comportamental no curso técnico de Marketing, a primeira hipótese é de que o uso feito da psicologia nesse campo possa privilegiar o ensino de partes desta ciência descontextualizadas do seu arcabouço e visar à sua utilidade imediata, reduzindo a dimensão do saber prático ao uso meramente instrumental, prescritivo do como fazer, servindo a "melhor adequação" dos estudantes ao mercado de trabalho.

Ainda diante das primeiras hipóteses, questiono se a presença do ensino de psicologia nas escolas técnicas não poderia promover espaços de humanização, fissuras e questionamentos numa formação tradicionalmente voltada para o mercado de trabalho e assim como hipotetizamos sobre a disciplina Ética e Cidadania Organizacional, estar imersa numa rede de conflitos e contradições.

No entanto, ainda que o licenciado em Psicologia possa ministrar aula numa diversidade de disciplinas e cursos técnicos das Etecs, o Quadro 1 pouco revela sobre quão representativos os cursos são em termos de número de discentes que o frequentam ou em número de Etecs nas quais estão presentes.

Para prover a dimensão da representatividade desses cursos no conjunto das 
Etecs, realizei um segundo levantamento, porém mais de um ano após a conclusão do primeiro, o que acarretou dificuldades, dadas a rápida expansão da rede de Etecs e de cursos; a volatilidade das transformações de matrizes curriculares e requisitos técnicos para ministrar cada disciplina; e a restrição do acesso ao link outrora público Laboratório de currículo do site www.cpscetec.com.br.

Assim, dados o elevado número de Etecs $(193)^{35}$ e cursos (91) existentes no final do segundo semestre de 2010 e a impossibilidade de refazer o primeiro levantamento por conta da restrição de acesso a informações antes públicas, optei por realizar o segundo levantamento considerando os dados já obtidos e restringir a amplitude da pesquisa a uma amostra composta por: 1) curso que, entre os cursos com disciplinas que podem ser ministradas pelo licenciado em Psicologia, seja um dos dez cursos com maior número de discentes no conjunto das Etecs; 2) curso com mais de uma disciplina que possa ser ministrada pelo licenciado em Psicologia. Ao atender um dos dois critérios apontados, o curso passa a integrar a amostra, composta por 19 cursos. $O$ curso de calçados, ainda que tivesse três disciplinas que o licenciado em Psicologia pudesse ministrar, não compôs a amostra, pois deixou de ser oferecido nas Etecs e no segundo semestre de 2010 não tinha nenhum discente matriculado.

O número de discentes que frequentam cada curso bem como o de Etecs onde os cursos são oferecidos foram construídos com base no segundo semestre de 2010, consultando o site www.cpscetec.com.br/bdcetec/index.php, no período de outubro a dezembro de 2010. Os dados em relação a que cursos possuem disciplinas que podem ser ministradas pelo licenciado em Psicologia foram baseados no levantamento realizado anteriormente, sinteticamente apresentado no Quadro 1.

A Tabela 4 traz a dimensão em termos de números de discentes atendidos nos cursos da amostra. Nessa a primeira coluna à esquerda traz um número de classificação de cada um dos cursos correlacionado à ordem decrescente do número de discentes matriculados nos cursos oferecidos nas Etecs. Foram suprimidos da tabela os cursos que não compuseram a amostra, porém, a existência destes é percebida ao visualizarmos que, por exemplo, o quinto curso (curso de técnico em Enfermagem, que não possui nenhuma disciplina que o licenciado em Psicologia

35 O número de Etecs diverge quanto ao apresentado no primeiro capítulo pois até o segundo semestre de 2010 cinco Etecs, apesar de oficialmente criadas, não tinham ainda nenhum curso oferecido ou discente matriculado. 
possa ministrar) não está nomeado na tabela, mas sua colocação é resguardada em termos de ordem de classificação ${ }^{36}$.

Tabela 4 - Número de discentes por curso e classificação de acordo com os cursos que atendem maior número de discentes no conjunto das Etecs.

\begin{tabular}{|c|c|c|}
\hline Classificação & Curso técnico & Discentes \\
\hline 1 & Administração & 26.141 \\
\hline 2 & Informática & 16.732 \\
\hline 3 & Logística & 10.921 \\
\hline 4 & Contabilidade & 8.023 \\
\hline 7 & Nutrição e dietética & 5.543 \\
\hline 8 & Eletrônica & 5.305 \\
\hline 9 & Secretariado & 4.037 \\
\hline 10 & Química & 3.835 \\
\hline 11 & Informática para internet & 3.765 \\
\hline 12 & Segurança do trabalho & 3.639 \\
\hline 17 & Marketing & 2.124 \\
\hline 21 & Comércio & 1.719 \\
\hline 30 & Agenciamento de viagem & 1.083 \\
\hline 32 & Farmácia & 892 \\
\hline 56 & Agente comunitário de saúde & 262 \\
\hline 59 & Design de móveis & 177 \\
\hline 72 & $\begin{array}{l}\text { Gestão de produção de } \\
\text { enxovais e decoração }\end{array}$ & 75 \\
\hline 84 & Paisagismo & 32 \\
\hline 86 & Saúde bucal & 30 \\
\hline
\end{tabular}

A tabela nos provê uma dimensão em termos de classificação e número bruto de discentes atendidos em cursos com disciplinas que podem ser ministradas pelo licenciado em Psicologia. Uma das coisas que podemos extrair é que entre os dez cursos com mais discentes nas Etecs, apenas dois (cursos de técnico em Enfermagem e Mecânica) não possuem quaisquer disciplinas que possam ser ministradas pelo licenciado em Psicologia.

Ao relacionar esta tabela com o Quadro 1, observo ainda que o curso que

36 Um quadro contendo a totalidade dos cursos atualmente oferecidos nas Etecs, com número de discentes e de disciplinas que podem ser ministradas pelo licenciado em Psicologia encontra-se no Apêndice B. 
possui mais discentes é também o curso que possui mais disciplinas que podem ser ministradas pelo licenciado em Psicologia, o curso técnico em Administração.

A tabela a seguir traz o número de Etecs que oferecem um dado curso e o número de disciplinas que podem ser ministradas pelo licenciado em Psicologia. Ao observá-la é preciso ter clareza:

1. cada Etec oferece uma combinação diversa de cursos. Por exemplo: a Etec Getúlio Vargas, a mais antiga Etec, localizada na região central da cidade de São Paulo, oferece uma diversidade de 12 cursos técnicos só em sua sede, e turmas do curso técnico de Administração em cada uma de suas três extensões ${ }^{37}$, enquanto a Etec de Piedade, autônoma a partir de 2009, localizada no interior paulista, oferece a diversidade de 3 cursos técnicos;

2. cada curso pode ser oferecido para um número diverso de turmas. Por exemplo, na Etec Getúlio Vargas, o curso de técnico em Administração é oferecido para quatro turmas distintas (uma na sede e uma em cada uma de suas extensões), enquanto o curso de Eletrônica é oferecido para três turmas e o curso de Meio Ambiente para uma turma;

3. os cursos oferecidos nas extensões foram contabilizados em suas escolas sedes.

Assim, o número de Etecs que oferecem um dado curso, em sua maioria, será inferior ao número de turmas, as quais não puderam ser contabilizadas no escopo desta pesquisa. Portanto, a Tabela 5 provê uma dimensão em números absolutos de Etecs que oferecem cada curso e quantas disciplinas em cada um podem ser ministradas pelo licenciado em Psicologia. Podemos vislumbrar um considerável campo de atuação para o licenciado em Psicologia frente às Etecs, que se tornará ainda mais explícito ao observarmos o Gráfico 1.

Destaco da Tabela 5 que o curso que possui mais disciplinas que podem ser ministradas pelo licenciado em Psicologia é também o curso que é mais oferecido em termos de número de Etecs e, como vimos na Tabela 4, é o que possui maior número de discentes. Importante lembrar também que neste curso há uma disciplina

37 Várias Etecs possuem extensões. Elas representam cursos oferecidos vinculados administrativamente à Etec sede, porém ministrados em outros locais, como escolas públicas estaduais, Centros Educacionais Unificados (CEUs), prédios cedidos pela prefeitura, entre outros. 
que explicita o ensino de conteúdos psicológicos em seu nome - Psicologia Organizacional.

Tabela 5 - Número de Etecs por curso oferecido e número de disciplinas que o licenciado em Psicologia pode ministrar

\begin{tabular}{lcc}
\hline Curso técnico & $\begin{array}{c}\text { Etecs que } \\
\text { oferecem o } \\
\text { curso }\end{array}$ & $\begin{array}{c}\text { Disciplinas que o } \\
\text { licenciado em Psicologia } \\
\text { pode ministrar }\end{array}$ \\
\hline Administração & 153 & 4 \\
\hline Informática & 128 & 1 \\
\hline Contabilidade & 89 & 1 \\
\hline Logística & 80 & 1 \\
\hline Informática para internet & 60 & 1 \\
\hline Secretariado & 47 & 2 \\
\hline Segurança do trabalho & 41 & 2 \\
\hline Nutrição e dietética & 32 & 1 \\
\hline Marketing & 30 & 3 \\
\hline Comércio & 30 & 1 \\
\hline Eletrônica & 29 & 1 \\
\hline Química & 27 & 2 \\
\hline Agenciamento de viagem & 17 & 2 \\
\hline Agente comunitário de saúde & 7 & 2 \\
\hline Farmácia & 6 & 2 \\
\hline Design de móveis & 1 & 2 \\
\hline Gestão de produção de & 1 & 2 \\
enxovais e decoração & & \\
\hline Paisagismo & 1 & 2 \\
\hline Saúde bucal & 1 & 2 \\
\hline
\end{tabular}

O Gráfico 1 nos auxiliará na compreensão do que representam os números absolutos de Etecs frente ao conjunto das Etecs no estado de São Paulo. Escolhi representar estas escolas em termos de Etecs que possivelmente teriam o maior número de disciplinas que podem ser ministradas pelo licenciado em Psicologia. Para tal separei:

1. Etecs que oferecem conjuntamente os dois cursos que mais possuem disciplinas que podem ser ministradas pelo licenciado em Psicologia, ou seja, o curso de técnico em Administração, com quatro disciplinas, e o curso de técnico em Marketing, com três disciplinas. Estas Etecs também são aquelas que contêm disciplinas que explicitam em seu nome o ensino de conhecimentos psicológicos. Há 26 Etecs que 
atendem a este critério, as quais representam $13 \%$ do total de Etecs do estado;

2. Etecs que oferecem o curso de técnico em Administração, por se tratar do curso que mais oferece disciplinas que podem ser ministradas pelo licenciado em Psicologia, dentre elas a disciplina Psicologia Organizacional. Há 127 Etecs com tal característica, as quais representam $66 \%$ do total de Etecs do estado;

3. Etecs que oferecem o curso de técnico em Marketing, por se tratar do segundo curso que mais oferece disciplinas que podem ser ministradas pelo licenciado em Psicologia, dentre elas as disciplinas Psicologia Comportamental e Psicologia Social. Há quatro Etecs com essa característica, as quais representam $2 \%$ do total de Etecs do estado;

4. Etecs que oferecem ao menos um dos outros cursos que compuseram a amostra, tendo assim no mínimo uma disciplina que pode ser ministrada pelo licenciado em Psicologia. Há 29 Etecs com esta característica, as quais representam $15 \%$ do total de Etecs do estado;

5. Etecs que não oferecem nenhum dos cursos que compõem a amostra. Como eram apenas sete Etecs, que representam 4\% do total de Etecs do estado, pesquisei os cursos oferecidos por estas escolas, e em todas havia pelo menos um curso com uma disciplina que pudesse ser ministrada pelo licenciado em Psicologia.

Pelo Gráfico 1 podemos visualizar que somadas todas as Etecs que oferecem disciplinas que explicitem o ensino de conteúdos psicológicos em seu nome temos 157 escolas, ou seja, 81\% das Etecs. Além disto, 30 Etecs $-15 \%$ do total de Etecs do estado - possui o curso de técnico em Marketing e, assim, a disciplina que é de exclusividade do licenciado em Psicologia ministrar, qual seja, Psicologia Comportamental. Por fim, todas as Etecs tem ao menos um curso com uma disciplina que pode ser ministrada pelo licenciado em Psicologia. Ou seja, em termos de número e porcentagem de Etecs nas quais o licenciado em psicologia pode ministrar aulas, há um amplo espaço para sua atuação. 
Gráfico 1 - Número e porcentagem de Etecs por cursos oferecidos ${ }^{38}$

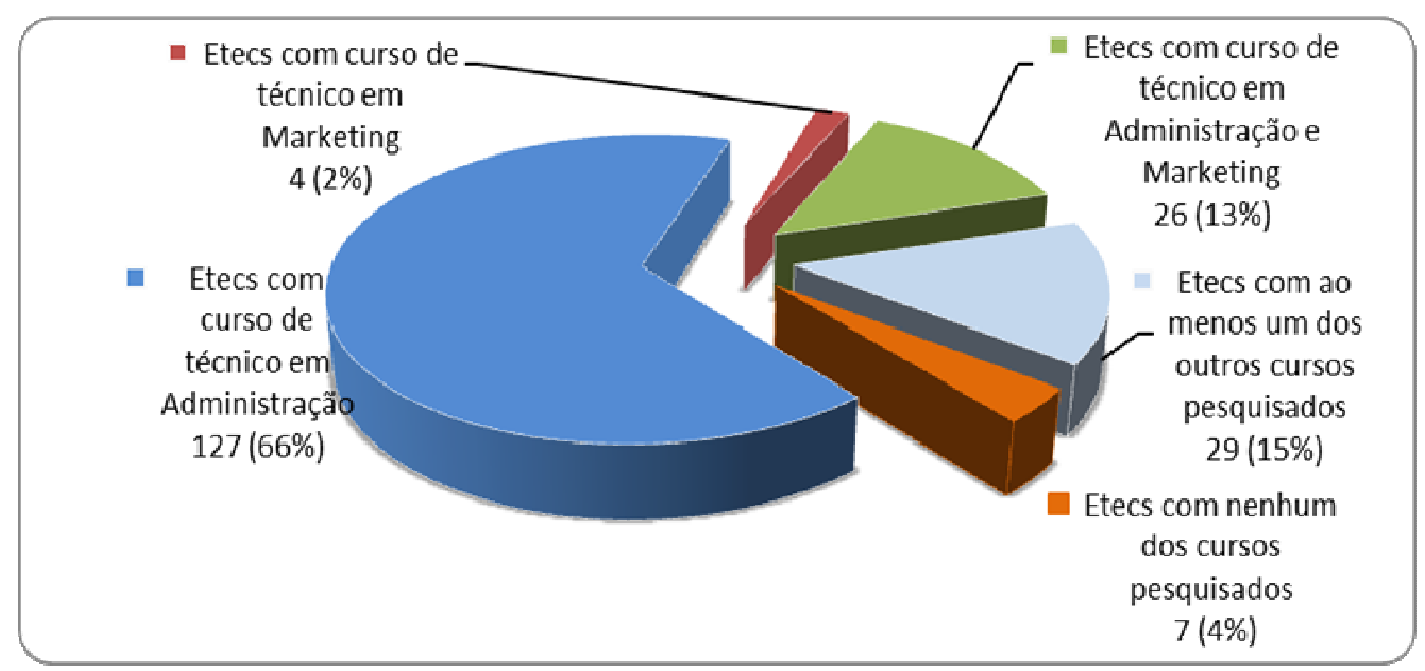

Concluo que os dados, ainda que amostrais, nos dão uma dimensão do quanto o licenciado em Psicologia (e assim os conhecimentos psicológicos) pode estar presente nas Etecs.

Porém, tais dados me suscitam mais dúvidas do que esclarecimentos, pois me instigam a questionar porque e qual psicologia é apropriada no campo das Etecs. Considero que para tentar responder a essas perguntas é preciso conhecer mais de perto o campo do ensino de psicologia nas Etecs, visto ser o mesmo ainda inexplorado, carente de pesquisa e reflexão. O caminho escolhido para conhecer este campo e atingir aos objetivos da pesquisa aqui proposta estará explicitado no próximo capítulo.

38 Cabe observar que todas as 193 Etecs que estavam em funcionamento no segundo semestre de 2010 ofereciam algum curso com disciplina que o licenciado em Psicologia pode ministrar. 


\section{MÉTODO}

\subsection{Esclarecimentos preliminares: dos objetivos e concepções que orientaram a construção do método}

Ao deparar-me com um amplo campo de possibilidades de atuação para o licenciado em Psicologia frente às Etecs, porém com poucos elementos de pesquisas já realizadas ou mesmo de experiência pessoal nesse campo que me possibilitasse compreendê-lo, escolhi problematizá-lo a partir da realidade de uma escola técnica estadual.

Estabeleci como objetivo conhecer e discutir as contribuições do ensino de psicologia no campo das Escolas Técnicas Estaduais de São Paulo, buscando nos objetivos específicos conhecer e discutir: quais os conteúdos ensinados nas disciplinas de psicologia e seus objetivos; como os estudantes interagem com os conteúdos da disciplina e como ela contribui para sua formação pessoal e profissional; qual a relação dos objetivos e conteúdos ensinados nessas disciplinas com o perfil do profissional que se pretende formar; e a atuação do professor de psicologia no campo das Etecs.

Por todo o caminho percorrido no desenvolvimento do tema na construção dos objetivos da pesquisa até as formas possíveis de alcançá-los, fui fortalecendo uma impressão inicial de que desenvolveria uma pesquisa qualitativa. Entretanto, ao recorrer a textos que fundamentam teoricamente o que seria uma pesquisa qualitativa, pude ver por Becker (1999) que a pesquisa qualitativa surge e se funda numa oposição aos métodos chamados quantitativos por estes terem uma concepção a priori de pesquisa e buscarem por meio da técnica controlar efeitos ditos indesejáveis sobre os resultados. Bogdan e Biklen (1994) elencam ainda cinco características que definiriam uma pesquisa como qualitativa, mas mesmo segundo os autores alguns estudos qualitativos poderiam ser totalmente desprovidos de algumas dessas características. Denzin e Lincoln (2006) apontam que a pesquisa qualitativa tem um significado diferente em cada momento histórico, e que convivem na atualidade fundamentos dos mais diversos que as orientam, desde fundacionalismo, positivismo, pós-fundacionalismo, pós-positivismo, entre outros, aos quais Bogdan e Biklen (1994) acrescentam os autores pós-modernos. Para Denzin e Lincoln (2006), 
Três atividades genéricas, interligadas, definem o processo de pesquisa qualitativa. Elas seguem uma variedade de rótulos diferentes, incluindo os da teoria, método, análise, ontologia, epistemologia e metodologia. Por trás desses termos, está a biografia pessoal do pesquisador, o qual fala a partir de uma determinada perspectiva de classe, de gênero, de raça, de cultura e de comunidade étnica. Esse pesquisador, marcado pelo gênero, situado em múltiplas culturas, aborda o mundo com um conjunto de idéias, um esquema (teoria, ontologia) que especifica uma série de questões (epistemologia) que ele então examina em aspectos específicos (metodologia, análise). (p. 32, grifo dos autores)

Diante deste quadro, compreendo que se a união de diversas formas de se fazer pesquisa sob a denominação de pesquisa qualitativa serviu historicamente para se contrapor a um modelo hegemônico de pesquisa - derivado das ciências naturais e orientado por um paradigma positivista - buscando a legitimação da cientificidade de seus métodos de investigação, parece-me que atualmente tal distinção se tornou demasiado plástica, a ponto de mesmo pesquisas ditas qualitativas poderem ser orientadas pelo paradigma positivista. Estabelecendo a necessidade de explicitação do lugar pessoal, teórico, epistemológico e metodológico do qual o pesquisador fala, o que entendo, seria necessário tanto a pesquisas ditas qualitativas quanto quantitativas.

Assim a definição de pesquisa qualitativa e quantitativa hoje efetivamente não marca uma distinção, a ponto de Rey (2005) chegar a propor a distinção em termos de uma "epistemologia qualitativa", baseada em três princípios (conhecimento como produção construtivo-interpretativa, caráter interativo do processo de produção do conhecimento e significação da singularidade como nível legítimo de produção de conhecimento), os quais também estariam presentes numa pesquisa que utiliza métodos caracterizados como quantitativos (como o próprio autor aponta em relação a autores que desenvolvem pesquisas ditas quantitativas com criticidade).

Diante dessas questões e a partir de uma perspectiva materialista históricodialética, continuar a enquadrar pesquisas como quantitativas ou qualitativas é persistir na reprodução de dicotomias, que no fundo carregam a dicotomia sujeito $x$ objeto, subjetividade $\times$ objetividade, o que, conforme aponta Martins (2006), revela a superação apenas aparente da lógica positivista, posto que atende a um de seus princípios basilares, a lógica da exclusão. A partir da lógica dialética, compreende-se o mundo a partir da identidade dos contrários e da unidade indissolúvel dos opostos, não fazendo sentido dicotomizar e preterir qualquer um dos polos em detrimento do outro, entendendo-se, por exemplo, o subjetivo como objetivo e o objetivo como 
subjetivo. O conhecimento é entendido como uma subjetivação objetivada ao mesmo tempo que uma objetivação subjetivada, não cabendo a prevalência nem do sujeito nem do objeto, tampouco a generalização desse conhecimento, mas sim do que podemos aprender de uma estrutura mais geral por meio de um caso singular (MARTINS, 2006), conforme pontuarei a seguir.

Por todo o exposto penso que, se há uma distinção de método de pesquisa possível, esta é a explicitação minuciosa das escolhas pessoais e teóricas do pesquisador, de como elas intervêm no estudo do seu tema e de quais foram os limites e possibilidades que proporcionaram em sua relação com o campo. Ao mesmo tempo acrescento ser necessário explicitar ao máximo as características fenomênicas do que será alvo de nosso olhar e como elas também determinam o processo de pesquisa, pois ao ater-se a apenas uma dessas condições recoloca-se sob bases atualizadas a dicotomia sujeito-objeto, subjetividade-objetividade. Como aponta Gonçalves (2005), corre-se o risco de o sujeito ser tão ampliado em suas possibilidades que se esvanece, e se considera o conhecimento como construído apenas pelo sujeito, independente das características do objeto; ou no extremo oposto, do objeto ser tomado como tão diverso que é relativizado, ou mesmo do conhecimento ser determinado de modo inexorável pelas características também inexoráveis da realidade.

Entendo que tais riscos são superados na afirmação da unidade epistemológica, ontológica e metodológica do Materialismo Histórico-Dialético, visto que nesta a realidade não é dicotomizada, mas relacional. Ela também nos coloca a necessidade de descrever o mais detalhadamente possível os procedimentos a serem utilizados, relacionando a escolha dos mesmos ao tema e aos pressupostos do pesquisador, proporcionando assim, a partir de seu fazer, o necessário e profícuo diálogo com outras orientações teóricas, que podem já ter examinado o mesmo tema de pesquisa, ou mesmo determinadas questões que perpassam certos procedimentos. Eximir-se de percorrer este caminho poderia levar a um isolamento e em última instância uma fetichização da teoria, à medida que, ao fechar-se em si mesma, afirma um modelo "mágico" e "único" de ciência que busca impor-se, o que foi extenuantemente criticado sobre o positivismo.

Assim, ao invés de aprisionar o método a ser realizado em classificações desgastadas e incoerentes com os pressupostos epistêmico-metodológicos que orientam a pesquisa, optei por explicitar quais foram as escolhas feitas para a 
construção do método, justificadas pela orientação teórica bem como pelas características fenomênicas do que se quer estudar e dos objetivos que a pesquisa se propôs a investigar.

\subsection{Pressupostos epistêmico-metodológicos e características do tema de estudo}

Para o Materialismo Histórico-Dialético, o conhecimento se constrói no movimento contínuo fenômeno-abstrações teóricas-concretude. O fenômeno é o que percebemos imediata e diretamente (KOSIK, 1976) e, segundo Martins (2006), são "representações primárias decorrentes de suas projeções na consciência dos homens" (p. 10). As abstrações teóricas são o movimento de distanciamento dessa manifestação fenomênica a partir da análise do próprio fenômeno e também de construções teóricas já realizadas, desvelando suas mediações, leis e contradições internas. E a concretude seria a união do mundo fenomênico refletido por meio das abstrações teóricas e exegese analítica que retorna ao mundo fenomênico e o ressignifica (KOSIK, 1976).

Segundo Oliveira (2005), para apreender a concretude do fenômeno, as categorias que nos auxiliam são singular-particular-universal em seu movimento e unicidade. Nessa compreensão, singular e universal são polos de uma relação mediada pelo particular, na qual, didaticamente:

- $\quad$ singular diz respeito à manifestação única, síntese social complexa na qual se concretiza histórica e socialmente a universalidade com a mediação da particularidade, por meio do trabalho enquanto atividade humana orientada para produzir valores de $u^{30}{ }^{39}$.

- $\quad$ particular se constitui em mediações que explicam os mecanismos que interferem decisivamente no modo de ser da singularidade. Diz respeito ao que é partilhado entre pessoas e que se concretiza em circunstâncias específicas das relações entre universal e singular.

- universal diz respeito às regularidades, às leis e formas presentes no processo, bem como compreende as possibilidades por vezes não concretizadas devido à forma de organização social na qual vivemos,

39 Para uma explicação didática e esclarecedora sobre o que é valor de uso, recomendo Carone (2005). 
"uma abstração que tem sua base concreta na própria realidade" (OLIVEIRA, 2005, p. 28).

As categorias singular-particular-universal são construídas em interação e sua caracterização depende da delimitação da problemática estudada. Um único fenômeno contém a singularidade, a particularidade e a universalidade. "O singular, portanto, não existe em si e por si, mas somente em sua relação intrínseca com o universal que se faz somente através de mediações - o particular. Por outro lado o universal só existe quando se concretiza no singular" (OLIVEIRA, 2005, p. 50).

Numa exposição didática, diria que no tema de pesquisa desta dissertação, a forma única como se expressa o ensino de psicologia numa escola técnica seria a singularidade, que se relaciona com a universalidade das políticas globais de educação por meio da concretização específica dessas políticas nas Etecs (particularidade). Nesse movimento se revela a universalidade contida na expressão singular estudada, a qual apontará para limites e possibilidades do ensino de psicologia nas Etecs, relacionando-os ao contexto social, as políticas públicas e aos conhecimentos sobre psicologia e educação que por ora não tenham conseguido hegemonia para se expressar como políticas públicas.

Porém, tais categorias não existem para realizar uma classificação estanque em agrupamentos, ainda que didaticamente tenham sido feitos, mas são utilizadas para esclarecer níveis diferenciados de análise e o movimento intrínseco às suas relações, a fim de assegurar a compreensão de uma dada problemática.

Para tal, segundo Oliveira (2005), é preciso ainda considerar as manifestações fenomênicas mais imediatas como ponto de partida e chegada da investigação e ultrapassá-las, conhecendo as raízes processuais que formam a universalidade onde tais manifestações são produzidas, identificando e caracterizando as "condições histórico-sociais que determinam seu modo de ser e suas transformações histórico-sociais para formular determinada lei e respectiva categoria que represente a singularidade, a particularidade e a universalidade de determinado processo" (p. 40).

Numa problemática como a desta pesquisa - em que o campo do ensino de psicologia em escolas técnicas é inexplorado, carente de pesquisas e reflexões; que busca conhecer e discutir as contribuições do mesmo; e que para além das aproximações teóricas que fiz em relação ao campo, nada conheço de sua expressão fenomênica -, a forma encontrada para compreendê-la, orientada por tais 
características, bem como pela perspectiva teórica, foi aproximar-me da expressão fenomênica do ensino de psicologia em escolas técnicas, de forma profunda e ao mesmo tempo abrangente. Para tal busquei conhecer uma escola técnica, expressão particular das escolas técnicas, em sua singularidade.

Segundo Martins (2005), o método materialista histórico-dialético afirma a legitimidade da produção do conhecimento a partir da singularidade, visto que expressa aspectos da universalidade pela mediação do particular, tendo por objetivo apreender a concretude do fenômeno estudado.

\subsection{A escolha do campo}

Com tais pressupostos embasando o trabalho, busquei uma escola técnica estadual na qual existe o ensino de psicologia. Como vimos, em todas as escolas técnicas seria possível existirem licenciados em psicologia ministrando aulas. Assim, foi necessário eleger critérios de seleção para a escolha da instituição a ser estudada. Delimitei que pesquisaria na cidade de São Paulo, pois a pesquisa envolveria grande frequência ao campo. Defini então que as disciplinas que explicitam em seus nomes o abordar de conhecimentos psicológicos seriam um local privilegiado para estudo das contribuições que o ensino de psicologia possa trazer no campo das Etecs. Por este critério, cheguei aos cursos de técnico em Administração e técnico em Marketing, que são compostos respectivamente pelas disciplinas Psicologia Organizacional, e Psicologia Comportamental e Psicologia Social. Para possibilitar o desenvolvimento da pesquisa, elegi como campo privilegiado uma escola com os dois cursos e que fosse uma escola já consolidada, oferecendo tais cursos no mínimo desde o primeiro semestre de 2009, pois as disciplinas elegidas como campo privilegiado de observação são oferecidas em diferentes momentos dos cursos (a disciplina Psicologia Organizacional é oferecida no primeiro módulo ${ }^{40}$ do curso de técnico em Administração, enquanto as disciplinas Psicologia Comportamental e Psicologia Social são oferecidas respectivamente no segundo e terceiro módulo do curso de técnico em Marketing).

40 As escolas técnicas estaduais têm sua estrutura curricular organizada por módulos, sendo que cada módulo tem a duração de um semestre e pode ou não ao final do mesmo dar direito a uma certificação técnica. Ex: o curso de técnico em Administração é organizado em 3 módulos. Ao concluir o segundo módulo, o discente é certificado com "qualificação técnica de nível médio de Assistente Administrativo" e, ao concluir o terceiro módulo, é certificado com "habilitação profissional técnica de nível médio de técnico em Administração". 
Além disso, a disciplina de Psicologia Comportamental é a única que pode ser ministrada somente por licenciados em Psicologia ${ }^{41}$ o que, considerei, aumentava as chances das outras disciplinas que contemplem psicologia em seu nome também serem ministradas por profissional com tal formação.

Diante de todos esses critérios, cheguei a uma possível instituição, com a qual negociei a realização da pesquisa e a utilização ou não de cada um dos procedimentos elencados. Como descreverei a seguir, partes de alguns procedimentos foram excluídas ou modificadas no processo de negociação com os sujeitos envolvidos na pesquisa, o que é consistente com o que Chataway (2001) aponta sobre o processo de negociação.

Após a diretora da Etec e um docente (que a partir deste momento será identificado como Vinícius ${ }^{42}$ ) aceitarem a realização da pesquisa, ambos leram, preencheram e assinaram documentos consentindo quanto à realização da mesma. À diretora coube a assinatura da "Carta de autorização para a realização da pesquisa" (Apêndice C) e a Vinícius o "Termo de consentimento livre e esclarecido" (Apêndice D).

\subsection{Procedimentos}

\subsubsection{Observações em aula e dos espaços comuns da escola}

Um dos procedimentos de pesquisa elencado foi a observação de aulas das disciplinas Psicologia Organizacional (curso técnico de Administração) e Psicologia Comportamental e Psicologia Social (curso técnico de Marketing). Este procedimento foi escolhido por possibilitar conhecer a expressão fenomênica das disciplinas e seus conteúdos no momento em que são ministradas, além de como os discentes interagem com estes. E ainda, conhecer a atuação do professor de psicologia numa Escola Técnica Estadual.

41 A disciplina Psicologia Organizacional do curso de técnico em Administração pode ser ministrada por graduados em Administração, Ciências Administrativas e Psicologia. Já a disciplina Psicologia Social do curso de técnico em Marketing pode ser ministrada por graduados em Ciências Sociais, Sociologia, Sociologia e Política, e Psicologia (conforme www.cpscetec.com.br/crt).

42 Nome fictício escolhido por mim a fim de preservar a identidade do docente das disciplinas observadas. 
No processo de negociação com a escola, a coordenadora estabeleceu que primeiramente ela conversaria com os docentes das disciplinas, apresentaria em linhas gerais a proposta da pesquisa e os convidaria a conversarem comigo, sem compromissos, o que para mim denotou respeito por parte da escola em relação à autonomia do docente sobre sua sala de aula.

Vinícius, docente das disciplinas Psicologia Organizacional e Psicologia Social, aceitou o convite e a realização da pesquisa. Já a docente da disciplina de Psicologia Comportamental não aceitou o convite para uma primeira conversa. Durante o processo de pesquisa não tive a oportunidade de conhecer a professora tendo em vista que meus períodos de observação não coincidiam com seus períodos de aula, mas hipotetizo que sua recusa esteja relacionada ao fato de a docente não possuir qualquer formação em Psicologia e que ministrava tal aula em caráter excepcional, substituindo o docente que se encontrava afastado das aulas por ter assumido a função de coordenador em outra $\mathrm{Etec}^{43}$. Tais fatores, entendo, podem tanto não ter despertado o interesse da docente para o tema da pesquisa, quanto tê-la deixado receosa, pois não tinha a formação necessária para ministrar a disciplina, a qual seria a única de exclusividade do licenciado em Psicologia. Isso limitou a abrangência da pesquisa em relação às observações, pois considerei que procurar uma outra Etec para observar tal disciplina não seria viável. Restringi então a observação às aulas de Psicologia Organizacional e Psicologia Social.

Durante as aulas, as questões observadas foram relação Vinícius-discentes, conteúdo e mediações feitas por Vinícius ao ministrá-lo, modo como discentes interagem com o conteúdo e materiais utilizados por Vinícius.

Ainda que tenha delimitado a priori as observações das aulas, nos momentos em que se estive na escola pude observar ainda o horário de intervalo na sala dos professores, um conselho de classe, uma reunião de pais do curso técnico de Administração e o período de ensaio para a apresentação do Trabalho de Conclusão de Curso da turma de técnico em Marketing. Tais observações foram fundamentais para compreender questões e práticas institucionais que perpassam as práticas em sala de aula, mas que não necessariamente se restringem a ela, como por exemplo:

43 Nas Etecs existem diferentes modalidades de coordenação, algumas com afastamento total da sala de aula e outras não. Vinícius estava afastado como coordenador de área de um dos cursos de outra Etec e nessa condição se afastou de dez aulas, dentre elas as da disciplina de Psicologia Comportamental na Etec observada. 
a forma como se organizam as escolas técnicas estaduais, a relação entre a equipe escolar e desta com os discentes, o grau de autonomia dos professores e o discurso institucional acerca da formação técnica.

As observações, seja das aulas ou dos espaços comuns, foram realizadas no decorrer do segundo semestre de 2010, totalizando 68 horas e 45 minutos de observação, distribuídas em uma visita semanal à instituição de duração média de quatro horas. Ainda que tenha considerado que um período tão longo de tempo num mesmo dia na escola não seria a condição de observação ideal para os objetivos do estudo, foi a que se fez possível, tendo em vista que Vinícius ministrava as disciplinas elegidas nesse período.

Minha postura nos períodos de observação foi investigativa e de disposição colaborativa. Na maior parte dos períodos de aula, eu observava e tomava nota dos acontecimentos em sala, tentando equilibrar o que anotava - em relação ao conteúdo, mediações de Vinícius e postura geral dos discentes em sala de aula com as possibilidades de observar e anotar como eu me sentia diante das situações. Isso foi importante, pois ao identificar meus sentimentos de alegria, surpresa ou desconforto, pude refleti-los a ponto de me forneceram pistas do que seria importante estar contido na análise e o que deveria ser suprimido por só ter relevância para mim e não para os objetivos da pesquisa.

Quando Vinícius propunha a realização de atividades em grupo, solicitava que eu participasse junto aos discentes, pois segundo o mesmo, "na sala dele todos têm de participar". Esses espaços foram ricos ao possibilitar que eu observasse a postura dos discentes em relação às atividades e sua compreensão acerca do conteúdo. Diante das solicitações dos discentes por respostas certas, busquei produzir perguntas a partir de suas respostas.

Como esperado, minha presença, um ser a princípio estranho à dinâmica da instituição, produziu modificações. Isso pode ser observado no quase absoluto silêncio da sala dos professores nos primeiros dias que eu a frequentei e em algumas falas de Vinícius, que me explicitavam os motivos de algumas de suas ações ou expressavam seu desconforto com alguém observando e tomando notas em sua aula. Como exemplos, cito que durante uma dada aula Vinícius disse "claro que ter alguém anotando produz um sentimento persecutório" e olhou para mim; num outro dado momento disse "não sou o dono da verdade, e não gostaria que me interpretassem assim. Já tive problemas sendo visto assim”. Considerei 
importante que ele pudesse expressar tais sentimentos e que eu pudesse esclarecer que eu não estava ali para avaliá-lo como bom ou mau professor e que provavelmente não me sentiria inteiramente confortável se a situação fosse oposta. O interessante é que mesmo ele se sentindo assim continuava abrindo o espaço de suas aulas para estagiários e pesquisadores.

Como procedimento de registro, utilizei o diário de campo, composto por notas realizadas durante os períodos de permanência na instituição, ampliadas o mais rápido possível de cada dia de observação. Busquei formalizar textualmente o observado, buscando o que Geertz (1989) nomeia como descrição densa, uma descrição com o máximo de detalhes que ao mesmo tempo explicite as funções do que está sendo descrito. Como nos lembra Rockwell (2009a), mesmo essa descrição já é produto de um trabalho analítico conceitual, que precisa estar explícito. Como exemplificado acima, busquei também incorporar na descrição elementos tanto das interações entre os sujeitos que constituem a instituição quanto deles comigo, abarcando ainda os aspectos subjetivos a que tais interações estão sujeitas e/ou provocam.

Após essa primeira descrição (fruto das notas de campo ampliadas), realizei aquilo que Martins (2006) nomeou como exegese analítica, à qual Rockwell (2009a) se referirá como intenso trabalho de elaboração teórica. Tal trabalho é fundamental, e é por isto que a autora adverte que "las horas de trabajo de campo no conducen al conocimiento si no se acompañan de un trabajo teórico y analítico que permita modificar, y no solo confirmar, las concepciones iniciales acerca de la localidad y del objeto estudiado" (p. 43-44). Esse foi um dos aspectos considerados para a decisão de não ampliar para mais uma instituição o campo, ainda que tenha significado não observar as aulas de Psicologia Comportamental.

Para fazer tal exegese analítica, busquei debruçar-me repetidamente sobre as notas e registros de campo, atrelado a um intenso trabalho teórico de busca e estudo de referências e conceitos que auxiliaram a compreensão de detalhes e indícios a princípio não significados, ultrapassando a expressão empírica dos mesmos, chegando a sua expressão concreta.

No entanto, a análise abrangeu não apenas os frutos das observações, mas de todos os procedimentos, significando-os em seu conjunto, dos quais extraiuse categorias, conforme explicitarei após a apresentação de todos os procedimentos realizados na pesquisa. 


\subsubsection{Análise de documentos}

Esse procedimento teve por objetivo conhecer o que preconizam os documentos que regem a atuação dos docentes de psicologia nas Etecs. Os documentos analisados foram elegidos a partir de conversas com Vinícius. A partir de tais conversas, entendi que os documentos que orientam sua prática são: Plano Plurianual de Gestão 2009-2013, Plano de Curso de Técnico em Administração, Plano de Curso de Técnico em Marketing, Plano de Trabalho Docente - disciplina de Psicologia Organizacional e Plano de Trabalho Docente - disciplina de Psicologia Social. Além de tais documentos orientadores da prática docente, foram analisados os quatro textos que Vinícius utilizou em sala de aula como recurso didático para os discentes.

Para a análise dos documentos, além de seu conteúdo, foi importante saber por quem, com quais objetivos e como os mesmos foram elaborados, pois como diz Rockwell (2009b), "La distancia entre norma y práctica puede ser mayor o menor, dependiendo de su forma de producción e circulación" (p. 173), e "no siempre es válido suponer que sus orientaciones se traducían en prácticas en las aulas" ( $p$. 174). Assim, a análise desses documentos e a busca pela forma como se fazem ou não presentes na prática do professor de psicologia teve nesta pesquisa como objetivo investigar se e quais limites e possibilidades os conteúdos e as normas expressas nos mesmos trazem à prática cotidiana em sala de aula. Ainda que como primeiro passo tenha feito uma análise atenta dos conteúdos e concepções que tais documentos trazem de forma explícita ou implícita, para os objetivos desta pesquisa os mesmos foram significados em conjunto com os outros procedimentos investigativos.

Como uma parte da pesquisa buscava conhecer um pouco o perfil dos discentes das escolas técnicas estaduais de São Paulo - e a Etec campo desta pesquisa não dispunha destas informações sistematizadas - incluí na análise documental a realização de levantamento para a caracterização dos discentes com base na documentação da escola. A coordenação da Etec me possibilitou acesso às listas de chamada de todas as turmas da escola - que continham sexo e data de nascimento dos discentes - e aos prontuários dos discentes dos cursos técnicos de Administração e Marketing, nos quais em sua maioria era possível obter os dados sobre as instituições em que cursam (ou cursaram) o ensino médio propedêutico. 
Realizei ainda o levantamento das instituições nas quais os discentes dos cursos técnicos de Administração e Marketing cursaram o ensino fundamental, porém observei que em torno de $35 \%$ dos prontuários esta informação não existia, por isto optei por não explicitá-la na caracterização dos discentes.

As informações sobre sexo, faixa etária e procedência escolar foram levantadas com o objetivo de conhecer alguns aspectos do perfil dos discentes da escola. A princípio gostaria de ter ainda os dados sobre a ocupação profissional dos discentes, porém a escola não dispunha de fontes para a construção desta informação. Também gostaria de ter as informações sobre a procedência dos discentes de todos os cursos da escola, porém considerei inviável fazê-lo. Optei por restringir o levantamento aos cursos referentes às disciplinas observadas.

Para análise das informações, agrupei-as em termos de sexo e faixas etárias, as quais utilizaram por referências as faixas etárias utilizadas no Censo Escolar Sinopse Estatística da Educação Básica, no que se refere aos dados da Educação Profissional (BRASIL, 2009c). Em relação à procedência dos discentes, as escolas foram classificadas em escolas públicas ${ }^{44}$ e privadas. No caso do ensino médio propedêutico cursado em escola pública, distinguiu-se entre os que a cursam na Etec campo da pesquisa, em outra Etec ou em escola pública do sistema propedêutico de ensino. Também se distinguiu entre os que estão cursando o ensino médio propedêutico concomitantemente ou aqueles que já o concluíram e cursam o ensino técnico subsequentemente.

As informações sobre perfil dos discentes auxiliaram a compor a caracterização da escola campo desta pesquisa, explicitada no item 3.5.2.

\subsubsection{Conversas informais e conversa formal}

Para aprofundar, detalhar e mesmo discutir com Vinícius as dúvidas e reflexões que foram sendo construídas no movimento de observação, análise documental e elaboração teórica, foram realizadas conversas informais no curso da pesquisa e uma conversa formal no encerramento. Especialmente na conversa

44 Escolas públicas são aquelas criadas e mantidas pelo poder público federal, estadual, municipal ou do Distrito Federal. Escolas vinculadas a cooperativas, fundações, Sistema S (Serviço Social da Indústria - SESI; Serviço Nacional de Aprendizagem Comercial SENAC; Serviço Social do Comércio - SESC; SENAI), entre outras, embora gratuitas, não são públicas, devido à dependência administrativa do setor privado. 
formal busquei abarcar aspectos que os procedimentos realizados anteriormente não foram capazes de abranger.

As conversas informais foram ocorrendo no dia a dia da pesquisa, ou com Vinícius espontaneamente explicitando questões, ou comigo solicitando alguns esclarecimentos.

Como pontua Rey (2005, p. 85-87) a pesquisa gera diálogos formais e informais entre os sujeitos, os quais têm muita importância e são parte essencial do processo de pesquisa. É por meio deles que se estabelece colaboração e participação entre os sujeitos e destes com a pesquisa e se estabelece uma atmosfera humanizada que se aproxima da trama de relações que ocorrem cotidianamente no campo pesquisado. Por tais questões o autor afirma que tais diálogos convertem-se em fonte importante de informação sobre o problema estudado, o que ocorreu no processo desta pesquisa.

Algumas questões abordadas nas conversas foram: a formação profissional de Vinícius, suas atividades profissionais, formas como foram elaborados os documentos que orientam a prática docente nas Etecs, considerações de Vinícuis sobre as contribuições que as disciplinas observadas podem trazer à formação de seus estudantes, o processo de pesquisa, a dinâmica das aulas, o processo de tornar- se professor, o Centro Paula Souza em relação à formação contínua de Vinícius, o trabalho de Vinícius como coordenador, o meu processo no mestrado, entre outros.

A conversa formal foi realizada no último dia de observação, quando não havia mais discentes na escola, numa sala de aula, e teve duração de 58 minutos. Foi uma entrevista semiestruturada, com alguns tópicos para conversa préformulados, que foram: o processo de tornar-se professor; comparação entre objetivos e conteúdos de psicologia ministrados no ensino médio propedêutico e no ensino técnico; critérios de seleção dos conteúdos das disciplinas observadas; que contribuições Vinícius entende que as disciplinas observadas podem trazer à formação de seus estudantes; o processo de escolha dos autores utilizados como referência em aula; questões de dúvidas específicas quanto à interpretação dos Planos de Trabalho Docente; autoria dos textos utilizados por Vinícius como recurso didático. Surgiram ainda questões sobre o relacionamento entre docentes de uma mesma disciplina, considerações e críticas de Vinícius ao Centro Paula Souza e a relação ensino-aprendizagem e docente-discente. 
O registro das conversas informais foi realizado por meio das notas e diário de campo, junto ao conjunto da observação. No caso da entrevista, foi gravada em áudio com consentimento de Vinícius, o qual não se mostrou desconfortável com a utilização do recurso. A entrevista foi posteriormente transcrita.

Como todos os outros procedimentos propostos, a análise das conversas informais e da entrevista também foi realizada considerando o conjunto do processo de pesquisa.

3.4.4. Processo de pesquisa e análise que perpassa o conjunto de procedimentos elencados

Até o momento apresentei e justifiquei os procedimentos utilizados para a realização da pesquisa. A diversidade dos procedimentos realizados buscaram construir em uma dimensão ampla a forma como se manifesta empiricamente o processo do ensino de psicologia em uma escola técnica, sendo que os procedimentos não se constituíram como um fim em si mesmos, isolados do curso geral da pesquisa e dos processos que nela se desenvolvem, conforme propõe Rey (2005, p. 84).

Para além das formas de análise já explicitadas em alguns procedimentos específicos, houve um olhar que perpassou o processo de pesquisa tanto em seus momentos de execução quanto os de análise, que envolvem uma determinada postura - considerada na pesquisa como um todo.

Esse olhar e postura em parte decorrem da escolha pela orientação do Materialismo Histórico-Dialético, em especial que por meio de tais procedimentos se teve primariamente acesso ao fenômeno, e em articulação com a exegese analítica, busquei a concretude do mesmo em suas expressões singulares, particulares e universais.

Entendi ainda como importante levar em consideração as diversas problematizações produzidas por outros pesquisadores no que diz respeito ao estar no campo e ao que fazer com o que se consegue apreender dele.

A primeira problematização importante é que, dado o desconhecimento que se tem em relação ao ensino de psicologia em escolas técnicas, foi preciso um esforço intelectual de abertura aos detalhes e fragmentos da vida cotidiana dos sujeitos da pesquisa no contexto que a mesma ocorreu, ainda que à primeira vista 
os julgasse irrelevantes ou que não relacionados diretamente ao tema. Como aponta Rockwell (2009a, p. 54) "se insiste en observar todo, aunque de hecho esto sea imposible".

Outra discussão trazida pela autora é a necessidade de considerar que o processo de pesquisa é atravessado pela subjetividade dos sujeitos envolvidos, suas angústias, suas defesas, fascinação, curiosidade, o que escolhem mostrar ou ocultar, as relações intersubjetivas estabelecidas. Ao reconhecer tal dimensão é possível verificar seus efeitos sobre a observação e interpretação que todos os envolvidos fazem do processo de pesquisa, bem como as modificações que a dimensão subjetiva produz na realidade empírica.

Ao esforço intelectual de observação e reconhecimento do lugar da subjetividade, somou-se o trabalho de análise propriamente dito. Há diversas formas de proceder a esta análise, mas destaco a busca pelo que Rockwell (2009a) nomeia como construção de categorias sociais e analíticas, bem como a explicitação do modo como elas se relacionam. Categorias sociais são, como entendidas pela autora, aquelas que aparecem no discurso e nas ações dos sujeitos do local onde se faz a pesquisa e estabelecem distinções próprias sobre a realidade que vivem, sendo algumas delas possíveis de serem reconhecidas como conhecimento legítimo que os mesmos tem sobre tal local, podendo o processo de análise manter categorias sociais que indiquem distinções e características importantes, ainda que não previstas na teoria nem pelo investigador, e poder futuramente ser incorporadas pela teoria. Já as categorias analíticas podem abarcar algumas categorias sociais, mas as transcendem, por captarem e expressarem diferenças sociais de fundo e serem dadas por uma compreensão teórica, que no caso desta pesquisa é a do Materialismo Histórico-Dialético. No caso da pesquisa realizada, ainda que tenha levado em consideração a possibilidade de existirem categorias sociais, o processo de análise revelou apenas categorias analíticas.

Iniciei tal processo de análise na realização dos diários de campo, no qual foram anotadas as impressões iniciais que tinha enquanto realizava a pesquisa e sugeria possíveis interpretações para tais impressões. No processo surgiam ainda questões a serem mais cuidadosamente observadas e analisadas. Foi durante o processo que se destacou a forma como Vinícius mediava a relação dos discentes com o conteúdo, e que esta poderia proporcionar possibilidades de emancipação aos estudantes. 
Durante e após essa etapa, realizei repetidas leituras dos documentos que orientam e compõem a prática de Vinícius, bem como o diário de campo, permitindo intuições e hipóteses iniciais.

Então procedi a decomposição de todo o material fruto do processo de pesquisa, destrinchei-o, identifiquei características, procedi a uma primeira classificação. Nesta etapa elegi eixos de análise em relação aos quais destaquei os aspectos que julguei pertinentes. Tais eixos foram o Centro Paula Souza, a Etec campo desta pesquisa, os aspectos da vida de Vinícius e sua constituição como professor, os materiais que orientam a prática de Vinícius, as mediações realizadas por Vinícius em sala de aula e os conteúdos abordados.

Este é o momento da análise que considera os fenômenos em suas especificidades per se, no qual segundo Oliveira (2005) a lógica formal contribui muito, etapa necessária do processo que revelou os aspectos importantes de cada eixo. Porém, é insuficiente, pois não revela as relações entre os eixos, não permitindo conhecer a concretude do fenômeno. No processo de realização dessa etapa, e após concluí-la, tornaram-se claras as relações entre os aspectos previamente destacados em cada eixo e o movimento da realidade estudada, ao mesmo tempo que emergiram as categorias de análise e suas formas de expressão. Será o resultado deste último movimento de análise que apresentarei sobre o que pode ser conhecido e discutido a partir da pesquisa.

Para finalizar, o processo de pesquisa aqui proposto poderia ser assim sintetizado: pelo conjunto de procedimentos elencados, busquei compreender e discutir as contribuições que traz o ensino de psicologia no contexto de uma determinada escola técnica estadual de São Paulo identificando, no contínuo movimento empírico-abstrações teóricas-concreto, uma realidade particular em sua expressão singular. Essa singularidade expressou possíveis contribuições do ensino de psicologia na formação técnica, avançando da singularidade do processo estudado, por meio de mais abstrações e análises, em direção à sua universalidade, ao buscar o conhecimento geral de suas bases e possibilidades, bem como sugerir possíveis caminhos de resistência e transformação.

\subsection{Caracterização do campo desta pesquisa}

\subsubsection{A Etec}


Apresento aqui a caracterização da Etec campo desta pesquisa, a partir das informações obtidas no processo de trabalho de campo e das informações disponibilizadas em seu site. Ainda que tenha obtido consentimento quanto à identificação do nome da instituição optei por não fazê-lo, a fim de proteger o sigilo de Vinícius.

A Etec campo existe desde a década de 60. Nasceu do desmembramento de outra Etec, ficando responsável pelo setor de Mecânica Industrial. Na época era constituída de um público discente essencialmente masculino. Como ocorreu com as escolas técnicas estaduais existentes, passou pelas diversas reformas discutidas no capítulo sobre educação profissional técnica no Brasil e no estado de São Paulo.

A sede da Etec campo desta pesquisa localiza-se na zona leste da cidade de São Paulo. Possui ainda extensões em outras localidades, as quais oferecem cursos técnicos presenciais e atendem aproximadamente 250 discentes.

Deter-me-ei em caracterizar apenas a escola sede, pois foi o campo no qual desenvolvi a pesquisa.

A escola fica próxima a estações de metrô, um teatro e alguns shoppings, numa região que concentra empresas de comércio e prestação de serviços.

De segunda a sexta-feira a escola funciona em três turnos, sendo o período da manhã reservado ao ensino médio propedêutico e os períodos da tarde e noite aos cursos técnicos de Automação Industrial, Manutenção Automotiva, Mecatrônica, Mecânica, Marketing e Administração. Oferece ainda, aos sábados, no período da manhã, cursos semipresenciais de "Administração de Empresas", "Gestão de Pequenas Empresas" e "Secretariado e Assessoria". Eventualmente são oferecidas turmas do Programa Estadual de Qualificação Profissional (PEQ), cursos breves, apostilados e direcionados a trabalhadores desempregados. Em relação aos cursos semipresenciais e ao PEQ, pelo que foi observado, os mesmos pouco se integram à dinâmica da escola, tendo materiais pedagógicos e controle administrativo próprio, assim, não serão abordados no escopo da pesquisa.

Os cursos técnicos de Administração e Marketing são relativamente recentes na história dessa Etec, sendo que o primeiro passou a ser oferecido em 2003 e o segundo em 2009. Não foi possível verificar desde quando o curso técnico de Administração é oferecido no âmbito das Etecs, mas pelo menos desde 1998. Quanto ao curso de técnico em Marketing, é recente também na história das Etecs. A partir do segundo semestre de 2007 passou a ser oferecido o curso de técnico em 
Marketing e Vendas, o qual parou de ser oferecido no segundo semestre de 2009. O curso de Marketing, propriamente, começou a ser oferecido no primeiro semestre de 2009 (informações obtidas no site www.cpscetec.com.br/bdcetec/index.php).

Em relação aos cursos técnicos no período da tarde (que foram os observados), cada aula tem duração de uma hora, e os discentes tem quatro aulas por dia - em geral as disciplinas são ministradas em duas aulas consecutivas.

O corpo docente é contratado pelo regime da Consolidação das Leis do Trabalho e é formado por 80 professores, sendo 57 licenciados (71,3\%), 20 bacharéis $(25,0 \%)$ e 3 com curso técnico $(3,7 \%)$. Os docentes com prioridade de escolhas das aulas são os licenciados, seguidos dos com formação em nível superior. Há incentivo para que docentes sem licenciatura a cursem, pois cada vez mais esta é uma exigência dentro do Centro Paula Souza.

As reuniões de docentes ocorrem no período de planejamento anterior ao início de cada semestre e duas vezes a cada semestre, aos sábados. No entanto, como grande parte do corpo docente dá aula em mais de uma escola, é difícil fazer com que todos estejam presentes nas reuniões. Aqueles que não podem comparecer realizam virtualmente a leitura e a apreciação pessoal do material a ser discutido. Para cada hora-aula os docentes recebem $20 \%$ de hora-atividade para desenvolvimento de atividades afins ao exercício docente, porém, além das reuniões elencadas acima, não são realizadas com o coletivo da escola. Essa fragmentação resulta no pouco diálogo e no desencontro de informações sobre projetos e acontecimentos na escola, especialmente em relação aos docentes que a frequentam poucas vezes por semana, como no caso de Vinícius. Tal fragmentação dificulta ainda a produção de um coletivo que possa resistir às condições de trabalho fundadas em hierarquia e autoritarismo presente nas Etecs, desvendadas no próximo capítulo.

Quanto à estrutura física da escola, é ampla, possui um jardim bem cuidado e áreas de convivência (pátio coberto, mesas e cadeiras numa área aberta). Possui dois prédios distintos. Em um deles estão os laboratórios, sendo um de biologia, física e química e outros da área da indústria: AutoCAD, mecânica, automobilística, robótica, comando numérico computadorizado, eletroidráulica, eletropneumática, metrologia, ensaios (tração e embutimento), metalografia, eletromecânica e eletrotécnica. Ao lado deste prédio, há uma quadra de esportes descoberta. 
O outro prédio possui dois andares. No térreo funciona a parte administrativa, a biblioteca com computadores para uso dos discentes, o refeitório dos discentes (que tem um micro-ondas para que os discentes possam esquentar suas refeições), o pátio coberto e a cantina da escola. O pátio dá acesso ainda aos quatro laboratórios de informática, ao laboratório de gestão, aos banheiros e ao auditório, ao lado do xerox da escola. No primeiro andar há 14 salas de aulas (todas equipadas com televisão - e a escola possui ainda projetores e potentes caixas de som), sala de coordenação de área, sala dos professores, banheiros e permite acesso à sala de capacitação. A maioria das salas fica num lado, e há um corredor no qual fica uma mesa para os dois inspetores de discentes e armários que são alugados aos discentes, especialmente aos que fazem ensino médio e técnico na mesma escola. Ao lado deste prédio há ainda uma quadra coberta e o estacionamento.

O espaço físico da escola está sempre bem cuidado, limpo e livre de pichações.

A Etec conta com 17 funcionários administrativos, um auxiliar docente, quatro estagiários contratados pela FUNDAP ${ }^{45}$, além de serviços terceirizados de vigilância e limpeza. Além de uma diretora e uma coordenadora da escola, há coordenadores de área do Ensino Médio e de cada um dos cursos técnicos oferecidos.

Seja pela estrutura física ou pela equipe de apoio, os recursos da escola impressionam quando comparada a uma escola de mesmo porte da rede estadual de ensino médio propedêutico, em geral com muito menos recursos.

Quanto à proposta pedagógica da Etec, no item do Plano Plurianual de Gestão da Etec que versa sobre o Projeto Político Pedagógico, os princípios que norteiam o trabalho ensino-aprendizagem são "Formar o aluno capaz de aprender a aprender e prepará-lo para o mundo profissional pautado nos valores de respeito, solidariedade, responsabilidade e no desenvolvimento de características como empreendedorismo e liderança". Como dito anteriormente, tais princípios são os mesmos tanto para a modalidade propedêutica quanto para a técnica, e entendo que enfatizam o ser em suas características subjetivas individuais propagadas como valorizadas no mercado de trabalho e abstêm-se em relação à socialização dos conhecimentos histórico-socialmente construídos e a análise crítica dos mesmos e da sociedade.

45 Fundação do Desenvolvimento Administrativo (FUNDAP). 


\subsubsection{Os discentes}

Um perfil preliminar dos discentes é encontrado no Plano Plurianual da Etec. Esse perfil é construído com base nas impressões dos componentes da escola quanto ao corpo discente; conhecimento legítimo, mas pouco preciso, dado que a escola não mantém registros organizados de informações que poderiam trazer outras nuances às suas primeiras impressões. No documento consta que os discentes em sua maioria não moram no bairro, sendo oriundos de bairros vizinhos ou mesmo de cidades da região metropolitana da São Paulo. Têm entre 15 e 25 anos. Provêm de escolas públicas, no caso dos cursos técnicos, e escolas particulares e públicas no caso do ensino médio propedêutico. Os discentes do período diurno não trabalham enquanto os do período noturno sim, e ambos viriam em busca de um ensino de qualidade, pois a escola teria nome e tradição tanto em relação ao ensino médio quanto ao técnico, além de bom desempenho no ENEM.

Considerei importante ter mais detalhes sobre o perfil dos discentes que frequentam a escola, e, conforme explicitado no item 3.4.2, realizei levantamento com tal fim.

Com base nesse levantamento obtive que a escola atendia ao final do segundo semestre de 2010 a 1.552 discentes na sede, sendo 1.083 no ensino técnico $(69,8 \%)$ e 469 no ensino médio propedêutico $(30,2 \%)$.

O público de discentes na escola sede é constituído de $70,4 \%$ de estudantes do sexo masculino, talvez pela característica da história da Etec e dos cursos oferecidos, a maioria da área da indústria, nos quais as vagas de trabalho foram tradicionalmente ocupadas por este gênero. No entanto permanece uma predominância do sexo masculino também no Ensino Médio propedêutico - 64,2\% -, o que diverge da distribuição por sexo em âmbito nacional no ensino médio propedêutico, no qual a população masculina representa 45,1\% (BRASIL, 2009c). Nos cursos técnicos de Administração e Marketing, a distribuição é mais igualitária, sendo a população masculina correspondente a $42,4 \%$ e $45,75 \%$ respectivamente, o que é mais próximo da distribuição por sexo no ensino médio profissional, na qual o público masculino corresponde a 47,5\% (BRASIL, 2009c).

Quanto ao perfil dos discentes em relação à faixa etária, o gráfico a seguir mostra tal distribuição, distinguindo entre ensino médio propedêutico, ensino técnico no período da tarde e ensino técnico no período da noite. 
Gráfico 2 - Perfil dos discentes da Etec campo desta pesquisa quanto a distribuição por faixa etária.

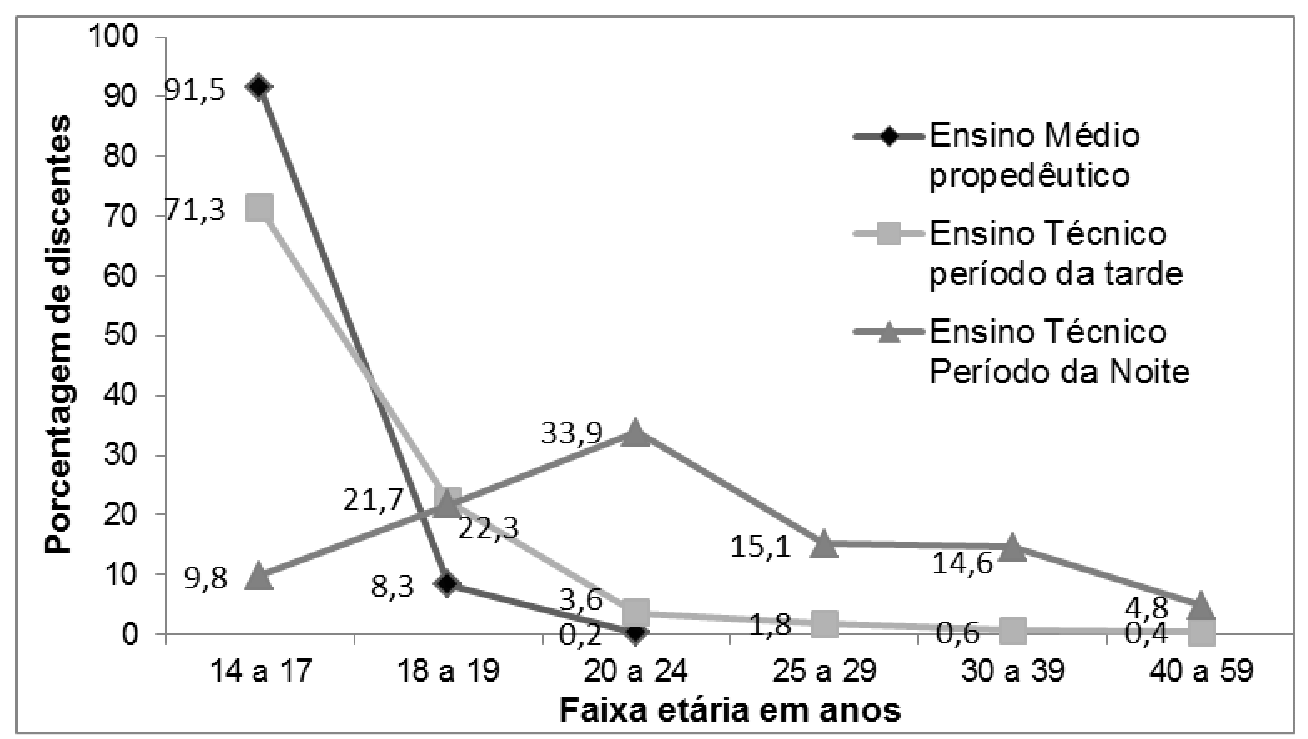

Pelo gráfico pode-se observar que enquanto no ensino médio propedêutico há uma concentração de discentes na idade escolar própria e este nível de ensino $91,5 \%$ com idade entre 14 e 17 anos -, esta concentração se torna menos acentuada no ensino técnico no período da tarde, que tem $71,3 \%$ dos discentes com idade entre 14 e 17 anos e $22,3 \%$ de 18 e 19 anos, o que seria esperado, visto que tais cursos são concomitantes ou subsequentes e apenas podem ser cursados por discentes que tenham concluído ao menos a primeira série do ensino médio propedêutico. No ensino técnico no período da noite, há uma distribuição difusa entre as faixas etárias, abrangendo dos 14 aos 59 anos, com a maior parte dos discentes com idade entre 20 e 24 anos (33,9\%), constituindo assim um perfil mais heterogêneo no que se refere à faixa etária e sugerindo que a maioria dos discentes do período noturno cursa o ensino técnico de forma subsequente.

Essa hipótese se fortalece ao analisarmos os dados dos cursos técnicos de Administração e Marketing quanto à situação do Ensino Médio propedêutico.

Pelo Gráfico 3 pode-se observar que no período da tarde a maior concentração é de discentes cursando o Ensino Médio propedêutico e que no período da noite a situação se inverte, sendo maior a concentração de discentes que possuem o Ensino Médio propedêutico concluído. 
Gráfico 3 - Perfil dos discentes dos cursos técnicos de Administração e Marketing da Etec campo desta pesquisa quanto a situação do Ensino Médio propedêutico.

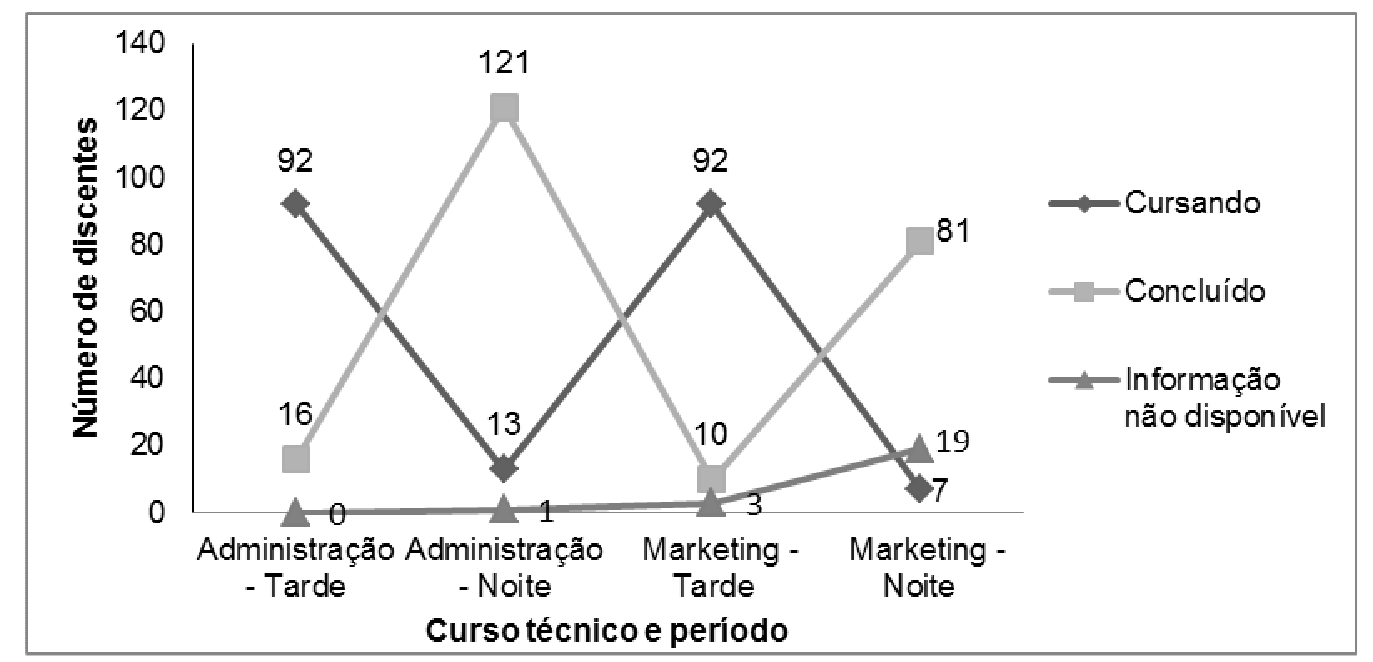

Gráfico 4 - Perfil dos discentes dos cursos técnicos de Administração e Marketing da Etec campo desta pesquisa quanto ao tipo de escola na qual cursam ou cursaram o Ensino Médio propedêutico.

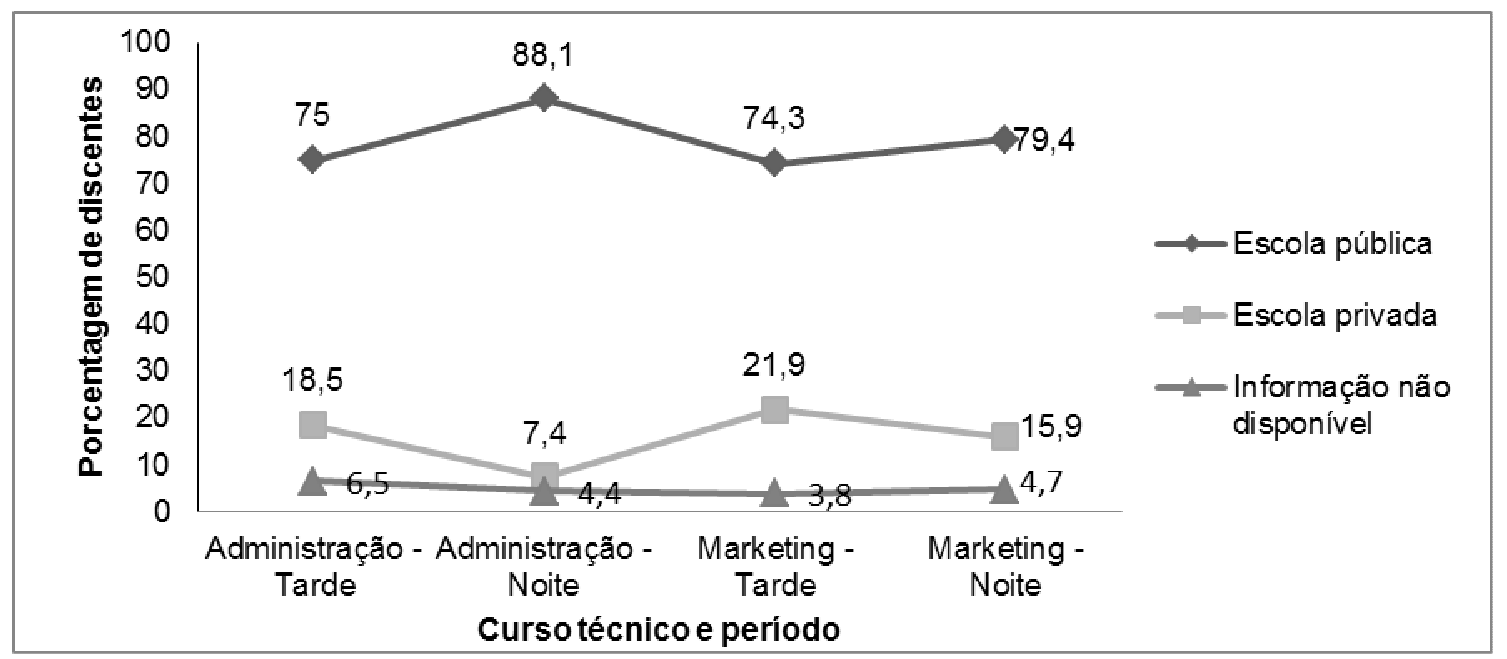

Quanto ao tipo de escola em que discentes cursam ou cursaram o ensino médio propedêutico, pelo Gráfico 4 pontuo que a maioria significativa dos discentes cursa ou cursou o ensino médio propedêutico em escola pública, ainda que haja uma percentagem variando entre $7 \%$ e $22 \%$ de discentes cujo ensino médio propedêutico é ou foi realizado em escolas privadas. Entendo que tais informações problematizam as afirmações de que as escolas técnicas públicas atenderiam a uma classe privilegiada, conforme já havia sido pontuado no capítulo sobre educação profissional. No entanto faltam informações que permitam refletir tais dados frente ao perfil de discentes do ensino médio propedêutico nas Etecs, bem como se o não 
oferecimento de ensino médio integrado seria um fator determinante quanto ao tipo de instituição da qual os discentes procederiam.

Gráfico 5 - Perfil dos discentes dos cursos técnicos de Administração e Marketing da Etec campo desta pesquisa quanto ao tipo de escola pública na qual cursam ou cursaram o Ensino Médio propedêutico.

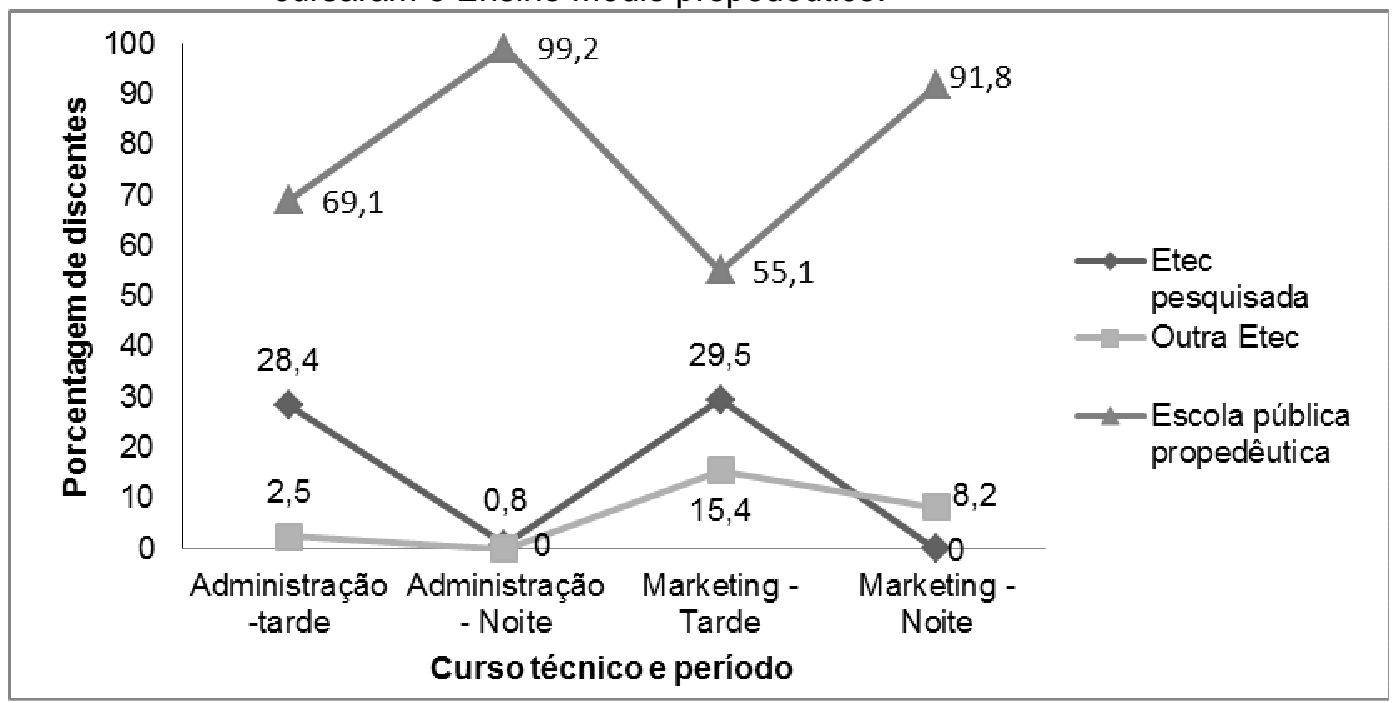

Em relação aos que cursam ou cursaram o ensino médio propedêutico em escola pública, o Gráfico 5 ilustra que a maioria dos discentes o fazem ou fizeram na rede de ensino propedêutica. Quanto aos que o fazem na rede de ensino técnica, pela pesquisa observei que todos estão cursando o ensino médio propedêutico concomitantemente ao ensino técnico. Noto ainda que, no curso de técnico em Marketing no período da tarde, $15,4 \%$ cursam o ensino médio propedêutico em outra Etec e que no período da tarde há uma incidência de $28 \%$ a $29 \%$ de discentes que cursam o ensino médio propedêutico na Etec campo desta pesquisa. Ainda que no âmbito da Etec não haja possibilidade de ensino médio integrado, cursar concomitante o ensino médio propedêutico e o ensino técnico na escola campo desta pesquisa ou em outra Etec poderia possibilitar certa unidade de proposta pedagógica a partir do Centro Paula Souza. No caso dos que cursam o ensino médio propedêutico e o ensino técnico na mesma Etec, tal unidade pedagógica é explicitada no Plano Plurianual de Gestão da Etec, no qual o Projeto Político Pedagógico é essencialmente o mesmo seja para a modalidade propedêutica ou técnica, reservando apenas alguns destaques de especificidades para alguns dos cursos técnicos. 
Ainda em relação aos discentes, durante o processo de pesquisa de campo observei que discentes tinham das mais diversas intenções quanto ao futuro, não necessariamente vinculadas ao curso técnico cursado, por vezes ficando para mim a impressão de que o curso era mais uma atividade complementar, extracurricular, do que propriamente de formação profissional. Assim havia a discente que deseja ser chefe de gastronomia, outra engenheira naval, o discente que quer ser historiador, outro jornalista, outro quer abrir seu próprio negócio, dois que querem cursar o ensino superior de Marketing (uma inclusive que o cursava concomitantemente ao curso técnico). O que nos coloca diante de um perfil bastante diferenciado de discente, e pouco conhecido, que precisaria também ser estudado com maior profundidade.

\subsubsection{O docente}

Vinícius tem em torno de 45 anos de idade e graduou-se no início dos anos noventa na licenciatura em Psicologia e Formação de Psicólogo pela Pontifícia Universidade Católica (PUC). Conta que o cursar a licenciatura e tornar-se docente não foi fruto de uma escolha refletida: "não sei como surgiu isso de ser professor".

Profissionalmente Vinícius já atuou como psicólogo clínico e psicólogo organizacional, fez aprimoramento em psicologia hospitalar e foi professor de Psicologia no ensino médio propedêutico. É professor em Etecs desde o ano 2000 e aos poucos a profissão de docente assumiu exclusividade em sua vida profissional. Atualmente é docente em três Etecs, sendo que em uma destas é coordenador de área. Ministra aulas também para o curso técnico de Enfermagem em uma instituição privada de ensino. Tem uma carga horária de trabalho de aproximadamente 40 horas semanais.

Vinícius explicita sua opção teórica pela psicanálise, porém, na atividade docente, como é requerido, ministra conteúdos a partir de diversas teorias e autores.

Diferentemente do que apontam os textos sobre práticas dos docentes de psicologia no ensino técnico de enfermagem (PIRES, 2009) e médio propedêutico (MERCH, 2001, 2007) e consoante ao que aponta Dadico (2009), Vinícius demonstra clareza de que o seu papel em sala de aula é de educador, e não psicólogo. Isso fica claro em suas falas, como: "nenhum momento eu procurei atuar como psicólogo porque eu sei que não é nosso papel, o nosso papel é a 
aprendizagem, então eu sempre deixei claro que aqui eu não estou fazendo terapia com ninguém", e também em sua conduta em sala de aula, como pude observar durante o processo de pesquisa.

Vinícius manifesta gostar bastante de dar aula, e essa paixão transparece em suas aulas no relacionamento com os discentes. No processo de pesquisa foi sempre solícito, acolhendo-me em suas salas de aula, comentando questões pertinentes durante os momentos de intervalo e esclarecendo minhas dúvidas. Ainda que a existência de alguém estranho à dinâmica da aula por vezes o inquietasse - $e$ ele expressasse isto (conforme anteriormente relatado) -, Vinícius foi extremamente generoso comigo, desde o permitir minha entrada em campo e durante todo 0 processo de pesquisa, o que entendo como uma postura de coragem e abertura a fim de contribuir para a minha formação e para o processo de produção do conhecimento. 


\section{PROCESSOS POTENCIALMENTE ALIENANTES E EMANCIPATÓRIOS: EXPRESSÕES E CONTRIBUIÇÕES DO ENSINO DE PSICOLOGIA NAS ETECS}

\subsection{Esclarecimentos preliminares}

À medida que avançava na compreensão dos dados da pesquisa e nas leituras teóricas, fui fortalecendo a convicção de que as categorias de análise diriam respeito a processos potencialmente alienantes e processos potencialmente emancipatórios no ensino de psicologia das Etecs.

Porém, ao separar os primeiros dos segundos, assumi o risco de dicotomizar a realidade, e, para minimizá-lo, dois cuidados foram tomados: 1) explicitei a relação entre as categorias; 2) não excluí da análise as contradições, assim, o leitor em alguns momentos perceberá que há indícios de emancipação mesmo nos processos considerados como potencialmente alienantes e indícios de alienação nos processos considerados como potencialmente emancipatórios.

O segundo cuidado revela ainda que, em uma realidade contraditória, mesmo um processo considerado como alienante pode produzir em alguns indivíduos possibilidades de emancipação, sendo o contrário também verdadeiro. $O$ uso do termo potencialmente na denominação das categorias visa explicitar tal compreensão, na qual se identifica uma tendência em direção $a$, porém não se pressupõe que esta inevitavelmente se concretizará da forma como primeiramente identificado.

$\mathrm{Na}$ definição dos processos potencialmente alienantes, parti da maneira pela qual Marx (2008) compreende alienação ${ }^{46}$ como algo que se impõe a todos na nossa sociedade e que se expressaria no:

46 Segundo Ranieri (2008) há, na obra de Marx, uma distinção entre os termos Entäusserung e Entfremdung, os quais significariam alienação e estranhamento, respectivamente. Nas apropriações feitas de tais termos e nas primeiras traduções das obras de Marx para o português, os termos foram tomados como sinônimos e traduzidos como alienação, uma vez que no capitalismo ambos estariam identificados com as formas de apropriação do excedente de trabalho e da consequente desigualdade social, adotando-se alienação como categoria universal que serviria à crítica do sistema capitalista. $O$ autor não considera que Marx tenha utilizado os termos como sinônimos e por isso os distingue. Porém, ainda que eu utilize sua tradução dos Manifestos econômico-filosóficos, neste trabalho utilizarei os dois termos seguindo a denominação que consta nas obras referenciadas, mas os considerarei como sinônimos, pois no meu entendimento os demais autores utilizados o fizeram. 
1. Estranhamento do homem em relação a natureza que compreende o meio a partir do qual (no sentido de recursos de subsistência) e por meio do qual (no sentido da produção de objetos) o trabalho se efetiva. Tanto os meios de subsistência quanto os produtos do trabalho humano são negados ao trabalhador, que não os possui e deles depende, tornando tais objetos estranhos e poderosos diante dele.

2. Estranhamento do homem diante de si mesmo no ato da produção. Ao não possuir o mundo objetivo que produz, tão menos o trabalhador possui a si próprio e menos poder tem sobre suas atividades.

3. Estranhamento do homem em relação ao gênero humano. $O$ homem se relaciona com o gênero quando se apropria das objetivações que outros homens produziram ao longo da história. No trabalho estranhado está impedido de se apropriar de suas produções e assim, consequentemente, impedido de se relacionar com o gênero. $O$ trabalho aparece apenas como meio para satisfação da carência de manutenção da vida física. Sua dimensão de forma de relacionamento com a vida genérica é extirpada.

4. Estranhamento do homem pelo próprio homem. Na relação do trabalho estranhado, cada homem considera o outro segundo a forma como ele mesmo se encontra como trabalhador, como meio de produção que está estranhado em relação a todas as formas acima e, assim, estranhado de sua natureza humana social e histórica.

Considerei ainda que a alienação, produzida pela divisão social do trabalho e pela propriedade privada, se faz presente em todos os âmbitos da vida. No que se refere à consciência, a alienação pode ser percebida no estranhamento produzido entre significado e sentido pessoal das atividades humanas, conforme pontua Leontiev (1978).

Assim, conforme sinalizado na introdução, o significado seria compartilhado socialmente e seria referente às finalidades humanas próprias de cada atividade; já o sentido seria pessoal, construído a partir das condições objetivas de vida e dependente do motivo que o impulsiona para esta atividade. No caso da educação, a partir do Materialismo Histórico-Dialético, seu significado social seria humanizar os indivíduos a partir da apropriação crítica dos conhecimentos histórico-socialmente construídos, objetivada para a melhoria da qualidade de vida para todos. No entanto, 
os sentidos que a escola assume para a sociedade, para docentes e discentes, pode ser bem diverso, estando para as Etecs muitas vezes subordinados à preparação da mão de obra o mais adequada possível às demandas ideológicas do capital - em especial no que diz respeito à produção de uma subjetividade disciplinada, que internalize a responsabilidade individual de se adequar à instabilidade e fluidez dos processos produtivos. Para os discentes fica o papel de vantagem individual na concorrência por um emprego. A educação enquanto apropriação e objetivação da vida genérica é estranhada, estando vinculada unicamente ao sentido que tem para a sociedade capitalista, o que vai sendo imposto por diversos mecanismos que apresentarei nas condições de trabalho.

Considerando que a restauração da posse do produto e do processo de trabalho não são realizáveis na sociedade em que vivemos e a partir desta compreensão teórica sobre alienação, entendi como processos potencialmente alienantes aqueles nos quais o ensino de psicologia: dificultou a posse dos conhecimentos histórico-socialmente construídos, aprofundando o estranhamento na relação com o gênero; dificultou o estabelecimento de relações do homem com outros homens e consigo mesmo enquanto seres histórico-sociais; subordinou os conhecimentos psicológicos aos interesses do capital, aprofundando a dissociação entre significado e sentido. A partir do processo de pesquisa de campo e dessas compreensões, considerei que o ensino de psicologia contribui para processos potencialmente alienantes: 1) na redução do conteúdo a seu uso instrumental; 2) na marginalidade dos conteúdos; 3) na ênfase em prescrições de formas de ser e agir; e 4) nos equívocos no ensino de conteúdos.

Para a definição dos processos potencialmente emancipatórios, considerei aqueles que apontavam para a ruptura da alienação, ainda que tenha clareza que a emancipação não se restringe a essa dimensão, pois segundo Duarte (2004, p. 47) a emancipação requer não só a ruptura, mas a superação dos processos sociais alienados e envolve ainda a diferenciação dos processos naturais e espontâneos, distanciando-se da relação inicialmente imediata com a natureza, podendo dedicarse cada vez mais a questões não relacionadas estritamente a sua subsistência física.

Para Tonet (2005) a emancipação só se efetivaria no conjunto dos homens quando todos pudessem desfrutá-la em igualdade de condições. Porém, na sociedade dividida em classes, uma aproximação a emancipação pode ser mais 
possível para aqueles a quem o acesso a produções materiais e culturais exista. De acordo com o autor (TONET, 2007), o que é possível fazer na atualidade no âmbito da educação são atividades que apontem no sentido da emancipação.

Assim, compreendo que a emancipação no âmbito da educação implicaria na produção de rupturas em algumas dimensões do estranhamento. Como já expus, a superação do estranhamento em relação ao produto e ao processo de trabalho não seria realizável nesta sociedade. Quanto a essas dimensões o que é possível é saber-se estranhado e desvendar os mecanismos que determinam sua impossibilidade de apropriar-se do produto e do processo de trabalho, ou seja, desnaturalizar estes processos, reconhecê-los como sociais e produzidos pelos próprios homens.

Em relação à dimensão do estranhamento do gênero humano, se o homem não pode se apropriar das objetivações genéricas humanas no trabalho - e para a maior parcela da população também na vida -, a escola pode ao menos possibilitar que os indivíduos se apropriem de algumas das objetivações humanas: os conhecimentos histórico-socialmente construídos, restituindo assim uma parcela da relação do indivíduo com o gênero humano.

Esse papel da educação tem sido defendido por teóricos da Pedagogia Histórico-Crítica e da Psicologia Histórico-Cultural, para os quais a apropriação dos conhecimentos histórico-socialmente construídos é papel fundamental da educação. Conforme nos lembra Saviani (2000), apropriar-se dos conhecimentos não é suficiente, pois os mesmos precisariam ser historicizados, resgatados em sua objetividade, universalidade e movimento contraditório, e não tomados em sua pretensa autonomia e neutralidade. Para Tonet (2007) seria preciso ainda que os conhecimentos ensinados tivessem em seu horizonte "uma ordem social qualitativamente diferente" (p. 71).

A partir da compreensão sobre alienação e emancipação, considero que outra possível contribuição da educação na produção de fissuras em dimensões do estranhamento seria proporcionar que o indivíduo pudesse se identificar com outro homem em suas condições humanas, e não como meio de produção.

Pela pesquisa de campo foi possível identificar o ensino de psicologia como contribuindo: para a restituição, ainda que parcial, da posse sobre os conhecimentos histórico-socialmente construídos, restituindo parte da relação com o gênero; e também para o resgate da relação com o outro homem e consigo mesmo enquanto 
ser histórico-social. Como apresentarei a seguir, as expressões de processos potencialmente emancipatórios encontradas na prática estudada são incipientes, distantes do que apresentei aqui como emancipação - até porque na sociedade alienada que vivemos, condicionada por interesses que se opõem a emancipação humana, qualquer ensino tem limites para proporcioná-la. Mas são faíscas, produziram fissuras e envolveram: 1) relações de respeito mútuo; e 2) ensino de conhecimentos histórico-socialmente construídos.

Cabe lembrar que as expressões do ensino de psicologia destacadas como contribuindo para processos potencialmente alienantes e emancipatórios não são consideradas como práticas individuais de Vinícius e processos presentes apenas nas aulas observadas, mas compreendidos como expressões universais do ensino de psicologia quando situados frente aos condicionantes desvendados. Como o ensino se concretiza na sala de aula, na prática de Vinícius em sua relação com os discentes, na qual seu papel de mediador é fundamental, os exemplos predominantemente se centraram nele, mas foram compreendidos a partir de suas condições de trabalho, que como veremos são limitadoras e alienantes, ainda que existam brechas para práticas diferentes.

Por fim, tendo em vista os diversos fatores que incidem sobre o trabalho dos docentes nas Etecs, considerei importante apresentar uma prévia destes, a fim de que o leitor compreenda um pouco o contexto pelo qual as expressões do ensino de psicologia nas Etecs estão condicionadas. Porém, ainda que o ensino de psicologia apresentado a seguir expresse (dimensão passiva) seus múltiplos condicionantes, é preciso ter clareza que ele não faz só isso, mas contribui (dimensão ativa) ou para o aprofundamento ou para a ruptura de processos alienantes.

A seguir, primeiramente apresento as condições de trabalho comuns aos docentes nas Etecs e posteriormente apresento condições que são específicas a cada uma das disciplinas observadas.

\subsection{Condições de trabalho}

Por um lado as condições de trabalho nas Etecs poderiam ser consideradas como privilegiadas se comparadas à rede estadual de escolas propedêuticas por, como visto na caracterização da escola, usufruir de uma estrutura física e recursos diferenciados e também, na atualidade, gozar de certa valorização da opinião 
pública - são as escolas técnicas públicas que têm melhores resultados no ENEM e sobre as quais há uma propaganda de garantia de empregabilidade para quem as cursa -, com um ambiente, ao menos na Etec campo desta pesquisa, em que não presenciei ocorrência de ruídos que viessem a dificultar o andamento das aulas, nem de agressões verbais ou físicas e na qual discentes eram respeitosos com docentes e participantes das aulas. Essas condições fazem com que os docentes expressem que ali "estão no céu", referindo-se especialmente aos discentes, que são tidos como possuidores de um repertório acadêmico mais refinado e também por serem respeitosos, questões relacionadas, segundo os docentes, a existência do processo seletivo para ingresso na escola. Esse perfil dos discentes gera ainda uma expectativa e investimento em relação aos mesmos, não só de que ingressem no mercado de trabalho e ascendam socialmente, mas de que cursem o ensino superior.

Considerando tais condições de trabalho, muitos dos fatores relacionados ao esgotamento docente, ou burnout, apontados por Barros (2009) e pelas pesquisas que por ele citadas, não foram identificados.

No entanto outros fatores - como o cerceamento da autonomia, preparo inadequado, baixa remuneração, falta de coletividade - estão presentes nas condições de trabalho nas Etecs. E, como também aponta Barros (2009), impõem sofrimento, condicionam aos poucos que docentes se rendam a condições de trabalho impostas e façam o necessário para que sua sobrevivência seja garantida.

llustrarei como tais questões se impõem na realidade das Etecs para então explicitar que limitações e consequências trazem para o trabalho dos docentes. Quando discutir as expressões e contribuições do ensino de psicologia neste campo, me remeterei a essas condições para o compreendermos.

Um primeiro aspecto que impõe limites ao trabalho nas Etecs é a naturalização com que se propaga e se aceita que a finalidade nas mesmas não é a formação humana crítica, mas somente formar profissionais adaptados ao mercado de trabalho. Isso pode ser inferido tanto pelas propagandas em relação a Etecs quanto ao fato das mesmas serem vinculadas à Secretaria de Desenvolvimento, como vimos no capítulo sobre educação profissional.

Nesse sentido parece-me bem apropriada, também quando se reflete sobre a educação profissional, a afirmação de Adorno (1995a, p. 143) de que 
A educação seria impotente e ideológica se ignorasse o objetivo de adaptação e não preparasse os homens para se orientarem no mundo. Porém, ela seria igualmente questionável se ficasse nisto, produzindo nada além de well ajusted people, pessoas bem ajustadas, em consequência do que a situação existente se impõe precisamente no que tem de pior.

No entanto, no campo das Etecs naturaliza-se o abandono da formação crítica, e a adaptação é imposta de diversas formas que condicionam o trabalho dos docentes. Uma delas é a elaboração centralizada tanto das matrizes curriculares que prevê disciplinas, suas cargas horárias e o módulo em que serão oferecidas quanto dos Planos de Curso, que conforme apresentarei abaixo não figuram como referências passíveis de discussões e reformulações, mas como imposições que devem ser simplesmente obedecidas.

Assim, para cada um dos cursos oferecidos há um Plano de Curso, formulado por uma equipe técnica do Centro Paula Souza com a participação de profissionais da área, docentes especialistas e supervisão educacional, nos quais se expressa como finalidade "a construção de um currículo mais afinado com o mercado de trabalho". Os docentes das Etecs não participam da construção dos Planos de Curso e não têm canais institucionais para debatê-los e poder modificá-los. Os Planos de Curso são os mesmos, independente da Etec nas quais um dado curso é ministrado. Neles consta a descrição da profissão e do perfil de profissionais que se quer formar, um rol de atividades que os discentes deverão saber realizar ao concluírem cada módulo e o curso e as "competências, habilidades e bases tecnológicas" que o curso deverá garantir que os discentes dominem em cada disciplina, em cada módulo e no curso como um todo. Embora o processo pedagógico se baseie nas competências e posteriormente nas habilidades, não há definição desses termos e ações ou características que ora aparecem como competência em seguida aparecem como habilidade. Já as bases tecnológicas estariam relacionadas aos conteúdos teóricos necessários ao desenvolvimento das competências e habilidades elencadas. Tais bases tecnológicas aparecem na forma de temas a serem desenvolvidos nas aulas. Como vimos no capítulo sobre educação profissional, essa ênfase nas competências e a organização dos cursos por módulos, entre outras questões, exacerba a valorização de características individuais do trabalhador em detrimento de características formativas que o curso deveria prover, direcionando a uma responsabilização individual por um futuro desemprego. 
Além desta elaboração centralizada do Plano de Curso, que direciona o ensino para os fins discutidos, a situação se agrava e impõe ainda mais limites às possibilidades de autonomia docente, pois o Plano de Trabalho Docente - que seria o documento no qual estes planejariam o que seria desenvolvido durante o semestre para cada uma das disciplinas ministradas - deve ser uma cópia fiel do Plano de Curso (conforme previsto em normas e ressaltado na fala de Vinícius), imposto às Etecs. A única intervenção permitida aos docentes é o acréscimo de bases tecnológicas, desde que estejam estritamente vinculadas às competências já previstas para serem desenvolvidas na disciplina.

Ou seja, prevê-se que os docentes não tenham autonomia para decidir sobre quais temas poderão ser desenvolvidos em suas salas de aula, e há uma clara subordinação à produção de competências predominantemente relacionadas a atividades técnicas que discentes devem aprender a realizar e a formas de ser às quais discentes devem se adequar (ainda que hajam ênfases diferenciadas em relação à técnica nas diferentes disciplinas e cursos, conforme apresentarei quando falar das condições de trabalho específicas às disciplinas Psicologia Organizacional e Psicologia Social). Por tais questões compreendo que há o objetivo de reduzir os docentes a técnicos que não precisariam pensar, refletir sobre a sua própria prática, e que devem limitar-se a reproduzir o que foi planejado centralizadamente.

Há ainda mecanismos de controle que buscam garantir que o planejado pelo Centro Paula Souza foi cumprido na Etec como um todo e em cada disciplina, efetivado por um sistema em que avaliadores externos à escola verificam anualmente a correspondência entre Planos de Curso, Plano de Trabalho Docente e registros de diário de classe (no qual deve constar o tema desenvolvido a cada aula).

Outro mecanismo de controle, relacionado tanto ao predomínio da técnica quanto ao ensino de como discentes devem ser e agir, é a criação de instrumentos que permitam avaliar o índice de empregabilidade dos egressos por curso e escola. Entendo como mecanismo de controle porque o Centro Paula Souza relaciona a qualidade do ensino dos cursos técnicos na Etec ao quanto seus discentes conseguem ou não empregos, e este é um dos aspectos que influirão sobre os recursos que serão a Etec destinados. Entendo que assim se condiciona o ensino oferecido à adequação dos discentes a um perfil profissional que seria desejável no mundo produtivo, adaptável e flexível, conforme vimos no capítulo sobre educação 
profissional, e também ao que é recorrentemente divulgado nos meios de comunicação, abarcando receitas de como um candidato a emprego deve se portar numa situação de seleção e como deve agir no emprego caso contratado (como, por exemplo, as falas de Max Gehringer no programa Fantástico, da TV Globo, ou livros de autoajuda para se tornar um profissional de sucesso). Passa-se então a tomar os padrões tão exaustivamente divulgados nesses meios como comportamentos a serem produzidos nos discentes para que possam sair da Etec "empregáveis", buscando garantir assim "qualidade" que se reverta em mais recursos para a Etec e também reconhecimento social.

Porém, ainda que aqui e durante todo o texto que se seguirá eu aponte muitas questões que condicionam o trabalho dos docentes nas Etecs e a elas dê destaque, considero importante ressalvar que estas nos possibilitam compreender porque algumas questões se expressam de determinadas formas, o que não quer dizer que seja necessariamente assim que elas precisariam se expressar. Com isso quero afirmar que há brechas para a criação de possibilidades de resistência, crítica e subversão das normas, pois ao menos dentro da sala de aula docentes têm autonomia. Ainda que lhe sejam impostos temas e a função a qual os mesmos devem se subordinar - as competências -, a forma de ensiná-los não precisa aterse às funções previstas (explicito algumas destas possibilidades nas Considerações Finais).

Porém, também compreendo que a possibilidade de resistir a todos esses mecanismos é dificultada, pois, como visto na caracterização da Etec, há escassez de espaços institucionais que estimulem a constituição de um coletivo, ficando cada docente muito isolado em suas próprias práticas e submetido ao controle institucional explicitado. Além disso, não há no âmbito do Centro Paula Souza promoção de processos de formação contínua em que docentes das disciplinas que envolvem ensino de psicologia possam refletir coletivamente sobre os conteúdos ministrados e as práticas realizadas. Ao longo do tempo, submetidos a tais condições de trabalho, penso que muitos docentes acabam por resignar-se e passam a fazer o que deles é esperado, como considero, aconteceu com Vinícius.

Outro fator agravante é a carga horária de trabalho necessária para se obter remuneração que possibilite um mínimo de dignidade e a insuficiência da destinação de tempo remunerado para estudo, planejamento e correção de atividades, pois, para cada aula de duas horas, remunera-se 24 minutos para planejamento. Assim, 
docentes têm poucos momentos remunerados para pensarem suas próprias atividades e, dado o baixo valor recebido por hora-aula, têm que se submeter a uma carga horária de trabalho alta (no caso de Vinícius, aproximadamente 40 horas semanais, distribuídas em quatro locais de trabalho), o que dificulta que se dediquem a aprimorarem sua própria formação em outros momentos.

Uma condição de trabalho, agora específica da área da psicologia, que também limita as possibilidades do ensino de conhecimentos psicológicos nas Etecs é a marginalidade que a licenciatura historicamente ocupou nos cursos de formação em Psicologia (MRECH, 2001). Há ainda a escassez de discussões que se debrucem sobre a educação profissional (MACIEL, 2009; PIRES, 2009). Assim, mesmo que docentes se dedicassem a procurar pesquisas ou espaços coletivos que os auxiliassem a refletir sobre sua prática profissional e sobre que conhecimentos da psicologia seriam interessantes de serem ministrados nesse campo teriam dificuldade de encontrá-los, tendendo a ficar isolados em suas práticas, empobrecendo-as.

Considero que após anos submetidos a esse esquema autoritário e limitador da autonomia docente, aliado à falta de espaços de formação contínua e mesmo de conhecimentos que problematizem o ensino de psicologia em escolas técnicas, grande parte dos docentes vão perdendo ao longo do tempo (no caso de Vinícius, dez anos nas Etecs) as possibilidades de resistência e analise crítica de seu fazer, permanecendo apenas a necessidade de sobreviver e realizar aquilo que naquele contexto é aceito e valorizado. A própria fala de Vinícius, dizendo que no início da profissão pesquisava e preparava mais as aulas e que foi deixando de fazê-lo, indica a progressiva conformação ao que está posto. Acrescente a isso a falta de estímulos para transformar sua prática, uma vez que, naquela Etec, Vinícius é tido como um bom professor, reconhecido e valorizado pela coordenação da escola e outros docentes por fazer aquilo que dele se espera no âmbito das Etecs: a formação de profissionais que saibam se comportar em um ambiente profissional, objetivo ao qual, como apresentarei adiante, o docente se resigna, adere e incorpora em sua prática profissional.

Assim, considero que as características do trabalho do professor de psicologia nas Etecs fazem com que haja no ensino de psicologia o predomínio de processos potencialmente alienantes, ainda que existam brechas para que se façam 
presentes processos potencialmente emancipatórios, como analisarei nos itens 4.3 e 4.4 .

Tal predomínio é mais acentuado na disciplina de Psicologia Social quando comparado à disciplina de Psicologia Organizacional, o que penso se relacionar com a prática que se concretiza nessas disciplinas a partir da regulação dos Planos de Curso de técnico em Administração e em Marketing, respectivamente. Apresentarei as características específicas a cada uma destas disciplinas a seguir.

\subsubsection{Psicologia Organizacional}

O curso de técnico em Administração é composto por três módulos, e a disciplina de Psicologia Organizacional faz parte do primeiro módulo.

Como vimos anteriormente, o Plano de Curso é o documento que mais diretamente embasa cada um dos cursos nas Etecs - pois os outros documentos embasam práticas gerais e os Planos de Trabalho Docente são estritamente subordinados ao Plano de Curso. Então, para entender os condicionantes que intervêm nas expressões do ensino de conhecimentos psicológicos na disciplina de Psicologia Organizacional, é preciso situá-la frente ao que está previsto para ser desenvolvido no curso de técnico em Administração e para essa disciplina. Também brevemente adiantarei os temas desenvolvidos na disciplina e o relacionamento entre Vinícius e discentes na mesma, a fim de prover uma contextualização para as questões que serão analisadas nos processos potencialmente alienantes e emancipatórios.

Em uma apreciação geral do Plano de Curso de técnico em Administração, é possível identificar em algumas das bases tecnológicas a presença de uma contextualização histórica das questões a serem abordadas - "história da administração e revolução industrial" e "histórico da gestão de pessoas" - a partir da qual é possível contribuir para que discentes não apreendam de maneira naturalizada a forma hegemônica como essas questões se apresentam nos dias atuais, mas as compreendam historicamente, não havendo assim uma subordinação direta à aplicabilidade dos conteúdos.

Há neste documento uma indicação extensa e diversificada de bibliografia aos docentes do curso. Ainda que não se contemple nenhum autor fundador de teorias na área (como Freud, Skinner e Maslow, ainda que citados nas aulas), estão 
inclusos temas relacionados à psicologia - como livros de Psicologia aplicada à administração, gestão de pessoas, administração de recursos humanos e sobre as dimensões do indivíduo esquecidas na organização - os quais, como podemos ver, já são vinculados a aplicabilidade da psicologia, ainda que a ela não se restrinjam.

Quanto à especificidade da disciplina de Psicologia Organizacional, identifico, a partir das competências e das bases tecnológicas previstas no Plano de Curso, que se inicia por uma abordagem mais geral da Psicologia, a partir de teorizações sobre o indivíduo, como "ser humano: um ser multideterminado bio-psico e social", "desenvolvimento da personalidade e processo de subjetivação do homem" e "o homem e o mundo do trabalho". Depois se tornam mais específicas em direção aos "processos de adequação da personalidade ao ambiente de trabalho", "técnicas e métodos de transformação de grupos em equipes" e "administração de conflitos". Entendo que a presença de questões mais gerais possibilitaram o ensino da psicologia enquanto campo de conhecimento em suas diferentes interpretações e métodos e permitiram que Vinícius desenvolvesse nesta disciplina os temas: diferença entre ciência e senso comum; comportamento humano; trabalho; e personalidade. As questões mais específicas foram abordadas nos seminários ministrados pelos discentes, que desenvolveram os temas: trabalho em equipe; motivação; conflitos; e comunicação. Nas aulas Vinícius não abordou um dos temas previstos no Plano de Curso, "clima e cultura organizacional", e acrescentou o tema sobre a diferença entre ciência e senso comum. Compreendo que isso demonstra que, ainda que haja uma previsão e mecanismos de controle sobre os temas a serem desenvolvidos em sala de aula, há também brechas e possibilidades de escolha para o professor, evidenciando assim um certo grau de autonomia em sua sala de aula.

Entendo que os temas previstos no Plano de Curso e desenvolvidos nas aulas ministradas por Vinícius prezam por uma aproximação a uma psicologia de caráter mais geral e mesmo no Plano de Curso visam a que discentes possam compreender o processo de desenvolvimento humano. Já nos temas desenvolvidos pelos discentes, pela própria orientação de Vinícius, há uma preocupação em derivar dos mesmos formas como um "bom trabalhador" deva ser e agir.

Assim, considero que na disciplina e no Plano de Curso de técnico em Administração há uma preocupação, mesmo que pequena, com o ensino de 
conhecimentos para além de sua aplicabilidade técnica, contemplando conhecimentos que identifico como próximos a uma introdução à psicologia geral.

No entanto, entendo que a tendência a uma apropriação, ora mais prescritiva de formas de ser e agir ora mais instrumental - demandando a aplicabilidade técnica dos conteúdos -, tanto da Psicologia como de outros conhecimentos, vai se acentuando no curso de técnico em Administração com o decorrer dos módulos, pois em Gestão de Competências I, ainda que se determine que uma das bases tecnológicas seja o histórico da gestão de pessoas e relações de trabalho, posteriormente restringe-se os conteúdos ao modelo das competências regendo as ações (como já anunciado no nome da disciplina). E Gestão de Competências II reduz-se à instrumentalização e prescrição, prevendo como bases tecnológicas a delimitação do "papel do gestor" e "habilidades profissionais; competência técnica, criatividade, ética, comprometimento", ou seja, tem-se que mesmo nas bases tecnológicas prevê-se o ensino de uma forma de ser e agir que deve ser adquirida pelos discentes.

Diante dessas questões compreendo que a disciplina Psicologia Organizacional tem, no contexto do curso de técnico em Administração, um objetivo de introdução à Psicologia, versando sobre conteúdos que adquirirão características mais aplicáveis e prescritivas no decorrer do curso. Isso é consoante ao contexto geral do Plano de Curso de técnico em Administração, no qual é previsto para o início do curso uma ênfase na formação mais geral, que aborde aspectos históricos dos conhecimentos previstos, e aos poucos vai se direcionando a uma aplicabilidade que almeja que discentes saibam realizar as ações a serem desenvolvidas por técnicos em Administração e saibam se comportar no ambiente de trabalho.

Penso então que a disciplina de Psicologia Organizacional relaciona-se ao perfil do profissional esperado para o técnico em Administração no domínio de conhecimentos orientados por uma perspectiva toyotista, conforme vimos no capítulo sobre educação profissional.

Dado o caráter mais introdutório e geral da disciplina - e talvez também porque a mesma seja oferecida no início do curso -, Vinícius aborda os temas já explicitados acima predominantemente a partir de exemplos relacionados a aspectos da vida dos discentes, como escola, relacionamentos com os pais e amigos, paqueras e namoros e em menor frequência a partir de situações de trabalho. 
Nessa disciplina Vinícius e discentes parecem bastante motivados nos momentos em sala, e o relacionamento entre ambos baseia-se em condutas de respeito mútuo, o que permite a fluidez do diálogo em sala. Discentes da disciplina participam da aula, realizando perguntas, anotando os conteúdos da aula ou comentando questões pertinentes e por diversas vezes dizem que é o melhor dia de aulas da semana.

Considero assim que as características específicas da disciplina possibilitam a expressão de processos potencialmente emancipatórios ainda que, como analisarei a seguir, as condições gerais de trabalho docente condicionem 0 predomínio de processos potencialmente alienantes.

\subsubsection{Psicologia Social}

Também aqui situarei a disciplina de Psicologia Social frente ao que está previsto para ser desenvolvido no curso de técnico em Marketing e para a disciplina a partir de seu Plano de Curso, pois como discorri anteriormente este condiciona as expressões do ensino de psicologia. Em seguida apresentarei brevemente os temas desenvolvidos nas aulas observadas e pontuarei questões sobre relacionamento entre Vinícius e discentes, a fim de prover uma contextualização às questões que serão analisadas nos processos potencialmente alienantes e emancipatórios.

A partir de uma apreciação geral do Plano de Curso de técnico em Marketing, compreendo que há uma grande ênfase na restrição à aplicabilidade técnica dos conteúdos previstos, explícita, por exemplo, nos objetivos declarados para o curso, os quais preveem que o mesmo deva "capacitar para", e apresenta itens restritos ao domínio da técnica, como "aplicar e formular estratégias de marketing" e "utilizar técnicas mercadológicas".

No que diz respeito à área da Psicologia, ainda que o curso possua duas disciplinas que explicitam a existência de conteúdos psicológicos em seu nome Psicologia Comportamental e Psicologia Social, sendo a primeira de exclusividade do licenciado em Psicologia ministrar - nenhum dos técnicos que participaram de sua formulação possui formação em Psicologia. Em relação à bibliografia recomendada aos docentes do curso, nenhum título se refere explicitamente à Psicologia ou contempla autores fundadores de teorias nesta ciência. Penso que aliado ao contexto geral do Plano de Curso, esses fatores proporcionam uma 
apropriação da Psicologia por vias muito distantes da mesma, o que favorece o uso instrumental estabelecido para os conhecimentos psicológicos na disciplina de Psicologia Social.

Nessa disciplina Vinícius desenvolveu os temas: recrutamento e seleção; e treinamento e desenvolvimento. Nos seminários realizados pelos discentes, foram desenvolvidos os temas: normalização e aplicabilidade de recursos humanos; marketing pessoal e organizacional; aspectos comportamentais na gestão de pessoas; e administração do tempo.

Esses são alguns dos temas previstos no Plano de Curso para serem desenvolvidos na disciplina, estritamente relacionados às ações que se espera que seus concluintes saibam executar, como "participar de seleção, integração e treinamento de novos funcionários". Assim, os conteúdos desenvolvidos se relacionam ao perfil do profissional esperado para o técnico em Marketing, o qual, como vimos, traz no contexto geral de seu Plano de Curso uma restrição dos temas à sua aplicabilidade técnica imediata. No entanto também se prevê como bases tecnológicas os temas "estruturação do relacionamento humano" e "diversos tipos de personalidade e autoconhecimento". Porém, penso que como tais temas não guardam relações diretas com as competências previstas para serem desenvolvidas na disciplina, eles não foram contemplados no decorrer das aulas observadas, o que não deixa de indicar um processo de escolha de Vinícius em relação aos temas que desenvolve, evidenciando assim um certo espaço de autonomia.

Considero que as escolhas de Vinícius estejam relacionadas ao fato da disciplina compor o último módulo do curso - quando teoricamente discentes estão prestes a pleitear uma vaga no mercado de trabalho -, o que faz com que se imponham com mais força os mecanismos expostos nas condições de trabalho relativos ao apelo à empregabilidade dos concluintes do curso, que se refletem como apresentarei na análise dos processos potencialmente alienantes - em uma prescrição das formas como discentes deveriam se portar em situações de seleção e no ambiente de trabalho.

No que diz respeito às relações que se estabelecem entre Vinícius e discentes, no início do semestre os discentes da disciplina participam da aula, anotam, fazem perguntas pertinentes aos temas desenvolvidos e expõem compreensões diferentes da de Vinícius quanto às condutas que supostamente precisariam ter em processos de seleção e mesmo em um futuro emprego. Diante 
dos últimos questionamentos dos discentes, Vinícius reafirma as prescrições de condutas, encarando as posturas deles como ingênuas, o que ao longo do semestre produz um distanciamento dos discentes em relação à disciplina, evidenciado pelo fato de não mais formularem perguntas ou discordarem de Vinícius e de no momento da aula dedicarem-se a tarefas de outras disciplinas ou saírem frequentemente da sala para ir ao banheiro.

Considero que as características específicas da disciplina condicionam um predomínio ainda mais acentuado de processos potencialmente alienantes na mesma.

Defino, exemplifico e analiso as questões sinalizadas nesta breve apresentação com maior profundidade nos tópicos a seguir.

\subsection{Processos potencialmente alienantes: expressões e contribuições do ensino de psicologia nas Etecs}

Conforme discuti e defini nos esclarecimentos preliminares, considerei como processos potencialmente alienantes aqueles nos quais o ensino de psicologia dificultou a posse dos conhecimentos histórico-socialmente construídos, aprofundando o estranhamento na relação com o gênero; dificultou o estabelecimento de relações do homem com outros homens e consigo mesmo enquanto seres histórico-sociais; e subordinou os conhecimentos psicológicos aos interesses do capital, aprofundando a dissociação entre significado e sentido. A partir do processo de pesquisa de campo considerei que o ensino de psicologia expressou e contribuiu para processos potencialmente alienantes: 1) na redução do conteúdo a seu uso instrumental; 2) na marginalidade dos conteúdos; 3) na ênfase em prescrições de formas de ser e agir; e 4) nos equívocos no ensino de conteúdos.

\subsubsection{Redução dos conhecimentos psicológicos ao uso instrumental}

No capítulo sobre educação profissional sinalizei a histórica dissociação entre saberes acadêmicos e saberes práticos, e que na mesma os saberes práticos eram reduzidos, interessando apenas a parte da qual se extrai uma aplicabilidade técnica imediata. Cabe esclarecer que entendo que em um curso profissional exista a preocupação de que os formandos dominem os conhecimentos técnicos requeridos 
para o exercício de sua profissão. A redução de todo o conhecimento a essa dimensão aplicável, que recusa a dúvida e a reflexão, aparando arestas e apresentando o conhecimento como algo acabado, é que é considerada como instrumental.

Como vimos na caracterização da disciplina de Psicologia Social e analisamos nas condições de trabalho docente, o Plano de Curso de técnico em Marketing, especialmente no que se refere à disciplina de Psicologia Social, prevê uma estreita vinculação das bases tecnológicas à sua aplicabilidade técnica. Isso condiciona que no ensino de psicologia dessa disciplina os conteúdos ministrados guardem relações estritas com sua aplicabilidade, desconsiderem processos históricos, matrizes teórico-filosóficas, e vinculações ideológicas. Nessa disciplina a Psicologia era reduzida a uma de suas partes, abrangendo conhecimentos tradicionalmente vinculados à psicologia organizacional, restritos a suas facetas ideológicas e visando à aplicabilidade imediata dos conteúdos.

Como expus nas condições de trabalho os temas desenvolvidos nesta disciplina por Vinícius foram recrutamento e seleção, e treinamento e desenvolvimento. A forma ideológica como foram abordados pode ser exemplificada na definição de seleção como tendo por finalidade "achar o homem certo para o cargo certo", ainda que num dado momento Vinícius aponte que a seleção sempre envolve "margem de erro", pois envolve relações humanas. Considero tal definição de seleção como ideológica porque se limita ao discurso organizacional, oculta todo um contexto de desemprego estrutural e não desvenda os mecanismos que supostamente determinariam o que é ser "o homem certo para o cargo certo".

Em todos os temas as definições são como a exemplificada acima, superficiais e a-históricas, e então passa-se a abordar as técnicas sobre como realizar recrutamento, seleção, treinamento e desenvolvimento, ensinando os procedimentos: como preencher uma requisição de empregado, onde e como conduzir uma entrevista, como planejar e executar um treinamento, entre outros. Tudo tem um padrão "correto" que deve ser obedecido, sempre a partir do referencial de grandes empresas, de preferência multinacionais, como se todas tivessem uma mesma forma de funcionamento e como se desde sempre os procedimentos tenham sido executados da forma como ensinados.

A desconsideração dos processos históricos pode ser exemplificada ao ministrar-se nas aulas que a seleção é composta de uma diversidade de 
procedimentos - que seriam a entrevista, a dinâmica de grupo, a aplicação de testes psicológicos e provas de conhecimento geral, específico e situacionais - como se sempre tivesse utilizado os mesmos procedimentos e justificando-se e naturalizando-se, por exemplo, o uso de redes sociais para pesquisa sobre os candidatos.

As atividades em sala, que acabam funcionando como procedimentos avaliativos dos discentes, na aparência objetivam verificar se discentes conseguem planejar ações de acordo com as etapas e procedimentos ministrados, ou seja, se adquiriram o domínio da técnica. Um exemplo é a solicitação do planejamento de um treinamento e outro é o planejamento e execução de um processo seletivo fictício. Enfatizo, essa é a aparência, pois veremos que o uso instrumental desses conhecimentos pode ocultar outra ênfase.

Essa tendência ao domínio da técnica é condicionada pelo apelo à mesma existente na própria Etec. Como se pode ver no Plano Plurianual de Gestão da Etec campo desta pesquisa, as metas da escola se vinculam predominantemente às demandas de reestruturação de seus espaços físicos (biblioteca, reforma e criação de laboratórios) e à manutenção dos recursos tecnológicos (manutenção de computadores, criação de site para socialização de informações) e muito marginalmente à qualidade do ensino oferecido. Um exemplo retirado deste plano e que ilustra a questão do predomínio da técnica é que, quando discentes apontam insatisfação com a didática dos docentes, a forma de intervir é pela capacitação dos professores para o domínio dos recursos tecnológicos existentes na escola, "incorporando em seu dia-a-dia formas mais atuais de ensino-aprendizagem e que atendam melhor as expectativas dos alunos". Compreendo que assim reduz-se a relação pedagógica ao domínio dos recursos técnicos e os docentes a meros bons ou maus utilizadores desses recursos, o que é consoante ao que está posto nas condições de trabalho dos professores nas Etecs, pois a hierarquia e cerceamento da autonomia docente nas formas como se impõe o que deve ser feito pelos mesmos, como já apresentado no item 4.2, converge para a redução destes a meros técnicos, que devem apenas executar o que já foi pensado centralizadamente.

Penso que, ao longo do tempo, de tanto se naturalizar que o domínio da técnica é que importa, ele acaba reproduzido por Vinícius no ensino de psicologia nesta disciplina, pois os conteúdos na aparência buscam reduzir discentes a bons 
executores de técnicas prontas e acabadas. A compreensão do que tais técnicas significam - porque começaram a ser utilizadas e quais as possíveis consequências no uso das mesmas - são aspectos que não interessam e acabam excluídos do âmbito do ensino, reduzindo assim os conhecimentos ao seu mero uso instrumental. Ou seja, colocam-se os conhecimentos como não tendo fins de desenvolvimento humano, de proporcionar análises críticas, mas somente que discentes saibam executar as ações requeridas para o exercício da profissão, o que, como vimos no item 4.2, parece estar naturalizado no âmbito das Etecs, sendo excluído o objetivo intencional de formação humana crítica.

No entanto, ainda que a redução dos conhecimentos a seu uso instrumental esteja presente no ensino de psicologia na disciplina de Psicologia Social, nas condições de trabalho nas Etecs, no Plano Plurianual da Etec campo desta pesquisa, nos Planos de Curso e na estrutura dos Planos de Trabalho Docente, não vi indícios de tal uso na disciplina de Psicologia Organizacional o que atribuo ao fato de - como visto na caracterização desta disciplina e que ficará mais claro no item 4.4.2 - nesta não haver subordinação das bases tecnológicas à sua aplicabilidade técnica.

Um exemplo que resgata as diferenças entre os Planos de Curso (apresentadas nas condições de trabalho) e ilustra tanto a abrangência curricular diferenciada como a restrição dos conteúdos à sua aplicabilidade predominante no Plano de Curso de técnico em Marketing quando comparado ao Plano de Curso de técnico em Administração, é a comparação entre uma mesma disciplina presente nos dois cursos - Ética e Cidadania Organizacional. Como vimos no item 2.4.1, essa disciplina está presente na maioria dos cursos técnicos nas Etecs e pode ser ministrada pelo licenciado em Psicologia em grande parte deles, mas, ainda que tenha o mesmo nome, as características previstas em cada um desses Planos podem ser bem diversas. Quando comparamos essa disciplina entre os Planos de Curso de técnico em Administração e os em Marketing, encontramos a previsão de algumas competências comuns. No entanto, as bases tecnológicas para o curso de técnico em Administração são bem mais abrangentes, incluindo estudos sobre cultura além de conceitos e fundamentos de ética geral, enquanto no curso de técnico em Marketing as bases tecnológicas restringem-se a códigos, regulamentações, técnicas e conceitos de trabalho em equipe, cooperação, autonomia pessoal e critérios de imagem pessoal e organizacional. 
Considero que isso nos auxilia a entender a redução dos conhecimentos psicológicos ao uso instrumental presente na disciplina de Psicologia Social, para a qual contribui ainda o fator de que, como vimos nas condições de trabalho, nenhum dos formuladores do Plano de Curso de técnico em Marketing possuir formação em Psicologia e mesmo a bibliografia recomendada aos docentes não se referir explicitamente à ciência psicológica, o que indica que os próprios formuladores provavelmente tenham uma aproximação da psicologia somente por meio de sua aplicação instrumental, condicionando que seja por essa via que os conhecimentos psicológicos se encontrem inseridos no curso de técnico em Marketing.

Essa redução do conhecimento a seu uso instrumental pode indicar a persistência, nas escolas técnicas estaduais, especialmente no curso de técnico em Marketing, de características das primeiras regulamentações da educação técnica nas quais - como vimos no item 1.3, segundo Schwartzman, Bomeny e Costa (1984) - prevaleceu a perspectiva do Ministério do Trabalho: a ênfase na técnica com vistas a suprir as necessidades práticas imediatas. Assim, ainda que no âmbito dos ideários pareça ter havido transformações na educação profissional, esta continua a carregar e expressar a perspectiva vencedora daquela época. Para Ramos (2006, p. 222) essa é uma dimensão ainda esperada do ensino técnico, no qual a validade dos conhecimentos é dada por sua aplicabilidade ao exercício de atividades na produção de bens materiais ou serviços.

Entendo que a expressão do domínio da técnica esteja condicionada ainda a um clima cultural no qual prevalece, segundo Horkheimer e Adorno (1985), a razão instrumental, na qual se atribui valor ao conteúdo à medida que deste pode-se extrair vantagem ou lucro, excluindo a possibilidade do mesmo ter qualidades próprias (independente de sua aplicabilidade), possibilitar o desenvolvimento do indivíduo e do gênero humano. Ou seja, entendo que claramente se assume uma posição política de que o conteúdo deva servir aos interesses do capital.

Considero que, desvendados os mecanismos que contribuem para a redução dos conhecimentos psicológicos ao uso instrumental no contexto singular das aulas de Psicologia Social observadas, é possível inferir que o mesmo ocorra nas outras disciplinas que podem ser ministradas pelo licenciado no curso técnico de Marketing em todas as Etecs, desvelando-se assim sua dimensão universal.

Compreendo o processo de redução dos conhecimentos psicológicos ao uso instrumental como potencialmente alienante porque ao restringir o conhecimento à 
sua aplicabilidade constrói-se uma barreira ao entendimento dos conteúdos abordados, ocultando o seu processo histórico de desenvolvimento, naturalizando as formas de aplicabilidade à sua expressão atual, dificultando assim ainda mais a relação do indivíduo com o gênero humano.

Também, ao restringir-se o conhecimento à sua dimensão que interessa a obtenção de lucro e a manutenção das desigualdades sociais, numa identificação imediata entre conteúdos e sua aplicabilidade, legitima-se que o sentido do conhecimento esteja vinculado ao sentido que tem para a sociedade capitalista e desvincula-o do significado atrelado a finalidades humanas, contribuindo para o aprofundando da alienação no que diz respeito à consciência.

\subsubsection{Marginalidade do conteúdo}

Ainda que haja conhecimentos psicológicos ministrados na aula de Psicologia Social com vistas a uma aplicabilidade técnica, isso não garante que assumam centralidade no processo educativo. Observei, seja nas aulas de Psicologia Social, seja nas aulas de Psicologia Organizacional, momentos em que a presença ou ausência do conteúdo ministrado não alteraria o objetivo principal das aulas. A este espaço secundário que o conteúdo - instrumental ou o saber acadêmico - ocupava em determinadas ocasiões nomeei como marginalidade do conteúdo. Importante lembrar que as expressões do ensino de psicologia a seguir exemplificadas estão profundamente condicionadas pelas condições de trabalho, neste caso especialmente em relação aos objetivos postos para as Etecs, que conforme pontuei anteriormente não se vinculam à formação humana crítica dos discentes, mas estão profundamente submissos às demandas de um certo tipo de trabalhador que se adeque à instabilidade e fluidez das relações atuais de trabalho.

A marginalidade dos conteúdos foi observada tanto nas aulas de Psicologia Social quanto de Psicologia Organizacional, porém era mais acentuada na primeira do que na segunda, pois se na disciplina de Psicologia Social a marginalidade do conteúdo foi identificada em todas as aulas, na disciplina de Psicologia Organizacional foi inferida especialmente nos seminários realizados pelos discentes e nos recursos utilizados.

Essa diferença fica explícita quando Vinícius utiliza o mesmo recurso - um vídeo sobre trabalho, produzido pela Secretaria de Emprego e Relações do 
Trabalho. Na aula de Psicologia Organizacional exibe-o em sua totalidade (que como veremos adiante tem conhecimentos sobre o processo histórico de desenvolvimento das relações de trabalho) e na aula de Psicologia Social restringeo à última parte, que aborda um passo a passo do que fazer para conseguir um emprego, negligenciando os aspectos de conhecimentos históricos e conceituais que poderiam estar presentes. Como veremos a seguir, essa conduta de Vinícius está profundamente relacionada às formas de ser e agir que se espera que os discentes adquiram, em especial porque os mesmos estariam às vésperas de candidatarem-se a um emprego, e o índice de empregabilidade é um dos indicativos da qualidade de ensino nas Etecs.

A marginalidade do conteúdo pode ser inferida ainda nas situações de seminários dos discentes a partir de diversos indicativos. Um deles é a ordem de prioridade que conteúdos assumem para Vinícius e discentes, explicitada quando em uma aula de Psicologia Social os discentes perguntam o que Vinícius considera como seminário. Após os discentes dizerem o que não caracterizaria um seminário, Vinícius passa a descrever o que o compõe, e fala de posturas corporais adequadas, da não utilização de vícios de linguagem, da forma apropriada de se vestir, da necessidade de utilização de recursos e apenas por último aponta que é preciso embasamento bibliográfico.

O outro indicativo de marginalidade dos conteúdos nos seminários é que na disciplina de Psicologia Organizacional o feedback de Vinicius aos discentes só incidiu sobre o conteúdo quando considerou que houve excesso do mesmo. $\mathrm{Na}$ aula de Psicologia Social não era realizado esse feedback, então a questão não foi observada.

A não explicitação das referências bibliográficas utilizadas pelos discentes nos seminários é outro indicativo da marginalidade dos conteúdos nos mesmos. Apenas dois grupos indicaram tais referências, na disciplina de Psicologia Social, e Vinícius não solicitou tal explicitação. Ao realizar pesquisa com auxílio da ferramenta de busca Google percebi que a maioria dos seminários havia se baseado nos primeiros sites resultantes da pesquisa a partir do título do seminário. Trechos, slides e por vezes sequências inteiras simplesmente reproduzidas no seminário, sem reconhecer o que o outro produziu e tampouco considerar quais sites poderiam ser considerados fonte legítima de conhecimento científico. Assim, infiro que as questões conceituais e o embasamento teórico não tinham centralidade para a 
realização dos seminários e que o ensino de habilidades de pesquisa e formas de construção do conhecimento científico também não era objetivo dos mesmos. Penso que a não atribuição de créditos ao autor, além de indicar a marginalidade do conteúdo, denota ainda o ensino de um descompromisso ético, pois ao não reconhecer ao outro o que o mesmo produziu privo-o de sua condição de autor.

Outro fator que indica a marginalidade dos conteúdos nas duas disciplinas é a inexistência nas aulas de textos originais dos teóricos abordados e escassez de referências bibliográficas utilizadas durante as mesmas. Os textos utilizados como recurso didático durante as aulas ou foram construídos por Vinícius ou foram retirados da internet. No segundo caso o local de onde os textos foram retirados não é referenciado e em ambos os casos as referências que embasaram a construção dos textos não são explicitadas. Mesmo no Plano de Trabalho Docente, no local onde Vinícius listaria a bibliografia a ser utilizada nas disciplinas, isto não foi realizado na disciplina de Psicologia Social. Na disciplina de Psicologia Organizacional foi listado um livro chamado Cidadão de pape ${ }^{47}$, o qual não foi usado na disciplina. A única referência bibliográfica existente, e repetida em aula, é a recomendação de leitura do livro 0 corpo fala ${ }^{48}$. Entendo que essas questões acabam por reduzir a visão dos discentes à de Vinícius, dificultam o acesso a textos acadêmicos originais, embasados cientificamente, e indicam a pouca relevância dada aos conteúdos no âmbito das disciplinas observadas. Ao mesmo tempo, o fato de que as referências bibliográficas listadas no Plano de Trabalho Docente não constam na bibliografia recomendada nos Planos de Curso de técnico em Administração e de técnico em Marketing, revela que por mais que haja um cerceamento da autonomia quanto às competências, habilidades e bases tecnológicas para cada disciplina, há brechas que permitem a inclusão de referências bibliográficas diversas das previstas na elaboração centralizada dos Planos de Curso e assim de compreensões que se distanciem da aplicabilidade imediata dos conteúdos, o que, no entanto, não se concretizou em sala de aula.

A questão da marginalidade do conteúdo ser mais acentuada na disciplina de Psicologia Social que na de Psicologia Organizacional ficará mais explícita quando

47 Apesar de não constar no Plano de Trabalho Docente a referência completa, infiro que seja o livro do jornalista Gilberto Dimenstein, no qual expõe as desigualdades do país.

48 Também neste caso infiro que seja o livro de Pierre Weil e Roland Tompakow, no qual se atribui significados a gestos, posturas, enfim a expressões de comunicação não verbal por meio do corpo. 
falarmos da prevalência da prescrição de formas de ser e agir, pois onde o conteúdo é relegado ao segundo plano ele dá lugar privilegiado a essas prescrições. Como uma questão está intrinsecamente relacionada a outra, analisarei os determinantes das mesmas em conjunto no próximo tópico - após explicitar e exemplificar o que tenho chamado de prescrição de formas de ser e agir -, buscando a universalidade dessas expressões no ensino de psicologia nas Etecs.

Contudo, antes de fazê-lo cabe esclarecer o porquê entendi que a marginalidade dos conteúdos é um dos processos potencialmente alienantes no ensino de Psicologia. Ora, ao conteúdo ser relegado ao segundo plano, nega-se ao discente que do mesmo se aproprie. Ao não lhe prover referências de fontes nas quais poderia se apropriar de conhecimentos, nega-se duplamente a possibilidade de apropriação dos mesmos. Nega-se assim o acesso a recursos pelos quais 0 discente poderia se apropriar de conhecimentos que o enriquecessem como ser humano. Por fim, nesse processo legitima-se que os conhecimentos nada the acrescentam, dando indícios de que a relação dos discentes com os conhecimentos é descartável, e assim a relação com o gênero torna-se descartável também, constituindo, no meu entender, um processo que potencialmente contribui para o aprofundamento da alienação.

\subsubsection{Prescrição de formas de ser e agir}

Entendi como prescrição de formas de ser e agir a explicitação verbal ou escrita de condutas a serem adotadas ou evitadas por discentes e docentes. A prescrição, junto à marginalidade do conteúdo, será compreendida a partir das políticas públicas estaduais e federais para a educação profissional técnica, a ideologia presente acerca do mundo produtivo, as demandas em relação ao ajustamento das subjetividades, as questões de formação docente e sua carga horária de trabalho. Nesse movimento a expressão singular do ensino de psicologia na Etec, desvendados seus determinantes, permitirá inferir que os processos que implicam na marginalidade dos conteúdos, bem como na prescrição de formas de ser e agir condicionem as expressões do ensino de psicologia nas Escolas Técnicas Estaduais de São Paulo, explicitando assim seu caráter universal.

Observei que, assim como a marginalidade do conteúdo, a ênfase na prescrição de formas de ser e agir se expressava mais acentuadamente na 
disciplina de Psicologia Social, na qual as falas eram recorrentemente sobre a forma como discentes deveriam se portar em situações de seleção e no ambiente de trabalho. Nas aulas de Psicologia Organizacional, a prescrição de formas de ser e agir era pouco presente nas aulas ministradas por Vinícius, mas recorrentes nos seminários ministrados pelos discentes.

Por exemplo, na aula de Psicologia Social, Vinícius propagava que o tipo de funcionário que a empresa quer é alguém polivalente, pró-ativo, não se diferenciando do discurso empresarial, muito pelo contrário, legitimando-o como verdade. Recomendava como fonte de conhecimento as palestras motivacionais disponíveis no YouTube - de Daniel Godri Junior, o qual parte de sua experiência empresarial, sem explicitar qualquer vinculação teórica, e apregoa que a chave do sucesso é "focar-se nas coisas boas" e ignorar as dificuldades e fontes de sofrimento presentes no trabalho.

Também na aula de Psicologia Social, ao desenvolver as questões sobre recrutamento, seleção, treinamento e desenvolvimento - apesar de como visto serem abordadas técnicas para realização desses procedimentos -, a ênfase na fala de Vinícius recaía sobre como discentes deveriam se portar, dizendo para não usar piercing, não ter tatuagens, trajar-se socialmente, utilizar sapato fechado, e, em situações de seleção, "se não gosta de algo, como dinâmica de grupo, no dia da seleção deve adorar" e "falar a língua da empresa e não expressar desacordo com posturas e políticas da mesma".

Compreendo a ênfase nesses tipos de fala pelo próprio ambiente social que vivemos, nos quais somos constantemente bombardeados por receitas prontas que nos dizem como ser, presentes nos meios de comunicação, como discutimos nas questões envolvendo as condições de trabalho. Porém, ao reproduzir tais falas, Vinícius propaga caricaturas de formas de ser e agir que são consoantes às imagens e à ideologia já exaustivamente difundidas pela mídia como garantia de colocação e manutenção no mercado de trabalho, em nada se distanciando das mesmas, mas naturalizando-as como verdade, por vezes piorando-as por não as relacionar as características específicas de cada ambiente de trabalho e muito menos as contextualizando frente a uma sociedade de desemprego estrutural. Compreendo que essas informações são veiculadas e reafirmadas tão exaustivamente, e em condições de trabalho que dificultam a Vinícius afastar-se delas e refleti-las criticamente, que o mesmo adere e reproduz as questões com as 
quais é bombardeado, mesmo porque elas gozam de certo prestígio e legitimação social. No entanto, ao fazê-lo, Vinícius nada acrescenta àquilo que estamos tão expostos e legitima tais falas como conhecimentos válidos, conferindo as mesmas um suposto embasamento científico.

Outro exemplo que explicita a prevalência da prescrição de formas de ser e agir é em um exercício solicitado aos discentes da disciplina de Psicologia Social. Este envolvia que um grupo de discentes planejasse e executasse um processo seletivo e os outros discentes fariam o papel de "candidatos". Embora na aparência houvesse a aplicabilidade dos conteúdos ministrados em aula quanto às etapas que envolvem um processo seletivo, a forma como foi desenvolvido indica que os procedimentos técnicos não eram relevantes, pois a coerência do conjunto do processo não é considerada pelos "selecionadores" nem por Vinícius, que ao comentar sobre o "processo seletivo" aborda aspectos sobre os comportamentos dos "candidatos". Entendo que isso sugere que o objetivo do exercício era que discentes vivenciassem uma situação de seleção e a partir dela Vinícius pudesse sinalizar os comportamentos certos e errados que supostamente lhes auxiliariam ou prejudicariam em uma situação de seleção na qual fossem candidatos, o que compreendo estar condicionado pelo apelo à empregabilidade presente no Centro Paula Souza - mais presente à medida que discentes se aproximam da conclusão do curso, conforme apontado no item 4.2.

Nos seminários, seja nas aulas de Psicologia Social ou Psicologia Organizacional, os discentes desenvolviam um tema previamente designado, partiam de aspectos conceituais, em geral de forma superficial (com algumas exceções), e passavam a enfatizar uma sequência de prescrições do que se deve ou não fazer.

Por exemplo, no seminário sobre marketing pessoal (disciplina de Psicologia Social), definiu-se o termo como "a imagem que você constrói e passa para se vender". Os discentes apresentam então o que chamam de "dez mandamentos do marketing pessoal", como liderança, maturidade, integridade, todos relacionados ao perfil de "personalidade", do que se deve ser, retirados de um vídeo de Max Gehringer no site YouTube.

Outro exemplo, agora na aula de Psicologia Organizacional, foi no seminário sobre conflitos, quando o título adotado pelos discentes foi "Como manejar conflitos e suas possíveis causas e consequências". Ainda que na definição o termo "conflito" 
não necessariamente fosse caracterizado como algo ruim, as prescrições eram as formas de evitá-lo no trabalho (mostre-se superior, tenha sempre alguém ao seu lado etc.), de resolvê-los no trabalho (esclareça percepções, olhe para o futuro etc.) e de lidar com eles (não dê atenção às críticas, aceite opiniões alheias etc.).

Vinícius ouve atentamente os discentes durante os seminários, e se há algo que julgue precisar ser esclarecido ou que não esteja sendo abordado, intervém com perguntas ou afirmações para esclarecer ou introduzir as questões que julga pertinentes. No caso da aula de Psicologia Social, não há feedback aos discentes. $\mathrm{Na}$ aula de Psicologia Organizacional, ao final de cada seminário Vinícius reúne os discentes ministrantes e realiza feedback do desempenho geral do seminário, apontando a cada discente o que havia feito de positivo e o que poderia melhorar, abordando predominantemente questões relativas à linguagem verbal e não-verbal, bem como a utilização dos diferentes recursos pelos discentes. Entendo assim que a função predominante dos seminários não se vinculava às prescrições aos outros discentes muito menos ao conteúdo porventura abordado nos mesmos, mas sim à observação e à avaliação dos comportamentos verbais e não verbais dos ministrantes dos seminários e o quanto estavam adequados ou não ao padrão exigido, supostamente para melhor veicular ideias e convencer os outros discentes, bem como adequar-se ao mundo profissional. Isso se confirma quando na reunião de pais fala-se dos seminários e da exigência dos discentes virem vestidos formalmente no dia dos mesmos. Vinícius diz que assim ensina os discentes a como se portar num contexto profissional e outros docentes acrescentam que aquela Etec é procurada por empresas da região para indicar estagiários, alegando que o diferencial desta Etec é que discentes saem não só com conhecimentos técnicos, mas sabem se comportar na empresa. Isso nos lembra que a ênfase em prescrições de formas de ser e agir é algo esperado na Etec, o que torna Vinícius um profissional valorizado naquele contexto e o mantém realizando tais práticas.

Cabe lembrar que muito embora a prescrição seja mais acentuada na disciplina de Psicologia Social, o que entendo como potencialmente alienante, boa parte dos discentes que a frequentam resistem a essa prescrição e constantemente a questionam, apontando especialmente que nas áreas profissionais em que pretendem atuar as normas quanto a vestir-se formalmente e não ter piercings e tatuagens são menos rígidas. Diante dos questionamentos dos discentes, Vinícius reafirma as prescrições, o que ao longo do semestre vai provocando um 
distanciamento dos discentes, percebido pelo engajamento em outras atividades durante a aula, conforme apontei nas condições de trabalho específicas a esta disciplina. Assim, compreendo que discentes não necessariamente aderem a essas prescrições e possivelmente se ressentem da falta de outros conhecimentos que inclusive Ihes possibilitariam embasamento para questionarem, criticarem e contraporem-se a prescrições de forma de ser e agir não só no contexto escolar, mas também no contexto social mais amplo. Essa seria uma questão a ser melhor investigada em outra pesquisa.

Conforme sinalizei ao longo do texto, considero que as condições de trabalho do professor convergem para a marginalidade dos conteúdos e para as prescrições de formas de ser e agir. De tanto ser reduzido a um técnico, conforme expus anteriormente, o docente acaba se resignando a esta condição e realizando aquilo que dele se espera. A marginalidade e as prescrições são consoantes ao previsto nos Planos de Curso, que estabelece precedência das competências em relação às bases tecnológicas, estritamente subordinadas às primeiras. Como vimos especialmente no capítulo sobre educação profissional, as competências aparecem nas políticas públicas de educação enfatizando aspectos da subjetividade e da individualidade do trabalhador e ainda que isso pudesse proporcionar o resgate de dimensões humanas outrora negadas no trabalho, acaba por acentuar processos de adequabilidade dessas dimensões antes humanas para fins de maximização do lucro. E mesmo que nos Planos de Curso haja uma imprecisão do uso do termo "competência", em especial quando contraposto à habilidade - o que, como aponta Oliveira, M. (2002), ocorre no âmbito dos documentos normativos do Ministério da Educação para a educação, em especial a profissional -, ela é tomada como eixo ordenador do processo didático, privilegiando no campo das Etecs uma abordagem subjetivista e prescritiva de formas de ser e agir. Para Ramos (2006) a ênfase na competência desloca a importância do domínio de conceitos e conhecimentos, ratificando o papel da educação mais em relação à "conformação da personalidade e da consciência do que dos conhecimentos técnicos e científicos" (p. 275).

Assim, compreendo que a marginalidade do conteúdo e a prescrição de formas de ser e agir são condicionadas ao previsto pelas políticas públicas de educação, e as demandas da sociedade capitalista analisadas no capítulo sobre educação profissional, com a exacerbação da valorização de características 
individuais - de uma subjetividade adaptável e flexível ao sabor do setor produtivo em detrimento de características formativas.

Cabe destacar que essa prescrição de formas de ser e agir não se restringe apenas aos discentes, mas possivelmente seja fruto de uma reprodução da prescrição que existe no âmbito das Etecs para os docentes. Como vimos, os docentes não podem opinar sobre os Planos de Curso, e prescreve-se que eles devam em seu Plano de Trabalho Docente apenas reproduzir o que está previsto no Plano de Curso. Vinícius é reduzido a um técnico que, como visto, deve obedecer e executar aquilo que foi planejado centralizadamente, sendo submetido a mecanismos de controle que visam a garantir que isso ocorra. Mesmo que existam brechas a essas imposições, ao longo do tempo Vinícius não mais as vê, pois essa tecnicização do trabalho do docente, o cerceamento de sua autonomia, acarreta em um distanciamento de Vinícius em relação ao seu trabalho e na ausência da atribuição de um sentido pessoal àquilo que ministra. Isso é explicitado por ele mesmo na entrevista, pois quando perguntado sobre as diferenças entre as disciplinas Psicologia Organizacional e Psicologia Social, diz que elas existem porque faz aquilo que está previsto no Plano de Curso e que tem de seguir o que está lá previsto. Se fosse intervir, diz que tornaria os conteúdos ainda mais técnicos. Essa consideração de Vinícius é interessante, especialmente quando contrastada com sua resposta sobre o papel do ensino de psicologia no ensino médio propedêutico: o papel de proporcionar crítica. Entendo assim que o cerceamento da autonomia, além de produzir um estranhamento de Vinícius quanto ao seu processo de trabalho, o conduz a uma legitimação da dualidade histórica do ensino de nível médio, assimilando-a e reproduzindo-a acriticamente.

Vinícius ao ser reduzido a simples técnico é despossuído de seu processo de trabalho, expresso também em seu distanciamento em relação a algumas de suas atividades, como por exemplo, a de avaliação. Vinícius considera que deveria haver um técnico responsável pela correção das avaliações, as quais se convertem em obrigação burocrática e objetivam a atribuição de "notas",49, não um acompanhar do processo de aprendizagem dos discentes, não sendo realizado feedback individual ou grupal sobre o que a atividade avaliativa revelou. No entanto, penso que isso

49 Optei pelo uso do termo "notas" para tornar mais clara minha exposição e não gerar duplo sentido com o que tenho analisado em relação à dimensão conceitual do ensino de psicologia, porém nas Etecs as avaliações dos discentes são expressas por meio de conceitos ("muito bom", "bom" etc.). 
também pode ser um pedido de ajuda por alguém que auxilie nas atividades docentes, especialmente pela carga horária de trabalho que dificulta a Vinícius poder realizar tais apreciações uma vez que já tem que se desdobrar e dedicar "horas extras não remuneradas" para atribuir "notas" a cada atividade avaliativa.

Da mesma forma que a prescrição de formas de ser e agir está mais presente na disciplina de Psicologia Social, o estranhamento de Vinícius em relação à sua prática profissional também parece ser mais acentuado nessa disciplina. Entendo isso porque nesta quase sempre se ausentava da sala durante o período que os discentes realizavam as atividades propostas, e aos poucos eles não mais se empenhavam na realização das mesmas - e Vinícius também não mais intervinha. No meu entendimento, ao longo do semestre, há uma progressiva diminuição de motivação de Vinícius e dos discentes para com a disciplina. Ainda na disciplina de Psicologia Social, no meu entender, Vinícius demonstrava também menor paixão pelo conteúdo ministrado, percebido até por sua demonstração de ressentimento em relação ao processo de atribuição de aulas para o ano de 2011, no qual teve de tornar- se responsável pelas aulas no curso de técnico em Marketing e não ter conseguido a aula de Psicologia Organizacional ${ }^{50}$.

Entendo que a maior incidência da marginalidade do conteúdo e de prescrições de formas de ser e agir, além do maior estranhamento de Vinícius em relação a suas ações na aula de Psicologia Social, estejam relacionados às possibilidades previstas no Plano de Curso de técnico em Marketing para esta disciplina, que como vimos anteriormente prevê temas mais restritos a uma área da psicologia, reduzindo assim as possibilidades de Vinícius discorrer amplamente sobre a psicologia. Outro fator que penso também condicionar tais expressões é a maior força com que se expressa o apelo à empregabilidade em uma disciplina ministrada no semestre em que discentes concluirão a formação profissional, conforme havia pontuado nas condições de trabalho.

Penso que a prescrição de formas de ser a agir aos professores, que resultam na alienação de Vinícius em relação ao seu processo de trabalho e ao longo do tempo em conformação e adesão ao prescrito, refletem-se no aprofundamento de

50 Importante esclarecer que isso ocorreu não como medida punitiva a Vinícius, mas porque um docente de Psicologia que até então estava afastado na direção de outra Etec teve seu acúmulo de cargos negado por critérios legais e assim teve de voltar para sala de aula. Como esse docente está melhor classificado (por critérios que envolvem entre outras coisas tempo de magistério), ele tinha a preferência na escolha das disciplinas. 
processos potencialmente alienantes dos discentes, que ficam ainda mais reféns das ideologias e prescrições produzidas centralizadamente pelo Centro Paula Souza, as quais são consoantes com o que vimos no capítulo sobre educação profissional e com a hipótese de Ferreti e Silva Júnior (2000) de que a educação profissional hoje objetiva mais a produção de um novo tipo de homem do que efetivamente uma preparação para o mercado de trabalho. Assim, mais do que o que explicitamente se prescreve, enfatiza-se ao discente que é sua dimensão subjetiva que importa e que esta é dependente única e exclusivamente do sujeito, buscando transferir-se a este a responsabilidade por seu sucesso ou fracasso, ocultando as condições de desemprego estrutural.

Estes condicionantes aqui elencados - Planos de Curso, prescrição ao docente, jornada de trabalho, políticas públicas para educação profissional consoantes ao trabalhador que se quer produzir, carga horária de trabalho docente estão presentes em todas as Etecs, o que me permite inferir que a marginalidade do conteúdo e as prescrições de formas de ser e agir observadas na realidade singular e aqui discutidas se expressem na universalidade do ensino de psicologia das Etecs.

Tais expressões do ensino de psicologia contribuem para o aprofundamento de processos potencialmente alienantes porque ao conformar o indivíduo a agir de acordo com o que foi prescrito distancio o indivíduo do relacionamento com o outro; o outro não importa, pois só me relaciono com este a partir das formas de ser e agir que já foram prescritas. Penso que isso se aproxima do que Adorno (1995a) caracteriza como processos que fortalecem a inaptidão à experiência, nos quais camadas estereotipadas se interpõem entre si mesmo e aquilo a ser experienciado, o que traz obstáculos à formação humana.

Por fim, tais processos seriam potencialmente alienantes também porque, ao prescrever formas de ser e agir, retira-se a dimensão social e histórica das relações humanas, naturalizando o que é social, rompendo o relacionamento com o gênero e conformando os discentes à aceitação passiva das condições atuais do trabalho estranhado.

\subsubsection{Equívocos no ensino de conteúdos}


Entendi como ocorrência de equívocos no ensino de conteúdos os momentos em que estes foram desvinculados do escopo da teoria ensinada e relacionados a terminologias e conceitos estranhos à mesma.

Importante lembrar que as expressões do ensino de psicologia a seguir exemplificadas estão profundamente condicionadas pelas condições de trabalho, em especial a dificuldade de apropriação da vastidão e complexidade do campo de conhecimento da psicologia; o local marginal relegado à formação de professores; a carga horária de trabalho docente; a escassez de discussões da categoria profissional da psicologia sobre ensino de psicologia em escolas técnicas; e de processos de formação continuada na qual se reflitam quais conteúdos e de quais formas os mesmos poderiam ser apropriados na educação profissional.

Observei que o equívoco no ensino de conteúdos era presente na maioria dos momentos da aula de Psicologia Organizacional. Uma das suas expressões ocorreu em relação à teoria comportamental no que diz respeito à análise do comportamento operante e aos conceitos de punição e reforço negativo. Ao explicar o comportamento operante, Vinícius utilizou o conceito de ciclo do comportamento (estranho ao Behaviorismo Radical) como composto por estímulo, resposta e reforço (componentes do comportamento operante, ainda que a unidade de análise básica do comportamento seja estímulo-resposta-consequência) e tomou-os como equivalentes a conceitos psicanalíticos, como "resposta" equivalendo a "desejo", ou a outros conceitos também estranhos à teoria comportamental, como "estímulo" a "causa" e "reforço" a "objetivo". O conceito de punição foi apresentado como sinônimo de "extinção" e reforço negativo foi conceituado como "apresentação de consequências indesejáveis", o que conceitualmente seria punição, desde que tais consequências condicionem a diminuição da frequência do comportamento. Ou seja, uma série de equívocos que por fim descaracterizam a teoria abordada ${ }^{51}$ e retiram o potencial explicativo de tal teoria sobre o comportamento humano.

Compreendo que o equívoco no ensino de conteúdos esteja condicionado ao pouco conhecimento da teoria, possivelmente uma dificuldade enfrentada por todos que ministrem psicologia a não psicólogos e tenham de fazê-lo a partir de diferentes temas e autores. Como aponta Carone (2003) a psicologia é uma ciência

51 O objetivo aqui não é analisar essa teoria, assim indico como referências básicas para entender o behaviorismo Skinner $(1970,1982)$ e Baum (1999), as quais o leitor pode se reportar para poder aprofundar os conhecimentos sobre as imprecisões por mim apontadas e sobre a própria teoria. 
muito diversa, na qual coexistem muitas tradições, o que entendo torna difícil conhecer cada corrente teórica com a profundidade necessária para que se possa ensiná-la aos discentes com rigor teórico conceitual e proporcionar a eles a apropriação da teoria sem que sua complexidade seja perdida. Corrobora essa minha hipótese a pesquisa de Dadico (2009), que identificou no campo de uma escola estadual propedêutica os conteúdos psicológicos sendo ministrados com equívocos teóricos. Mesmo no âmbito da graduação e da produção do conhecimento em psicologia, entendo que conseguiríamos nos lembrar de um docente ou um artigo que afirme, por exemplo, que o Behaviorismo Radical "nega ou desconsidera a influência de eventos internos", que a Psicanálise "negligencia os determinantes sociais" ou, no caso do texto utilizado como referência na disciplina observada por Dadico (2009), que apresenta a psicologia como ciência una e discorre sobre "divisões da consciência" em "ego, id e superego" (TELES, $1999^{52}$ apud DADICO, 2009). Afirmações que assim, simplistas, desvinculadas de todo seu corpo de conhecimento, acabam por veicular compreensões equivocadas em relação às teorias psicológicas e demonstram a dificuldade de discorrer com a mesma propriedade sobre cada teoria a partir da vastidão e da diversidade dos conhecimentos psicológicos.

Isto traz dilemas à formação em psicologia, pois se não é possível conhecer todas as teorias em profundidade, nuances e contradições, é preciso ao menos que os processos de formação inicial proporcionem aos futuros docentes o reconhecimento de suas limitações, e que busquem incessantemente superá-las. Como diz Adorno (1995b) em seu texto A filosofia e os professores, ao refletir sobre a crise da formação cultural e as consequências desta para a formação de professores, "É preciso não se conformar com a gravidade da situação e a dificuldade de reagir frente a ela, mas refletir acerca desta fatalidade e as consequências para o próprio trabalho" (p. 73).

Entendo que em algum nível Vinícius sabe de suas limitações ao ensinar conceitos do behaviorismo - pois constantemente olhava para mim em busca de aprovação em relação ao conteúdo desenvolvido e dizia que eu poderia corrigi-lo caso algo estivesse errado, comportamentos não presentes quando Vinícius abordava outros conteúdos. No entanto este saber não o impulsiona a buscar superar suas limitações, mesmo porque essa busca é dificultada em especial por 
sua jornada de trabalho, o trabalho solitário e a inexistência de processos de formação contínua voltados ao ensino de conhecimentos psicológicos pelo Centro Paula Souza.

Outro aspecto do ensino de conteúdos equivocadas é que mesmo quando Vinícius ministra os conteúdos com precisão conceitual - o que ocorria na aula de Psicologia Organizacional, como veremos no item 4.3.2 - ao exemplificá-los por vezes reduzia-os. Por exemplo, ao exemplificar as instâncias de personalidade Vinícius diz: "um funcionário que chega sempre atrasado, não respeita prazos e ordens e faz só aquilo que quer, teria por instância predominante da personalidade o id". Assim, ao exemplificar o conceito apartado de seu arcabouço teórico, faz uso fragmentado e mecanizado da teoria e acaba por naturalizar explicações individualistas, ou seja, individualiza o que está imerso em uma dinâmica social.

Vinícius tenta explicar essa conduta ao afirmar a necessidade de simplificar a linguagem para que os discentes entendam os conteúdos - ou nas palavras do mesmo, é preciso "bater no liquidificador" os conteúdos - e aponta que por vezes nem assim discentes entendem o que está sendo ministrado. Assim como Bohoslavsky (1981), entendo que o professor deve saber que há um papel importante na sua mediação para que discentes possam se apropriar de conteúdos complexos. No entanto, se o docente não deve enfatizar essa distância, também não deve, com o argumento de encurtá-la, apresentar conteúdos de forma equivocada. No caso, a utilização da metáfora do "bater no liquidificador" é reveladora, pois ao "bater-se" algo no liquidificador, o papel outrora ativo de quem se alimentaria é diminuído, pois não precisa se dar o trabalho de "mastigar", no caso, apropriar-se ativamente do conteúdo, já apresentado de forma fragmentada. Entendo que assim as propriedades desse conteúdo perdem importância; as complexidades, as contradições, seu processo histórico, tudo é reduzido a um líquido homogêneo que deve tão somente ser engolido pelos discentes.

No entanto, essa mesma metáfora de Vinícius, embora aponte para uma conduta que subjuga discentes em relação às suas potencialidades de compreensão dos conteúdos, pelos contextos nos quais foi proferida, demonstraram mais uma tentativa de justificar ou mesmo ocultar para mim e para ele próprio sua fragilidade teórica. Como discuti anteriormente, tal fragilidade tem relação com a diversidade dos conhecimentos psicológicos e as poucas possibilidades e estímulos para superá-la, devido à sua carga horária de trabalho e que o esperado dele nas Etecs 
não é o ensino aprofundado de conhecimentos psicológicos, conforme fui apontando nas condições de trabalho e mesmo nas ênfases relegadas ao ensino de psicologia no que se refere à prescrição de formas de ser e agir.

Essa mesma fala, tão recorrente em contextos escolares, me remete a pensar que espaços de formação inicial e contínua precisam proporcionar a reflexão sobre quais conteúdos ensinar e como torná-los compreensíveis aos discentes aos quais se destinam, sem que sua complexidade seja relegada ao segundo plano. No entanto, como visto nas condições de trabalho, não há espaços de formação contínua no âmbito do Centro Paula Souza para docentes da área de psicologia, há escassez de pesquisas e discussões sobre ensino de psicologia na educação profissional (MACIEL, 2009; PIRES, 2009) e a licenciatura em psicologia historicamente foi relegada a um local marginal (MRECH, 2001), o que condiciona o ensino de psicologia a se expressar dessa forma equivocada.

Ainda que atualmente haja iniciativas repensando a licenciatura em psicologia (SEKKEL; MACHADO, 2007; SIMÕES; PAIVA, 2007) as perspectivas de transformação são poucas visto o local complementar relegado à licenciatura nas próprias Diretrizes Curriculares Nacionais para os cursos de Psicologia (CIRINO et al., 2007; LEMOS, 2008; SOLIGO, 2011), e a diminuição do oferecimento de cursos de licenciatura (KOHATSU, 2010; SOLIGO, 2011) ${ }^{53}$.

Entendo que as dificuldades ao trabalho docente aqui elencadas condicionam as expressões de equívocos no ensino de conteúdos, permitindo inferir que as práticas singulares aqui apresentadas se expressem na universalidade do ensino de psicologia nas Etecs.

Considero ainda que o ensino de conteúdos equivocados contribui para a produção de obstáculos na relação do indivíduo com o conhecimento e assim com o gênero, pois ao aprender algo de forma equivocada torna-se mais difícil aprendê-lo corretamente - e as possibilidades emancipatórias dos conhecimentos ficam obscurecidas. Em outras palavras, ao dar-se a falsa impressão de domínio de um conhecimento, aprofunda-se o processo alienante na relação com o gênero, pois estará mediada em bases equivocadas que sequer sabem-se assim.

53 Para repensar tal discussão frente às Diretrizes Curriculares Nacionais para os cursos de graduação em Psicologia publicada em 2011, vide nota de rodapé número 25, na página 46 desta dissertação. 


\subsection{Processos potencialmente emancipatórios: expressões e contribuições do ensino de Psicologia nas Etecs}

Relembrando: foram entendidos como processos potencialmente emancipatórios aqueles que contribuíram para a restituição, ainda que parcial, da posse sobre conhecimentos histórico-socialmente construídos, restituindo parte da relação com o gênero, e os que contribuíram para o estabelecimento de relações em que os homens, especialmente Vinícius e discentes, puderam se relacionar em suas dimensões humanas. A partir do processo de pesquisa pude compreender como contribuindo para processos potencialmente emancipatórios as expressões do ensino de psicologia que envolveram: 1) relações de respeito mútuo; e 2) ensino de conhecimentos histórico-socialmente construídos.

\subsubsection{Relações de respeito mútuo}

De acordo com o Michaelis moderno dicionário da Língua Portuguesa (2004), a palavra "respeito" pode ter diversos significados e a que é consoante à conotação atribuída aqui é "apreço, atenção, consideração" (não paginado). Apresentarei aqui principalmente condutas de respeito de Vinícius para com discentes, e em alguma medida contemplarei também as condutas dos discentes para com Vinícius, entre Etec-Vinícius e Etec-discentes. No entanto, ainda que tenha destacado principalmente questões dos comportamentos de Vinícius, entendo que estes não se expressariam sem o recíproco respeito dos discentes pelo mesmo - por isso os considerei como existência de relações de respeito mútuo.

Ainda que tenha apontado no item 4.3.4 que Vinícius subjugue os discentes em alguns de seus comentários, no relacionamento com os mesmos em sala de aula, em especial na disciplina de Psicologia Organizacional, sua conduta era de respeito e acolhimento aos discentes. Considerei importante destacá-las, pois como aponta Paulo Freire (1996, p. 96), "o respeito que devemos como professores aos educandos dificilmente se cumpre, se não somos tratados com dignidade e decência pela administração privada ou pública de educação".

Um indicativo de conduta que respeita os discentes é o reconhecimento na fala de Vinícius ao dizer que se tornou professor na relação com os discentes, observando-os - "eles me indicaram, ó, continua indo por aqui que tá legal, muda 
isto que não tá legal, indiretamente falando" - e modificando questões relacionadas à postura, à dicção e ao movimentar-se em sala de aula até à necessidade de criar vínculos com os discentes e de apostar na potencialidade dos mesmos.

Penso que essa conduta proporcionou a Vinícius o domínio sobre sua atividade pedagógica no que se refere à entonação de voz, ao uso de gestos e à sinalização verbal e escrita aos discentes das questões que julga mais centrais. Tais comportamentos são consoantes ao que Leite (2006) e Falcin (2006) apontam como comportamentos docentes que facilitam aos discentes a apropriação dos conteúdos e favorecem uma relação afetivamente positiva deles com o conhecimento, possibilitando a apropriação dos mesmos e incentivando-os a quererem conhecer mais.

Essa conduta de respeito também se efetiva na questão da criação de vínculos e na aposta na potencialidade dos discentes, a qual pode ser percebida, por exemplo, na estratégia utilizada por Vinícius de em grande parte da aula dirigir questões aos discentes sobre os conteúdos e utilizar suas respostas para gradualmente construir as corretas, valorizando a participação discente, acreditando no potencial dos mesmos - consequentemente fortalecendo nos discentes um autoconceito positivo e criando uma relação de confiança, na qual discentes podiam expressar suas dúvidas e opiniões. Como afirma Leite (2006, p. 41), posturas como esta, que possibilitam aos jovens experienciarem sucesso nas situações de aprendizagem gradualmente proporcionam a formação de indivíduos afetivamente seguros e melhor preparados para vivenciar as relações com o mundo.

Tais condutas de respeito proporcionam ainda a construção de uma relação de confiança entre Vinícius e os discentes, a qual se fortalece na conduta do primeiro de acolher as dúvidas, ouvindo-as com atenção, com flexibilidade para alterar o rumo da aula a partir das questões dos mesmos sem, no entanto, se distanciar totalmente do tema da aula, motivando assim os discentes a perguntarem mais, a quererem se apropriar mais dos conteúdos ministrados.

Era também nesses momentos de acolher dúvidas que indícios de crítica social podiam ser percebidos. Um exemplo disso ocorreu na aula de Psicologia Organizacional, quando Vinícius explicava os mecanismos de defesa, mais especificamente o deslocamento, e os discentes falaram sobre bullying e os casos nos Estados Unidos da América (EUA) de estudantes que são autores de homicídios em massa, questionando se este seria um tipo de deslocamento. Vinícius não 
responde diretamente, mas pergunta aos discentes se 0 fato de ocorrerem essas situações com tanta frequência nos EUA teria a ver com a cultura do país. Discentes ficam quietos, e Vinícius diz que entende que sim, que não é casual que em uma cultura onde se incentiva tanto a frieza e a competição ocorram situações como essas. Ainda que Vinícius não aprofunde como a frieza e a competição estão presentes na cultura estadunidense, sinaliza que existem determinantes culturais que influem em padrões de comportamento, possibilitando aos discentes olharem para as questões desnaturalizando a culpabilização individual ou mesmo unicamente do grupo diretamente envolvido. Assim, Vinícius se permite abordar em aula questões não planejadas inicialmente e nestas, por vezes, haviam indícios de análises críticas, como a expressada acima.

Contribui ainda para esse ambiente não punitivo e encorajador, assim como para o estabelecimento de relações afetivamente positivas, a postura de Vinícius diante de alguns comportamentos impróprios de discentes durante a aula, como conversar sobre outros assuntos e amassar com os pés latinhas de refrigerante ${ }^{54}$. Vinícius, sem perder a sequência e o contexto da aula ou expor desnecessariamente alguém, pede que se interrompa tal comportamento e continua a ministrar a aula.

Considero que as posturas de respeito aos discentes podem ser inferidas ainda da conduta de Vinícius, proporcionadas por um princípio adotado pela Etec, de partilhar a responsabilidade pelo processo educativo em âmbito escolar nas relações diretas docente-discente e discente-escola. Não observei a responsabilidade por questões em sala de aula transferir-se de Vinícius para a coordenação ou a direção da escola, ou da Etec para os pais. As questões que envolviam dificuldades em relação à disciplina, frequência às aulas ou aproveitamento escolar eram resolvidas em conversas diretas entre os discentes em questão e os responsáveis (Vinícius, no caso de questões pontuais; coordenadores de área no caso de questões que envolvessem o curso). Na reunião de pais (realizada por solicitação destes), isso foi explicitado aos presentes, justificando-se que no curso técnico estão sendo formados profissionais, e por isso os discentes devem assumir suas responsabilidades. Considero que ainda que o discurso que justifique a conduta de Vinícius e da Etec seja a produção de uma conduta profissional adequada ao ambiente de trabalho, proporciona-se aos discentes autonomia para decidirem sobre

54 A discente o fazia para facilitar o transporte, pois venderia as latinhas para poder financiar parte dos custos envolvidos no projeto de conclusão de curso. 
a condução de sua vida escolar, o que penso se refletir na reciprocidade do respeito dos discentes para com Vinícius e Etec.

Entendo que as condutas de respeito de Vinícius para com discentes é proporcionada pelo espaço de autonomia que ainda lhe resta em relação às formas de ministrar aula, o qual pode ser percebido pela postura da coordenadora em possibilitar aos docentes a escolha sobre se me receberiam ou não em suas salas de aula.

É importante destacar que esses comportamentos que considerei como respeitosos com os discentes ocorrem marginalmente nas aulas de Psicologia Social e são predominantes nas aulas de Psicologia Organizacional. Entendo que sua presença marginal nas aulas de Psicologia Social relaciona-se ao que analisei quanto às diversas formas de alienação na atividade docente e às condições de trabalho específicas a esta disciplina, em especial a restrição dos temas a serem ministrados, a pressão pela empregabilidade dos discentes, o próprio maior estranhamento de Vinícius nesta disciplina e a progressiva diminuição da motivação dos discentes dada a ênfase nas prescrições de formas de ser e agir.

Se a conduta de Vinícius é diferenciada - penso condicionada especialmente por sua possibilidade de ministrar conteúdos mais gerais na disciplina de Psicologia Organizacional e pela menor pressão neste momento do curso quanto à empregabilidade dos discentes -, a postura dos discentes também o é, e nas aulas dessa disciplina discentes estão na maior parte do tempo empenhados nas atividades e verbalizam frequentemente o quanto gostam da aula, que o dia dela é o dia em que não faltam à escola.

No entanto, ainda que o espaço de autonomia dentro da sala de aula e as condições de trabalho específicas para cada disciplina influam nas relações de respeito exemplificadas, entendo que tais fatores não me permitem afirmar a universalidade de sua existência no ensino de psicologia das Etecs, ainda que me permitam inferir que há espaços diferenciados para que ocorram.

Compreendo que com relação ao respeito aos discentes o papel da singularidade de Vinícius mereça destaque. Entender o que em suas experiências singulares contribuiu para tal conduta seria importante para possibilitar uma análise mais próxima à universalidade e para refletir se e como a licenciatura em psicologia poderia colaborar para que os docentes mantivessem essa conduta de respeito. Porém, embora considere as condutas de Vinícius para com os discentes 
importantes, penso que o respeito não se restringe a elas, mas envolve também a necessidade de preparação das aulas; busca incessante pelo aperfeiçoamento na formação; e postura de desconfiança, questionamento crítico e subversão em relação aos temas impostos, transformando-os em conteúdos críticos. Enfim, é preciso que o respeito devido aos discentes se concretize também nessas dimensões e é preciso pensar como a licenciatura em Psicologia poderia contribuir para tal.

Enfatizo que, ainda que aponte necessidades de avanço, as relações de respeito entre Vinícius e discentes proporcionam um ambiente no qual se formam indivíduos afetivamente seguros e motivados a aprenderem os conteúdos (FALCIN, 2006; LEITE, 2006), o que se tornava potencialmente emancipatório quando conhecimentos histórico-socialmente construídos eram ministrados.

Essas mesmas relações de respeito facilitavam ainda a criação de um ambiente em que Vinícius e discentes podiam se expressar, o que favoreceria a discussão e reflexão crítica, a qual porém não pode se concretizar, pois, como veremos, os conteúdos ensinados não eram vinculados a análises sociais.

Mesmo assim, considero que as relações de respeito mútuo destacadas ao longo deste item proporcionaram a Vinícius e aos discentes a experiência de uma relação na qual se defrontaram com o outro em suas dimensões humanas, e não como um meio de produção, pois nestes momentos não era a vinculação dos conteúdos a uma utilidade imediata ou a obtenção de vantagem individual que estava em foco, mas sim a relação entre Vinícius e discentes e destes com os conhecimentos - o que entendo como potencialmente emancipatório.

\subsubsection{Ensino de conhecimentos histórico-socialmente construídos}

Entendi como ensino de conhecimentos histórico-socialmente construídos os momentos nos quais foram ensinados conhecimentos clássicos ${ }^{55}$, com precisão conceitual, apresentando discordâncias entre teorias e diferentes métodos de construção do conhecimento psicológico.

55 Para Saviani e Duarte (2010), clássicos são "formulações [que] embora radicadas numa época determinada, extrapolam os limites dessa época, mantendo seu interesse mesmo para as épocas posteriores" (p. 431). 
Como apontei anteriormente, há uma grande restrição aos temas possíveis de serem abordados na disciplina de Psicologia Social. Considero que isso condicionou a inexistência do ensino de conhecimentos histórico-socialmente construídos nas aulas observadas desta disciplina, ainda que compreenda que as brechas proporcionadas pelo espaço de autonomia em sala de aula possibilitariam que os mesmos temas pudessem ser ensinados de forma contextualizada, histórica e crítica, como apontarei nas considerações finais.

Penso que as condições de trabalho específicas da disciplina de Psicologia Organizacional - em especial a amplitude mais geral de seus conteúdos - se refletiram em parte no ensino de conteúdos marginais, equivocados e em prescrições de formas de ser e agir, conforme já analisado, e em menor proporção no ensino de conhecimentos histórico-socialmente construídos, como exemplifico a seguir.

Abordei anteriormente a utilização do recurso de um mesmo filme sobre trabalho nas duas disciplinas e a forma como foi apresentado na aula de Psicologia Social. Em contraste, na disciplina de Psicologia Organizacional o vídeo foi apresentado na íntegra e versava sobre o processo de desenvolvimento histórico do trabalho no mundo e no Brasil. Apresentava as formas como as relações entre os homens, e destes com o trabalho, modificaram-se historicamente, produzindo e acentuando desigualdades, relacionando esse desenvolvimento às questões de divisão social de classes, relacionamento entre nações, atividades produtivas e clima político de cada época, formas de organização do trabalho e lutas sociais. Ou seja, nessa aula, o conceito de trabalho foi apresentado de forma problematizada, histórica e crítica, possibilitando aos discentes conhecerem o tema, o que considero como potencialmente emancipatório, ainda que explorado de forma incipiente por Vinícius, que não discute o filme com a classe.

No exercício em grupo que seguiu ao filme, Vinícius solicitou entre outras questões que discentes respondessem se o trabalho traria satisfação, em quais condições isso seria possível e a diferença entre trabalho motivador e mecanizado. O filme não abordava explicitamente tais aspectos da formação subjetiva do trabalhador, as quais tampouco foram abordadas por Vinícius, assim, os aspectos mais diretamente relacionados à psicologia não foram ensinados e não puderam ser refletidos. A ausência da mediação de Vinícius possibilitou que concepções alienadas dos discentes acerca dos processos de subjetivação humana no trabalho 
não fossem questionadas, como pude ver nas respostas de um dos grupos de discentes, que vincularam satisfação e motivação unicamente a uma boa retribuição financeira, subordinando as dimensões próprias das condições de trabalho ao contexto social que atribui valor e conforma identidades a partir do poder de consumo (CORRÊA, 2006). Assim, ainda que discentes reconheçam esse contexto social, não se proporcionou que o questionassem e não o assumissem como natural.

Penso que o ensino de conhecimentos histórico-socialmente construídos foi proporcionado quando Vinícius tratou com rigor conceitual a questão da personalidade para Freud e seu funcionamento na relação entre as instâncias psíquicas id (regido pelo princípio do prazer, demandando satisfação imediata dos desejos e necessidades), ego (regido pelo princípio de realidade, media as relações entre id e superego) e superego (princípios morais, internalizados na relação com os outros, com os pais, na educação, com a cultura e o que esta considera certo ou errado em um dado momento histórico), ainda que, ao exemplificá-los, Vinícius o tenha feito de forma equivocada como apresentei e analisei no item 4.3.4.

Em alguns momentos da disciplina Psicologia Organizacional, Vinícius proporcionou o conhecimento da existência de autores como Freud e Skinner, falou do processo de como cada autor desenvolveu suas teorias e mostrou a diversidade dos métodos utilizados por cada autor. Apontou assim que na psicologia há diferentes explicações para um mesmo fenômeno, que podem ser construídas por métodos diferentes. Expôs ainda que um mesmo autor repensa suas explicações, como no caso de Freud e as mudanças entre a primeira e a segunda tópica. Ou que outros autores repensam teorias, como foi realizado no seminário sobre motivação, onde discentes apresentaram a pirâmide das necessidades de Abraham Maslow e as críticas à mesma de Victor Frankl e Henry Murray. Ao explicitar diferentes explicações, diferentes métodos e mudanças na teoria, penso que Vinícius apresenta a psicologia como ciência diversa que é, e que mesmo dentro da ciência é possível diferentes formas de conhecer e explicar um mesmo fenômeno. Considero que isso se aproxima de uma das dimensões defendidas na proposta do Conselho Regional de Psicologia, 6ำ região (1986), a de não se conferir uma unidade artificial a uma ciência constituída pela diversidade, proporcionando aos discentes uma aproximação a complexidade da Psicologia. 
Considero que os exemplos destacados demonstram possibilidades encontradas de que conhecimentos histórico-socialmente construídos possam ser ensinados no campo das Etecs, em especial em disciplinas e cursos que prevejam temas mais gerais não tão subordinados à aplicabilidade dos conteúdos e a uma ênfase na empregabilidade de seus concluintes. Assim, esses exemplos evidenciam brechas encontradas em um processo contraditório, que, como vimos no capítulo sobre educação profissional, ao pregar um novo tipo de trabalhador ao mesmo tempo em que enfatiza as dimensões subjetivas em uma perspectiva individualista, requer a veiculação de saberes acadêmicos e princípios de formação geral em uma educação historicamente instrumental.

Embasada nessas considerações é que compreendo que o ensino de conhecimentos histórico-socialmente construídos, encontrados na realidade singular da Etec campo desta pesquisa, sinalize sua possibilidade de universalidade no âmbito da disciplina de Psicologia Organizacional no curso de técnico em Administração das Etecs.

Cabe ponderar que, ainda que tais conhecimentos sejam ensinados, estão muito distantes de considerar a dimensão histórica e proporcionar sua análise crítica. Assim não se aproximam das propostas de Saviani (2000) e estão ainda mais distantes de ter como objetivo a construção de uma realidade qualitativamente diferente, conforme propõe Tonet (2007). Os conhecimentos ensinados tampouco possibilitam a compreensão das condições sociais geradoras de conflito, conforme propõe Leite (2007), e não auxiliam os discentes na compreensão de disposições subjetivas internalizadas pelos sujeitos frente à barbárie, conforme proposta de Barros (2007), pois não se dedicam a desvendar questões de ordem social, não possibilitando compreensões sobre as determinações sociais.

No entanto, ainda que essas dimensões não sejam abordadas e que os conhecimentos ensinados não tenham o objetivo intencional de favorecimento da constituição de indivíduos críticos e mesmo que limitados pelas exemplificações equivocadas, entendo que o ensino dos conhecimentos histórico-socialmente construídos possibilitou a relação dos discentes com o gênero humano a partir de algumas de suas objetivações e por isso os considerei como processos potencialmente emancipatórios. 


\section{CONSIDERAÇÕES FINAIS}

Nesta dissertação, para conhecer as contribuições do ensino de psicologia nas Etecs, busquei na história da educação profissional e do ensino de psicologia elementos que me auxiliassem a desvendar este campo.

Deparei-me com um sistema de ensino, especialmente no nível médio, historicamente vinculado a interesses privados e comprometido em atender as demandas de mão de obra necessária ao mercado de trabalho em cada época e em cada setor produtivo. Tal "subordinação ativa e consentida à lógica do mercado" (FRIGOTTO; CIAVATTA, 2003) se concretiza no âmbito das Etecs em uma naturalização do distanciamento das finalidades de formação humana crítica e no resgate de dimensões da subjetividade do trabalhador, enfatizando o saber ser "adaptável, flexível, competitivo, dinâmico". Dessa forma se valorizam características individuais em detrimento de características formativas e saberes acadêmicos que um dado curso poderia prover, buscando justificar e direcionar o indivíduo à aceitação das condições do trabalho estranhado e à internalização da responsabilidade por um futuro desemprego.

Porém, quanto a como e porque o ensino de psicologia se insere nas Etecs, pouco podia ser compreendido tendo em vista a escassez de pesquisas e reflexões sobre o ensino de psicologia na educação profissional. Isso revela a necessidade de mais pesquisas sobre o tema, tanto em suas dimensões históricas como atuais, abrangendo o território nacional e os diferentes cursos nos quais está inserido. Considero este um desafio a ser assumido pela categoria profissional da psicologia, promovida seja pelos pesquisadores que se dedicaram ao tema, pelos envolvidos com os cursos de licenciatura em todo o país e pelas entidades organizativas da categoria, especialmente pela ABEP, que é a entidade dos profissionais de psicologia diretamente vinculada ao tema.

A presente pesquisa foi uma iniciativa nessa direção e desvelou um amplo campo de atuação possível para o licenciado em Psicologia nas Etecs, vislumbrando que o ensino de conhecimentos psicológicos está previsto para uma grande variedade de cursos, influindo na formação de um grande número de discentes, o que me incitou a querer conhecer quais suas contribuições.

Para tal realizei pesquisa de campo em uma Etec e intenso trabalho teórico, a partir dos quais pude conhecer e discutir diferentes expressões e contribuições do 
ensino de psicologia nas mesmas, revelando em um quadro geral o predomínio de processos potencialmente alienantes e escassez de processos potencialmente emancipatórios no ensino de psicologia, condicionado profundamente pelas condições de trabalho impostas aos docentes nas Etecs. Aos desvelar esses condicionantes considero que é possível afirmar que as expressões do ensino de psicologia aqui discutidas se façam presentes, em maior ou menor grau, na ampla variedade de disciplinas e cursos existentes nas Etecs.

Como fui apontando nas análises expostas, considero que tais expressões do ensino de psicologia contribuam para o aprofundamento de processos alienantes e reforcem discursos da ideologia dominante, buscando que os discentes a mesma se conformem. Porém, o que esses discursos efetivamente produzem nos discentes é difícil saber. Os discentes aderem e se conformam? Ou desconfiam e resistem? O que esses discursos produzem nos discentes estaria relacionado às expectativas dos mesmos em relação ao curso técnico? Quais são as expectativas dos discentes em relação ao curso técnico? Discentes buscam o ensino técnico crendo no mito do emprego certo? Buscam uma atividade extracurricular? Buscam uma ponte para o ensino superior? Tais expectativas são diferentes para cursos distintos? As expectativas dos discentes estão relacionadas a seu perfil de faixa etária, formação prévia, condição socioeconômica? Como vimos na caracterização dos discentes há algumas diferenças em relação ao perfil dos discentes do período diurno e noturno. Será que existem outras diferenças em relação ao perfil dos discentes e mesmo de suas expectativas quando tomamos como referência os períodos de estudo diurno e noturno? Talvez todas essas questões se relacionem, e considero-as como possíveis desdobramentos desta pesquisa, tendo como foco o que discentes aprendem e quais os efeitos subjetivos do ensino de psicologia nas Etecs.

No entanto, no que se refere ao ensino de psicologia, penso que pela pesquisa ora desenvolvida é possível dizer que ainda que este não produza efetivamente conformação dos discentes às demandas ideológicas do mercado, também não discute conhecimentos que sustentem suas possíveis dúvidas e possibilitem reflexão. Em outras palavras, mesmo que discentes por inúmeras questões acabem questionando o que é ensinado, os conteúdos ministrados nas aulas de psicologia não os auxiliam na elaboração teórica, radicalização dos questionamentos e contraposição ao discurso hegemônico nas Etecs e na sociedade. 
Penso que para se produzir outro ensino de psicologia nas Etecs é preciso questionar a naturalização de que no espaço da educação técnica não há porque existir finalidades de formação crítica. Esse questionamento ultrapassa a mera denúncia da subordinação das Etecs a uma secretaria outra que não a da Educação. Envolve o desvelar do porque a Secretaria da Educação gradativamente se desresponsabilizou das Etecs e do porque a organização delas por vezes parece oferecer condições de trabalho diferenciadas (como vimos na caracterização da Etec e nas condições de trabalho). Envolve ainda reconhecer que os limites a serem ultrapassados nas Etecs foram construídos na história da educação profissional e o quanto prevaleceram os interesses privados, do mercado de trabalho e a vinculação entre demandas do setor produtivo e "competências e habilidades" a serem providas pela educação.

Outra questão urgente é a luta por outras condições de trabalho, com boa remuneração, horas remuneradas de estudo, processos de formação contínua e especialmente respeito à autonomia docente, envolvendo o debate e a construção de referências para os cursos técnicos não subordinadas às demandas do mercado de trabalho, mas que tenham como objetivo primeiro o resgate da formação humana crítica. Tais referências precisam ser discutidas com a comunidade escolar, direção, coordenadores, docentes e discentes de cada curso, sem negligenciar as realidades de cada profissão, mas não meramente adequando-se a elas.

No que se refere ao ensino de conhecimentos psicológicos, penso ainda que a categoria profissional da psicologia não pode se furtar ao diálogo para a construção dessas referências, a fim de contribuir para que conhecimentos críticos da Psicologia sejam ensinados.

Ainda que saiba que a luta pela transformação das Etecs e das condições de trabalho nas mesmas existentes seja difícil - pois como vimos pela história da educação profissional há condições concretas de existência e interesses que a tal transformação se opõem - que ela ao menos produza fissuras, desvele contradições, resista a tantas imposições.

Porém, reconhecer os limites que condicionam o ensino de Psicologia nas Etecs e lutar pela transformação dos mesmos não é a única frente necessária de atuação. Pois, ainda que existam mecanismos institucionais que limitam as possibilidades do ensino de psicologia nas Etecs, a ideologia não é tão uniforme e o controle não é total. As brechas podem ser percebidas pela existência, no Centro 
Paula Souza, de Planos de Curso com restrições, ênfases e possibilidades distintas, como vimos ao comparar os Planos de Curso de técnico em Administração e em Marketing. E mesmo diante das restrições específicas de cada Plano de Curso considero ser possível que o ensino de psicologia contribua mais significativamente para a emancipação dos discentes, aproveitando os espaços de autonomia docente dentro de sua sala de aula.

Assim, no que se refere à disciplina de Psicologia Social a pesquisa revelou grandes limitações ao potencial emancipatório e o predomínio de processos potencialmente alienantes, em grande parte vinculados à restrição dos temas a serem abordados, subordinados às competências, fossem estas técnicas ou de formas de ser e agir, tudo isso relacionado ainda ao apelo à empregabilidade. Penso que ainda que as determinações desvendadas se façam presentes - e se fazem, e são potentes -, uma maneira de construir caminhos para superá-las seria construir junto aos atuais e futuros docentes de disciplinas com tais características uma atitude de distanciamento em relação ao que está prescrito, às normas, e ao que é esperado da educação profissional. Ao analisar tais questões criticamente e não se limitar a elas, aproveitando o espaço de autonomia em sala de aula, os docentes poderiam, por exemplo, ensinar temas como recrutamento, seleção, treinamento e desenvolvimento sem negligenciar suas dimensões históricas, apontando porque tais processos são presentes e enfatizados na sociedade atual, porque e quais tipos de trabalhador têm sido desejados e quais os efeitos subjetivos desses processos nos trabalhadores. Penso que ao fazê-lo não é preciso negligenciar a dimensão de aplicação da técnica requerida ao exercício da função para a qual os discentes são formados, apenas não se limitar a ela e recusar-se a prescrever formas de ser a agir. Conhecimentos críticos produzidos na área de Psicologia Social e do Trabalho, por exemplo, poderiam ser discutidos, e entendo que seriam potencialmente emancipatórios. E como apontei a escassez de conhecimentos que se voltem à educação técnica, poderiam ser buscadas parcerias com docentes de orientação crítica que ministrem esses conteúdos no Ensino Superior, talvez nos próprios cursos superiores de Administração e Marketing, como uma primeira imersão na construção de um currículo nesse sentido.

Em relação à disciplina de Psicologia Organizacional, considero que os processos desvelados, ainda que apontem o predomínio de processos potencialmente alienantes, demonstram contribuições, ainda que incipientes, do 
ensino de psicologia para processos potencialmente emancipatórios. Cabe lembrar que a disciplina pertence ao curso de técnico em Administração, que conforme vimos está presente em $79 \%$ das Etecs, e tem o maior número de discentes matriculados, ou seja, há potencial para o ensino de psicologia, este é oferecido a grande número de discentes e precisa ser refletido para se tornar mais crítico e emancipatório.

Nessa disciplina, no que se refere ao ensino de conhecimentos históricosocialmente construídos, as mesmas teorias e temas ensinados - no caso personalidade, comportamento e trabalho - poderiam possibilitar análises críticas se direcionados a análises do processo de subjetivação humana frente às condições de trabalho e existência atuais. Dessa forma, poderiam sim contribuir para processos potencialmente emancipatórios e, porque não, direcionarem-se à necessidade de construção de outra sociedade. Os mesmos autores trabalhados em sala de aula, como Freud e Skinner, possuem produções nesse sentido, e há ainda desdobramentos atuais de suas teorias que auxiliariam na compreensão de que subjetividades são produzidas na sociedade atual. Penso ainda que a inclusão de conhecimentos da Psicologia Histórico-Cultural e da Teoria Crítica da Sociedade também auxiliariam neste processo. Aqui também a construção de diálogos, parcerias, seria importante para efetivamente estabelecer um ensino de psicologia mais crítico. Dada a característica de introdução à psicologia dessa disciplina, penso que o debate com os professores e pesquisadores que têm se debruçado sobre 0 ensino de psicologia no nível médio propedêutico poderia dar início a esse processo.

Assim, pequenas subversões, mesmo considerando as limitações presentes no contexto de trabalho das Etecs, penso que sejam possíveis. Sem, é claro, deixar de lado a luta por outras condições de trabalho e pela transformação dos objetivos do ensino técnico.

Para que as subversões aqui apontadas ocorram, penso que o desafio maior é cuidar da formação do professor de psicologia. Afirmo isso porque ainda que haja escassez de discussão sobre o ensino de psicologia na educação técnica, creio que acima aponto caminhos para o início dessa superação, nos quais a construção de parcerias tem papel de destaque bem como a necessidade de que a categoria de profissionais da psicologia assuma a sua parcela de responsabilidade e dedique-se a estudar, debater e construir outro ensino de psicologia nas escolas técnicas. 
No entanto, considero que nada do que foi aqui pontuado seja possível de realizar sem que haja o devido cuidado em relação à formação dos docentes de psicologia. Tal cuidado envolve o reconhecimento da especificidade da licenciatura e a importância de sua articulação com a formação de psicólogos. A licenciatura continuar a ocupar um lugar marginal e complementar é algo que, no meu entender, nega e se opõe à importância da formação de profissionais que terão como função formar muitos outros jovens e adultos, como é o caso de professores de psicologia no nível médio, seja ele propedêutico ou profissional.

Ao longo da discussão fui apontando vários desafios em relação à formação desses professores. Penso que o destaque a ser dado aqui deva dizer respeito à necessidade de se pensar como a licenciatura em Psicologia poderia contribuir para formar docentes que construam um ensino de psicologia potencialmente emancipatório em suas salas de aula nos cursos técnicos.

A partir da pesquisa, penso que uma das contribuições da licenciatura seria proporcionar a ciência das dificuldades inerentes ao seu campo de conhecimento, da insuficiência da sua formação inicial para poder ensinar diferentes teorias, temas e autores para estudantes de nível médio. Adorno (1995b) aponta que ao futuro professor deve ser proporcionado conhecer o peso da sua responsabilidade na formação de seus discentes, e que este o leve a buscar aperfeiçoamento constante a fim de não perpetuar em seus discentes as deficiências de sua própria formação.

Considero como outra contribuição necessária da licenciatura proporcionar aos futuros docentes: o conhecimento do campo da educação profissional e dos limites que encontrarão na prática profissional no mesmo; um distanciamento crítico desses limites e a descoberta das brechas nas quais seria possível efetivar práticas potencialmente emancipatórias. No entanto, como preservar tal questionamento crítico em condições de trabalho tão hostis?

Penso que se tiver sido proporcionado que docentes mantenham a busca pelo aprimoramento contínuo e uma postura crítica frente a seu contexto de trabalho, estas os manterão construindo parcerias, debatendo práticas, distanciando-se de suas condições de trabalho e assim não subsumindo as mesmas.

Porém, é isto que se tem produzido nas licenciaturas em Psicologia? E como se constituirão as novas licenciaturas caso efetivamente se concretize o previsto nas Diretrizes Curriculares Nacionais para os cursos de graduação em Psicologia 
(BRASIL, 2011), que estabelece que todos os cursos de graduação ofereçam essa habilitação como opção a seus discentes?

Enfim, essas são questões para uma futura pesquisa. No que diz respeito à pesquisa desenvolvida, sintetizo que a mesma permite entrever as potencialidades e limites do ensino de psicologia no campo das Etecs, afirmando a possibilidade deste contribuir para a formação humana emancipada, desde que: a) considere criticamente os condicionantes inerentes ao seu próprio campo de conhecimento e formação de seus professores bem como a modalidade educacional na qual está inserido $e$ as condições de trabalho docente nas Etecs; e b) busque incessantemente superá-los, construindo tanto internamente, na categoria de profissionais da psicologia, quanto no diálogo com educadores e sociedade possibilidades de uma educação profissional e do ensino de psicologia na mesma, que seja emancipatório. Para tal, aponto como necessárias lutas no sentido da modificação de políticas públicas de educação e transformações na formação inicial e contínua dos professores de psicologia. 


\section{REFERÊNCIAS ${ }^{56}$}

ADORNO, Theodor W. Teoria de la seudocultura. In: supersticion. Madrid: Alianza Editorial, 1972. p. 141-174. Filosofia y supersticion. Madid: Alanza Editoilal, 1972. p. 141-174. Educação - para quê? In: Janeiro: Paz e Terra, 1995a. p. 139-154. Educação e emancipação. Rio de A filosofia e os professores In: Janeiro: Paz e Terra, 1995b. p. 51-74. Educação e emancipação. Rio de

AMARAL, Ligia Assumpção. Resgatando o passado: deficiência como figura e vida como fundo. São Paulo: Casa do Psicólogo, 2004.

ANDERSON, Perry. Considerações sobre o marxismo ocidental: nas trilhas do materialismo histórico. São Paulo: Boitempo Editorial, 2004.

ANTUNES, Mitsuko Aparecida Makino. A Psicologia no Brasil: leitura histórica sobre sua constituição. São Paulo: Unimarco, 1998.

ARAÚJO, Almério Melquíades de. Mudanças curriculares no ensino técnico de São Paulo. In: Estudos Avançados, vol. 15, noㄴ 42, p. 209-216, maio-ago. 2001.

BARROS, Carlos César. Reflexões sobre a formação de professores de psicologia. In: Temas em Psicologia, vol. 15, no 1, p. 33-39, 2007.

Fundamentos filosóficos e políticos da inclusão escolar: um estudo sobre a subjetividade docente. 260f. Tese (Doutorado em Psicologia) - Instituto de Psicologia, Universidade de São Paulo, 2009.

BAUDELOT, Christian; ESTABLET, Roger. L’École capitaliste en France. Paris: François Maspero, 1971.

BAUM, Willian M. Compreender o behaviorismo: ciência, comportamento e cultura. Porto Alegre: Artes Médicas, 1999.

BECKER, Howard S. Sobre metodologia. In: Métodos de pesquisa em

56 De acordo com a ASSOCIAÇÃO BRASILEIRA DE NORMAS TÉCNICAS. NBR 6023. 
ciências sociais. São Paulo: Hucitec, 1999, p. 17-46.

BOGDAN, Robert; BIKLEN, Sari. Investigação qualitativa em Educação. Portugal: Porto Editora, 1994. p. 19-51.

BOHOSLAVSKY, Rodolfo H. A psicopatologia do vínculo professor - aluno: o professor como agente socializante. In: PATTO, Maria Helena Sousa (org.). Introdução à psicologia escolar. São Paulo: T. A. Queiroz, 1981. p. 320-341.

BRASIL. Decreto no 7.566 de 23 de setembro de 1909. Créa nas capitaes do Estados da Escolas de Aprendizes Artífices, para o ensino profissional primário. Disponível em: <http://portal.mec.gov.br/setec/arquivos/pdf3/decreto_7566_1909. pdf $>$. Acesso em 23 abr. 2010.

Decreto no 19.560 de 5 de janeiro de 1931. Aprova o regulamento que organiza a Secretaria de Estado do Ministério da Educação e Saúde Pública. Disponível em: <http://portal.mec.gov.br/arquivos/pdf/d19560.pdf>. Acesso em 23 abr. 2010.

. Decreto no 21.241 de 4 de abril de 1932. Consolida as disposições do ensino secundário e dá outras providências. Disponível em: <http://www.histedbr. fae.unicamp.br/navegando/fontes_escritas/5_Gov_Vargas/decreto\%2021.2411932\%20reforma\%20francisco\%20campos.htm>. Acesso em 23 abr. 2010.

Decreto no 24.558 de 3 de março de 1934. Transforma a Inspetoria do Ensino Profissional em Superintendência do Ensino Industrial, e dá outras providências. Disponível em: <www2.camara.gov.br/legin/fed/decret/1930-1939/ decreto-24558-3-julho-1934-515808-norma-pe.html>. Acesso em 23 abr. 2010.

Constituição dos Estados Unidos do Brasil (de 10 de novembro de 1937). 1937. Disponível em <https://www.planalto.gov.br/ccivil_03/Constituicao/ Constituiçao37.htm>. Acesso em 23 abr. 2010.

Decreto no 6.029 de 26 de julho de 1940. Aprova o regulamento para instalação e funcionamento dos cursos profissionais que cogita 0 art. $4^{\circ}$ do DecretoLei no 1238, de 2 de maio de 1939. Disponível em: <http://www2.camara.gov.br/ legin/fed/decret/1940-1949/decreto-6029-26-julho-1940-324447-publicacaooriginal1-pe.html>. Acesso em 23 abr. 2010.

Decreto-Lei no 4.048 de 22 de janeiro de 1942. Cria o Serviço Nacional de Aprendizagem Industrial. 1942a. Disponível em: <http://www.planalto.gov.br/ 
ccivil_03/Decreto-Lei/1937-1946/Del4048.htm >. Acesso em 23 abr. 2010.

Decreto-Lei no 4073, de 30 de janeiro de 1942. Lei Orgânica do Ensino Industrial. 1942b. Disponível em: <http://www.planalto.gov.br/ccivil_03/DecretoLei/1937-1946/Del4073.htm>. Acesso em 23 abr. 2010.

Decreto-Lei no 6.142 de 28 de dezembro de 1943. Lei Orgânica do Ensino Comercial. Disponível em: <http://www.histedbr.fae.unicamp.br/navegando/fontes_ escritas/5_Gov_Vargas/lei\%20organica\%20ensino\%20comercial\%201943.htm>. Acesso em 23 abr. 2010.

Decreto-Lei no 8.530 de 2 de janeiro de 1946. Lei Orgânica do Ensino Comercial. 1946a. Disponível em: <http://www.histedbr.fae.unicamp.br/navegando/ fontes_escritas/6_Nacional_Desenvolvimento/decreto-lei\%20n.\%208.530\%20-\%20 de\%202\%20de\%20janeiro\%20de\%201946\%20\%20lei\%20organica\%20ensino\%20 normal.htm>. Acesso em 23 abr. 2010.

Decreto-Lei no 9.613 de 20 de agosto de 1946. Lei Orgânica do Ensino Agrícola. 1946b. Disponível em: <http://www.planalto.gov.br/ccivil_03/DecretoLei/1937-1946/Del9613.htm>. Acesso em 23 abr. 2010.

. Lei no 1.076 de 31 de março de 1950. Assegura aos estudantes que concluírem curso de primeiro ciclo do ensino comercial, industrial ou agrícola, o direito à matrícula nos curso clássico e científico e dá outras providências. Disponível em: <http://www2.camara.gov.br/legin/fed/lei/1950-1959/lei-1076-31marco-1950-363480-publicacaooriginal-1-pl.html>. Acesso em 23 abr. 2010.

Lei no $\mathbf{1 . 8 2 1}$ de 12 de março de 1953. Dispõe sobre o regimento de equivalência entre diversos cursos de graus médio para efeito de matrícula no ciclo colegial e nos cursos superiores. Disponível em: <http://www2.camara.gov.br/legin/ fed/lei/1950-1959/lei-1821-12-marco-1953-366631-publicacaooriginal-1-pl.html>. Acesso em 23 abr. 2010.

Decreto no 50.945 de 13 de julho de 1961. Permite aos portadores do curso colegial matrícula na 3aㅗ série dos cursos industriais técnicos. Disponível em: <http://www2.camara.gov.br/legin/fed/decret/1960-1969/decreto-50945-13-julho1961-390543-publicacaooriginal-1-pe.html>. Acesso em 23 abr. 2010.

Lei no 5.540 de 28 de novembro de 1968. Fixa as normas de organização e funcionamento do ensino superior e sua articulação com a escola média, e dá outras providências. Disponível em: <http://www.planalto.gov.br/ccivil_03/Leis/ L5540.htm>. Acesso em 23 abr. 2010. 
. Lei no 5.692 de 11 de agosto de 1971. Fixa as diretrizes e bases para o ensino de $1^{\circ}$ e $2^{\circ}$ graus, e dá outras providências. Disponível em: <http://www. planalto.gov.br/ccivil_03/Leis/L5692.htm>. Acesso em 23 abr. 2010.

. Lei no 7.044 de 11 de agosto de 1982. Altera dispositivos da Lei no 5692, de 11 de agosto de 1971, referentes à profissionalização do ensino de $2^{\circ}$ grau. Disponível em: <http://www.planalto.gov.br/ccivil_03/Leis/L7044.htm>. Acesso em 23 abr. 2010.

. Constituição da República Federativa do Brasil de 1988. Disponível em: <http://www.planalto.gov.br/ccivil_03/Constituicao/Constituicao.htm>. Acesso em 23 abr. 2010.

. Lei no 9.394, de 20 de dezembro de 1996. Estabelece as diretrizes e bases da educação nacional. Disponível em:

<https://www.planalto.gov.br/ccivil_03/Leis/_L9394.htm>. Acesso em 23 abr. 2010.

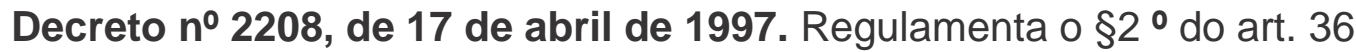
e os arts. 39 a 42 da Lei o 9.394, de 20 de dezembro de 1996, que estabelece as diretrizes e bases da educação nacional.1997. Disponível em: <http://www.planalto. gov.br/ccivil_03/decreto/D2208.htm>. Acesso em 29 jan. 2011.

Resolução CNE/CEB no 4, de 8 de dezembro de 1999. Institui as Diretrizes Curriculares Nacionais para a Educação Profissional de Nível Técnico. Disponível em: <http://portal.mec.gov.br/dmdocuments/rceb004_99.pdf>. Acesso em 23 abr. 2010.

. Parâmetros Curriculares Nacionais (Ensino Médio). Bases legais. 2000. Disponível em: <http://portal.mec.gov.br/seb/arquivos/pdf/blegais.pdf $>$. Acesso em: 10 mar. 2010.

Resolução CNE/CP no 1, de 18 de fevereiro de 2002. Institui Diretrizes Curriculares Nacionais para a formação de professores da Educação Básica, em nível superior, curso de licenciatura, de graduação plena. 2002a. Disponível em: <http://portal.mec.gov.br/cne/arquivos/pdf/CP012002.pdf>. Acesso em 05 nov. 2010.

Resolução CNE/CP no 2, de 18 de fevereiro de 2002. Institui a duração e carga horária dos cursos de licenciatura, de graduação plena, de formação de professores da Educação Básica em nível superior. 2002b. Disponível em: <http:// portal.mec.gov.br/cne/arquivos/pdf/CP022002.pdf>. Acesso em 05 nov. 2010. 
Decreto no 5.154 de 23 de julho de 2004. Regulamenta o $\S 2^{\circ}$ do art.

36 e os arts. 39 a 41 da Lei no 9394, de 20 de dezembro de 1996, que estabelece as diretrizes e bases da educação nacional, e dá outras providências. 2004a.

Disponível em: <https://www.planalto.gov.br/ccivil_03/_Ato2004-2006/2004/Decreto/

D5154.htm>. Acesso em 23 abr. 2010.

Resolução CNE/CES no 8, de 7 de maio de 2004. Institui as Diretrizes Curriculares Nacionais para os cursos de graduação em Psicologia. 2004b. Disponível em: <http://portal.mec.gov.br/cne/arquivos/pdf/rces08_04.pdf>. Acesso em 05 nov. 2010.

. Lei no 11741, de 16 de julho de 2008. Altera os dispositivos da Lei no 9394, de 20 de dezembro de 1996, que estabelece as diretrizes e bases da educação nacional, para redimensionar, institucionalizar e integrar as ações da educação profissional de nível médio, da educação de jovens e adultos e da educação profissional tecnológica. 2008a. Disponível em: <https://www.planalto.gov.br/ ccivil_03/_ato2007-2010/2008/lei/l11741.htm>. Acesso em 5 maio 2010.

Parecer CNE/CEB no 11, de 12 de junho de 2008. Assunto: Proposta de instituição de Catálogo Nacional de Cursos Técnicos de nível médio. 2008b. Disponível em: <http://portal.mec.gov.br/setec/arquivos/pdf/pceb011_08.pdf>. Acesso em 5 maio 2010.

Lei no 11.892, de 29 de dezembro de 2008. Institui a rede federal de Educação Profissional, Científica e tecnológica, cria os Institutos federais de Educação, Ciência e tecnologia, e dá outras providências. 2008c. Disponível em: <https://www.planalto.gov.br/ccivil_03/_ato2007-2010/2008/lei//11892.htm>. Acesso em 5 maio 2010.

- Ministério da Educação. Instituto Nacional de Estudos e Pesquisas Educacionais Anísio Teixeira. Exame Nacional do Ensino Médio. 2009a. Disponível em: http://sistemasenem4.inep.gov.br/enemMediasEscola/. Acesso em: 19 out. $2010 b$.

Ensino Médio Inovador. 2009b. Disponível em: <http://portal.mec.gov.br/ dmdocuments/ensino_medioinovador.pdf>. Acesso em 10 mar. 2010.

. Censo Escolar 2009 - Sinopse Estatística da Educação Básica. 2009c. Disponível em: <http://www.inep.gov.br/basica/censo/Escolar/Sinopse/sinopse.asp>. Acesso em 19 maio 2010. 
catalogonct.mec.gov.br/>. Acesso em 20 jun. 2010.

. CONAE 2010 - Conferência Nacional de Educação. Construindo o sistema nacional articulado de educação: O Plano Nacional de Educação, diretrizes e estratégias de ação. Documento Final. 2010b. Disponível em: <http://conae.mec. gov.br/images/stories/pdf/pdf/documento_final.pdf>. Acesso em 13 jun. 2010.

Resolução CNE/CES no 5, de 15 de março de 2011. Institui as Diretrizes Curriculares Nacionais para os cursos de graduação em Psicologia, estabelecendo normas para o projeto pedagógico complementar para a formação de Professores de Psicologia. Disponível em: <http://abepsi.org.br/site/wp-content/uploads/2010/12/ resolucaodiretrizes2011.pdf>. Acesso em 20 abr. 2011.

BVS-PSI - Biblioteca Virtual em Saúde - Psicologia. Dicionário biográfico da psicologia no Brasil. 2010. Disponível em: <http://www.bvs-psi.org.br>. Acesso em 2 jun. 2010.

CARONE, Iray. A psicologia tem paradigmas? São Paulo: Casa do Psicólogo, Fapesp, 2003.

. Os efeitos encantatórios da forma-mercadoria. In: ABRANTES, Angelo Antonio; SILVA, Nilma Renildes da; MARTINS, Sueli Terezinha Ferreira. Método histórico-social na psicologia social. Rio de Janeiro: Vozes, 2005. p. 19-24.

CARVALHO, José Sérgio. Direitos humanos, formação escolar e esfera pública. 2008. Disponível em: <http://www2.fe.usp.br/ cpedh/Direitos\%20humanos,\%20 formacao\%20escolar\%20e\%20esf\%20publ\%20Ze\%20Segio.pdf>. Acesso em 23 maio 2010.

CASTANHO, Sérgio. Institucionalização das instituições escolares: final do Império e Primeira República no Brasil. In: NASCIMENTO, Maria Isabel Moura; SANDANO, Wilson; LOMBARDI, José Claudinei; SAVIANI, Dermeval (orgs.). Instituições escolares no Brasil: Conceito e reconstrução histórica. Campinas: Autores Associados e HISTEDBR; Sorocaba: Uniso; Ponta Grossa: UEPG, 2007. p. 39-57.

CHATAWAY, Cynthia J. Negotiating the observer-observed relationship: participatory action research. In: TOLMAN, Deborah L.; BRYDON-MILLER, Mary. (orgs). From subjects to subjectivities - a handbook of interpretative and participatory methods. New York: New York University Press, 2001. p. 239-255.

CHAUÍ, Marilena de Sousa. O que é ideologia. São Paulo: Brasiliense, 1981. 
CIRINO, Sergio Dias et al. As novas diretrizes curriculares: uma reflexão sobre a licenciatura em Psicologia. In: Temas em Psicologia, vol. 15, oㅡ 1, p. 23-32, 2007.

CONSELHO FEDERAL DE PSICOLOGIA. Contribuições da Psicologia para o CONAE/Conselho Federal de Psicologia. Brasília: CFP, 2010.

CONSELHO REGIONAL DE PSICOLOGIA. (São Paulo). Psicologia no ensino de 20 grau: uma proposta emancipadora. Conselho Regional de Psicologia, 6으 região, Sindicato de Psicólogos no Estado de São Paulo. São Paulo: EDICON, 1986.

Psi Jornal de Psicologia - CRP-SP. no 156, maio-jun. 2008.

CÔRREA, Vera. A nova cultura do trabalho: subjetividades e novas identidades dos trabalhadores. In: FRIGOTTO, Gaudêncio; CIAVATTA, Maria (orgs.). A formação do cidadão produtivo: a cultura do mercado no ensino médio técnico. Brasília: Instituto Nacional de Estudos e Pesquisas Educacionais Anísio Teixeira, 2006. p. 237-257.

CUNHA, Luis Antonio. $O$ ensino de ofícios nos primórdios da industrialização. São Paulo, Brasília: UNESP, Flacso, 2000.

As agências financeiras internacionais e a reforma brasileira do Ensino Técnico: a crítica da crítica. In: ZIBAS, Dagmar Maria Leopoldi; Aguiar, Márcia Ângela da Silva, Simões, Maria Sylvia (orgs). 0 ensino médio e a reforma da educação básica. Brasília: Plano, 2002. p. 103-134.

CURY, Carlos Roberto Jamil. O Ensino Médio no Brasil: histórico e perspectivas. In: Educação em Revista. Belo Horizonte: Faculdade de Educação da UFMG, № 27, p. 73-84, jul. 1998.

DADICO, Luciana. Práticas educacionais distintas: a psicologia no ensino médio paulista. In: Cadernos de Pesquisa, vol. 39, oㅜ 137, p. 421-440, maio-ago. 2009.

DENZIN, Norman K.; LINCOLN, Yvonna S. A disciplina e a prática da pesquisa qualitativa. In: O planejamento da pesquisa qualitativa: teorias e abordagens. Porto Alegre: Artmed e Boockman, 2006. p. 15-41.

DUARTE, Newton. Formação do indivíduo, consciência e alienação: o ser humano na psicologia de A.N. Leontiev. In: Caderno Cedes, Campinas, vol. 24, n. 62, p. 44-63, abri. 2004. 
FALCIN, Daniela Cavani. Afetividade e condições de ensino: histórias de professores inesquecíveis. In: LEITE, Sérgio Antônio da Silva (org.). Afetividade e práticas pedagógicas. São Paulo: Casa do Psicólogo, 2006. p. 75-96.

FAUSTO, Boris. História Concisa do Brasil. São Paulo: EDUSP, 2001.

FERRETI, Celso João; SILVA JúNIOR, João dos Reis. Educação Profissional numa sociedade sem empregos. In: Cadernos de Pesquisa, nำ109, p. 43-66, mar. 2000.

FREIRE, Paulo. Pedagogia da autonomia: saberes necessários à prática educativa. São Paulo: Paz e Terra, 1996.

FRIGOTTO, Gaudêncio. A relação da Educação Profissional e Tecnológica com a universalização da Educação Básica. In: Educação e Sociedade, vol. 28, no 100 Especial, p. 1129-1152, out. 2007.

FRIGOTTO, Gaudêncio; CIAVATTA, Maria. Educação básica no Brasil na década de 1990: Subordinação ativa e consentida à lógica do mercado. In: Educação e Sociedade, Campinas, vol. 24, n. 82, p. 93-130, abr. 2003.

. Educar o trabalhador cidadão produtivo ou o ser humano emancipado. In: (orgs). A formação do cidadão produtivo: a cultura do mercado no ensino médio técnico. Brasília: Instituto Nacional de Estudos e Pesquisas Educacionais Anísio Teixeira, 2006a. p. 55-70.

Os embates da reforma do ensino técnico: resistência, adesão e consentimento. In: (orgs). A formação do cidadão produtivo: a cultura do mercado no ensino médio técnico. Brasília: Instituto Nacional de Estudos e Pesquisas Educacionais Anísio Teixeira, 2006b. p. 343-372.

FRIGOTTO, Gaudêncio; CIAVATTA, Maria; RAMOS, Marise. A política de educação profissional no governo Lula: um percurso histórico controvertido. In: Educação e Sociedade, Campinas, vol. 26, n. 92, p. 1087-1113, out. 2005. Número especial.

GEERTZ, Clifford. Uma descrição densa: por uma teoria interpretativa da Cultura. In: . A interpretação das culturas. Rio de Janeiro: LTC, 1989. p. 13-41.

GONÇALVES, Maria da Graça Marchina. O método de pesquisa materialista histórico e dialético. In: ABRANTES, Angelo Antonio; SILVA, Nilma Renildes da; MARTINS, Sueli Terezinha Ferreira. Método histórico-social na psicologia social. Rio de 
Janeiro: Vozes, 2005. p. 86-104.

HELLER, Agnes. Sociología de la vida cotidiana. Barcelona: Península, 1987.

HORKHEIMER, Max; ADORNO, Theodor W. Dialética do esclarecimento. Rio de Janeiro: Jorge Zahar Ed., 1985.

KOHATSU, Lineu Norio. A reinserção da disciplina de psicologia no ensino médio: as especificidades da psicologia e os desafios do atual contexto educacional. In:

Psicologia: Ensino e formação, vol. 1, oㅜ 1, p. 53-66, abr. 2010.

KOSIK, Karel. O mundo da pseudoconcreticidade e sua destruição. In:

Dialética do concreto. Rio de Janeiro: Paz e Terra, 1976. p. 13-25.

KUENZER, Acácia Zeneida. Capítulos 1, 2, 3 e 4. (org.). Ensino Médio: construindo uma proposta para os que vivem do trabalho. São Paulo: Cortez, 2005. p. 25-93.

Da dualidade assumida a dualidade negada: o discurso da flexibilização justifica a inclusão excludente. In: Educação e Sociedade, vol. 28, № 100 - Especial, p. 1153-1178, out. 2007a.

Ensino médio e profissional: as políticas do Estado neoliberal. 4 ed. São Paulo: Cortez, 2007b.

LEITE, Sergio Antônio da Silva. Afetividade e práticas pedagógicas. In:

(org.). Afetividade e práticas pedagógicas. São Paulo: Casa do Psicólogo, 2006. p. $15-45$.

Psicologia no Ensino Médio: desafios e perspectivas. In: Temas em

Psicologia, vol. 15, № 1, p. 11-21, 2007.

LEMOS, Letícia Siqueira. A identidade do licenciado em Psicologia: uma análise das regulamentações brasileiras entre 1962 e 2008. 112f. Dissertação (Mestrado em educação) - Faculdade de Educação, Universidade Federal de Minas Gerais, 2008.

LEONTIEV, Alexis N. O desenvolvimento do psiquismo. Lisboa: Livros Horizonte, 1978. 
MACIEL, Mariana Sobreira. Cursos técnicos: um campo de atuação para o licenciado em Psicologia na cidade de Belo Horizonte. 113f. Dissertação (Mestrado em educação) - Faculdade de Educação, Universidade Federal de Minas Gerais, 2009.

MARTINS, Lígia Márcia. Psicologia sócio-histórica: o fazer científico. In: ABRANTES, Angelo Antonio; SILVA, Nilma Renildes da; MARTINS, Sueli Terezinha Ferreira. Método histórico-social na psicologia social. Rio de Janeiro: Vozes, 2005. p. 118-138.

. As aparências enganam: divergências entre o Materialismo Histórico Dialético e as abordagens qualitativas de pesquisa. In: 29 Reunião Anual da Associação Nacional de Pós-graduação e Pesquisa em Educação. Minas Gerais, 2006. Anais eletrônicos. Disponível em: <http://www.anped.org.br/ reunioes/29ra/trabalhos/trabalho/GT17-2042--Int.pdf>. Acesso em 08 jun. 2010.

MARX, Karl. Manuscritos econômico-filosóficos. São Paulo: Boitempo Editorial. 2008.

MASSIMI, Marina. Projetos de lei prevendo a inserção da psicologia nos currículos do ensino superior e secundário no Brasil do século XIX. In: Psicologia: Teoria e Pesquisa, vol. 9, n. 2, p. 261-269, maio-ago. 1993.

MERCADO, Ruth. Los saberes docentes como construcción social. La enseñanza centrada em los niños. México: Fondo de Cultura Econômica, 2002.

MICHAELIS moderno dicionário da Língua Portuguesa. São Paulo: Melhoramentos, 2004. Disponível em: <http://michaelis.uol.com.br/moderno/portugues/index. php?lingua=portugues-portugues $>$. Acesso em 28 maio 2011.

MOACYR, Primitivo. A instrução pública no estado de São Paulo. São Paulo: Companhia Editora Nacional, 1942. vol. 1 e 2.

MORAES, Carmem Sylvia Vidigal. Notas históricas sobre origens do Ensino Técnico no Estado de São Paulo. In: MORAES, Carmen Sylvia Vidigal; ALVES, Julia Falivene (coords.). Inventário de fontes documentais. São Paulo: Imprensa Oficial do Estado-FAPESP, 2002a. p. 47-50.

O Ensino Técnico, a formação profissional e o mundo do trabalho: algumas questões de método. In: ZIBAS, Dagmar; AGUIAR, Marcia; BUENO, Maria. O Ensino Médio e a reforma da Educação Básica. Brasília: Plano Editora, 2002b. p. 201-224. 
MORAIS, I.; et al. Orientação escolar e profissional em escolas da região centro com ensino técnico-profissional. In: Cadernos de consulta psicológica, vol. 1, p. 131-137, 1985.

MRECH, Leny Magalhães. Casa de ferreiro, espeto de pau: o campo da psicologia no ensino médio: dilemas e perspectivas. In: SEVERINO, Antonio Joaquim; FAZENDA, Ivana Catarina Arantes. (orgs). Conhecimento, pesquisa e educação. Campinas: Papirus, 2001. p. 143-160.

. Um breve histórico a respeito do ensino de psicologia no ensino médio. In:

ETD - Educação Temática Digital, Campinas, vol. 8, № 2, p. 225-237, jun. 2007.

OLIVEIRA, Betty. A dialética do singular-particular-universal. In: ABRANTES, Angelo Antonio; SILVA, Nilma Renildes da; MARTINS, Sueli Terezinha Ferreira. Método histórico-social na psicologia social. Rio de Janeiro: Vozes, 2005. p. 25-51.

OLIVEIRA, Maria Rita Neto Sales. O Ensino Técnico, o mundo do trabalho e questões didáticas: pontos para reflexão. In: ZIBAS, Dagmar; AGUIAR, Marcia; BUENO, Maria. O Ensino Médio e a reforma da Educação Básica. Brasília: Plano Editora, 2002. p. 279-298.

OLIVEIRA, Ramon de. Algumas questões para pensar a educação de nível técnico e a qualificação profissional. In: ZIBAS, Dagmar; AGUIAR, Marcia; BUENO, Maria. 0 Ensino Médio e a reforma da Educação Básica. Brasília: Plano Editora, 2002. p. 259-278.

PATTO, Maria Helena Sousa. Psicologia e ideologia: uma introdução crítica à psicologia escolar. São Paulo: T. A. Queiroz, 1984.

PIRES, Fernanda Hampe. O ensino de Psicologia na educação profissional: (des) compromissos docentes com a saúde. 214f. Dissertação (Mestrado em educação) Faculdade de Educação, Universidade Federal do Rio Grande do Sul, 2009.

RAMOS, Marise Nogueira. A pedagogia das competências: autonomia ou adaptação. 3 ed. São Paulo: Cortez, 2006.

RANIERI, Jesus. Apresentação. In: MARX, Karl. Manuscritos econômicofilosóficos. São Paulo; Boitempo Editorial, 2008. p. 11-18.

REY, Fernando Luis González. Pesquisa qualitativa em psicologia: caminhos e 
desafios. São Paulo: Pioneira Thomson Learning, 2005.

ROCHA, Pedro Adilson da Silva. O SENAI na constituição de identidade de seus alunos. 183f. Tese (Doutorado em educação - Psicologia da Educação), Pontifícia Universidade Católica, 2005.

ROCKWELL, Elsie. Reflexiones sobre el trabajo etnográfico. In: La experiencia etnográfica: historia y cultura en los procesos educativos. Buenos Aires: Paidós, 2009a. p. 41-96.

. La etnografia en el archivo. In: La experiencia etnográfica: historia y cultura en los procesos educativos. Buenos Aires: Paidós, 2009b. p. 147-181.

SÃO PAULO (Estado). Secretaria da Educação. Coordenadoria de estudos e normas pedagógicas. Proposta curricular de psicologia para o ensino de 2 o grau. São Paulo: SE/CENP, 1992.

. Centro Estadual de Educação Tecnológica. Deliberação Ceeteps № 2, de 7 de junho de 2004. Fixa norma para funcionamento de cursos de educação profissional de nível técnico nas Escolas Técnicas Estaduais - ETEs. Disponível em: $<$ http://www.cpscetec.com.br/supervisao/deliberacao2.pdf>. Acesso em 24 nov. 2010.

Secretaria de Estado da Educação. Resolução SE no 92, de 19 de dezembro de 2007. Estabelece diretrizes para organização curricular do Ensino Fundamental e Médio na escolas estaduais. Disponível em: <http://cenp.edunet. sp.gov.br/Portal/ensino/resolucao_se_92_em.pdf>. Acesso em 11 mar. 2010.

. Governo do Estado de São Paulo. Disponível em: <www.saopaulo.sp.gov. br/fatecetec >. Acesso em: 4 ago. 2009.

Secretaria de Desenvolvimento. Disponível em: <http://www. centropaulasouza.sp.gov.br/QuemSomos/Secretaria/Secretaria.html>. 2010a. Acesso em: 20 out. 2010.

Centro Paula Souza. Disponível em: <http://www.centropaulasouza.sp.gov. br/>. 2010b. Acesso em: 4 maio 2010.

Decreto no 56.635 de 1ㅇ de janeiro de 2011. Dispõe sobre as alterações de denominação e transferências que especifica, define a organização básica da 
Administração Direta e suas entidades vinculadas e dá providências correlatas. 2011a. Disponível em: <http://www.desenvolvimento.sp.gov.br/secretaria//files/ decretos_56635_e_56636_2011.pdf>. Acesso em 19 abr. 2010.

Decreto o 56.636 de 10 de janeiro de 2011. Organiza a Secretaria de Desenvolvimento Econômico, Ciência e Tecnologia e dá providências correlatas. 2011b. Disponível em: <http://www.desenvolvimento.sp.gov.br/secretaria//files/ decretos_56635_e_56636_2011.pdf>. Acesso em 19 abr. 2010.

. Secretaria de Desenvolvimento. Ensino profissionalizante. Disponível em: <http://www.desenvolvimento.sp.gov.br/ensino/>. 2011c. Acesso em: 28 jan. 2011.

SAVIANI, Dermeval. Pedagogia histórico-crítica: primeiras aproximações. Campinas: Autores Associados, 2000.

A nova lei da educação: trajetória, limites e perspectivas. 10 ed. Campinas, SP: Autores Associados, 2006.

Da nova LDB ao FUNDEB: por uma nova política educacional. Campinas, SP: Autores Associados, 2007.

Escola e democracia: teorias da educação, curvatura da vara, onze teses sobre a educação política. 40 ed. Campinas, SP: Autores Associados, 2008.

SAVIANI, Dermeval; DUARTE, Newton. A formação humana na perspectiva histórico-ontológica. In: Revista Brasileira de Educação, vol. 15, n. 45, p. 422-433, set.-dez. 2010.

SCHWARTZMAN, Simon; BOMENY, Maria Bousquet; COSTA, Vanda Maria Ribeiro. Tempos de Capanema. Rio de Janeiro: Paz e Terra; São Paulo: EDUSP, 1984.

SEKKEL, Marie Claire; MACHADO, Adriana Marcondes. O projeto pedagógico do curso de formação de professores de Psicologia do Instituto de Psicologia da USP. In: Temas em Psicologia, vol. 15, № 1, p. 127-134, 2007.

SIMÕES, Sônia Pires; PAIVA, Maria das Graças Vasconcelos. Licenciatura em psicologia: legislação e nova proposta curricular na Universidade do Estado Rio de Janeiro. In: Temas em Psicologia, vol. 15, n. 1, p. 115-125, 2007. 
SKINNER, Burrhus Frederic. Ciência e comportamento humano. Brasília: Editora da Universidade de Brasília, 1970.

Sobre o behaviorismo. São Paulo: Cultrix, 1982.

SOLIGO, Ângela. Psicologia no Ensino Médio: reflexões em torno da formação. In: Ensino de Psicologia no nível médio: impasses e alternativas. Disponível em: $<$ http://www.crpsp.org.br/portal/comunicacao/cadernos_tematicos/9/frames/fr_psi_ ensino_medio.aspx>. Acesso em: 29 jan. 2011.

SOLIGO, Ângela; AZZI, Roberta. Psicologia no Ensino Médio. In: CONSELHO FEDERAL DE PSICOLOGIA. Seminário nacional do ano da educação psicologia: Profissão na construção da educação para todos. Brasília: CFP, 2009. p. 56-64.

SOUZA, Marilene Proença Rebello de. A psicologia escolar e o ensino de psicologia: Dilemas e perspectivas. In: ETD - Educação Temática Digital, Campinas, vol. 8, no 2, p. 258-265, jun. 2007.

STUTZ, Beatriz Lemos; JANSEN, Adriane Corrêa. Ensino técnico na área da saúde: os desafios do processo de aprendizagem. In: Psicologia Escolar e Educacional, vol. 10, n. 2, p. 211-222, 2006.

TONET, Ivo. Educação, cidadania e emancipação humana. ljuí: Editora Unijuí, 2005.

. Educação contra o capital. Maceió: Edufal, 2007

TELES, Antonio Xavier. Psicologia Moderna. 35 ed. São Paulo: Ática, 1999.

VENDRAMETO. Maria Cristina. Da escola da capital (São Paulo) à Escola Técnica Estadual Getúlio Vargas: uma proposta de gestão documental. $142 f$. Dissertação (Mestrado em Educação - Faculdade de Educação). Universidade de São Paulo, 2005.

WOOD, Ellen Meiksins. Democracia contra capitalismo: a renovação do materialismo histórico. São Paulo: Boitempo, 2003. 
desdobramentos das políticas dos anos de 1990. In: Educação e Sociedade. Campinas, vol. 26, oo 92 - Especial, p. 1067-1086, out. 2005.

ZULKE, Maria Inês Utzig. A reforma do Estado e os processos de subjetivação: um estudo sobre o trabalho do servidor público em instituição de educação profissional. 95f. Dissertação (Mestrado em Psicologia Social e Institucional) Instituto de psicologia, Universidade Federal do Rio Grande do Sul, 2007. 
APÊNDICE A - Quadros contendo autor, título, classificação e referência dos artigos encontrados por meio da revisão bibliográfica.

\section{Resultado da busca por meio do Portal Capes com as bases de dados Psyclnfo; Scielo; Web of Science, SCOPUS.}

Termos-chave: "escola tecnica" e psicologia

\begin{tabular}{|c|c|c|c|c|}
\hline № & Autor & Título & $\begin{array}{l}\text { Relação com } \\
\text { tema }\end{array}$ & Publicado em \\
\hline 1 & $\begin{array}{l}\text { Camargo, } \\
\text { B.V. }\end{array}$ & $\begin{array}{l}\text { A influência de vídeos documentários na } \\
\text { divulgação científica de conhecimento sobre } \\
\text { a aids. }\end{array}$ & $\begin{array}{l}\text { Não } \\
\text { relacionada }\end{array}$ & $\begin{array}{l}\text { Psicologia Reflexão e Critica. } \\
2008 \text {, vol. 21, n. 2, p. 179-185. }\end{array}$ \\
\hline 2 & Masjuan, J.M. & $\begin{array}{l}\text { El contexto de enseñanza un elemento } \\
\text { fundamental en la implementación de } \\
\text { innovaciones pedagógicas relacionadas con } \\
\text { los créditos Europeos }\end{array}$ & $\begin{array}{l}\text { Não } \\
\text { relacionada }\end{array}$ & $\begin{array}{l}\text { Revista complutense de } \\
\text { educación. 2009, vol. 20, n. 2, p. } \\
355-380\end{array}$ \\
\hline 3 & $\begin{array}{l}\text { Carrillo, A.G. , } \\
\text { et al. }\end{array}$ & $\begin{array}{l}\text { Metodología de enseñanza-aprendizaje en } \\
\text { diseño de proyectos de ingeniería }\end{array}$ & $\begin{array}{l}\text { Não } \\
\text { relacionada }\end{array}$ & $\begin{array}{l}\text { Afinidad. Maio } 2007 \text {, vol. } 64, \mathrm{n} . \\
529, \text { p. } 456-463\end{array}$ \\
\hline
\end{tabular}

Termos-chave: "escola profissional" e psicologia

\begin{tabular}{cllll}
\hline № & Autor & Título & $\begin{array}{l}\text { Relação com } \\
\text { tema }\end{array}$ & Publicado em \\
\hline & Mendes & Atribuição causal e expectativas de sucesso & \\
\hline & $\begin{array}{l}\text { Monteiro, M. } \\
\text { H. }\end{array}$ & $\begin{array}{l}\text { Não a alunos do 20 ciclo. } \\
\text { relacionada }\end{array}$ & Maio 2000, vol. 4 (1), p. 105-125 \\
\hline
\end{tabular}

Termos-chave: "ensino tecnico" e psicologia

\begin{tabular}{cllll}
\hline № & Autor & Título & $\begin{array}{l}\text { Relação com } \\
\text { tema }\end{array}$ & Publicado em \\
\hline \multirow{3}{*}{$\begin{array}{l}\text { Morais, l; et } \\
\text { al. }\end{array}$} & $\begin{array}{l}\text { Orientação Escolar e Profissional em } \\
\text { Escolas da Região Centro com Ensino } \\
\text { Técnico-Profissional. }\end{array}$ & Relacionada & $\begin{array}{l}\text { Cadernos de } \\
\text { Consulta psicológica. 1985, vol 1, } \\
\text { p. 131-137 }\end{array}$ \\
\hline
\end{tabular}

Com os termos "ensino profissional" e psicologia; "educação tecnica" e psicologia; "educação profissional" e psicologia: não se obteve nenhum resultado.

\section{Resultado da busca por meio da Biblioteca Virtual em Saúde - Psicologia.}

Termos-chave: (ensino tecnico) psicologia:

\begin{tabular}{|c|c|c|c|c|}
\hline № & Autor & Título & $\begin{array}{l}\text { Relação com } \\
\text { tema }\end{array}$ & Publicado em \\
\hline 1 & $\begin{array}{l}\text { Stutz, B. L.; } \\
\text { Jansen, A. C. }\end{array}$ & $\begin{array}{l}\text { Ensino técnico na área da saúde: os desafios } \\
\text { do processo de aprendizagem }\end{array}$ & Relacionada & $\begin{array}{l}\text { Psicologia escolar e } \\
\text { educacional. 2006, vol. } 10 \text { (2), } \\
\text { p. 211-222. }\end{array}$ \\
\hline 2 & Bleger, J. & Temas de psicologia: entrevista de grupos & $\begin{array}{l}\text { Não } \\
\text { relacionada }\end{array}$ & $\begin{array}{l}\text { São Paulo: Martins Fontes, } \\
2001\end{array}$ \\
\hline 3 & Presa, L. A.P. & Mensuração de raiva em motoristas: STAXI & $\begin{array}{l}\text { Não } \\
\text { relacionada }\end{array}$ & São Paulo: Vetor, 2002. \\
\hline 4 & $\begin{array}{l}\text { Cruz, D. de } \\
\text { A.L.M. da; et al. }\end{array}$ & $\begin{array}{l}\text { Percepção de poder de enfermeiras frente a } \\
\text { seu papel clínico }\end{array}$ & $\begin{array}{l}\text { Não } \\
\text { relacionada }\end{array}$ & $\begin{array}{l}\text { Revista Latino-americana de } \\
\text { enfermagem, mar.-abr. } 2009 \text {, } \\
\text { vol. } 17 \text { (2), p. 234-239. }\end{array}$ \\
\hline 5 & Grossman, E. & $\begin{array}{l}\text { Os objetos e os ambientes físicos para a } \\
\text { saúde: um olhar com ciência e arte sobre os } \\
\text { laboratórios do Instituto Oswaldo Cruz - } \\
\text { Fiocruz }\end{array}$ & $\begin{array}{l}\text { Não } \\
\text { relacionada }\end{array}$ & $\begin{array}{l}\text { Tese defendida no Instituto } \\
\text { Oswaldo Cruz em } 2008 .\end{array}$ \\
\hline 6 & Witter, G. P. & Leitura e Psicologia & $\begin{array}{l}\text { Não } \\
\text { relacionada }\end{array}$ & Campinas, SP: Alínea, 2004. \\
\hline 7 & $\begin{array}{l}\text { Perfeito, } \\
\text { H.C.C.S.; Melo, } \\
\text { S.A. de }\end{array}$ & $\begin{array}{l}\text { Evolução dos processos de triagem } \\
\text { psicológica em uma clínica-escola }\end{array}$ & $\begin{array}{l}\text { Não } \\
\text { relacionada }\end{array}$ & $\begin{array}{l}\text { Estudos de psicologia. } \\
\text { Campinas. Jan. - abri. 2004, } \\
\text { vol. 21(1), p. 33-42. }\end{array}$ \\
\hline
\end{tabular}




\begin{tabular}{|c|c|c|c|c|}
\hline 8 & $\begin{array}{l}\text { Kaspary, N.; et } \\
\text { al. }\end{array}$ & $\begin{array}{l}\text { Estilo de vida de mulheres adultas obesas da } \\
\text { cidade de Cruz Alta-RS }\end{array}$ & $\begin{array}{l}\text { Não } \\
\text { relacionada }\end{array}$ & $\begin{array}{l}\text { Revista de educação física. } \\
2006 \text {, vol. } 17(2) \text {, p. 193-201. }\end{array}$ \\
\hline 9 & $\begin{array}{l}\text { Scherer, Z. A.P.; } \\
\text { Scherer, E.A.; } \\
\text { Carvalho, } \\
\text { A.M.P. }\end{array}$ & $\begin{array}{l}\text { Group therapy with nursing students during } \\
\text { the theory-practice transition }\end{array}$ & $\begin{array}{l}\text { Não } \\
\text { relacionada }\end{array}$ & $\begin{array}{l}\text { Revista latino americana de } \\
\text { enfermagem. Mar.-abri. 2007, } \\
\text { vol. } 15(2) \text {, p. } 214-223 .\end{array}$ \\
\hline 10 & $\begin{array}{l}\text { Mattos, D.; } \\
\text { Dreyer, G. }\end{array}$ & $\begin{array}{l}\text { A filariose bancroftiana: uma perspectiva } \\
\text { psicossocial e política para os profissionais } \\
\text { da saúde }\end{array}$ & $\begin{array}{l}\text { Não } \\
\text { relacionada }\end{array}$ & $\begin{array}{l}\text { Revista panamericana de } \\
\text { infectologia. Abr.-jun. } 2006 \text {, vol. } \\
8(2) \text {, p. } 35-39 \text {. }\end{array}$ \\
\hline 11 & Sant'ana, I. M. & $\begin{array}{l}\text { Educação inclusiva: concepções de } \\
\text { professores e diretores }\end{array}$ & $\begin{array}{l}\text { Não } \\
\text { relacionada }\end{array}$ & $\begin{array}{l}\text { Psicologia em estudo. Maio- } \\
\text { ago. } 2005 \text {, vol. } 10(2) \text {, p. } 227- \\
234 .\end{array}$ \\
\hline 12 & Ferreira, J.R. & Humanizando o ambiente do estudo & $\begin{array}{l}\text { Não } \\
\text { relacionada }\end{array}$ & $\begin{array}{l}\text { Arquivo ciências da saúde da } \\
\text { UNIPAR. Jan.-abr. 2003, vol. } \\
7(1), \text { p. } 83-84 .\end{array}$ \\
\hline 13 & $\begin{array}{l}\text { Rebello, S.; } \\
\text { Monteiro, S.; } \\
\text { Vargas, E. P. }\end{array}$ & $\begin{array}{l}\text { A visão de escolares sobre drogas no uso de } \\
\text { um jogo educativo }\end{array}$ & $\begin{array}{l}\text { Não } \\
\text { relacionada }\end{array}$ & $\begin{array}{l}\text { Interface (Botucatu). 2001, vol. } \\
5(8), \text { p. } 75-88 .\end{array}$ \\
\hline 14 & Aguiar, R.V. & $\begin{array}{l}\text { Comunicação interpessoal entre cliente e } \\
\text { aluno do curso técnico em enfermagem à luz } \\
\text { do referencial de l. King }\end{array}$ & $\begin{array}{l}\text { Não } \\
\text { Relacionada }\end{array}$ & $\begin{array}{l}\text { Dissertação defendida na UFPR } \\
\text { em } 2000 \text {. }\end{array}$ \\
\hline 15 & Aquino, J.R.G. & $\begin{array}{l}\text { Relação professor-aluno: uma leitura } \\
\text { institucional }\end{array}$ & $\begin{array}{l}\text { Não } \\
\text { relacionada }\end{array}$ & $\begin{array}{l}\text { Tese defendida no Instituto de } \\
\text { Psicologia da USP em } 1995\end{array}$ \\
\hline 16 & Gonçalves, E.L. & A medicina no Brasil, hoje: ensino e prática & $\begin{array}{l}\text { Não } \\
\text { relacionada }\end{array}$ & $\begin{array}{l}\text { Revista do Hospital das } \\
\text { Clínicas. Jul.-ago. 1990, vol. } \\
\text { 45(4), p. 190-193. }\end{array}$ \\
\hline 17 & Crochík, J.L. & $\begin{array}{l}\text { O ajustamento do pensamento em uma } \\
\text { sociedade de alto desenvolvimento } \\
\text { tecnológico: o computador no ensino }\end{array}$ & $\begin{array}{l}\text { Não } \\
\text { relacionada }\end{array}$ & $\begin{array}{l}\text { Tese defendida no Instituto de } \\
\text { Psicologia da USP em } 1990 .\end{array}$ \\
\hline 18 & $\begin{array}{l}\text { Simões, S.P.; } \\
\text { Paiva, M. das } \\
\text { G.V. }\end{array}$ & $\begin{array}{l}\text { Licenciatura em Psicologia: legislação e nova } \\
\text { proposta curricular na Universidade do } \\
\text { Estado Rio de Janeiro. }\end{array}$ & Relacionada & $\begin{array}{l}\text { Temas em psicologia. 2007. vol. } \\
\text { 15(1), p. } 115-125 .\end{array}$ \\
\hline 19 & Gomes, W.B. & $\begin{array}{l}\text { Distinção entre procedimentos técnico e } \\
\text { lógico na análise fenomenológica }\end{array}$ & $\begin{array}{l}\text { Não } \\
\text { relacionada }\end{array}$ & $\begin{array}{l}\text { Revista abordagem } \\
\text { gestaltaltica. Jul.-dez. 2007, vol. } \\
\text { XIII(2), p. 228-240. }\end{array}$ \\
\hline 20 & $\begin{array}{l}\text { Oliveira, K.L. de; } \\
\text { Santos, A.A.A. } \\
\text { dos }\end{array}$ & $\begin{array}{l}\text { Compreensão de textos e desempenho } \\
\text { acadêmico }\end{array}$ & $\begin{array}{l}\text { Não } \\
\text { relacionada }\end{array}$ & $\begin{array}{l}\text { Psic: revista da vetor editora. } \\
2006 \text {, vol. } 7(1), \text { p. } 19-27 .\end{array}$ \\
\hline 21 & $\begin{array}{l}\text { Santos, V.L.C. } \\
\text { de G.; Sawaia, } \\
\text { B.B. }\end{array}$ & $\begin{array}{l}\text { A bolsa na mediação "estar ostomizado" - } \\
\text { "estar profissional": análise de uma } \\
\text { estratégia pedagógica }\end{array}$ & $\begin{array}{l}\text { Não } \\
\text { relacionada }\end{array}$ & $\begin{array}{l}\text { Revista latino-americana de } \\
\text { enfermagem. Jul. } 2000 \text {, vol. } \\
8(3) \text {, p. } 40-\text { p. } 50 .\end{array}$ \\
\hline 22 & $\begin{array}{l}\text { Aguiar, J.S. de; } \\
\text { Duarte, E. }\end{array}$ & $\begin{array}{l}\text { Educação inclusiva: um estudo na área da } \\
\text { educação física }\end{array}$ & $\begin{array}{l}\text { Não } \\
\text { relacionada }\end{array}$ & $\begin{array}{l}\text { Revista brasileira de educação } \\
\text { especial. Maio-ago. } 2005 \text {, vol. } \\
11(2) \text {, p. } 223-240 .\end{array}$ \\
\hline 23 & $\begin{array}{l}\text { Silva, C.M.C. da; } \\
\text { Sabóia, V.M.; } \\
\text { Teixeira, E.R. }\end{array}$ & $\begin{array}{l}\text { O ensino do exame físico em suas } \\
\text { dimensões técnicas e subjetivas }\end{array}$ & $\begin{array}{l}\text { Não } \\
\text { relacionada }\end{array}$ & $\begin{array}{l}\text { Texto e contexto - } \\
\text { Enfermagem. Jul.-set. } 2009 \text {, } \\
\text { vol. } 18(3) \text {, p. } 458-465 .\end{array}$ \\
\hline 24 & $\begin{array}{l}\text { Gorni, D.A.P.; } \\
\text { Santos, A.F. dos }\end{array}$ & $\begin{array}{l}\text { Das séries aos ciclos de estudos: o desafio } \\
\text { da (des)continuidade }\end{array}$ & $\begin{array}{l}\text { Não } \\
\text { relacionada }\end{array}$ & $\begin{array}{l}\text { Ensaio: avaliação e políticas } \\
\text { públicas em educação. Out.- } \\
\text { dez. 2009, vol. 17(65), p. } 675- \\
694 .\end{array}$ \\
\hline 25 & $\begin{array}{l}\text { Angelucci, C. B., } \\
\text { et al. }\end{array}$ & $\begin{array}{l}\text { O estado da arte da pesquisa sobre o } \\
\text { fracasso escolar (1991-2002): um estudo } \\
\text { introdutório. }\end{array}$ & $\begin{array}{l}\text { Não } \\
\text { relacionada }\end{array}$ & $\begin{array}{l}\text { Educação e pesquisa. Jan.-abr. } \\
2004 \text {, vol. } 30(1) \text {, p. } 51-72 .\end{array}$ \\
\hline
\end{tabular}

Termos-chave: (escola tecnica) psicologia

\begin{tabular}{|c|c|c|c|c|}
\hline № & Autor & Título & $\begin{array}{l}\text { Relação com } \\
\text { o tema }\end{array}$ & Publicado em \\
\hline 1 & Araújo, S.T.C. de & $\begin{array}{l}\text { Os sentidos corporais dos estudantes no } \\
\text { aprendizado da comunicação não-verbal } \\
\text { do cliente na recepção pré-operatória: } \\
\text { uma semiologia da expressão através da } \\
\text { sociopoética }\end{array}$ & $\begin{array}{l}\text { Não } \\
\text { relacionada }\end{array}$ & $\begin{array}{l}\text { Tese defendida na Escola } \\
\text { enfermagem Ana Nery em } \\
2000 \text {. }\end{array}$ \\
\hline 2 & Souza, F. & $\begin{array}{l}\text { A percepção de docentes sobre a } \\
\text { formação moral de alunos de uma Escola } \\
\text { Técnica de Saúde }\end{array}$ & $\begin{array}{l}\text { Não } \\
\text { relacionada }\end{array}$ & $\begin{array}{l}\text { Dissertação defendida na } \\
\text { Escola Nacional de Saúde } \\
\text { Pública Sergio Arouca em } \\
2008 .\end{array}$ \\
\hline 3 & $\begin{array}{l}\text { Pagliuso, L.; Pasian, } \\
\text { S.R. }\end{array}$ & $\begin{array}{l}\text { As figuras complexas de rey: normas } \\
\text { preliminares com crianças de } 9 \text { e } 10 \text { anos }\end{array}$ & $\begin{array}{l}\text { Não } \\
\text { relacionada }\end{array}$ & $\begin{array}{l}\text { Psico (Porto Alegre). Maio-ago } \\
2007 \text {, vol. 38(2), p. 148-156. }\end{array}$ \\
\hline 4 & $\begin{array}{l}\text { Bandeira, D.R.; } \\
\text { Costa, A.; Arteche, } \\
\text { A. }\end{array}$ & $\begin{array}{l}\text { Estudo de validade do DFH como medida } \\
\text { de desenvolvimento cognitivo infantil }\end{array}$ & $\begin{array}{l}\text { Não } \\
\text { relacionada }\end{array}$ & $\begin{array}{l}\text { Psicologia reflexão e crítica. } \\
2008, \text { vol. } 21(2) \text {, p.332-337. }\end{array}$ \\
\hline
\end{tabular}




\begin{tabular}{|c|c|c|c|c|}
\hline 5 & Araújo, A.T. da S. & Redes em psicologia clínica & $\begin{array}{l}\text { Não } \\
\text { relacionada }\end{array}$ & $\begin{array}{l}\text { Psikhe, jul-dez 2002, vol. 7(2), } \\
\text { p. 32-37. }\end{array}$ \\
\hline 6 & $\begin{array}{l}\text { Martins, F.T.M.; } \\
\text { Carvalho, E.C. de. }\end{array}$ & $\begin{array}{l}\text { A percepção do paciente referente a ser } \\
\text { portador de um cateter de longa } \\
\text { permanência }\end{array}$ & $\begin{array}{l}\text { Não } \\
\text { relacionada }\end{array}$ & $\begin{array}{l}\text { Rev. Esc. Enferm. USP, set. } \\
\text { 2008, vol. 42(3), p. 526-531. }\end{array}$ \\
\hline 7 & $\begin{array}{l}\text { Prebianchi, H.B.; } \\
\text { Cury, V.E. }\end{array}$ & $\begin{array}{l}\text { Atendimento infantil numa clínica-escola } \\
\text { de psicologia: percepção dos } \\
\text { profissionais envolvidos }\end{array}$ & $\begin{array}{l}\text { Não } \\
\text { relacionada }\end{array}$ & $\begin{array}{l}\text { Paidéia. Maio-ago. 2005, vol. } \\
\text { 15(31), p. 249-258. }\end{array}$ \\
\hline 8 & $\begin{array}{l}\text { Shimizu, H. E.; } \\
\text { Ciampone, M.H.T. }\end{array}$ & $\begin{array}{l}\text { As representações sociais dos } \\
\text { trabalhadores de enfermagem não } \\
\text { enfermeiros (técnicos e auxiliares de } \\
\text { enfermagem) sobre o trabalho em } \\
\text { Unidade de Terapia Intensiva em um } \\
\text { hospital-escola }\end{array}$ & $\begin{array}{l}\text { Não } \\
\text { relacionada }\end{array}$ & $\begin{array}{l}\text { Rev. Esc. Enferm. USP, jun. } \\
\text { 2002, vol. 36(2), p. 148-155. }\end{array}$ \\
\hline 9 & $\begin{array}{l}\text { Shimizu, A. de M.; } \\
\text { Menin, M. S. de S. }\end{array}$ & $\begin{array}{l}\text { Representações sociais de lei, justiça e } \\
\text { injustiça: uma pesquisa com jovens } \\
\text { argentinos e brasileiros utilizando a } \\
\text { técnica de evocação livre de palavras }\end{array}$ & $\begin{array}{l}\text { Não } \\
\text { relacionada }\end{array}$ & $\begin{array}{l}\text { Estud. Psicol. (Natal). Maio- } \\
\text { ago. 2004, vol. 9(2), p. 239- } \\
247 .\end{array}$ \\
\hline 10 & $\begin{array}{l}\text { Fonseca, A.D. da; } \\
\text { Gomes, V.L. de O. }\end{array}$ & $\begin{array}{l}\text { Manifestações de gênero no processo de } \\
\text { adolescer }\end{array}$ & $\begin{array}{l}\text { Não } \\
\text { relacionada }\end{array}$ & $\begin{array}{l}\text { Acta sci., Health sci. jan.-jun. } \\
\text { 2004, vol. 26(1), p. 231-237. }\end{array}$ \\
\hline 11 & Elali, G.A. & $\begin{array}{l}\text { O ambiente da escola - o ambiente na } \\
\text { escola: uma discussão sobre a relação } \\
\text { escola-natureza em educação infantil }\end{array}$ & $\begin{array}{l}\text { Não } \\
\text { relacionada }\end{array}$ & $\begin{array}{l}\text { Estud. Psicol. (Natal). Maio- } \\
\text { ago. 2003, vol. 8(2), p. 309- } \\
319 .\end{array}$ \\
\hline 12 & $\begin{array}{l}\text { Roazzi, A.; } \\
\text { Federicci, F. C. B; } \\
\text { Wilson, M. }\end{array}$ & $\begin{array}{l}\text { A estrutura primitiva da representação } \\
\text { social do medo }\end{array}$ & $\begin{array}{l}\text { Não } \\
\text { relacionada }\end{array}$ & $\begin{array}{l}\text { Psicologia reflexão e crítica. } \\
2001 \text {, vol. } 14(1) \text {, p. } 57-72 .\end{array}$ \\
\hline 13 & Silva, A.R.B. & $\begin{array}{l}\text { Convivendo com o câncer ginecológico } \\
\text { avançado: em foco a mulher e seus } \\
\text { familiares }\end{array}$ & $\begin{array}{l}\text { Não } \\
\text { relacionada }\end{array}$ & $\begin{array}{l}\text { Tese defendida na Escola de } \\
\text { enfermagem da USP em } 2002 .\end{array}$ \\
\hline 14 & Labate, R.C.; et al. & $\begin{array}{l}\text { Técnica da complementação de frases } \\
\text { como recurso para expressão vivencial } \\
\text { do aluno em véspera de prova }\end{array}$ & $\begin{array}{l}\text { Não } \\
\text { relacionada }\end{array}$ & $\begin{array}{l}\text { Rev. Latinoam. enferm. abr. } \\
\text { 1996, vol. 4(n.esp.), p. 39-49. }\end{array}$ \\
\hline 15 & $\begin{array}{l}\text { Gaiva, M.A.M.; } \\
\text { Ferriani, M. das G.C. }\end{array}$ & $\begin{array}{l}\text { O cotidiano de escolares nascidos pré- } \\
\text { termo: percepção de crianças e } \\
\text { familiares }\end{array}$ & $\begin{array}{l}\text { Não } \\
\text { relacionada }\end{array}$ & $\begin{array}{l}\text { Rev. Bras. crescimento } \\
\text { desenvolv. hum. Jan.-dez. } \\
\text { 1998, vol. 8(1/2), p. 52-63. }\end{array}$ \\
\hline 16 & Pires, D.C.H. & $\begin{array}{l}\text { Eficiência de um modelo triádico no } \\
\text { atendimento psicológico ao } \\
\text { comportamento de agressão em uma } \\
\text { clínica-escola }\end{array}$ & $\begin{array}{l}\text { Não } \\
\text { relacionada }\end{array}$ & $\begin{array}{l}\text { Tese defendida no Instituto de } \\
\text { Psicologia da USP em } 1998 .\end{array}$ \\
\hline 17 & Rodrigues, A. da S. & $\begin{array}{l}\text { Enfermeiros e médicos de unidade de } \\
\text { terapia intensiva e pronto socorro face à } \\
\text { manutenção e notificação de potenciais } \\
\text { doadores de órgãos: crenças e valores }\end{array}$ & $\begin{array}{l}\text { Não } \\
\text { relacionada }\end{array}$ & $\begin{array}{l}\text { Dissertação defendida na } \\
\text { Escola de enfermagem da USP } \\
\text { em } 2001 .\end{array}$ \\
\hline 18 & Gomes, I.C. & $\begin{array}{l}\text { Uma reflexão sobre a influência da } \\
\text { dinâmica do casal, na formação do } \\
\text { sintoma da criança, utilizando-se a } \\
\text { técnica do psicodiagnóstico infantil }\end{array}$ & $\begin{array}{l}\text { Não } \\
\text { relacionada }\end{array}$ & $\begin{array}{l}\text { Tese defendida no Instituto de } \\
\text { Psicologia da USP em } 1997 .\end{array}$ \\
\hline 19 & Carvalho, A.M. & $\begin{array}{l}\text { Comportamento de cuidado entre } \\
\text { crianças: um estudo longitudinal em } \\
\text { diferentes ambientes institucionais }\end{array}$ & $\begin{array}{l}\text { Não } \\
\text { relacionada }\end{array}$ & $\begin{array}{l}\text { Tese defendida no Instituto de } \\
\text { Psicologia da USP em } 1996 .\end{array}$ \\
\hline 20 & Albano, A.A.M. & $\begin{array}{l}\text { Tuneu, Tarsila e outros mestres... uma } \\
\text { história de iniciação }\end{array}$ & $\begin{array}{l}\text { Não } \\
\text { relacionada }\end{array}$ & $\begin{array}{l}\text { Tese defendida no Instituto de } \\
\text { Psicologia da USP em } 1995 .\end{array}$ \\
\hline 21 & $\begin{array}{l}\text { Salvarani, M. de } \\
\text { C.C. }\end{array}$ & $\begin{array}{l}\text { O paciente cirúrgico e suas expectativas } \\
\text { de comunicação com a enfermeira }\end{array}$ & $\begin{array}{l}\text { Não } \\
\text { relacionada }\end{array}$ & $\begin{array}{l}\text { Dissertação defendida na } \\
\text { Escola de Enfermagem de } \\
\text { Ribeirão Preto - USP em } 1991 .\end{array}$ \\
\hline 22 & Castanho, M.I.S. & $\begin{array}{l}\text { Possibilidades e limites de um trabalho } \\
\text { em psicologia escolar: relato de } \\
\text { experiência }\end{array}$ & $\begin{array}{l}\text { Não } \\
\text { relacionada }\end{array}$ & $\begin{array}{l}\text { Dissertação defendida no } \\
\text { Instituto de Psicologia da USP } \\
\text { em } 1990 .\end{array}$ \\
\hline 23 & Oliveira, P. de & $\begin{array}{l}\text { O conto policial e as origens da } \\
\text { psicanálise. }\end{array}$ & $\begin{array}{l}\text { Não } \\
\text { relacionada }\end{array}$ & $\begin{array}{l}\text { Psicol. clin. 2009, vol.21, n. } 1 \text {, } \\
\text { p.119-136. }\end{array}$ \\
\hline 24 & Engel, J.V. & $\begin{array}{l}\text { Sobre o papel da técnica, da supervisão } \\
\text { e da instituição em uma psicoterapia } \\
\text { breve de grupo }\end{array}$ & $\begin{array}{l}\text { Não } \\
\text { relacionada }\end{array}$ & $\begin{array}{l}\text { J. bras. psiquiatr. Jul-ago. } \\
1985 \text {, vol. } 34(4) \text {, p. 211-216. }\end{array}$ \\
\hline 25 & Andreoli, S.B.; et al. & $\begin{array}{l}\text { Estrutura fatorial do questionário de } \\
\text { morbidade psiquiátrica de adultos } \\
\text { aplicado em amostras populacionais de } \\
\text { cidades brasileiras }\end{array}$ & $\begin{array}{l}\text { Não } \\
\text { relacionada }\end{array}$ & $\begin{array}{l}\text { Rev. Saúde Pública. Ago. } \\
\text { 1994, vol. 28, n. 4, p.249-260. }\end{array}$ \\
\hline 26 & $\begin{array}{l}\text { Vasconcellos-Silva, } \\
\text { P.R.; Nolasco, P.T. } \\
\text { de L. }\end{array}$ & $\begin{array}{l}\text { Dialética da autonomia dos equilíbrios } \\
\text { nos conflitos entre pacientes e cirurgiões } \\
\text { oncológicos }\end{array}$ & $\begin{array}{l}\text { Não } \\
\text { relacionada }\end{array}$ & $\begin{array}{l}\text { Rev. Saúde Pública. Out. 2009, } \\
\text { vol. 43, n.5, p.839-845. }\end{array}$ \\
\hline 27 & Souza, N.L. de; et al. & $\begin{array}{l}\text { Percepção materna com o nascimento } \\
\text { prematuro e vivência da gravidez com } \\
\text { pré-eclampsia }\end{array}$ & $\begin{array}{l}\text { Não } \\
\text { relacionada }\end{array}$ & $\begin{array}{l}\text { Rev. Saúde Pública. Out. 2007, } \\
\text { vol. 41, n.5, p.704-710. }\end{array}$ \\
\hline
\end{tabular}




\begin{tabular}{|c|c|c|c|c|}
\hline 28 & Soldera, M.; et al. & $\begin{array}{l}\text { Uso de drogas psicotrópicas por } \\
\text { estudantes: prevalência e fatores sociais } \\
\text { associados }\end{array}$ & $\begin{array}{l}\text { Não } \\
\text { relacionada }\end{array}$ & $\begin{array}{l}\text { Rev. Saúde Pública. Abr. 2004, } \\
\text { vol. 38, n. 2, p.277-283. }\end{array}$ \\
\hline 29 & Elias, A.C.A.; et al. & $\begin{array}{l}\text { Programa de treinamento sobre a } \\
\text { intervenção terapêutica "relaxamento, } \\
\text { imagens mentais e espiritualidade" } \\
\text { (RIME) para re-significar a dor espiritual } \\
\text { de pacientes terminais. }\end{array}$ & $\begin{array}{l}\text { Não } \\
\text { relacionada }\end{array}$ & $\begin{array}{l}\text { Rev. psiquiatr. Clín. 2007, vol. } \\
\text { 34, suppl. 1, p.60-72. }\end{array}$ \\
\hline 30 & $\begin{array}{l}\text { Aragaki, I.M.M., } \\
\text { Silva, I.A.; Santos, } \\
\text { J.L.F. dos }\end{array}$ & $\begin{array}{l}\text { Traço e estado de ansiedade de nutrizes } \\
\text { com indicadores de hipogalactia e } \\
\text { nutrizes com galactia normal }\end{array}$ & $\begin{array}{l}\text { Não } \\
\text { relacionada }\end{array}$ & $\begin{array}{l}\text { Rev. esc. Enferm. USP. Set. } \\
\text { 2006, vol. 40, n. 3, p.396-403. }\end{array}$ \\
\hline 31 & $\begin{array}{l}\text { Moreira, A.S.P., } \\
\text { Rodrigues, R.A.P.; } \\
\text { Manzolli, M.C. }\end{array}$ & $\begin{array}{l}\text { Transições relatadas por mulher adulta: } \\
\text { subsídios ao modelo de adaptação } \\
\text { humana de Schlossberg }\end{array}$ & $\begin{array}{l}\text { Não } \\
\text { relacionada }\end{array}$ & $\begin{array}{l}\text { Rev. Latino-Am. Enfermagem. } \\
\text { Jan. 1996, vol. 4, n.1, p.177- } \\
\text { 187. }\end{array}$ \\
\hline 32 & $\begin{array}{l}\text { Lima, R.C. de; } \\
\text { Brêtas, J.R. da S. }\end{array}$ & $\begin{array}{l}\text { Estudo comparativo entre séries de } \\
\text { graduação em enfermagem: } \\
\text { representações dos cuidados ao corpo } \\
\text { do cliente }\end{array}$ & $\begin{array}{l}\text { Não } \\
\text { relacionada }\end{array}$ & $\begin{array}{l}\text { Acta Paul. Enferm. Dez. 2006, } \\
\text { vol. 19, n. 4, p.379-386. }\end{array}$ \\
\hline 33 & Marques, S.L.; et al. & $\begin{array}{l}\text { Fidedignidade do sistema Goodenough } \\
\text { de avaliação cognitiva: uma visão do } \\
\text { contexto atual }\end{array}$ & $\begin{array}{l}\text { Não } \\
\text { relacionada }\end{array}$ & $\begin{array}{l}\text { Estud. Psicol. (Natal). Jan. } \\
\text { 2002, vol. 7, n. 1, p.57-64. }\end{array}$ \\
\hline 34 & Sarriera, J. C.; et al. & $\begin{array}{l}\text { Formação da identidade ocupacional em } \\
\text { adolescentes }\end{array}$ & $\begin{array}{l}\text { Não } \\
\text { relacionada }\end{array}$ & $\begin{array}{l}\text { Estud. Psicol. (Natal). Jun. } \\
\text { 2001, vol. 6, n. 1, p.27-32. }\end{array}$ \\
\hline 35 & $\begin{array}{l}\text { Marco, M.A. de; et } \\
\text { al. }\end{array}$ & $\begin{array}{l}\text { Laboratório de comunicação: ampliando } \\
\text { as habilidades do estudante de medicina } \\
\text { para a prática da entrevista }\end{array}$ & $\begin{array}{l}\text { Não } \\
\text { relacionada }\end{array}$ & $\begin{array}{l}\text { Interface (Botucatu). Mar. } \\
2010 \text {, vol. 14, n.32, p.217-227. }\end{array}$ \\
\hline 36 & Soldera, M.; et al. & $\begin{array}{l}\text { Uso pesado de álcool por estudantes dos } \\
\text { ensinos fundamental e médio de escolas } \\
\text { centrais e periféricas de Campinas (SP): } \\
\text { prevalência e fatores associados. }\end{array}$ & $\begin{array}{l}\text { Não } \\
\text { relacionada }\end{array}$ & $\begin{array}{l}\text { Rev. Brás. Psiquiatr. Set. 2004, } \\
\text { vol. 26, n. 3, p.174-179. }\end{array}$ \\
\hline 37 & $\begin{array}{l}\text { Nosow, V.; Peniche, } \\
\text { A. de C.G. }\end{array}$ & $\begin{array}{l}\text { Paciente cirúrgico ambulatorial: calatonia } \\
\text { e ansiedade }\end{array}$ & $\begin{array}{l}\text { Não } \\
\text { relacionada }\end{array}$ & $\begin{array}{l}\text { Acta Paul. Enferm. Jun. 2007, } \\
\text { vol. 20, n. 2, p.161-167. }\end{array}$ \\
\hline 38 & BVS-Psi & Biografia de Oswaldo de Barros Santos & Relacionada & $\begin{array}{l}\text { Dicionário biográfico da } \\
\text { psicologia no Brasil. Disponível } \\
\text { em: http://www.bvs-psi.org.br/ }\end{array}$ \\
\hline
\end{tabular}

Termos-chave: (educação profissional\$) psicologia

\begin{tabular}{|c|c|c|c|c|}
\hline № & Autor & Título & $\begin{array}{l}\text { Relação com } \\
\text { o tema }\end{array}$ & Publicado em \\
\hline 1 & $\begin{array}{l}\text { Escola Politécnica } \\
\text { de Saúde Joaquim } \\
\text { Venâncio }\end{array}$ & $\begin{array}{l}\text { Iniciação científica na educação } \\
\text { profissional em saúde: articulando } \\
\text { trabalho, ciência e cultura }\end{array}$ & $\begin{array}{l}\text { Não } \\
\text { relacionada }\end{array}$ & Rio de Janeiro: EPSJV; 2008. \\
\hline 2 & Winkler, M.I.; et al. & $\begin{array}{l}\text { Cuando el bienestar psicológico está en } \\
\text { juego: la dimensión ética en la formación } \\
\text { profesional de psicólogos y psicólogas en } \\
\text { Chile }\end{array}$ & $\begin{array}{l}\text { Não } \\
\text { relacionada }\end{array}$ & $\begin{array}{l}\text { Ter. psicol. Jun. 2007, vol. } \\
25(1) \text {, p. 5-24. }\end{array}$ \\
\hline 3 & Falcone, R. & $\begin{array}{l}\text { Psicología preprofesional en Argentina: } \\
\text { algunos resultados del relevamiento de } \\
\text { antecedentes de formación en el área } \\
\text { assistencial }\end{array}$ & $\begin{array}{l}\text { Não } \\
\text { relacionada }\end{array}$ & $\begin{array}{l}\text { Investig. Psicol. 2004, vol. 9(2), } \\
\text { p. 93-110. }\end{array}$ \\
\hline 4 & Castro Solano, A. & $\begin{array}{l}\text { Las competencias profesionales del } \\
\text { psicólogo y las necesidades de perfiles } \\
\text { profesionales en los diferentes ámbitos } \\
\text { laborales }\end{array}$ & $\begin{array}{l}\text { Não } \\
\text { relacionada }\end{array}$ & $\begin{array}{l}\text { Interdisciplinaria. } 2004 \text {, vol. } \\
21(2), \text { p. 117-152. }\end{array}$ \\
\hline 5 & Ferrero, $\mathrm{A}$. & $\begin{array}{l}\text { El lugar de la ética en la universidad: la } \\
\text { docencia universitaria como práctica de } \\
\text { formación ciudadana }\end{array}$ & $\begin{array}{l}\text { Não } \\
\text { relacionada }\end{array}$ & $\begin{array}{l}\text { Perspect. psicol. 2005, vol. } \\
2(1), \text { p. } 76-78 .\end{array}$ \\
\hline 6 & $\begin{array}{l}\text { Gorayeb, R.; } \\
\text { Guerrelhas, F. }\end{array}$ & $\begin{array}{l}\text { Sistematização da prática psicológica em } \\
\text { ambientes médicos }\end{array}$ & $\begin{array}{l}\text { Não } \\
\text { relacionada }\end{array}$ & $\begin{array}{l}\text { Rev. bras. ter. comport. cogn. } \\
\text { Jan.-jun. 2003, vol. 5(1), p. } 11- \\
19 .\end{array}$ \\
\hline 7 & Aisenson, D.; et al. & $\begin{array}{l}\text { Representaciones de estudiantes y } \\
\text { graduados recientes sobre la carrera y la } \\
\text { profesión del psicólogo }\end{array}$ & $\begin{array}{l}\text { Não } \\
\text { relacionada }\end{array}$ & $\begin{array}{l}\text { Anu. investig. - Fac. Psicol., } \\
\text { Univ. B. Aires. Set. 2005, vol. } \\
12, \text { p. 35-42. }\end{array}$ \\
\hline 8 & Jenkins, C. D. & $\begin{array}{l}\text { Mejoremos la salud a todas las edades: } \\
\text { un manual para el cambio de } \\
\text { comportamento }\end{array}$ & $\begin{array}{l}\text { Não } \\
\text { relacionada }\end{array}$ & $\begin{array}{l}\text { Washington, D.C; Organización } \\
\text { Panamericana de la Salud. } \\
2005 .\end{array}$ \\
\hline 9 & $\begin{array}{l}\text { López Lanos, R.; } \\
\text { Mamani, B. }\end{array}$ & $\begin{array}{l}\text { Rendimiento académico y su relación con } \\
\text { las características sociales del estudiante } \\
\text { en la carrera de nutrición y dietética de la } \\
\text { Facultad de Medicina gestión } 1994 \text { a } 1998\end{array}$ & $\begin{array}{l}\text { Não } \\
\text { relacionada }\end{array}$ & $\begin{array}{l}\text { Cuad. Hosp. Clín. 2004, vol. } \\
\text { 49(2), p. 147-154. }\end{array}$ \\
\hline
\end{tabular}




\begin{tabular}{|c|c|c|c|c|}
\hline 10 & $\begin{array}{l}\text { González } \\
\text { Menéndez, R. }\end{array}$ & $\begin{array}{l}\text { La relación médico-paciente y su } \\
\text { significado en la formación profesional }\end{array}$ & $\begin{array}{l}\text { Não } \\
\text { relacionada }\end{array}$ & $\begin{array}{l}\text { Educ. med. super. Out.-dez. } \\
\text { 2003, vol. } 17(4) .\end{array}$ \\
\hline 11 & Jenkins, C. D. & $\begin{array}{l}\text { Building better health: a handbook of } \\
\text { behavioral change }\end{array}$ & $\begin{array}{l}\text { Não } \\
\text { relacionada }\end{array}$ & $\begin{array}{l}\text { Washington, D.C; Pan } \\
\text { Américan Health Organization. } \\
2003 .\end{array}$ \\
\hline 12 & $\begin{array}{l}\text { Carrilo, C.M.; Tapi, } \\
\text { H.E.; Castillo, L. }\end{array}$ & $\begin{array}{l}\text { Actividades que cumplen las Enfermeras } \\
\text { que laboran en Instituciones Educativas } \\
\text { de Nivel Primario y Secundario de la } \\
\text { Ciudad de Quito }\end{array}$ & $\begin{array}{l}\text { Não } \\
\text { relacionada }\end{array}$ & $\begin{array}{l}\text { Quito: Escuela Nacional de } \\
\text { Enfermería. abr. } 1982 .\end{array}$ \\
\hline 13 & Marcos, S. & $\begin{array}{l}\text { Estudio descriptivo acerca del accionar del } \\
\text { profesional fonoaudiologo desde el area } \\
\text { de la prevencion en el ambito educativo, } \\
\text { en la ciudad de Pergamino, en el año } \\
2000\end{array}$ & $\begin{array}{l}\text { Não } \\
\text { relacionada }\end{array}$ & Rosario; s.n; 2001. \\
\hline 14 & Piacente, $\mathrm{T}$. & $\begin{array}{l}\text { Psicoanálisis y formación académica en } \\
\text { psicologia }\end{array}$ & $\begin{array}{l}\text { Não } \\
\text { relacionada }\end{array}$ & $\begin{array}{l}\text { Acta psiquiátr. psicol. Am. Lat. } \\
\text { Set. 1998, vol. 44(3), p.278-84. }\end{array}$ \\
\hline 15 & $\begin{array}{l}\text { Castillo Sánchez, } \\
\text { E. J.; et al. }\end{array}$ & $\begin{array}{l}\text { Ambiente educativo en medicina: } \\
\text { propuesta de un instrumento de } \\
\text { evaluación }\end{array}$ & $\begin{array}{l}\text { Não } \\
\text { relacionada }\end{array}$ & $\begin{array}{l}\text { Rev. méd. IMSS. Set.-out. } \\
\text { 2001, vol. 39(5), p. 403-407. }\end{array}$ \\
\hline 16 & Gentile, A. S. & $\begin{array}{l}\text { Las psicociencias en Rosario entre } 1920 \text { y } \\
1960\end{array}$ & $\begin{array}{l}\text { Não } \\
\text { relacionada }\end{array}$ & $\begin{array}{l}\text { Acta psiquiátr. psicol. Am. Lat. } \\
\text { Mar. 1998, vol. 44(1), p.69-79. }\end{array}$ \\
\hline 17 & $\begin{array}{l}\text { Perú. Ministerio de } \\
\text { Salud }\end{array}$ & $\begin{array}{l}\text { Curso de alta especialización en } \\
\text { fármacodependencia: informe final }\end{array}$ & $\begin{array}{l}\text { Não } \\
\text { relacionada }\end{array}$ & $\begin{array}{l}\text { Instituto Nacional de Salud } \\
\text { Mental Honorio Delgado- } \\
\text { Hideyo Noguchi. 1989. }\end{array}$ \\
\hline
\end{tabular}

Com os termos-chave (educação tecnica) psicologia; (escola profissional\$) psicologia; (ensino profissional\$) psicologia: não se obteve nenhum resultado diferente dos já elencados.

\section{Resultado da busca por meio da Biblioteca Digital de Teses e Dissertações Nacional}

Termos-chave: "escola profissional" e psicologia

\begin{tabular}{|c|c|c|c|c|}
\hline No. & Autor & Título & $\begin{array}{l}\text { Relação } \\
\text { com o tema }\end{array}$ & Publicado em \\
\hline 1 & $\begin{array}{l}\text { Gomes, } \\
\text { S.S. de } \\
\text { C.R. }\end{array}$ & $\begin{array}{l}\text { Inclusão digital de jovens e adultos: A } \\
\text { alfabetização digital de adultos do curso de } \\
\text { informática do Centro Municipal de } \\
\text { capacitação e treinamento }\end{array}$ & $\begin{array}{l}\text { Não } \\
\text { relacionada }\end{array}$ & $\begin{array}{l}\text { Dissertação defendida no Mackenzie } \\
\text { em 2006. Disponível em: } \\
\text { http://mx.mackenzie.com.br/tede/tde_b } \\
\text { usca/arquivo.php?codArquivo=1519 }\end{array}$ \\
\hline 2 & Zorzal, M.F. & $\begin{array}{l}\text { O discurso da competência para o trabalho } \\
\text { e a educação em tempos neoliberais: a } \\
\text { história reeditada como farsa }\end{array}$ & $\begin{array}{l}\text { Não } \\
\text { relacionada }\end{array}$ & $\begin{array}{l}\text { Tese defendida na Universidade } \\
\text { Federal de São Carlos em } 2006 . \\
\text { Disponível em: } \\
\text { http://www.bdtd.ufscar.br/htdocs/tedeSi } \\
\text { mplificado//tde_busca/arquivo.php?cod } \\
\text { Arquivo=1147 }\end{array}$ \\
\hline
\end{tabular}

Termos-chave: "educação profissional" e psicologia

\begin{tabular}{|c|c|c|c|c|}
\hline № & Autor & Título & $\begin{array}{l}\text { Relação } \\
\text { com o tema }\end{array}$ & Publicado em \\
\hline 1 & Pires, F.H. & $\begin{array}{l}\text { O ensino de psicologia na educação } \\
\text { profissional: (des) compromissos } \\
\text { docentes com a saúde }\end{array}$ & $\begin{array}{l}\text { Muito } \\
\text { relacionada }\end{array}$ & $\begin{array}{l}\text { Dissertação defendida na UFRGS } \\
\text { em 2009. Disponível em: } \\
\text { http://www.lume.ufrgs.br/handle/1018 } \\
\text { 3/18259 }\end{array}$ \\
\hline 2 & Zulke, M.I. U. & $\begin{array}{l}\text { A Reforma do estado e os processos de } \\
\text { subjetivação: um estudo sobre o } \\
\text { trabalho do servidor público em } \\
\text { instituição de educação profissional }\end{array}$ & Relacionada & $\begin{array}{l}\text { Dissertação defendida na UFRGS } \\
\text { em } 2007 \text {. Disponível em: } \\
\text { http://www.lume.ufrgs.br/handle/1018 } \\
3 / 13410\end{array}$ \\
\hline 3 & Lemos, L. S. & $\begin{array}{l}\text { A identidade do licenciado em psicologia } \\
\text { (uma análise das regulamentações } \\
\text { brasileiras entre } 1962 \text { e } 2007\end{array}$ & Relacionada & $\begin{array}{l}\text { Dissertação defendida na UFMG em } \\
\text { 2009. Disponível em: } \\
\text { http://dspace.lcc.ufmg.br/dspace/han } \\
\text { dle/1843/IOMS-7LRGMN }\end{array}$ \\
\hline 4 & $\begin{array}{l}\text { Soléra, M. de } \\
\text { C.O.G. }\end{array}$ & $\begin{array}{l}\text { É possível a inclusão? Um estudo sobre } \\
\text { as dificuldades da relação do sujeito } \\
\text { com a diferença }\end{array}$ & $\begin{array}{l}\text { Não } \\
\text { relacionada }\end{array}$ & $\begin{array}{l}\text { Dissertação defendida no Instituto de } \\
\text { Psicologia - USP em } 2008 . \\
\text { Disponível em: } \\
\text { http://www.teses.usp.br/teses/disponi } \\
\text { veis/47/47133/tde-16122008-153306/ }\end{array}$ \\
\hline
\end{tabular}




\begin{tabular}{llll}
\hline 5 & Zimmermann, A. & A escolha profissional na área da saúde: \\
a opção pela enfermagem & & $\begin{array}{l}\text { Não } \\
\text { relacionada }\end{array}$ & $\begin{array}{l}\text { Dissertação defendida na Unicamp } \\
\text { em 2007. Disponível em: } \\
\text { http://libdigi.unicamp.br/document/?c } \\
\text { ode=vtls000416627 }\end{array}$
\end{tabular}

Termos-chave: "ensino profissional" e psicologia

\begin{tabular}{|c|c|c|c|c|}
\hline № & Autor & Título & $\begin{array}{l}\text { Relação com } \\
\text { o tema }\end{array}$ & Publicado em \\
\hline 1 & $\begin{array}{l}\text { Rocha, P.A. } \\
\text { da S. }\end{array}$ & $\begin{array}{l}\text { O SENAI na constituição de identidade } \\
\text { de seus alunos: um estudo sobre } \\
\text { egressos que se tornaram instrutores }\end{array}$ & Relacionada & $\begin{array}{l}\text { Tese defendida na PUC-SP em } 2005 . \\
\text { Disponível em: } \\
\text { http://www.bdae.org.br/dspace/bitstrea } \\
\text { m/123456789/1918/1/tese.pdf }\end{array}$ \\
\hline 2 & $\begin{array}{l}\text { Lima, A. P. } \\
\text { de }\end{array}$ & $\begin{array}{l}\text { Visitas técnicas: um processo de } \\
\text { conciliação escola - empresa }\end{array}$ & $\begin{array}{l}\text { Não } \\
\text { relacionada }\end{array}$ & $\begin{array}{l}\text { Tese defendida na PUC-SP em } 2008 . \\
\text { Disponível em: } \\
\text { http://www.sapientia.pucsp.br//tde_busc } \\
\text { a/arquivo.php?codArquivo=8026 }\end{array}$ \\
\hline 3 & Castioni, R. & $\begin{array}{l}\text { Da qualificação a competência: dos } \\
\text { fundamentos aos usos - O Planfor } \\
\text { como dissumulador de novos conceitos } \\
\text { em educação }\end{array}$ & $\begin{array}{l}\text { Não } \\
\text { relacionada }\end{array}$ & $\begin{array}{l}\text { Tese defendida na Unicamp em } 2002 . \\
\text { Disponível em: } \\
\text { http://libdigi.unicamp.br/document/?cod } \\
\text { e=vtls000278417 }\end{array}$ \\
\hline
\end{tabular}

$\frac{\text { Termos-chave: "escola técnica" e psicologia }}{\text { T№ }}$

\begin{tabular}{|c|c|c|c|c|}
\hline № & Autor & Título & $\begin{array}{l}\text { Relação com } \\
\text { o tema }\end{array}$ & Publicado em \\
\hline 1 & $\begin{array}{l}\text { Moreira, M. da } \\
\text { G. L. }\end{array}$ & $\begin{array}{l}\text { Os aspectos psicológicos envolvidos no } \\
\text { processo inclusivo: uma análise do projeto } \\
\text { educar na escola técnica tupy }\end{array}$ & $\begin{array}{l}\text { Não } \\
\text { relacionada }\end{array}$ & $\begin{array}{l}\text { Dissertação defendida na } \\
\text { Universidade do Estado de Santa } \\
\text { Catarina em 2005. Disponível em: } \\
\text { http://www.tede.udesc.br/tde_busc } \\
\text { a/arquivo.php?codArquivo=384 }\end{array}$ \\
\hline 2 & Silva, J. L. da & $\begin{array}{l}\text { Os mecanismos de coesão no anúncio } \\
\text { publicitário da enciclopédia bohemia }\end{array}$ & $\begin{array}{l}\text { Não } \\
\text { relacionada }\end{array}$ & $\begin{array}{l}\text { Dissertação defendida no } \\
\text { Mackenzie em 2007. Disponível } \\
\text { em: } \\
\text { http://mx.mackenzie.com.br/tede/t } \\
\text { de_busca/arquivo.php?codArquivo } \\
=288\end{array}$ \\
\hline 3 & Pinto, U. R. & $\begin{array}{l}\text { A temática ambiental em escola técnica de } \\
\text { nível médio: reflexões a partir do programa de } \\
\text { educação ambiental do CEFET-SP }\end{array}$ & $\begin{array}{l}\text { Não } \\
\text { relacionada }\end{array}$ & $\begin{array}{l}\text { Dissertação defendida no } \\
\text { Mackenzie em 2009. Disponível } \\
\text { em: } \\
\text { http://mx.mackenzie.com.br/tede/t } \\
\text { de_busca/arquivo.php?codArquivo } \\
=1519\end{array}$ \\
\hline
\end{tabular}

Termos-chave: "ensino tecnico" e psicologia

\begin{tabular}{|c|c|c|c|c|}
\hline № & Autor & Título & $\begin{array}{l}\text { Relação com } \\
\text { o tema }\end{array}$ & Publicado em \\
\hline 1 & $\begin{array}{l}\text { Maciel, } \\
\text { M.S. }\end{array}$ & $\begin{array}{l}\text { Cursos técnicos: um campo de atuação } \\
\text { para o licenciado em psicologia na cidade } \\
\text { de } \mathrm{BH}\end{array}$ & $\begin{array}{l}\text { Muito } \\
\text { relacionada }\end{array}$ & $\begin{array}{l}\text { Dissertação defendida na UFMG em } \\
\text { 2009. Disponível em: } \\
\text { http://bdtdj.ibict.br/executarAcao.jsp?codA } \\
\text { cao=3\&codTd=203291\&url=http://hdl.hand } \\
\text { le.net/1843/FAEC-83UMR5 }\end{array}$ \\
\hline 2 & $\begin{array}{l}\text { Jordão, } \\
\text { T.C. }\end{array}$ & $\begin{array}{l}\text { Formação de professores para o uso da } \\
\text { comunicação digital por meio do trabalho } \\
\text { em parceria }\end{array}$ & $\begin{array}{l}\text { Não } \\
\text { relacionada }\end{array}$ & $\begin{array}{l}\text { Dissertação defendida no Mackenzie em } \\
\text { 2007. Disponível em: } \\
\text { http://mx.mackenzie.com.br/tede/tde_busc } \\
\text { a/arquivo.php?codArquivo=788 }\end{array}$ \\
\hline
\end{tabular}

Com os termos-chave: "educação técnica" e psicologia não se obteve nenhum resultado diferente dos já elencados. 
APÊNDICE B - Quadro contendo cursos atualmente oferecidos nas Etecs, número de discentes e disciplinas que podem ser ministradas pelo licenciado em Psicologia por curso. (continua)

\begin{tabular}{|c|c|c|c|}
\hline Classificação & Curso técnico & Discentes & $\begin{array}{r}\text { Disciplinas que licenciado em } \\
\text { Psicologia pode ministrar }\end{array}$ \\
\hline 1 & Administração & 26.141 & 4 \\
\hline 2 & Informática & 16.732 & 1 \\
\hline 3 & Logística & 10.921 & 1 \\
\hline 4 & Contabilidade & 8.023 & 1 \\
\hline 5 & Enfermagem & 5.964 & 0 \\
\hline 6 & Mecânica & 5.560 & 0 \\
\hline 7 & Nutrição e Dietética & 5.543 & 1 \\
\hline 8 & Eletrônica & 5.305 & 1 \\
\hline 9 & Secretariado & 4.037 & 2 \\
\hline 10 & Química & 3.835 & 1 \\
\hline 11 & Informática para Internet & 3.765 & 1 \\
\hline 12 & Segurança do Trabalho & 3.639 & 2 \\
\hline 13 & Mecatrônica & 3.360 & 1 \\
\hline 14 & Edificações & 3.355 & 1 \\
\hline 15 & Meio Ambiente & 3.128 & 1 \\
\hline 16 & Eletrotécnica & 3.070 & 1 \\
\hline 17 & Marketing & 2.124 & 3 \\
\hline 18 & Técnico Jurídico & 2.095 & 1 \\
\hline 19 & Agropecuária (Integrado) & 1.979 & 1 \\
\hline 20 & Automação Industrial & 1.968 & 1 \\
\hline 21 & Comércio & 1.719 & 2 \\
\hline 22 & Agropecuária & 1.625 & 1 \\
\hline 23 & Design de Interiores & 1.509 & 0 \\
\hline 24 & Açúcar e Álcool & 1.472 & \\
\hline 25 & Gestão de Pequenas Empresas - Telecurso TEC & 1.412 & curso não existia na época da pesquisa \\
\hline 26 & Comunicação Visual & 1.302 & 0 \\
\hline 27 & Secretariado e Assessoria - Telecurso TEC & 1.253 & curso não existia na época da pesquisa \\
\hline 28 & Turismo Receptivo & 1.118 & 1 \\
\hline 29 & Alimentos & 1.094 & 1 \\
\hline 30 & Agenciamento de Viagem & 1.083 & 2 \\
\hline 31 & Redes de Computadores & 1.013 & 0 \\
\hline 32 & Farmácia & 892 & 2 \\
\hline 33 & Administração Empresarial - Telecurso TEC & 872 & curso não existia na época da pesquisa \\
\hline 34 & Hospedagem & 827 & 1 \\
\hline 35 & Desenho de Construção Civil & 681 & 1 \\
\hline 36 & Transações Imobiliárias & 561 & 1 \\
\hline 37 & Modelagem de Vestuário & 560 & 1 \\
\hline 38 & Instrumentação e Equipamentos Industriais & 556 & 1 \\
\hline 39 & Telecomunicações & 514 & 0 \\
\hline 40 & Produção Agropecuária & 504 & 1 \\
\hline 41 & Agroindústria & 484 & 1 \\
\hline 42 & Eletroeletrônica & 462 & 1 \\
\hline 43 & Mecânica-Projetos & 461 & 1 \\
\hline 44 & Metalurgia & 410 & 1 \\
\hline 45 & Agronegócio & 396 & 1 \\
\hline 46 & Cozinha & 391 & 1 \\
\hline 47 & Eventos & 380 & curso não existia na época da pesquisa \\
\hline 48 & Manutenção Automotiva & 353 & 1 \\
\hline
\end{tabular}


Quadro contendo cursos atualmente oferecidos nas Etecs, número de discentes e disciplinas que podem ser ministradas pelo licenciado em Psicologia por curso. (conclusão)

\begin{tabular}{|c|c|c|c|}
\hline Classificação & Curso técnico & Discentes & $\begin{array}{l}\text { Disciplinas que licenciado em } \\
\text { Psicologia pode ministrar }\end{array}$ \\
\hline 49 & Bioquímica & 343 & 0 \\
\hline 50 & Produção de Cana de Açúcar & 337 & 1 \\
\hline 51 & Agrimensura & 333 & 1 \\
\hline 52 & Florestas & 299 & 1 \\
\hline 53 & Análise e Produção de Açúcar e Álcool & 287 & 1 \\
\hline 54 & Saneamento & 285 & 1 \\
\hline 55 & Agroecologia & 277 & 0 \\
\hline 56 & Agente Comunitário de Saúde & 262 & 2 \\
\hline 57 & Eletromecânica & 238 & 1 \\
\hline 58 & Administração - PROEJA & 206 & curso não existia na época da pesquisa \\
\hline 59 & Design de Móveis & 177 & 2 \\
\hline 60 & Manutenção de Aeronaves & 170 & 1 \\
\hline 61 & Canto & 159 & não tinha matriz curricular disponível \\
\hline 62 & Gestão Pública & 152 & curso não existia na época da pesquisa \\
\hline 63 & Prótese Dentária & 148 & 1 \\
\hline 64 & Manutenção e Suporte em Informática & 136 & curso não existia na época da pesquisa \\
\hline 65 & Mineração & 112 & 1 \\
\hline 66 & Dança & 101 & 1 \\
\hline 67 & Seguros & 100 & 1 \\
\hline 68 & Museu & 87 & 1 \\
\hline 69 & Tecelagem & 83 & 1 \\
\hline 70 & Cafeicultura & 78 & 1 \\
\hline 71 & Manutenção de Equipamentos Fora de Estrada & 75 & 1 \\
\hline 72 & Gestão da Produção de Enxovais e Decoração & 75 & 2 \\
\hline 73 & Industrial Madeireiro & 69 & 1 \\
\hline 74 & Regência & 68 & não tinha matriz curricular disponível \\
\hline 75 & Música & 60 & 1 \\
\hline 76 & Processamento de Carnes & 59 & 1 \\
\hline 77 & Curtimento & 56 & 1 \\
\hline 78 & Mecatrônica (Integrado) & 40 & 1 \\
\hline 79 & Hidrologia & 35 & 1 \\
\hline 80 & Agricultura Familiar (Fic) & 35 & curso não existia na época da pesquisa \\
\hline 81 & Avicultura & 35 & curso não existia na época da pesquisa \\
\hline 82 & Agropecuária (Aproveitamento de Estudos) & 34 & 1 \\
\hline 83 & Processos Fotográficos & 33 & curso não existia na época da pesquisa \\
\hline 84 & Paisagismo & 32 & 2 \\
\hline 85 & Lazer & 31 & curso não existia na época da pesquisa \\
\hline 86 & Saúde Bucal & 30 & 2 \\
\hline 87 & Transporte Rodoviário & 27 & curso não existia na época da pesquisa \\
\hline 88 & Desenvolvimento e Produção Mainframe & 23 & curso não existia na época da pesquisa \\
\hline 89 & Agricultura & 23 & 1 \\
\hline 90 & Zootecnia & 22 & curso não existia na época da pesquisa \\
\hline 91 & Cuidador de Idosos & 21 & curso não existia na época da pesquisa \\
\hline 92 & Transporte Ferroviário & 21 & 0 \\
\hline 93 & Calçados Integrado ao Ensino Médio (EJA) & 17 & curso não existia na época da pesquisa \\
\hline
\end{tabular}


APÊNDICE C - Carta de autorização para a realização de pesquisa

Prezada diretora

Eu, Angelina Pandita Pereira, mestranda do Programa de Pós-Graduação do Instituto de Psicologia da Universidade de São Paulo, sob orientação da Prof. Dra. Marie Claire Sekkel, solicito autorização para realização de minha pesquisa de mestrado na Escola Técnica Estadual

A pesquisa intitulada "Contribuições do ensino de psicologia à formação de discentes da educação profissional técnica de nível médio" tem como objetivo estudar as possíveis contribuições do ensino de psicologia à formação de discentes da educação profissional técnica de nível médio. Pretendo realizar a pesquisa principalmente por meio de observação das aulas de Psicologia Organizacional (curso de Administração); Psicologia Comportamental e Psicologia Social (curso de Marketing). Tais observações serão complementadas por observações nos espaços comuns da escola enquanto estiver circulando pelos mesmos, por análise de documentos que sejam referência para a atuação docente, e por conversas formais e informais com docentes e discentes das disciplinas observadas, bem como de outros funcionários da escola que quiserem contribuir para a pesquisa. Farei uso de diário de campo para tomar notas durante as observações, e as conversas formais poderão ou não ser gravadas em áudio, de acordo com a preferência dos participantes. Todo o material obtido durante a pesquisa será analisado em seu conjunto, e tanto o diário de campo quanto as possíveis conversas gravadas serão armazenadas em local reservado. Garanto o sigilo absoluto sobre o nome dos sujeitos que foram observados ou que concederam as conversas formais ou informais. A participação da instituição e de todos os que vierem a se envolver com a pesquisa é voluntária e pode ser interrompida a qualquer momento do estudo sem prejuízo algum aos mesmos. Solicito autorização para a identificação do nome desta instituição na pesquisa, bem como descrição de seu funcionamento. A divulgação futura dos resultados terá finalidade acadêmica, em meios impressos e / ou eletrônicos, no sentido de contribuir para um maior conhecimento do tema estudado, bem como para a formação de professores de psicologia.

\section{TERMO DE CONSENTIMENTO LIVRE E ESCLARECIDO}

Pelo presente instrumento, que atende as exigências legais, a senhora diretora da Escola Técnica

Estadual após a leitura da Carta de autorização para realização de pesquisa, ciente dos procedimentos propostos, não restando quaisquer dúvidas a respeito do lido e explicado, firma seu Consentimento Livre e Esclarecido quanto à realização da pesquisa. Fica claro que a instituição, através de seu representante legal, pode, a qualquer momento, deixar de participar do estudo alvo da pesquisa, sendo que todo o trabalho realizado torna-se confidencial, guardado por força do sigilo profissional.

São Paulo, de de 2010. 
APÊNDICE D - Termo de consentimento livre e esclarecido

TERMO DE CONSENTIMENTO LIVRE E ESCLARECIDO

Meu nome é Angelina Pandita Pereira, sou licenciada em psicologia e psicóloga, estudante do curso de mestrado do Instituto de Psicologia da Universidade de São Paulo.

Realizo uma pesquisa intitulada "Contribuições do ensino de psicologia à formação de discentes da educação profissional técnica de nível médio", a qual tem como objetivo estudar as possíveis contribuições do ensino de psicologia à formação de discentes da educação profissional técnica de nível médio. Pretendo realizar a pesquisa principalmente por meio de observação das aulas de Psicologia Organizacional (curso de Administração); Psicologia Comportamental e Psicologia Social (curso de Marketing), bem como observações dos espaços comuns de convivência da escola. Tais observações serão complementadas por conversas formais e informais com docentes e discentes, bem como de outros funcionários da escola que quiserem contribuir para a pesquisa. As conversas formais poderão ou não ser gravadas em áudio, respeitando-se sua preferência. Farei uso de diário de campo para tomar notas durante as observações. Todo o material obtido durante a pesquisa será analisado em seu conjunto, e tanto o diário de campo quanto as possíveis conversas gravadas serão armazenadas em local reservado e sua identidade não será revelada. Você poderá, quando quiser, receber informações adicionais sobre o estudo. A sua participação é voluntária e pode ser interrompida a qualquer momento do estudo sem prejuízo algum a você, seus colegas e à instituição. Durante ou após o término da pesquisa, caso não queira mais que as informações que tenham sido obtidas com você ou que Ihe digam respeito sejam utilizadas, você poderá me contatar para destruição do material de registro. Os resultados da pesquisa serão divulgados em eventos e publicações científicas, em meios impressos e / ou eletrônicos, no sentido de contribuir para um maior conhecimento do tema estudado, bem como para a formação de professores de psicologia. Em todos os casos garanto seu anonimato.

Coloco-me a disposição pelo telefone (11) $6652-2443$ e endereço Av. Prof. Mello Moraes, 1721, Bloco A, sala 186, Cidade Universitária - São Paulo. O endereço do Comitê de Ética em Pesquisa com Seres Humanos do IPUSP é: Av. Prof. Mello Moraes, 1721, Bloco G, sala 22, Cidade Universitária - São Paulo, SP, fone (11) 3097-0529.

Diante do exposto, eu esclarecido (a) sobre a pesquisa a ser realizada por Angelina Pandita Pereira e não restando quaisquer dúvidas a respeito do lido e explicado, concordo em participar. Declaro ainda que este documento foi apresentado em duas vias, ficando uma comigo e outra com a pesquisadora.

São Paulo, __ de ___ de 2010.

Assinatura do participante

Assinatura da pesquisadora Angelina Pandita Pereira 
ANEXO A - Matriz curricular do curso de técnico em Administração

Centro Estadual de Educação Tecnológica Paula Souza

Governo do Estado de São Paulo
Praça Cel. Fernando Prestes, 74 - Bom Retiro - CEP: 01124-060 - São Paulo - SP

\section{EIXO TECNOLÓGICO: GESTÃO E NEGÓCIOS}

Habilitação Profissional Técnica de Nível Médio de TÉCNICO EM ADMINISTRAÇÃO(2,5)

\begin{tabular}{|c|c|c|c|}
\hline \multicolumn{4}{|l|}{ MÓDULO I } \\
\hline & T. & & $\begin{array}{l}\text { I. (h) } \\
\text { Total }\end{array}$ \\
\hline $\begin{array}{l}\text { I.1 Linguagem, Trabalho e } \\
\text { Tecnologia }\end{array}$ & & & 50 \\
\hline $\begin{array}{l}\text { I.2 Aplicativos Informatizados } \\
\text { da Administração }\end{array}$ & 25 & 25 & 50 \\
\hline $\begin{array}{l}\text { 1.3 Processos de Operações } \\
\text { Contábeis }\end{array}$ & 25 & 25 & 50 \\
\hline $\begin{array}{l}\text { 1.4 Métodos Quantitativos Aplicados } \\
\text { à Administracāo }\end{array}$ & 50 & 50 & 100 \\
\hline 1.5 Gestão Empresarial I & 50 & 50 & 100 \\
\hline 1.6 Psicologia Organizacional & 25 & 25 & 50 \\
\hline I.7 Ética e Cidadania Organizacional & 25 & 25 & 50 \\
\hline 1.8 Sistemas Econômicos & 25 & 25 & 50 \\
\hline TOTAL & 250 & 250 & 500 \\
\hline
\end{tabular}

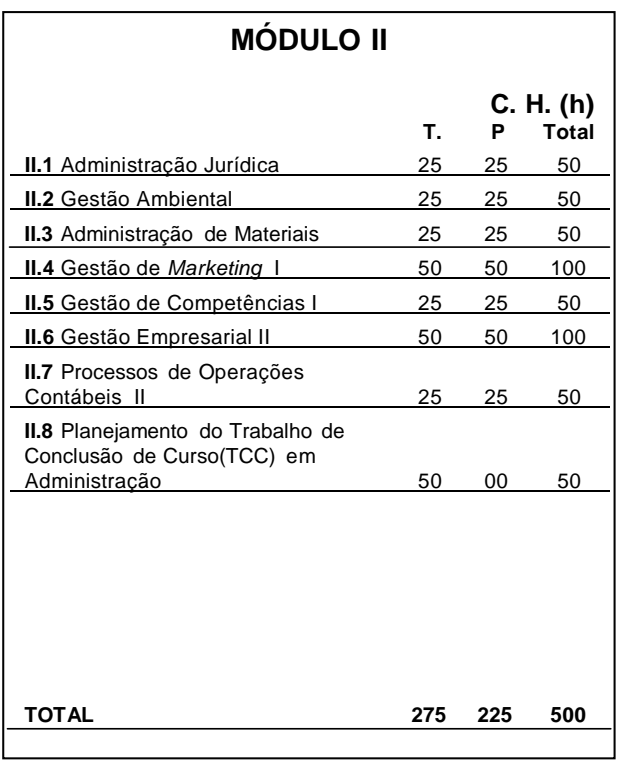

\begin{tabular}{|c|c|c|c|}
\hline \multicolumn{4}{|c|}{ MÓDULO III } \\
\hline & T. & & $\begin{array}{l}\text { H. (h) } \\
\text { Total }\end{array}$ \\
\hline Ill.1 Administração da Produção & 25 & 25 & 50 \\
\hline III.2 Gestão de Logística & 25 & 25 & 50 \\
\hline III.3 Gestão de Marketing II & 25 & 25 & 50 \\
\hline $\begin{array}{l}\text { III.4 Sistemas de Informações } \\
\text { Gerenciais }\end{array}$ & 25 & 25 & 50 \\
\hline III.5 Gestão de Competências II & 25 & 25 & 50 \\
\hline $\begin{array}{l}\text { III.6 Processos Financeiros e } \\
\text { Orçamentários }\end{array}$ & 25 & 25 & 50 \\
\hline $\begin{array}{l}\text { III.7 Criação e Desenvolvimento de } \\
\text { Empresas }\end{array}$ & 50 & 50 & 100 \\
\hline $\begin{array}{l}\text { III.8 Desenvolvimento do Trabalho } \\
\text { de Conclusão de Curso(TCC) em } \\
\text { Administração }\end{array}$ & 00 & 50 & 50 \\
\hline III.9 Inglês Instrumental & 25 & 25 & 50 \\
\hline TOTAL & 275 & 275 & 500 \\
\hline
\end{tabular}

MÓDULO I

SEM CERTIFICAÇÃO TÉCNICA

\section{MÓDULOS I + II}

Qualificacão Técnica de Nível Médio de ASSISTENTE ADMINISTRATIVO
MÓDULOS I + II + III

Habilitação Profissional Técnica de Nível Médio de TÉCNICO EM ADMINISTRAÇÃO 
ANEXO B - Matriz curricular do curso de técnico em Marketing

Centro Estadual de Educação Tecnológica Paula Souza

Praça Cel. Fernando Prestes, 74 Bom Retiro - CEP : 01124-060 - São Paulo - SP

EIXO TECNOLÓGICO: GESTÃo E NEGÓCIOS

Habilitação Profissional Técnica de Nível Médio de TÉCNICO EM MARKETING $(2,5)$

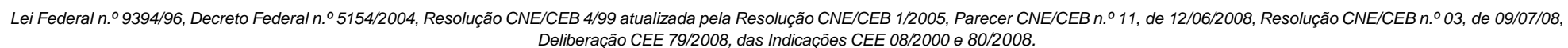

do Coordenador do Ensino Médio e Técnico n.․ 5, de 06/01/2009, publicada no DOE de 17/01/09, seção I, página 52.

\begin{tabular}{|c|c|c|c|}
\hline \multicolumn{4}{|c|}{ MÓDULO I - 1 Semestre de 2009} \\
\hline & \multicolumn{3}{|c|}{ C. H. (h-a) } \\
\hline l.1 - Administração de Marketing & $\begin{array}{r}\mathrm{T} \\
75\end{array}$ & $\begin{array}{r}\mathbf{P} \\
25\end{array}$ & $\begin{array}{l}\text { Tot } \\
100\end{array}$ \\
\hline $\begin{array}{l}1.2 \text { - Planejamento de Pronto de Vendas - } \\
\text { PDV }\end{array}$ & 35 & 15 & 50 \\
\hline I.3 - Planejamento Financeiro e Contábil & 35 & 15 & 50 \\
\hline I.4 - Legislação Tributária e Comercial & 35 & 15 & 50 \\
\hline 1.5 - Comunicação Mercadológica & 35 & 15 & 50 \\
\hline 1.6 - Ética e Cidadania Organizacional & 50 & 00 & 50 \\
\hline I.7- Espanhol Instrumental I & 50 & 00 & 50 \\
\hline $\begin{array}{l}\text { 1.8 - Aplicativos Informatizados em } \\
\text { Marketing }\end{array}$ & 00 & 50 & 50 \\
\hline 1.9 - Linguagem, Trabalho e Tecnologia & 50 & 00 & 50 \\
\hline TOTAL & 365 & 135 & 500 \\
\hline
\end{tabular}

MODULO I

SEM CERTIFICAÇÃO TÉCNICA

\begin{tabular}{|c|c|c|c|}
\hline \multicolumn{4}{|c|}{ MÓDULO II - 20 Semestre de 2009} \\
\hline & \multicolumn{3}{|c|}{ C. H. (h-a) } \\
\hline & & & \\
\hline Comunicação Mercadológica & 75 & 25 & 100 \\
\hline II.2 - Execução Financeira e Contábil & 35 & 15 & 50 \\
\hline $\begin{array}{l}\text { II.3 - Desenvolvimento de Ponto de Vendas - } \\
\text { PDV }\end{array}$ & 35 & 15 & 50 \\
\hline Il.4 - Psicologia Comportamental & 35 & 15 & 50 \\
\hline II.5 - Inglês Instrumental I & 50 & 00 & 50 \\
\hline II.6 - Espanhol Instrumental II & 50 & 00 & 50 \\
\hline II.7 - Informática Aplicada ao Marketing & 00 & 50 & 50 \\
\hline II.8 - Estratégias de Distribuição & 35 & 15 & 50 \\
\hline $\begin{array}{l}\text { II.9 - Planejamento do Trabalho de } \\
\text { Conclusão de Curso (TCC) em Marketing }\end{array}$ & 50 & 00 & 50 \\
\hline TOTAL & 365 & 135 & 500 \\
\hline
\end{tabular}

MÓDULOS I + II

Qualificação Técnica de Nível Médio de ASSISTENTE COMERCIAL
MÓDULO III - 10 Semestre de 2010

C. H. (h-a)

\begin{tabular}{lrrr} 
& T & P & Tot \\
\hline Ill.1 - Plano de Marketing & 75 & 25 & 100
\end{tabular}

$\begin{array}{llll}\text { III. } 2 \text { - Gerenciamento de Força de Venda } & 75 & 25 & 100\end{array}$

III.3 - Psicologia Social $\quad 35 \quad 15 \quad 50$

III.4 - Logística de Organização de Materiais $35 \quad 15 \quad 50$

III.5 - Comércio Exterior $\quad 35 \quad 15 \quad 50$

III.6 - Plano de Comunicação

$35 \quad 15 \quad 50$

III.7 - Desenvolvimento do Trabalho de

$00 \quad 50 \quad 50$

III.8 - Inglês Instrumental II $\quad 35 \quad 15 \quad 50$

TOTAL

$325 \quad 175 \quad 500$

MÓDULOS I + II + III

Habilitação Profissional Técnica de Nível Médio de TÉCNICO EM MARKETING 